Национальный институт профессиональных бухгалтеров, финансовых менеджеров и экономистов

Серия «Административная и бюджетная реформы на современном этапе» Выпуск 10

\author{
Д.А. Яковенко
}

\title{
ОТДЕЛЬНЫЕ ВОПРОСЫ КОНТРОЛЯ В ЭКОЛОГИИ: ОПЫТ, ПРОБЛЕМЫ И ПЕРСПЕКТИВЫ
}




\section{Яковенко Д.А.}

947 Отдельные вопросы контроля в экологии: опыт, проблемы и перспективы / Д.А. Яковенко - Самара, Национальный ин-т проф. бухгалтеров, финансовых менеджеров и экономистов, 2021. - 291 с. (Серия «Административная и бюджетная реформы на современном этапе»; Вып.10) ISBN 978-5-94928-020-1

Благоприятное состояние окружающей среды - одна из составляющих, позволяющих государству иметь необходимую основу государственного и общественного развития, стабильность в вопросах сохранения конституционного строя, суверенитета и территориальной целостности.

Экологическая безопасность Российской Федерации является составной частью ее национальной безопасности в целом, ориентирована на реализацию осуществляемых в Российской Федерации экологических преобразований.

Реализация функции обеспечения безопасности, защиты жизни и здоровья людей, охраны здоровья граждан и окружающей среды, природных ресурсов, возложена на государство в соответствии с Конституцией. В настоящее время в сфере экологии в России имеется достаточно разветвленная система контроля и надзора как со стороны органов государственной власти и местного самоуправления, так и негосударственная, в том числе общественная. Наличие развитой и разветвленной системы контроля и надзора, однако, не дает гарантию ее эффективности.

Среди имеющихся проблем, автор отмечает, что предусмотренная законодательством обязательная государственная экспертиза начинаемой вновь деятельности далеко не всегда реализуется на практике, отсутствует устанавливаемый регламентамипорядок межведомственного взаимодействия по закреплению обязательности проведения государственной экологической экспертизы.

Несмотря на то, что экологический аудит как институт существует в России более 25 лет, до сих пор отсутствует Федеральный закон, регулирующий данные правоотношения, нет стандартов аудиторской деятельности в сфере экологии, отсутствует даже кодекс профессиональной этики экологического аудитора, не узаконены случаи обязательного проведения экологического аудита.

В России в настоящее время отсутствует системная государственная поддержка проектов так называемого устойчивого развития (в том числе «зеленых» проектов, отсутствует как государственный так и общественный резонанс в отношении публичной экологической отчетности компаний, что, безусловно, снижает заинтересованность бизнеса в раскрытии информации о социально-экологических инициативах и проектах.

Жизнь ставит задачу первоочередного решения экологических проблем. Это главный современный вызов всему человечеству. бухгалтеров, финансовых менеджеров и экономистов (оформление), 2021 


\section{Dmitry A. Yakovenko. Environmental control issues: experience, problems and prospects}

Series: Administrative and budget reforms at the present stage. Issue 10. - Samara, The Institute of Professional Accountants of Samara Region, 2021, page 291.

The good condition of the environment is one of the essentials enabling the state to have the necessary basis for state and social development, stability in questions of constitutional order, national sovereignty, and territorial integrity protection.

The environmental security of the Russian Federation is an integral part of its national security in general and it is centering on the implementation of environmental reforms in the Russian Federation.

In accordance with the Constitution, the state is responsible for the safeguarding of human life and health, the protection of public health as well as the environment and natural resources. At present in the environment area in Russia, there is quite an extensive system of control and supervision by state authorities and local governments, as well as a non-state system of control, including public control. The presence of a well-developed and extensive system of control and supervision, however, does not guarantee its effectiveness.

Among the existing problems, the author notes that the mandatory state expert review of new business activities, stipulated by the legislation, is not always implemented in practice, there is no procedure for interdepartmental interaction to enshrine the mandatory implementation of state environmental expert review, established by the regulations.

Even thoughthe fact that the environmental audit as an institution exists in Russia for over 25 years, there is still no federal law regulating these legal relations, there are no standards of auditing activities in the environmental area, there is not even a code of ethics of environmental auditor, the cases of mandatory environmental audits are not legalized.

At the moment there is no systematic state support for so-called sustainable development projects (including "green" projects) in the Russian Federation, there is no state and public response to public environmental reporting by companies, which certainly reduces the interest of business in disclosing information about social and environmental initiatives and projects.

Life sets the task of solving environmental problems as a priority. This is the major modern challenge for all mankind. 


\section{ОГЛАВЛЕНИЕ}

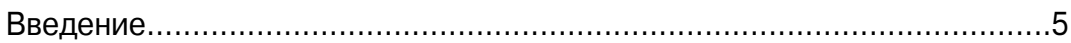

ГЛАВА 1. Экологическая экспертиза.................................................11

1.1. Правовое регулирование экологической экспертизы....................11

1.2. Понятие, предмет и принципы экологической экспертизы...........27

1.3. Виды экологической экспертизы.............................................31

1.4. Объекты экологической экспертизы.........................................32

1.5. Субъекты экологической экспертизы........................................59

1.6. Порядок проведения экологической экспертизы.........................94

1.6.1. Общий порядок..........................................................94

1.6.2. Особенности порядка проведения государственной экологической экспертизы объектов, указанных в пунктах 7.1 и 7.3 статьи 11; пункте 4.1 статьи 12 Закона № 174-ФЗ...........................99 1.6.3. Порядок проведения общественной экологической экспертизы...................................................102

1.7. Результаты проведения экологической экспертизы..................104

1.7.1. Результаты экспертизы, проведенной в обычном порядке....104

1.7.2. Результаты общественной экологической экспертизы.........107

1.8. Ответственность за нарушение требований

в области экологической экспертизы........................................110

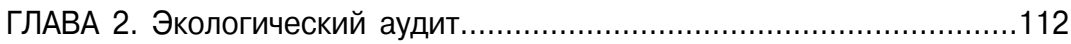

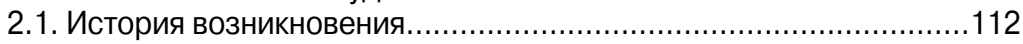

2.2. Правовое регулирование экологического аудита.........................117

2.3. Понятие, предмет и принципы экологического аудита.................126

2.4. Виды экологического аудита...................................................131

2.5. Объекты экологического аудита............................................139

2.6. Субъекты экологического аудита..............................................140

2.7. Порядок проведения экологического аудита............................142

2.8. Результаты проведения экологического аудита.........................157

ГЛАВА 3. Концепция устойчивого развития,

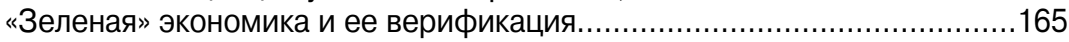

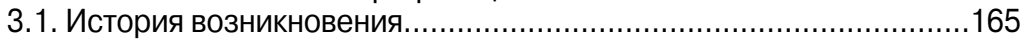

3.2. Верификация «зеленой» экономики.......................................169

3.3. Верификация производных финансовых инструментов

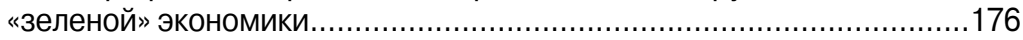

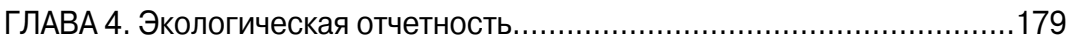

4.1. Публичная социально-экологическая отчетность компаний и дополнительная информация, включаемая в финансовую отчетность....179

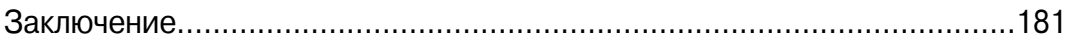

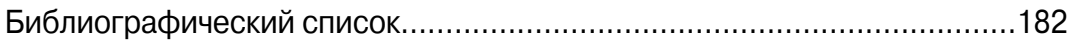

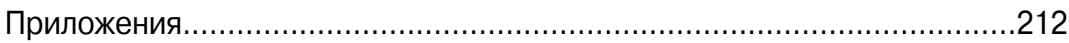




\section{ВВЕДЕНИЕ}

Благоприятное состояние окружающей среды - одна из составляющих, позволяющих государству иметь необходимую основу государственного и общественного развития, стабильность в вопросах сохранения конституционного строя, суверенитета и территориальной целостности.

Экологическая безопасность Российской Федерации является составной частью ее национальной безопасности в целом, ориентирована на реализацию осуществляемых в Российской Федерации экологических преобразований.

Государственная политика в области охраны окружающей среды определяется в Конституции Российской Федерации (далее - Конституция) и преследует следующие цели:

- сохранение важнейшей основы жизни и деятельности народов Российской Федерации, в качестве которой выступают земля и иные природные ресурсы (часть 1 статьи $9^{1}$ );

- осуществление владения, пользования и распоряжения землей и другими природными ресурсами их собственниками свободно, если это не наносит ущерба окружающей среде и не нарушает прав и законных интересов иных лиц (часть 2 статьи 36);

- поощрение деятельности, способствующей укреплению здоровья человека, развитию физической культуры и спорта, экологическому и санитарно-эпидемиологическому благополучию (часть 2 статьи 41);

- обеспечение конституционного права на благоприятную окружающую среду (статья 42);

- охрана природы и окружающей среды, бережное отношение к природным богатствам (статья 58);

- обеспечение проведения в Российской Федерации единой государственной политики в области культуры, науки, образования, здравоохранения, социального обеспечения, охраны окружающей среды (пункт «В» части 1 статьи 114).

Указанные конституционные нормы направлены в конечном итоге на обеспечение жизненно важных интересов человека и общества в сфере экологической безопасности.

Значительную роль в обеспечении экологических интересов общества, направленных на реализацию права каждого на благоприятную окружающую среду, играет государство (статья 42).

\footnotetext{
${ }^{1}$ Здесь и далее по тексту - ссылки на Конституцию.
} 
Реализация функции обеспечения безопасности, защиты жизни и здоровья людей, охраны здоровья граждан и окружающей среды, природных ресурсов, возложенная на государство в соответствии с Конституцией, осуществляется государственными органами на основе конституционных положений о свободе предпринимательской деятельности, о недопустимости установления препятствий для свободного перемещения товаров, услуг и финансовых средств.

В соответствии со статьей 42 Конституции каждый имеет право на благоприятную окружающую среду, достоверную информацию о ее состоянии и на возмещение ущерба, причиненного его здоровью или имуществу экологическим правонарушением. Статья 58 Конституции устанавливает обязанность сохранять природу и окружающую среду, бережно относиться к природным богатствам. Во многих странах, в том числе и в России, в результате нарастающей озабоченности общества состоянием окружающей среды, нехватки достоверной информации в этой области начал развиваться такой вид услуг, как экологический аудит. Рассматриваемый вид аудита способствует повышению конкурентоспособности и рентабельности продукции аудируемого предприятия с позиции роста экономической эффективности его хозяйственной, и в том числе природоохранной, деятельности, дает возможность правильно сформировать учетную политику организации, способствует эффективному решению вопросов льготного налогообложения при внедрении ресурсосберегающих технологий, предотвращению возможных производственных аварий.

Вопросы экологии и защиты окружающей среды стояли на повестке дня еще до распада СССР.

В статье 3 закона РСФСР «Об охране окружающей природной среды»² (далее - Закон № 2060-1) было установлено, что при осуществлении хозяйственной, управленческой и иной деятельности, оказывающей отрицательное воздействие на состояние окружающей природной среды, государственные органы, предприятия, учреждения, организации, а также граждане Российской Федерации обязаны руководствоваться следующими основными принципами:

приоритетом охраны жизни и здоровья человека, обеспечения благоприятных экологических условий для жизни, труда и отдыха населения;

научно обоснованным сочетанием экологических и экономических интересов общества, обеспечивающих реальные гарантии прав человека на здоровую и благоприятную для жизни окружающую природную среду;

соблюдением требований природоохранительного законодательства, неотвратимостью наступления ответственности за их нарушения;

${ }^{2}$ Закон РСФСР от 19.12.1991 № 2060-1 «Об охране окружающей природной среды». 
международным сотрудничеством в охране окружающей природной среды.

Статья 13 Закона № 2060-1 предусматривала возможность создания общественных объединений граждан в целях защиты и охраны окружающей среды, в том числе рекомендовать своих представителей для участия в государственной экологической экспертизе по вопросам размещения и проектирования объектов, проводить общественную экологическую экспертизу.

В статьях 19 и 20 Закона № 2060-1 были установлены понятия:

- лимитов на природопользование - системы экологических ограничений по территориям устанавливаемых предприятиям - природопользователям на определенный срок (объемы предельного использования (изъятия) природных ресурсов, выбросов и сбросов загрязняющих веществ в окружающую природную среду и размещения отходов производства);

- платности природопользования, которая включала плату за природные ресурсы, за загрязнение окружающей природной среды и за другие виды воздействия.

Автор отдельно подчеркивает, что ряд регламентирующих документов, действующих в настоящее время, принимались еще в СССР. Экологические стандарты в развитых странах за это время существенно изменились и приведенные ниже документы нуждаются в инвентаризации, а, возможно, и в пересмотре:

- «ОНД 1-84. Инструкция о порядке рассмотрения, согласования и экспертизы воздухоохранных мероприятий и выдачи разрешений на выброс загрязняющих веществ в атмосферу по проектным решениям» (утв. Госкомгидрометом СССР 23.04.1984, Согласована Госстроем СССР 19.04.1984 № BA 1878 20);

- «Предельное содержание токсичных соединений в промышленных отходах в накопителях, расположенных вне территории предприятия (организации)» (утв. Главным государственным санитарным врачом СССР 19.11.1985 № 4015-85, Госкомгидрометом СССР 19.11.1985, Минводхозом СССР 15.11.1985, Мингеологии СССР 18.07.1985, Минсельхозом СССР 19.06.1985);

- «РД-17-86. Методические указания по расчету валовых выбросов вредных веществ в атмосферу для предприятий нефтепереработки и нефтехимии» (утв. Миннефтехимпромом СССР 17.02.1987);

- «Рекомендации по оформлению и содержанию проекта нормативов предельно допустимых выбросов в атмосферу (ПДВ) для предприятия» (утв. Госкомгидрометом СССР 28.08.1987);

- «Инструкция по инвентаризации выбросов загрязняющих веществ в атмосферу» (утв. Госкомприроды СССР, 1990).

В настоящее время в сфере экологии в России имеется достаточно 


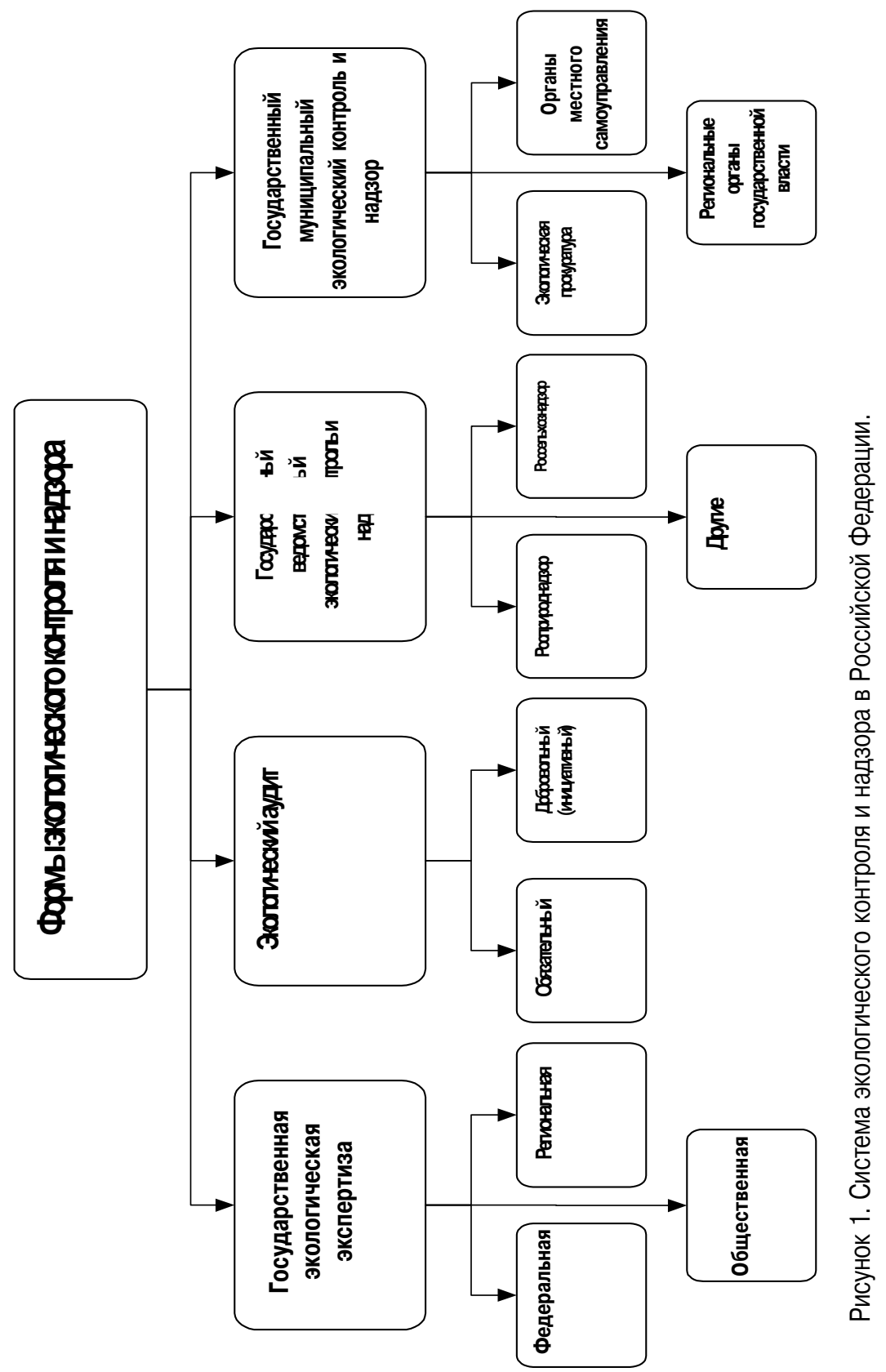


разветвленная система контроля и надзора как со стороны органов государственной власти и местного самоуправления, так и негосударственная, в том числе общественная (См.: Рисунок 1). Наличие развитой и разветвленной системы контроля и надзора, однако, не дает гарантию ее эффективности.

Автор отмечает, что по временному признаку контроль и надзор, осуществляемый различными органами и организациями, подразделяется на предварительный, текущий и последующий. При этом текущий и последующий контроль как с точки зрения субъектного состава уполномоченных органов и организаций, так и с точки зрения методологического обеспечения, не имеют существенных различий.

Среди имеющихся проблем, автор отмечает, что предусмотренная законодательством обязательная государственная экспертиза начинаемой вновь деятельности далеко не всегда реализуется на практике. Созданный более 25 лет назад институт экологического аудита и до сих пор находится в зачаточном состоянии. Попытки создать систему верификации предпринимались в России в 1995 году, но на тот момент так и не были реализованы. Саму систему верификации автор рассматривает как систему, аналогичную технологическому добровольному (инициативному) аудиту.

Публичная экологическая (социально-экологическая) отчетность крупных компаний только начинает внедряться.

Механизм реализации контрольно-надзорных полномочий, осуществляемых в рамках ведомственного экологического контроля и надзора, осуществляемый специализированной службой Министерства сельского хозяйства Российской Федерации - Россельхознадзором, подведомственными Министерству природных ресурсов и экологии Российской Федерации органами:

- Федеральная служба по надзору в сфере природопользования;

- Федеральное агентство по недропользованию;

- Федеральное агентство водных ресурсов;

- Федеральная служба по гидрометеорологии и мониторингу окружающей среды;

- Федеральное агентство лесного хозяйства

и некоторыми другими уполномоченными органами имеет хорошую методологическую базу.

Надзорные полномочия, осуществляемые специализированными органами Генеральной прокуратуры Российской Федерации - природоохранной прокуратурой, также методологической базой обеспечены.

Но в методологическом обеспечении системы текущего и последующего экологического контроля, осуществляемого органами местного самоуправления и органами государственной власти субъектов Российской Федерации, по мнению автора, имеются существенные пробелы. 
Исходя из изложенного, автор в данной монографии остановился на рассмотрении некоторых вопросов: экологической экспертизы, экологического аудита, верификации «зеленых» проектов и внедрении публичной экологической (социально-экологической) отчетности компаний.

Несмотря на то, что экологический аудит как институт существует в России более 25 лет, до сих пор отсутствует Федеральный закон, регулирующий данные правоотношения, нет стандартов аудиторской деятельности в сфере экологии, отсутствует даже кодекс профессиональной этики экологического аудитора, не узаконены случаи обязательного проведения экологического аудита.

На начальном этапе к аттестации на экологических аудиторов допускались претенденты, не имеющие не только высшего профильного, но и вообще высшего образования. Действующие документы по регулированию деятельности в сфере экологического аудита в части требования о лицензировании этого вида деятельности противоречат законодательству Российской Федерации.

В России в настоящее время отсутствует системная государственная поддержка проектов так называемого устойчивого развития (в том числе «зеленых» проектов, отсутствует как государственный так и общественный резонанс в отношении публичной экологической отчетности компаний, что, безусловно, снижает заинтересованность бизнеса в раскрытии информации о социально-экологических инициативах и проектах.

Данная монография ставит перед собой цель систематизировать имеющиеся данные по перечисленным проблемам и предложить некоторые пути решения проблем. 


\section{ГЛАВА 1. Экологическая экспертиза}

\section{1. Правовое регулирование экологической экспертизы}

Впервые в России принципы и правила государственной экологической экспертизы были установлены в статьях 35-39 Закона № 2060-1:

- государственная экологическая экспертиза осуществляется на принципах обязательности ее проведения, научной обоснованности и законности ее выводов, независимости, вневедомственности в организации и проведении, широкой гласности и участия общественности;

- государственной экологической экспертизе подлежат все предплановые, предпроектные и проектные материалы по объектам и мероприятиям, намечаемым к реализации на территории Российской Федерации, независимо от их сметной стоимости и принадлежности, а также экологические обоснования лицензий и сертификатов.

К разновидности государственной экологической экспертизы была отнесена общественная экспертиза.

В рамках реализации полномочий по осуществлению государственной экологической экспертизы были изданы:

- постановление Правительства Российской Федерации от 22.09.1993 № 942 «Об утверждении Положения о государственной экологической экспертизе»;

- постановление Правительства Российской Федерации от 11.06.1996 № 698 «Об утверждении Положения о порядке проведения Государственной экологической экспертизы» (далее - Постановление № 698)3;

- приказ Минприроды РФ от 29.12.1995 № 539 «Об утверждении «Инструкции по экологическому обоснованию хозяйственной и иной деятельности» (далее - Приказ № 539);

- приказ Минприроды РФ от 13.08.1996 №362 «О выполнении постановления Правительства Российской Федерации от 11.06.1996. №698 «Об утверждении Положения о порядке проведения государственной экологической экспертизы»;

- приказ Минприроды РФ от 28.09.1995 №392 «Об утверждении единой формы Заключения государственной экологической экспертизы».

В соответствии с пунктом 1.5. Инструкции, утвержденной Приказом №

${ }^{3}$ Документ утратил силу с 1 января 2021 года в связи с изданием Постановления Правительства РФ от 18.09.2020 № 1496. 
539, экологически и экономически обоснованные решения инициаторов хозяйственной и иной деятельности в документации должны гарантировать:

\section{экологическую безопасность населения;}

минимальный ущерб природной среде и населению при устойчивом социально-экономическом развитии территорий;

благоприятные экологические условия для проживания населения;

рациональное и экономное расходование природных, материальных, топливно-энергетических и трудовых ресурсов;

выпуск экологически безопасной продукции;

сохранение биологического разнообразия, чистоты воздуха, источников водоснабжения и других природных объектов, исторического наследия народа;

внедрение высокопроизводительного мало- или безотходного технологического оборудования и техники.

Прединвестиционная документация должна содержать информацию, достаточную для определения экологического риска намечаемой деятельности, оценки рациональности природопользования при различных вариантах этой деятельности (пункт 4.1 Инструкции, утвержденной Приказом № 539).

Материалы по экологическому обоснованию проектных решений должны быть достаточными для оценки:

прогнозируемого воздействия планируемой деятельности на окружающую среду;

рациональности использования природных ресурсов;

прогрессивности технологических решений при строительстве и эксплуатации объекта;

уровня экологической опасности применяемой и производимой продукции, а также отходов производства, возможности их размещения;

оптимальности выбранных мероприятий по охране природы и сохранению историко-культурного наследия, их эффективности и достаточности;

ущерба природной среде и населению (пункт 6.11 Инструкции, утвержденной Приказом № 539).

Пунктом 4 Постановления № 698 было установлено, что перечень материалов, представляемых на государственную экологическую экспертизу, определяется нормативными актами Минприроды РФ.

В настоящее время вопросы проведения государственной экологической экспертизы регламентируются постановлением Правительства Российской Федерации от 07.11.2020 № 1796 «Об утверждении Положения о проведении государственной экологической экспертизы» (далее - Положения о проведении государственной экологической экспертизы). В пункте 3 Положения о проведении государственной экологической экспертизы определен орган, наделенный этими полномочиями: Федеральная служба по надзору в сфере природопользования (ее территориальные органы). 
Таким образом, мы можем утверждать, что в Российской Федерации система предварительного экологического контроля в форме государственной экологической экспертизы начала создаваться в 90-е годы.

Она включает в себя государственный контроль и надзор и участие общественности в осуществлении контрольных мероприятий.

Начальная стадия этого контроля обозначена в Федеральном законе от 23.11.1995 № 174-ФЗ «Об экологической экспертизе» (далее - Закон № 174-ФЗ). Принципиальными в этом виде контроля (экологической экспертизе) являются следующие моменты:

- государственная экологическая экспертиза является обязательной до принятия решения о реализации объекта (строительства, создания чего-то нового: от детской площадки, до завода по переработки мусора, и др.);

- экологическая экспертиза исходит из презумпции потенциальной экологической опасности для любой намечаемой хозяйственной и иной деятельности.

Закон № 174-ФЗ так же, как и ранее Закон № 2060-1 предусматривает как государственную экологическую экспертизу (выполняемую на федеральном или региональном уровне, в зависимости от значимости намечаемой хозяйственной деятельности), так и общественную экологическую экспертизу.

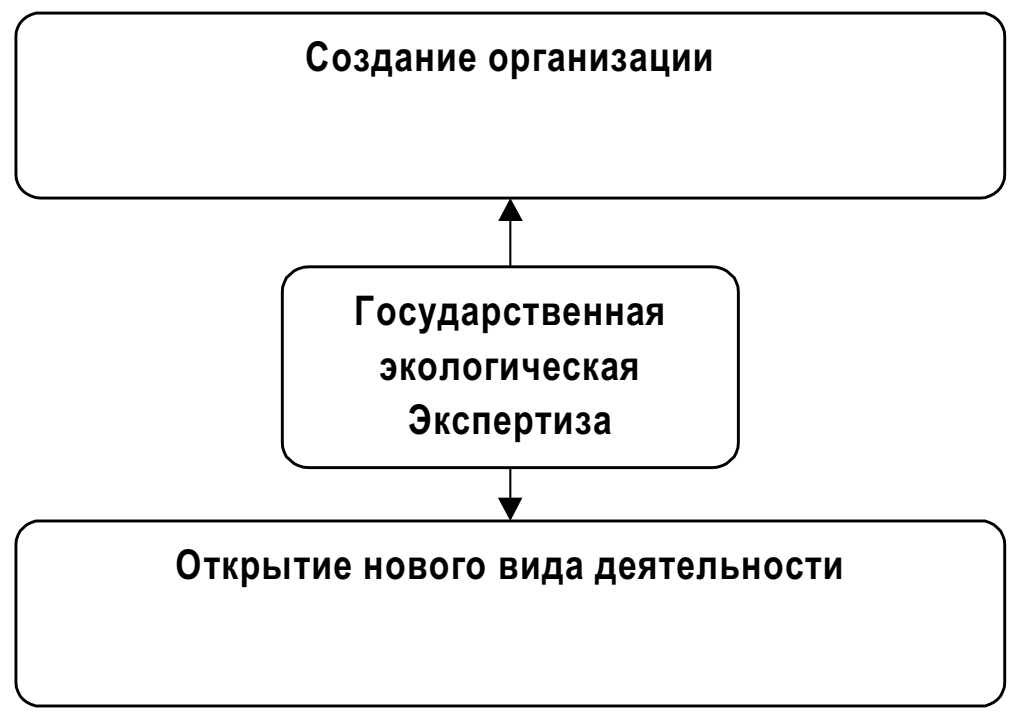

Рисунок 2. Место государственной экологической экспертизы при создании новой организации и (или) открытию нового вида деятельности. 
Принимая во внимание, что в силу требований статьи 72 Конституции законодательство об охране окружающей среды относится к совместному ведению Российской Федерации и ее субъектов, в статье 2 Закона № 174ФЗ определено, что законодательство об экологической экспертизе основывается на положениях Конституции, Федерального закона Российской Федерации от 10.01.2002 № 7-Ф3 «Об охране окружающей среды» (далее - Закона № 7-Ф3) и состоит из Закона № 174-ФЗ, принимаемых в соответствии с ним законов и иных нормативных правовых актов Российской Федерации, а также законов и иных нормативных правовых актов субъектов Российской Федерации.

Общим законом, определяющим основные принципы охраны окружающей среды, является Закон № 7-ФЗ. Специальным законом, регламентирующим отношения в области экологической экспертизы, направленным на реализацию конституционного права граждан Российской Федерации на благоприятную окружающую среду посредством предупреждения негативных воздействий хозяйственной и иной деятельности на окружающую среду, является Закон№ 174-ФЗ.

Кроме того, к основным нормативным правовым актам федерального уровня, регламентировавшим ранее и (или) регламентирующим в настоящее время отношения в области экологической экспертизы, можно отнести:

- Федеральный закон от 29.12.2014 № 473-Ф3 «О территориях опережающего социально-экономического развития в Российской Федерации", где в статье 27 определены особенности проведения государственной экологической экспертизы проектной документации объектов инфраструктуры территории опережающего социально-экономического развития;

- Федеральный закон от 07.06.2013 № 108-Ф3 «О подготовке и проведении в Российской Федерации чемпионата мира по футболу FIFA 2018 года, Кубка конфедераций FIFA 2017 года и внесении изменений в отдельные законодательные акты Российской Федерации» (статьи 27, 29);

- Федеральный закон от 19.07.2011 № 246-Ф3 «Об искусственных земельных участках, созданных на водных объектах, находящихся в федеральной собственности, и о внесении изменений в отдельные законодательные акты Российской Федерации", где в части 4 статьи 10 установлено, что проектная документация искусственного земельного участка подлежит государственной экологической экспертизе;

- Федеральный закон от 08.05.2009 № 93-Ф3 «Об организации проведения встречи глав государств и правительств стран - участников форума «Азиатско-тихоокеанское экономическое сотрудничество» в 2012 году, о развитии города Владивостока как центра международного сотрудничества в Азиатско-Тихоокеанском регионе и о внесении изменений в отдельные законодательные акты Российской Федерации» (статьи 4, 5); 
- Федеральный закон от 01.12.2007 № 310-Ф3 «Об организации и о проведении XXII Олимпийских зимних игр и XI Паралимпийских зимних игр 2014 года в городе Сочи, развитии города Сочи как горноклиматического курорта и внесении изменений в отдельные законодательные акты Российской Федерации» (статья 14);

- Градостроительный кодекс Российской Федерации (статьи 49, 51);

- Федеральный закон от 10.07.2001 № 92-Ф3 «О специальных экологических программах реабилитации радиационно загрязненных участков территории", где в части 2 статьи 5 установлено, что государственной экологической экспертизе в обязательном порядке подлежит единый проект, предусматривающий осуществление внешнеторговой сделки, связанной с ввозом в Российскую Федерацию облученных тепловыделяющих сборок ядерных реакторов из иностранных государств, и реализацию специальной экологической программы или программ, финансирование которых осуществляется за счет средств, полученных от указанной внешнеторговой сделки;

- Федеральный закон от 01.05.1999 № 94-Ф3 «Об охране озера Байкал», где в статье 5 и части 2 статьи 6 установлены обязательность государственной экологической экспертизы любой осуществляемой на Байкальской природной территории деятельности и запрет строительства новых хозяйственных объектов, реконструкции действующих хозяйственных объектов без положительного заключения государственной экологической экспертизы проектной документации таких объектов;

- Федеральный закон от 17.12.1998 № 191-Ф3 «Об исключительной экономической зоне Российской Федерации»;

- Федеральный закон от 31.07.1998 № 155-Ф3 «О внутренних морских водах, территориальном море и прилежащей зоне Российской Федерации»;

- Федеральный закон от 19.07.1997 № 109-Ф3 «О безопасном обращении с пестицидами и агрохимикатами»;

- Федеральный закон от 30.11.1995 № 187-Ф3 «О континентальном шельфе Российской Федерации»;

- Федеральный закон от 24.04.1995 № 52-Ф3 «О животном мире»;

- постановление Правительства Российской Федерации от 07.11.2008 № 822 «Об утверждении Правил представления проектной документации объектов, строительство, реконструкцию, капитальный ремонт которых предполагается осуществлять на землях особо охраняемых природных территорий, для проведения государственной экспертизы и государственной экологической экспертизы»;

- постановление Правительства Российской Федерации от 22.09.1993 № 942 «Об утверждении Положения о государственной экологической экспертизе»; 
- приказ Минприроды России от 12.05.2014 № 205 «Об утверждении Порядка определения сметы расходов на проведение государственной экологической экспертизы»;

- приказ Минприроды России от 06.05.2014 № 204 «Об утверждении Административного регламента Федеральной службы по надзору в сфере природопользования по предоставлению государственной услуги по организации и проведению государственной экологической экспертизы федерального уровня»;

- приказ Минприроды РФ от 23.09.2013 № 404 «Об утверждении Порядка оплаты труда внештатных экспертов государственной экологической экспертизы»;

- приказ Минприроды РФ от 29.06.2012 № 190 «Об утверждении Административного регламента Федеральной службы по надзору в сфере природопользования по исполнению государственной функции по контролю и надзору за полнотой и качеством осуществления органами государственной власти субъектов Российской Федерации переданных полномочий в области государственной экологической экспертизы с правом направления предписаний об устранении выявленных нарушений, а также о привлечении к ответственности должностных лиц, исполняющих обязанности по осуществлению переданных полномочий»;

- приказ Росрыболовства от 09.03.2010 № 158 «Об утверждении Административного регламента Федерального агентства по рыболовству по исполнению государственной функции по разработке и представлению на государственную экологическую экспертизу, а также определение и утверждение ежегодно общих допустимых уловов водных биологических ресурсов во внутренних водах Российской Федерации, в том числе во внутренних морских водах Российской Федерации, а также в территориальном море Российской Федерации, на континентальном шельфе и в исключительной экономической зоне Российской Федерации, в Азовском и Каспийском морях»;

- приказ Минприроды РФ от 22.07.2011 № 645 «Об утверждении форм и содержания представления отчетности об осуществлении органами государственной власти субъектов Российской Федерации переданных полномочий Российской Федерации в области экологической экспертизы»;

- приказ Минприроды РФ от 30.10.2008 № 273 «Об утверждении Административного регламента исполнения Министерством природных ресурсов и экологии Российской Федерации государственной функции по надзору за правовым регулированием органами государственной власти субъектов Российской Федерации вопросов осуществления переданных полномочий Российской Федерации в области водных отношений, государственной экологической экспертизы, объектов животного мира и среды их обитания, охоты и сохранения охотничьих ресурсов с правом направле- 
ния обязательных для исполнения предписаний об отмене нормативных правовых актов субъектов Российской Федерации или о внесении в них изменений»;

- приказ Госкомэкологии РФ от 16.05.2000 № 372 «Об утверждении Положения об оценке воздействия намечаемой хозяйственной и иной деятельности на окружающую среду в Российской Федерации»;

- приказ Минприроды России от 01.12.2020 № 999 «Об утверждении требований к материалам оценки воздействия на окружающую среду» и др.

Подводя итог, можно отметить следующее:

1. Помимо нормативных правовых актов федерального уровня, отношения в области экологической экспертизы регламентируются нормативными правовыми актами регионального уровня. При этом отмечается достаточно широкий перечень нормативных правовых актов федерального уровня разноотраслевого характера и отсутствие единых методологических подходов к формированию актов регионального уровня.

Как серьезную проблему автор отмечает, что ни в Федеральном законе от 08.08.2001 № 129-Ф3 «О государственной регистрации юридических лиц и индивидуальных предпринимателей», ни в иных правовых актах, определяющих порядок государственной регистрации юридических лиц и предпринимателей, не установлена связь факта представления документов на государственную регистрацию, осуществляемую уполномоченным органом государственной власти, с прохождением государственной экологической экспертизы. По мнению автора, именно отсутствие в составе представляемых на государственную регистрацию пакета документов сведений о прохождении государственной экологической экспертизы, создало ситуацию, когда значительная часть новых производств, избегает этой обязанности.

Объектный состав государственной экологической экспертизы, по мнению автора, также нуждается в уточнении и расширении перечня объектов.

2. В систему законодательства об экологической экспертизе входят не только нормативные правовые акты, определяющие порядок проведения указанного вида экспертизы, но и нормативные правовые акты, регламентирующие вопросы распределения полномочий в области экологической экспертизы между органами государственной власти разных уровней.

3. Законодательство об экологической экспертизе включает в себя правовые акты, принятые в разные периоды времени, некоторые из которых в силу объективных причин либо утратили свою актуальность, однако продолжают находиться в статусе действующих документов, либо не проходили процедуру регистрации в Минюсте РФ:

приказ Минприроды РФ от 28.03.1996 № 113 «Об утверждении Требований к материалам, представляемым на государственную экологическую 


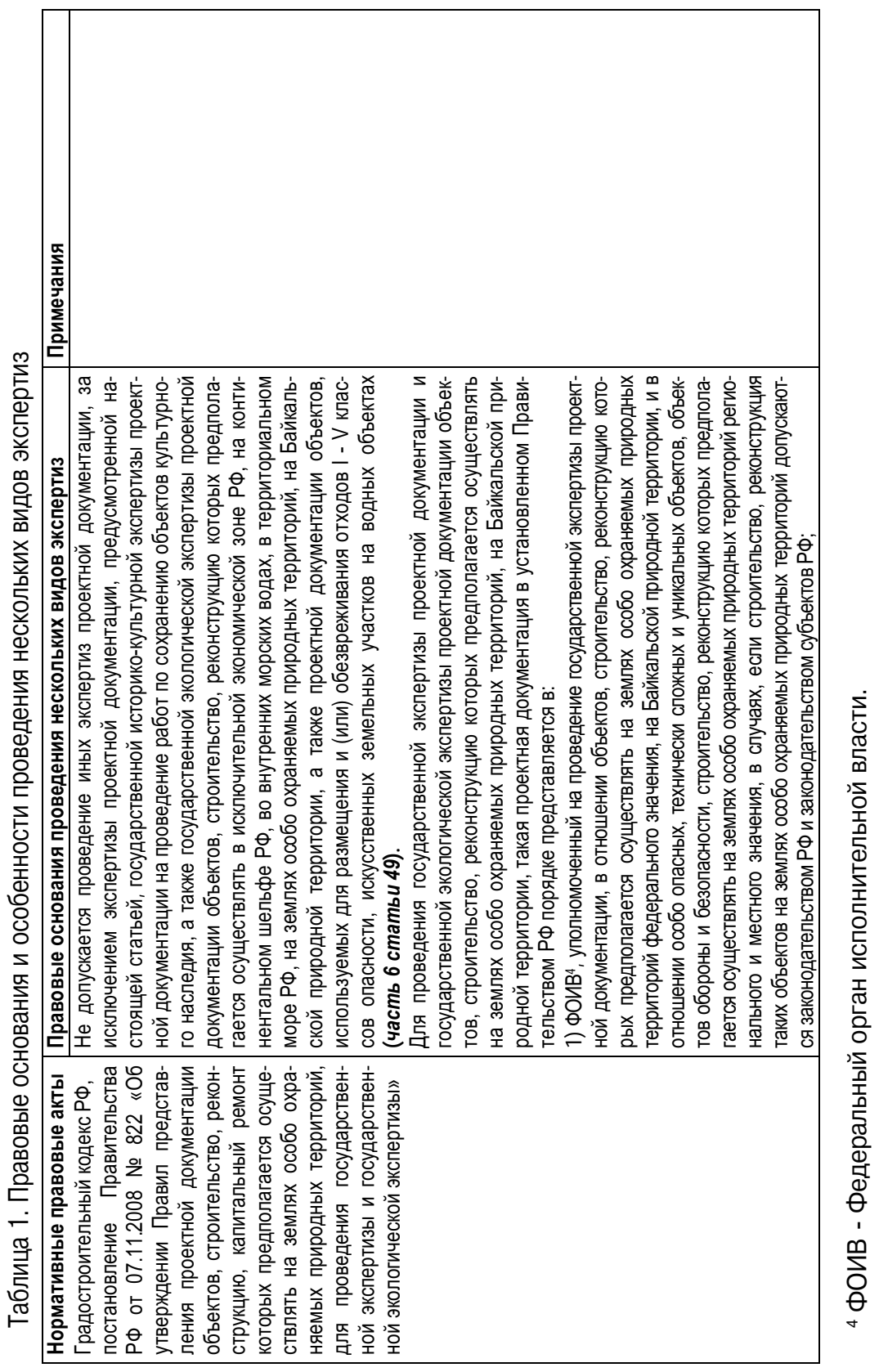




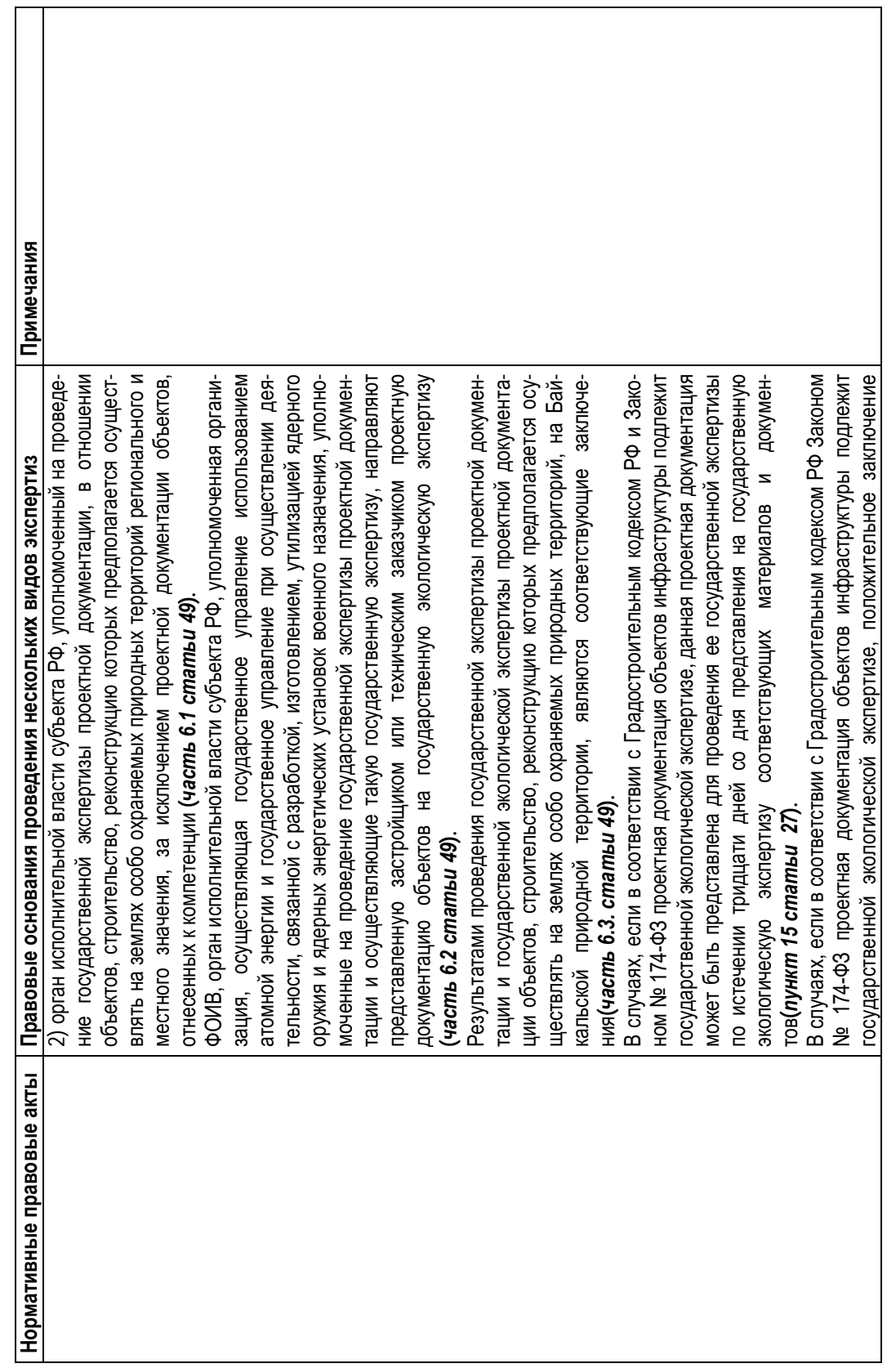




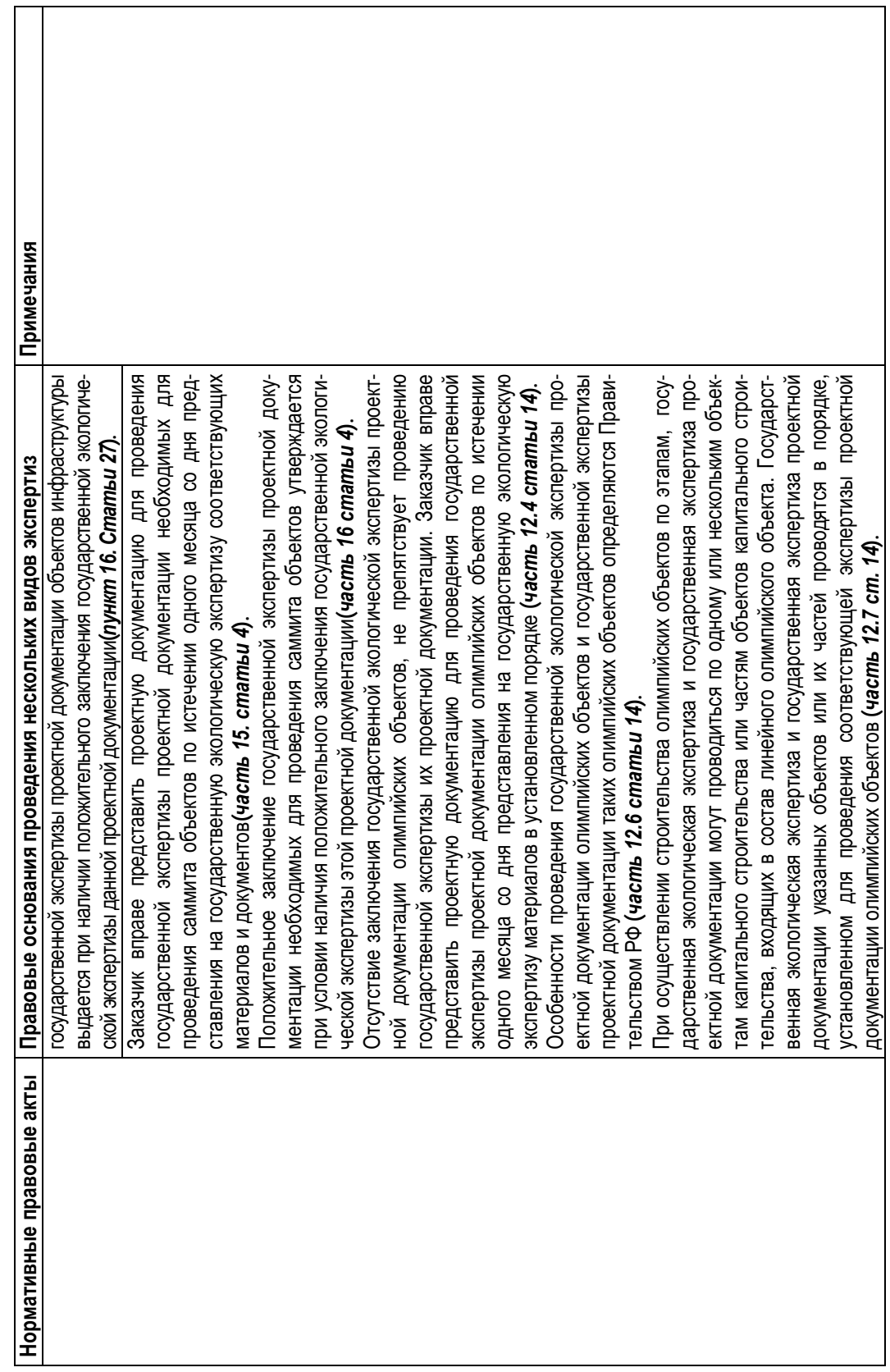




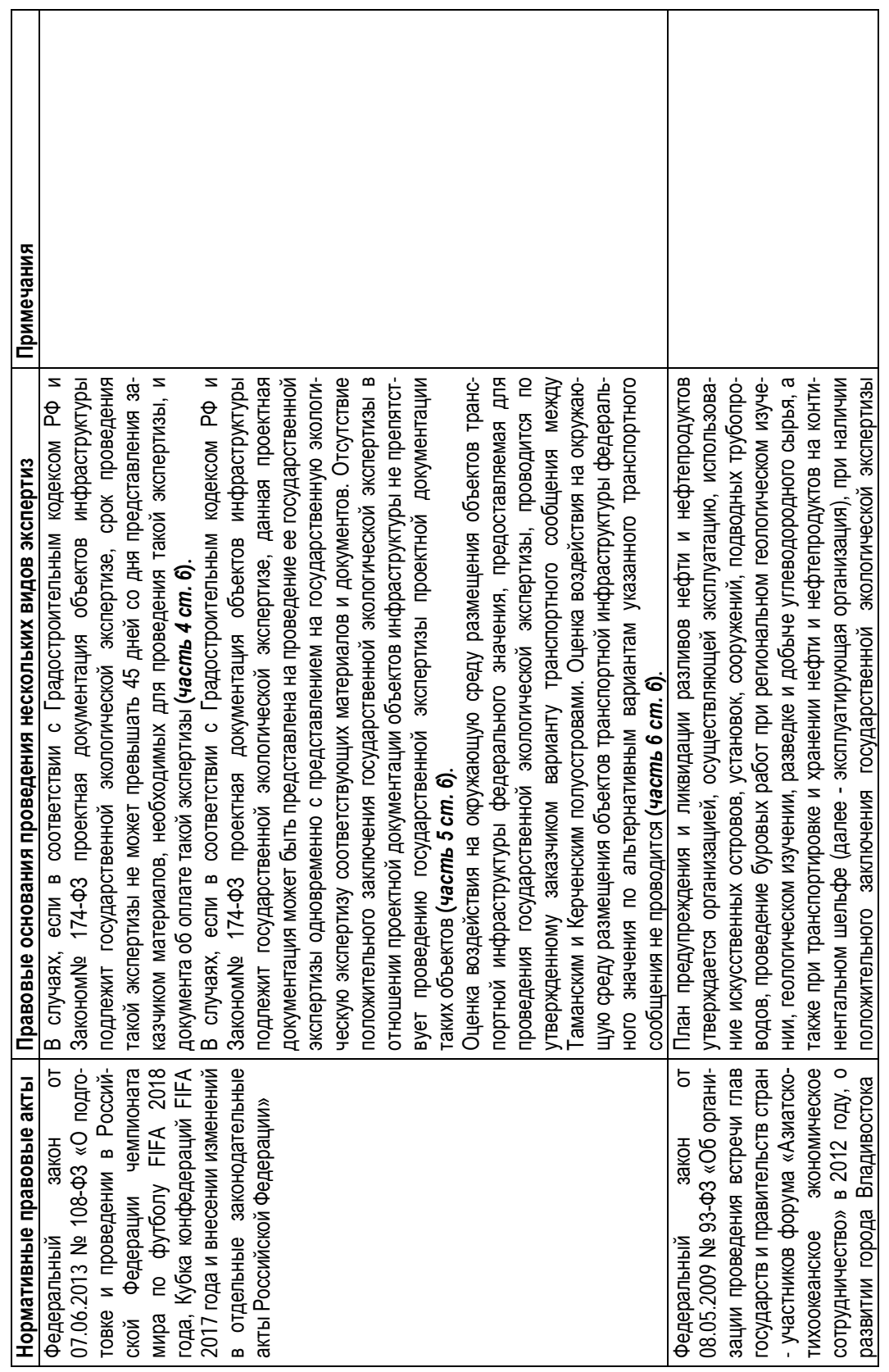




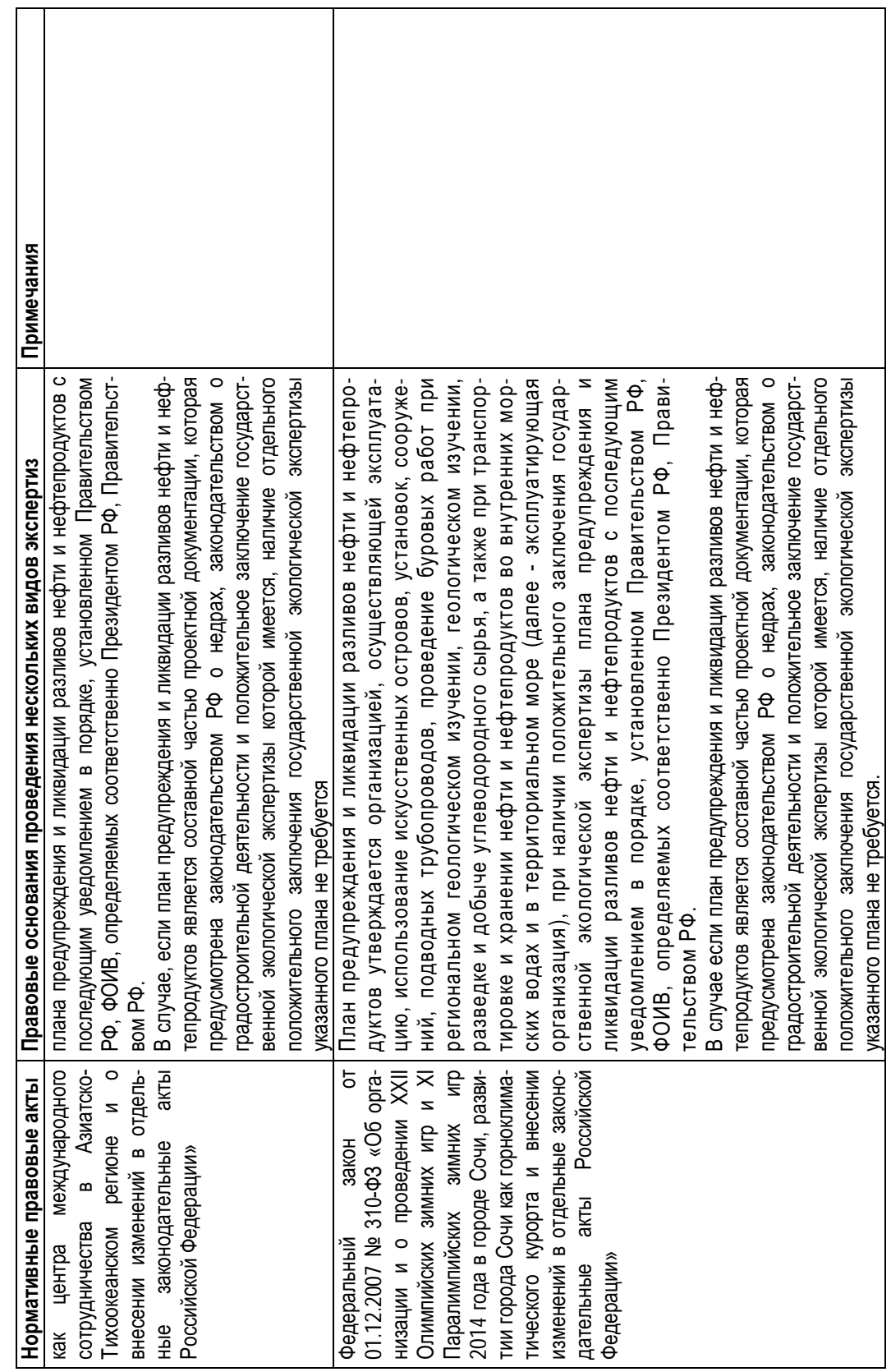




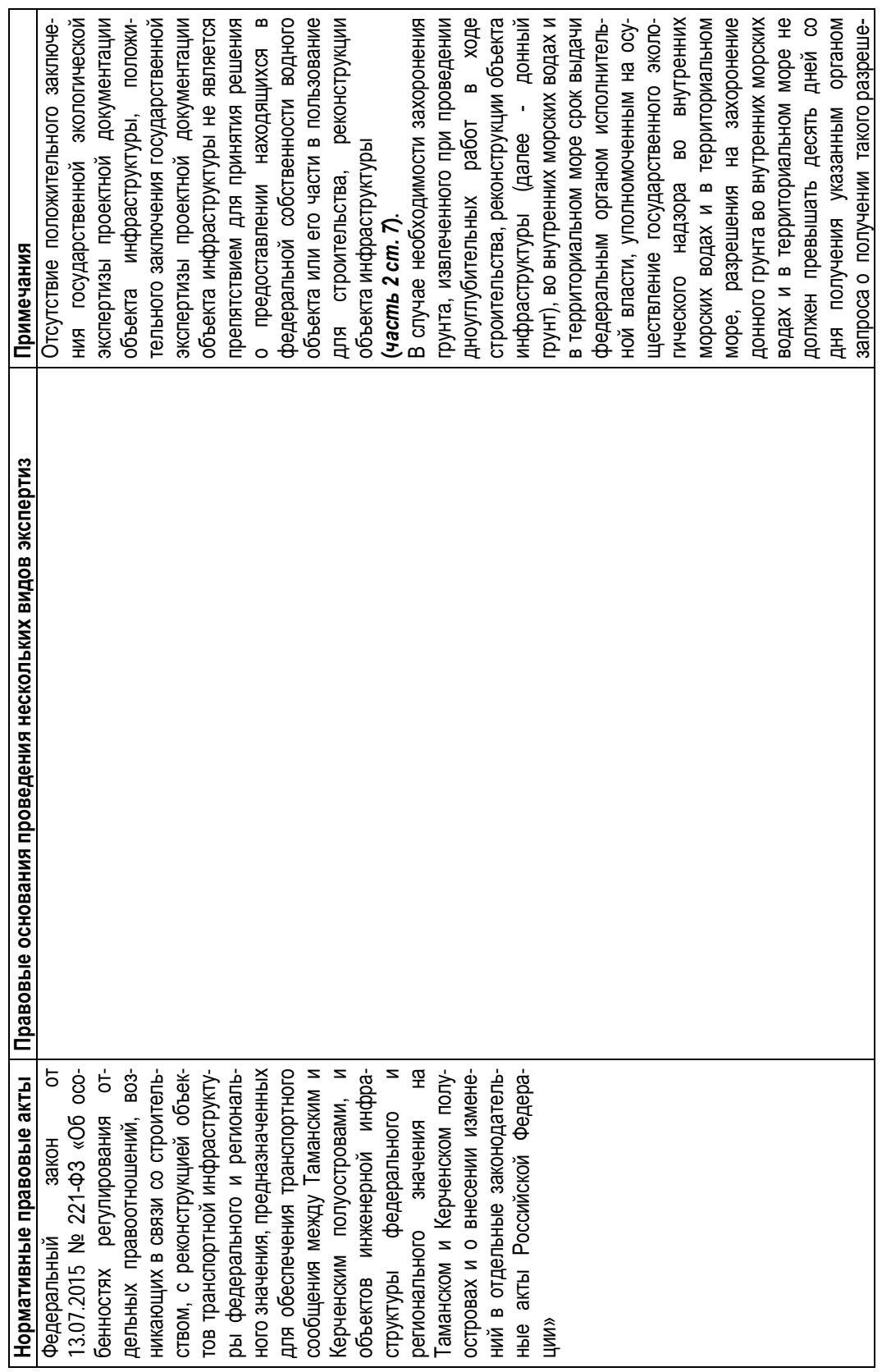




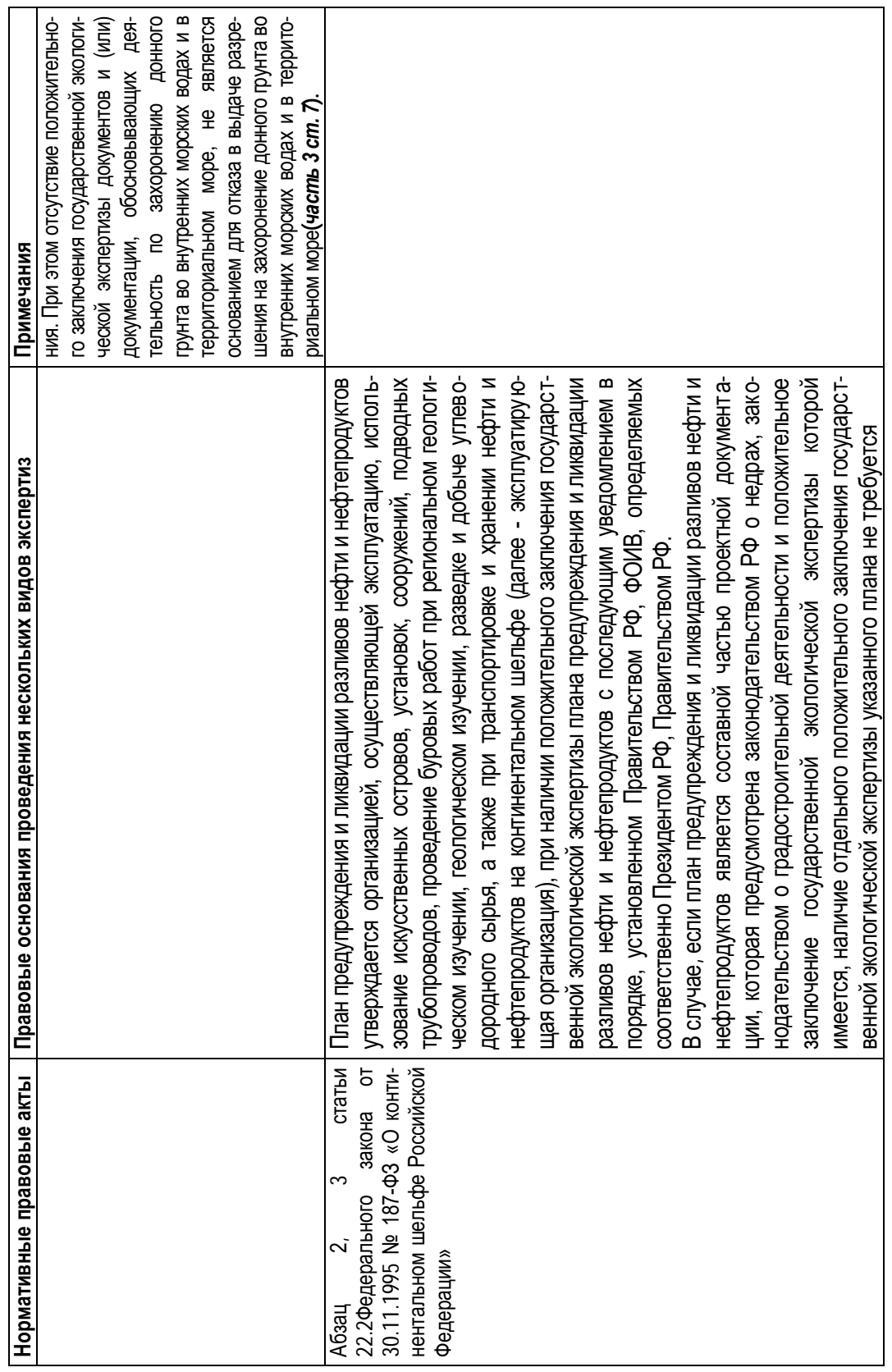




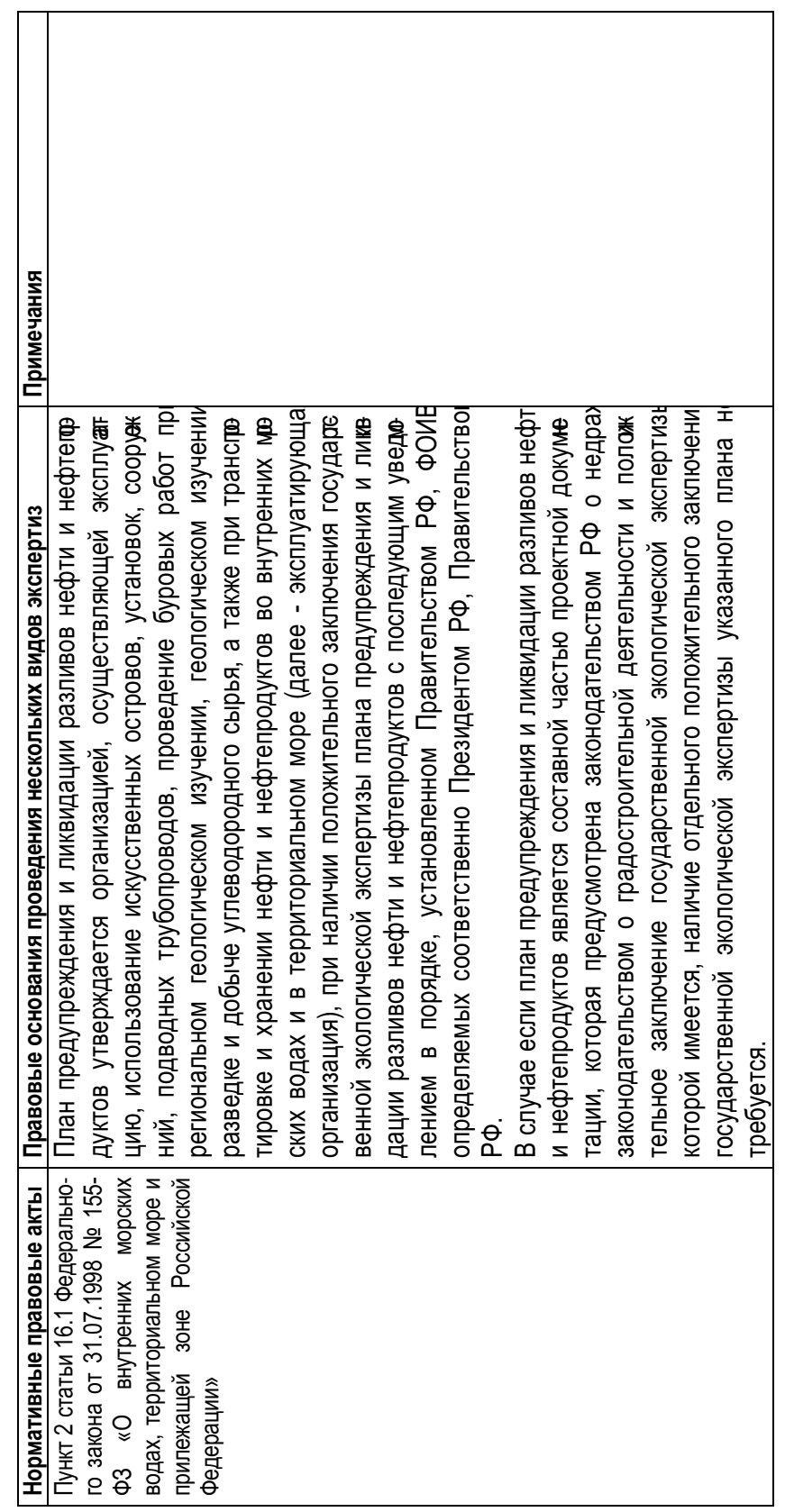


экспертизу для отнесения отдельных участков территории Российской Федерации к зонам чрезвычайной экологической ситуации или экологического бедствия»;

приказ Росприроднадзора от 30.12.2005 № 369 «Об утверждении норматива накладных расходов при определении стоимости проведения государственной экологической экспертизы в Федеральной службе по надзору в сфере природопользования»;

приказ Минприроды РФ от 28.09.1995 № 392 «Об утверждении единой формы Заключения государственной экологической экспертизы» и др.

4. В силу требований пунктов 9 - 12 статьи 14 Закона № 174-ФЗ особенности проведения государственной экологической экспертизы отдельных объектов такой экспертизы, могут устанавливаться иными федеральными законами (См.: Таблицу 1).

Письма уполномоченных органов по вопросам регулирования экологической экспертизы:

- письмо Минприроды России от 29.07.2015 № 12-47/17563 «Об изменении требований ГЭЭ объектов размещения отходов»;

- письмо Росприроднадзора от 22.09.2014 № ОД-02-00-36/14587 «О привлечении к административной ответственности»;

- письмо Росприроднадзора от 16.09.2014 № ОД-03-03-36/14249 «О направлении разъяснений»;

- письмо Росприроднадзора от 10.09.2014 № ВК-03-03-36/13927 «О направлении позиции»;

- письмо Минприроды России от 05.09.2014 № 05-12-44/20156 «О ведении государственного реестра объектов размещения отходов»;

- письмо Минприроды России от 18.08.2014 № 05-12-44/18132 «По вопросу разъяснения применения природоохранного законодательства Российской Федерации при отнесении иловых осадков к отходам производства»;

- письмо Минприроды России от 02.06.2014 № 05-12-44/11342 «Об использовании отходов производства и потребления для рекультивации карьерных выемок и искусственно созданных полостей»;

- письмо Минприроды России от 19.05.2014 № 05-12-44/10285 «0 разъяснении законодательства по вопросу размещения отходов организациями, производящими добычу полезных ископаемых»;

- письмо Росприроднадзора от 09.08.2013 № BC-08-05-32/11409 «0 рассмотрении обращения»;

- письмо Росприроднадзора от 23.05.2013 № ВК-08-05-36/7104 «О государственной экологической экспертизе»;

- письмо Госстроя от 22.03.2013 № 1976-БМ/11/ГС «О направлении проектной документации объектов на государственную экологическую экспертизу»; 
- письмо Минприроды России от 30.10.2012 № 12-50/4431-ОГ «О рассмотрении обращения»;

- письмо Минрегиона России от 02.08.2012 № 20048-ИГ/17 «О направлении проектной документации для проведения государственной экспертизы и государственной экологической экспертизы»;

- письмо Минприроды РФ от 13.05.2011 № 05-12-44/7250 «О проведении государственной экологической экспертизы проектов технической документации на новые технику, технологию» и др.

\section{2. Понятие, предмет и принципы экологической экспертизы}

Конституция гарантирует право каждого на благоприятную окружающую среду, достоверную информацию о ее состоянии и на возмещение ущерба, причиненного его здоровью или имуществу экологическим правонарушением.

При реализации данных конституционных требований в целях обеспечения экологической безопасности необходимо создать эффективный правовой механизм рационального природопользования и охраны окружающей среды от вредных воздействий. К основным элементам такого механизма относятся оценка воздействия хозяйственной деятельности человека на окружающую среду и экологическая экспертиза.

Государственная экологическая экспертиза является правовым средством обеспечения выполнения экологических требований, гарантирующих защиту и сохранение окружающей среды и способом реализации права каждого на благоприятную окружающую среду, представляет собой источник экологически значимой информации и служит средством доказывания при разрешении споров в сфере охраны окружающей среды. Экологическая экспертиза - это процедура, при проведении которой выявляется соответствие намечаемой хозяйственной и иной деятельности установленным экологическим требованиям.

Согласно Конституции, Российская Федерация - социальное государство, политика которого направлена на создание условий, обеспечивающих достойную жизнь. Соответственно, целью экологической экспертизы является не только предотвращение негативного воздействия намечаемой хозяйственной деятельности на окружающую среду, но и предупреждение связанных с нею социальных, экономических последствий реализации объекта экологической экспертизы, которые способны снижать уровень жизни людей.

В соответствии с Конституцией земля и другие природные ресурсы используются и охраняются в Российской Федерации как основа жизни и деятельности народов, проживающих на соответствующей территории. В соответствии с этим в статье 1 Земельного кодекса Российской Федерации закреплен принцип приоритета охраны земли как важнейшего компонента окру- 
жающей среды и средства производства в сельском хозяйстве и лесном хозяйстве перед использованием земли в качестве недвижимого имущества.

В соответствии с Конституцией каждый имеет право на благоприятную окружающую среду, каждый обязан сохранять природу и окружающую среду, бережно относиться к природным богатствам, которые являются основой устойчивого развития, жизни и деятельности народов, проживающих на территории Российской Федерации.

Определение экологической экспертизы дано в статье 1 Закона № 174Ф3: это установление соответствия документов и (или) документации, обосновывающих намечаемую в связи с реализацией объекта экологической экспертизы хозяйственную и иную деятельность, экологическим требованиям, установленным техническими регламентами и законодательством в области охраны окружающей среды, в целях предотвращения негативного воздействия такой деятельности на окружающую среду.

В силу требований пункта 1 статьи 33 Закона № 174-ФЗ экологическая экспертиза проводится в целях установления соответствия документов и (или) документации, обосновывающих планируемую хозяйственную и иную деятельность, требованиям в области охраны окружающей среды.

Таким образом, объектом экспертизы являются документы и (или) документация, обосновывающие планируемую хозяйственную и иную деятельность.

Объектный состав государственной экологической экспертизы конкретизирован в статье 11 Закона № 174-Ф3 (См.: Таблицу 2).

Предметом экспертизы являются требования, предъявляемые к объекту экспертизы:

- экологические требования, установленные техническими регламентами;

- экологические требования, установленные законодательством в области охраны окружающей среды.

Статья 1 Закона № 7-ФЗ раскрывает определение природоохранных требований как предъявляемые к хозяйственной и иной деятельности обязательные условия, ограничения или их совокупность, установленные законами, иными нормативными правовыми актами, нормативами в области охраны окружающей среды, федеральными нормами и правилами в области охраны окружающей среды и иными нормативными документами в области охраны окружающей среды.

Указанная правовая норма, во-первых, устанавливает обязательность природоохранных требований, во-вторых, определяет источники, в которых соответствующие требования могут содержаться, а именно:

- законы;

- иные нормативные правовые акты;

- нормативы в области охраны окружающей среды;

- иные нормативные документы в области охраны окружающей среды. 
К нормативным правовым актам помимо Конституции, федеральных конституционных законов, федеральных законов, относятся нормативные правовые акты Президента РФ, нормативные правовые акты Правительства РФ, нормативные правовые акты ФОИВ и нормативные правовые акты субъектов РФ.

Постановлением Правительства РФ от 13.08.1997 №10095 утверждены Правила подготовки нормативных правовых актов федеральных органов исполнительной власти и их государственной регистрации. В силу требований указанных Правил нормативные правовые акты издаются федеральными органами исполнительной власти в виде постановлений, приказов, распоряжений, правил, инструкций и положений, должны пройти процедуру регистрации в Минюсте РФ и должны быть официально опубликованы.

Статья 1 Закона № 7-ФЗ раскрывает понятие «нормативы в области охраны окружающей среды» - это установленные нормативы качества окружающей среды и нормативы допустимого воздействия на нее, при соблюдении которых обеспечивается устойчивое функционирование естественных экологических систем и сохраняется биологическое разнообразие.

Цель проведения экологической экспертизы - предотвращение негативного воздействия намечаемой (планируемой) хозяйственной деятельности на окружающую среду.

Статья 3 Закона № 7-ФЗ устанавливает следующие принципы, на которых должны основываться экологическая экспертиза:

- презумпция потенциальной экологической опасности любой намечаемой хозяйственной и иной деятельности;

- обязательность проведения государственной экологической экспертизы до принятия решений о реализации объекта экологической экспертизы;

- комплексность оценки воздействия на окружающую среду хозяйственной и иной деятельности и его последствий;

- обязательность учета требований экологической безопасности при проведении экологической экспертизы;

- достоверность и полнота информации, представляемой на экологическую экспертизу;

- независимость экспертов экологической экспертизы при осуществлении ими своих полномочий в области экологической экспертизы;

- научная обоснованность, объективность и законность заключений экологической экспертизы;

- гласность, участие общественных организаций (объединений), учет общественного мнения;

- ответственность участников экологической экспертизы и заинтересованных лиц за организацию, проведение, качество экологической экспертизы.

${ }^{5}$ Постановление Правительства РФ от 13.08.1997 № 1009 «Об утверждении Правил подготовки нормативных правовых актов федеральных органов исполнительной власти и их государственной регистрации». 
Признаком экологической экспертизы, отличающей ее от иных форм экспертиз, является возможность участия общественных организаций при ее проведении и учет общественного мнения.

В состав экспертной комиссии государственной экологической экспертизы в обязательном порядке включаются внештатные эксперты - ученые и специалисты различных областей науки, каждый из которых является специалистом в узкой сфере. По согласованию с ними и в случаях, определенных нормативными правовыми актами федерального органа исполнительной власти в области экологической экспертизы, в состав экспертной комиссии государственной экологической экспертизы могут включаться в качестве экспертов штатные сотрудники данного органа и иные сотрудники органов государственной власти субъектов Российской Федерации (статья 15 Закона № 7-ФЗ).

Эксперты экологической экспертизы осуществляют свои полномочия в области экологической экспертизы на основе принципа независимости, в условиях гласности, при участии общественных организаций (объединений) и с учетом общественного мнения. Обязательное участие представителей общественности при проведении экологической экспертизы является частным случаем непосредственного участия граждан в управлении делами государства.

Одним из объектов экологической экспертизы выступает проектная документация. В силу требований Градостроительного кодекса РФ по общему правилу не допускается проведение иных экспертиз проектной документации, за исключением тех, которые предусмотрены частью 6 статьи 49 Градостроительного кодекса РФ, а именно:

- экспертизы проектной документации;

- государственной историко-культурной экспертизы проектной документации на проведение работ по сохранению объектов культурного наследия;

- государственной экологической экспертизы проектной документации объектов, строительство, реконструкцию которых предполагается осуществлять в исключительной экономической зоне Российской Федерации;

- государственной экологической экспертизы проектной документации объектов, строительство, реконструкцию которых предполагается осуществлять на континентальном шельфе Российской Федерации;

- государственной экологической экспертизы проектной документации объектов, строительство, реконструкцию которых предполагается осуществлять во внутренних морских водах;

- государственной экологической экспертизы проектной документации объектов, строительство, реконструкцию которых предполагается осуществлять в территориальном море Российской Федерации;

- государственной экологической экспертизы проектной документации объектов, строительство, реконструкцию которых предполагается осуществлять на землях особо охраняемых природных территорий; 
- государственной экологической экспертизы проектной документации объектов, строительство, реконструкцию которых предполагается осуществлять на Байкальской природной территории;

- государственной экологической экспертизы проектной документации объектов, используемых для размещения и (или) обезвреживания отходов I $\mathrm{V}$ классов опасности, искусственных земельных участков на водных объектах.

В письме Госстроя от 22.03.2013 № 1976-БМ/11/ГС «О направлении проектной документации объектов на государственную экологическую экспертизу» разъясняется, что документация, получившая положительное заключение государственной экологической экспертизы, не требует дополнительной проверки на предмет соответствия экологическим требованиям при проведении ФАУ «Главгосэкспертиза» государственной экспертизы таких документов и (или) документации.

Запрет, установленный частью 6 статьи 49 Градостроительного кодекса РФ, действует только в отношении экспертизы проектной документации. При этом в силу требований части 2 статьи 48 Градостроительного кодекса РФ проектная документация представляет собой документацию, определяющую архитектурные, функционально-технологические, конструктивные и инженерно-технические решения, необходимые для обеспечения строительства, реконструкции объектов капитального строительства, а также их капитального ремонта. Таким образом, проектная документация готовится в отношении строящихся и реконструируемых объектов капитального строительства. Получается, в отношении иной документации (например, документации на консервацию или ликвидацию) указанный запрет не распространяется. Отметим отдельно, что в силу требований статей 8, 13 Федерального закона от 21.07.1997 № 116-Ф3 «О промышленной безопасности опасных производственных объектов» документация на консервацию и документация на ликвидацию опасного производственного объекта подлежит экспертизе промышленной (но не экологической) безопасности.

\section{3. Виды экологической экспертизы}

В соответствии со статьей 4 Закона № 174-ФЗ в Российской Федерации осуществляются два вида экологической экспертизы:

1) государственная экологическая экспертиза - организуется и проводится федеральным органом исполнительной власти в области экологической экспертизы или органами государственной власти субъектов Российской Федерации в порядке, установленном Федеральным законом, иными нормативными правовыми актами Российской Федерации, законами и иными нормативными правовыми актами субъектов Российской Федерации; 
2) общественная экологическая экспертиза - организуется и проводится по инициативе граждан и общественных организаций (объединений), а также по инициативе органов местного самоуправления общественными организациями (объединениями), основным направлением деятельности которых в соответствии с их уставами является охрана окружающей среды, в том числе организация и проведение экологической экспертизы, и которые зарегистрированы в порядке, установленном законодательством Российской Федерации.

\section{4. Объекты экологической экспертизы}

Перечень объектов государственной экологической экспертизы приведен в статьях 11 и 12 Закона № 174-ФЗ.

Объектами общественной экологической экспертизы в силу требований статьи 21 Закона № 174-ФЗ являются объекты, указанные в статьях 11 и 12 данного Федерального закона, за исключением объектов экологической экспертизы, сведения о которых составляют государственную, коммерческую и (или) иную охраняемую законом тайну.

В соответствии с требованиями статей 11 и 12 Закона № 174-ФЗ объектами государственной экологической экспертизы является соответствующая документация - проекты, материалы, проектная документация, обосновывающие планируемую хозяйственную деятельность. Сама хозяйственная деятельность объектом государственной экологической экспертизы являться не может.

Перечень объектов государственной экологической экспертизы, установленный в статьях 11 и 12 Закона № 174-ФЗ не является исчерпывающим.

Во-первых, в тексте статьи 11 Закона № 174-ФЗ содержатся ссылки на иные федеральные законы, определяющие объекты такой экспертизы.

Например, в силу требований пункта 7 статьи 11 Закона № 174-Ф3 объекты государственной экологической экспертизы определяются в Федеральном законе от 30.11.1995 № 187-Ф3 «О континентальном шельфе Российской Федерации» (далее - Закон № 187-Ф3), Федеральном законе от 17.12.1998 № 191-Ф3 «Об исключительной экономической зоне Российской Федерации» (далее - Закон № 191-ФЗ), Федеральном законе от 31.07.1998 № 155-ФЗ «О внутренних морских водах, территориальном море и прилежащей зоне Российской Федерации» (далее - Закон № 155-ФЗ).

Во-вторых, помимо требований статей 11 и 12 Закона № 174-Ф3, существует целый ряд иных нормативных правовых актов (федеральных законов, постановлений Правительства РФ), определяющих объекты, подлежащие государственной экологической экспертизе и не нашедшие отражение в упомянутых статьях Закона № 174-ФЗ. В связи с чем возникают 
проблемы в определении их статуса и правовом обосновании необходимости проведения в отношении таких объектов государственной экологической экспертизы.

Согласно статье 20 Федерального закона от 24.04.1995 № 52-Ф3 «О животном мире» (далее - Закон № 52-Ф3) обязательной государственной экологической экспертизе подлежат удобрения, пестициды и биостимуляторы роста растений, а также материалы, обосновывающие объемы (лимиты, квоты) изъятия объектов животного мира и проведения работ по акклиматизации и гибридизации этих объектов.

Согласно абзацу 1 статьи 20 Закона № 52-ФЗ обязательной мерой охраны животного мира является государственная экологическая экспертиза, осуществляемая в соответствии с законодательством Российской Федерации и предшествующая принятию органами исполнительной власти Российской Федерации и органами исполнительной власти субъектов Российской Федерации хозяйственного решения, способного повлиять на объекты животного мира и среду их обитания. При этом в силу требований абзаца 2 статьи 20 Закона № 52-ФЗ обязательной государственной экологической экспертизе подлежат материалы, обосновывающие объем (лимиты, квоты) изъятия объектов животного мира.

В соответствии с пунктом 3 статьи 24 Федерального закона от 24.07.2009 № 209-Ф3 "Об охоте и о сохранении охотничьих ресурсов и о внесении изменений в отдельные законодательные акты Российской Федерации"(далее - Закон № 209-ФЗ) лимит добычи охотничьих ресурсов утверждается для каждого субъекта Российской Федерации высшим должностным лицом субъекта Российской Федерации (руководителем высшего исполнительного органа государственной власти субъекта Российской Федерации).

Порядок подготовки, принятия документа об утверждении лимита добычи охотничьих ресурсов, внесения в него изменений и требований к его содержанию и составу утвержден приказом Минприроды России от 27.11.2020 № 981.

Полномочие по установлению лимитов добычи охотничьих ресурсов и квот их добычи, за исключением таких лимитов и квот в отношении охотничьих ресурсов, находящихся на особо охраняемых природных территориях федерального значения, Российская Федерация передала органам государственной власти субъектов РФ.

Статьи 11 и 12 Закона № 174-ФЗ не определяют материалы, обосновывающие объемы (лимиты, квоты) изъятия объектов животного мира, в качестве самостоятельных объектов государственной экологической экспертизы, в то же время, учитывая, что в силу требований пункта 3 статьи 24 Закона № 209-ФЗ лимит добычи охотничьих ресурсов утверждается для каждого субъекта РФ высшим должностным лицом субъекта РФ, можно сделать вывод о том, что данный документ подпадает под пункт 1 статьи 12 Закона 
№ 174-Ф3 и относится к нормативному акту, подлежащему экологической экспертизе. То есть, к объектам государственной экологической экспертизы относятся нормативные правовые акты, которые в качестве самостоятельного объекта в статьях 11 и 12 Закона № 174-ФЗ не определены, однако, в статье 18 Закона № 174-ФЗ определяются особые требования к содержанию заключения государственной экологической экспертизы на проекты нормативных правовых актов. В соответствии с абзацем 1 пункта 5 статьи 18 Закона № 174-ФЗ заключение государственной экологической экспертизы по объектам, указанным в статьях 11 и 12 Закона № 174-Ф3, за исключением проектов нормативных правовых актов Российской Федерации, может быть положительным или отрицательным.

Нормативные правовые акты Российской Федерации в том смысле, в котором они упоминаются в пункте 5 статьи 18 Закона № 174-ФЗ имеют собирательное значение и по своему смыслу включают как нормативные правовые акты федерального уровня, так и нормативные правовые акты субъектов РФ.

Согласно абзаца 11 пункта 5 статьи 18 Закона № 174-ФЗ заключения государственной экологической экспертизы по проектам нормативных правовых актов Российской Федерации рассматриваются принимающими эти акты органами государственной власти.

Некоторые объекты государственной экологической экспертизы в полной мере не раскрыты ни в Законе № 174-Ф3, ни в иных нормативных правовых актах, что позволяет по-разному толковать их значение и содержание. Речь идет об объектах, обозначенных в пункте 7.2 статьи 11 Закона № 174-Ф3:

- проектная документация объектов, используемых для размещения и (или) обезвреживания отходов I - V классов опасности, в том числе проектная документация на строительство, реконструкцию объектов, используемых для обезвреживания и (или) размещения отходов I - V классов опасности, а также

- проекты вывода из эксплуатации указанных объектов, проекты рекультивации земель, нарушенных при размещении отходов I - V классов опасности, и земель, используемых, но не предназначенных для размещения отходов I - V классов опасности.

В этой связи автор полагает, что в состав объектов могут быть включены:

- учредительные документы юридического лица;

- документы Госстатистики о намерении осуществлять конкретные виды деятельности;

- техническая документация на закупаемое к установке (монтажу) оборудование;

- технологическая документация об осуществлении производственной деятельности и др. 


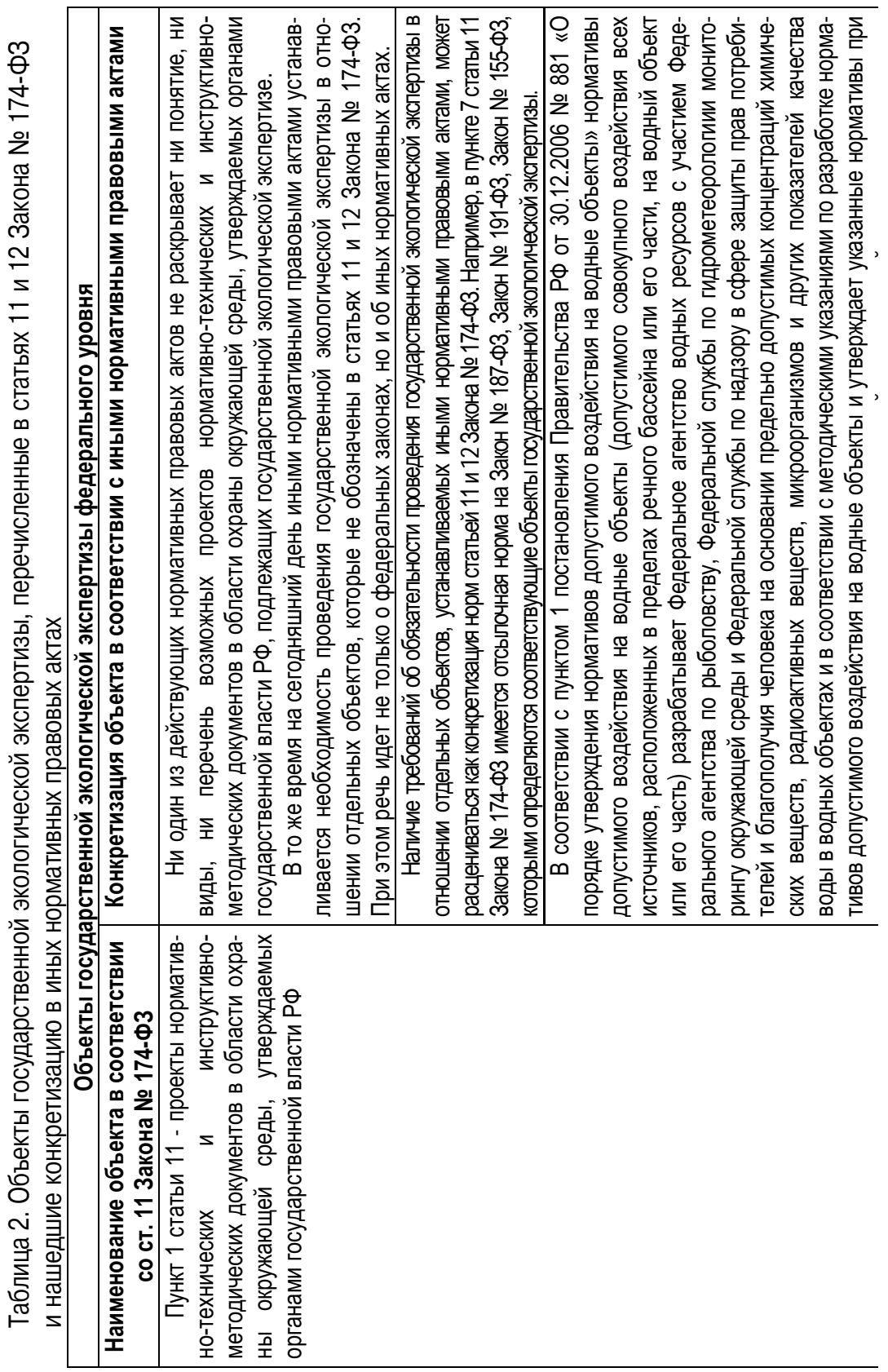




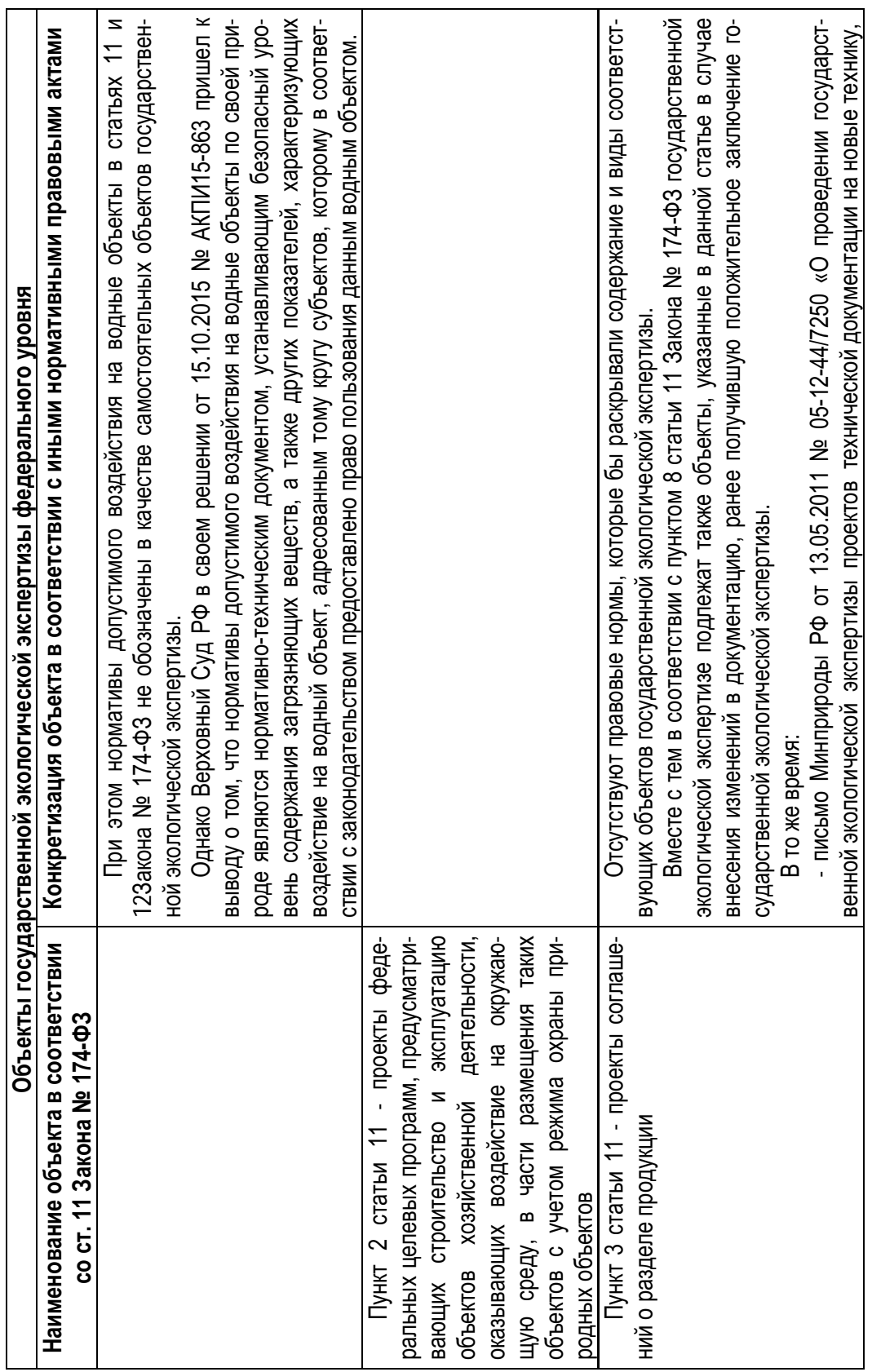




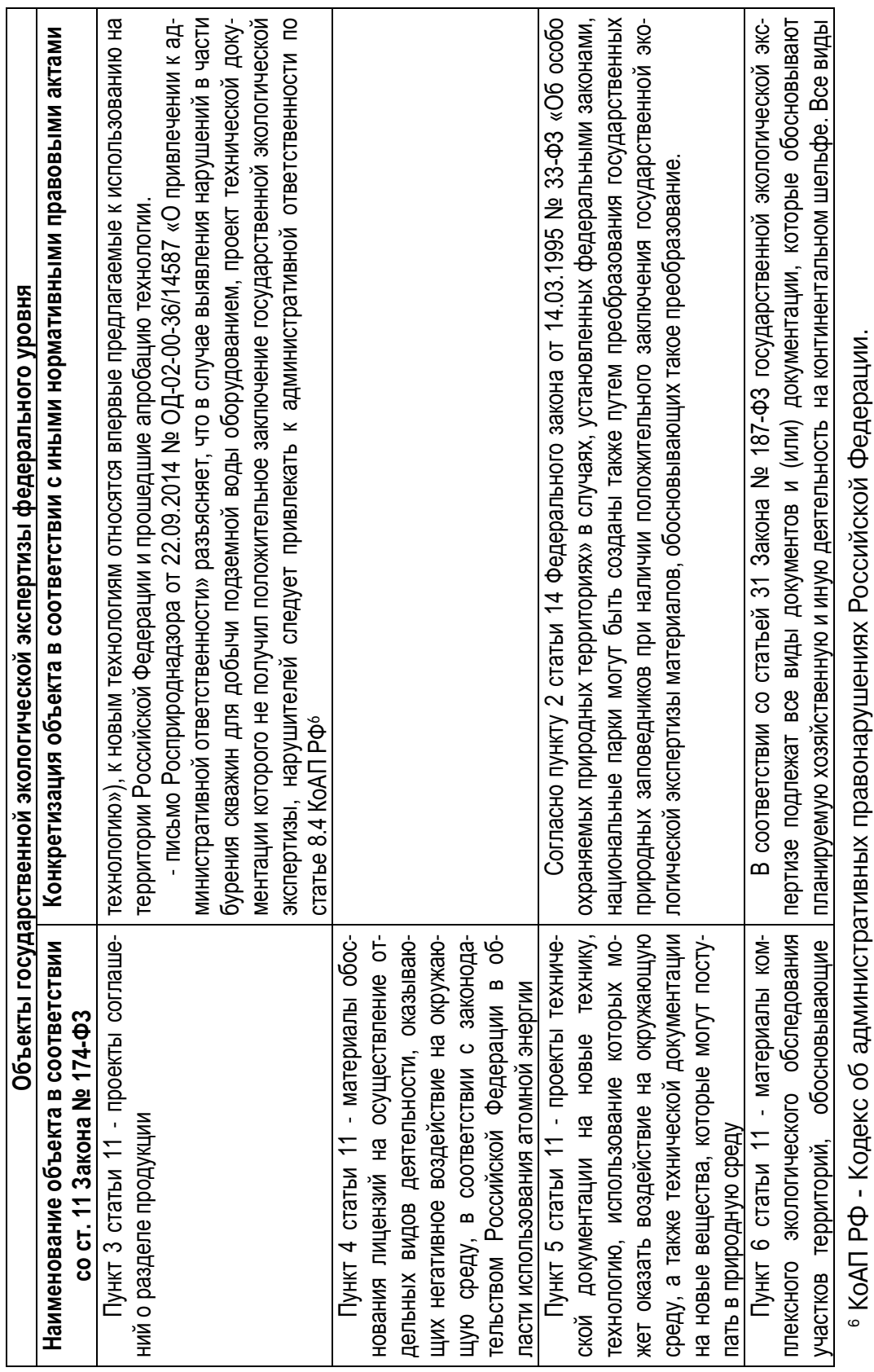




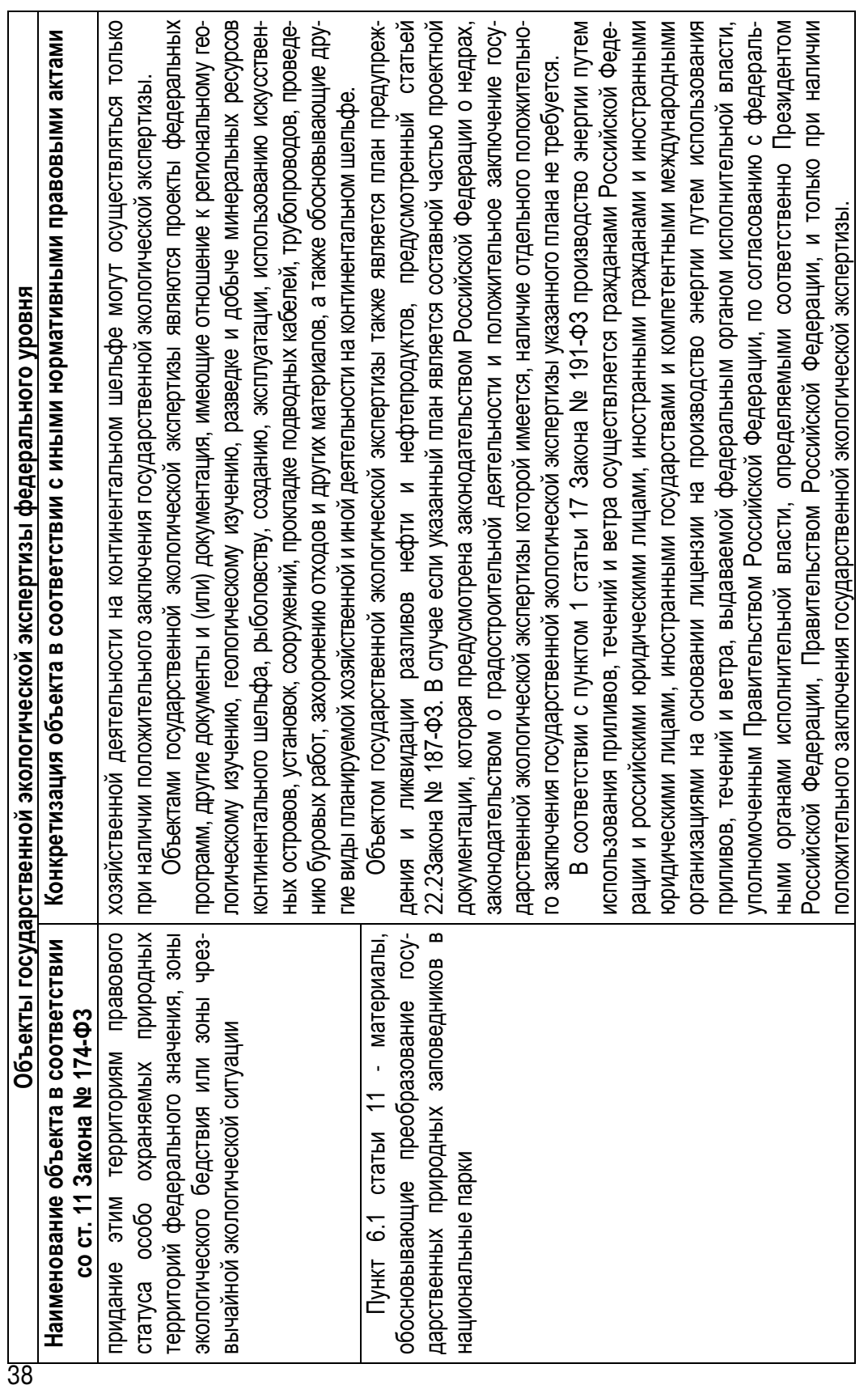




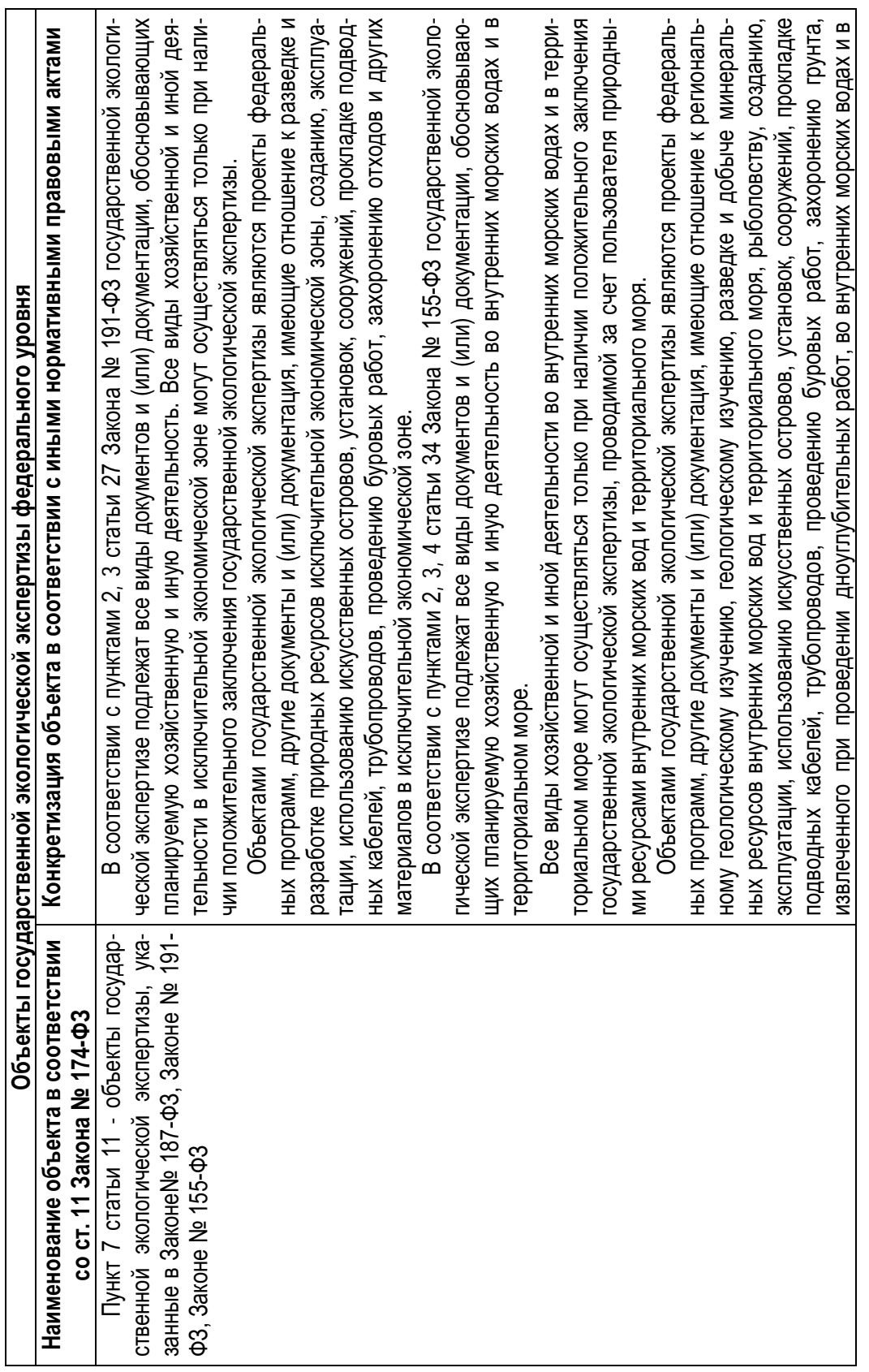




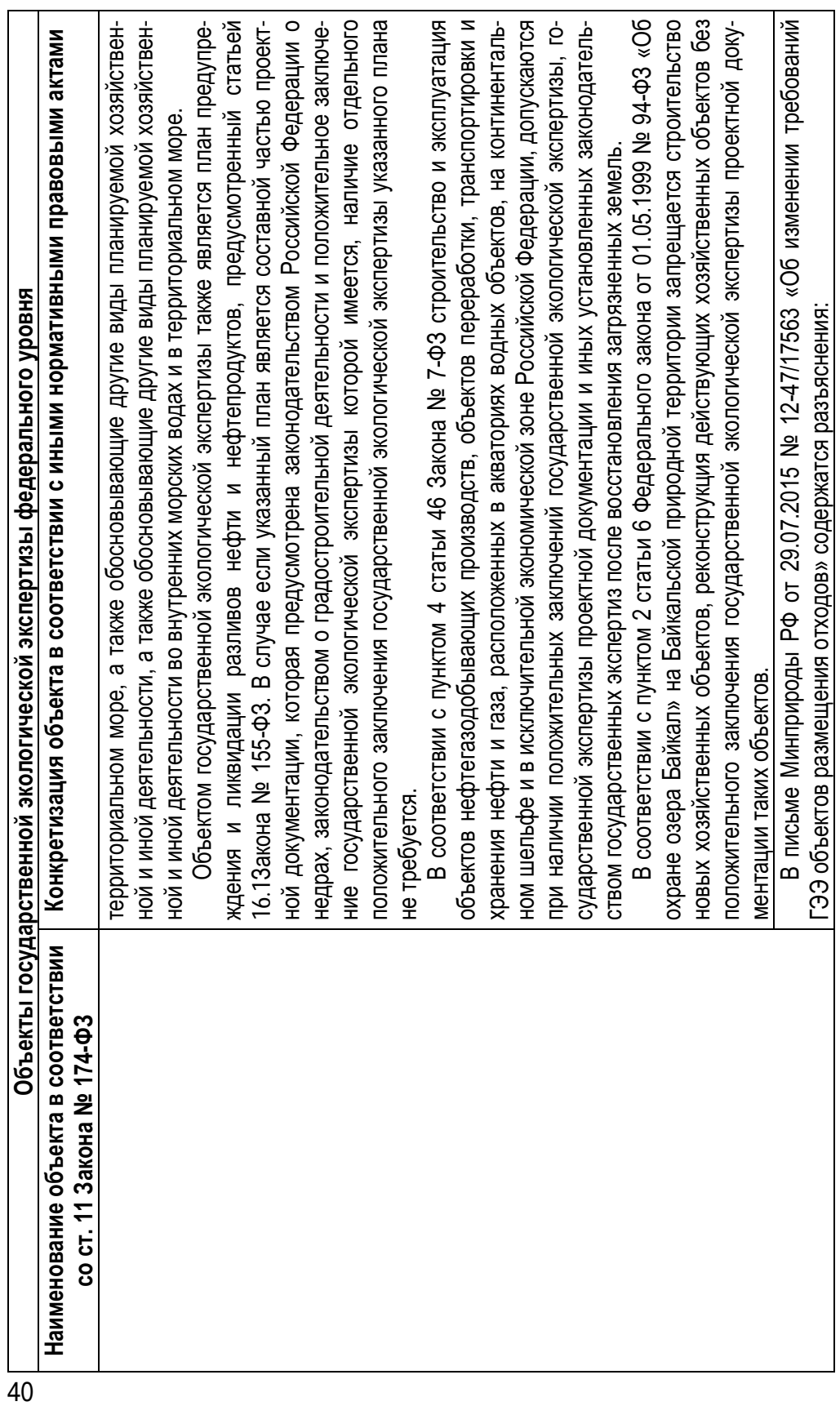




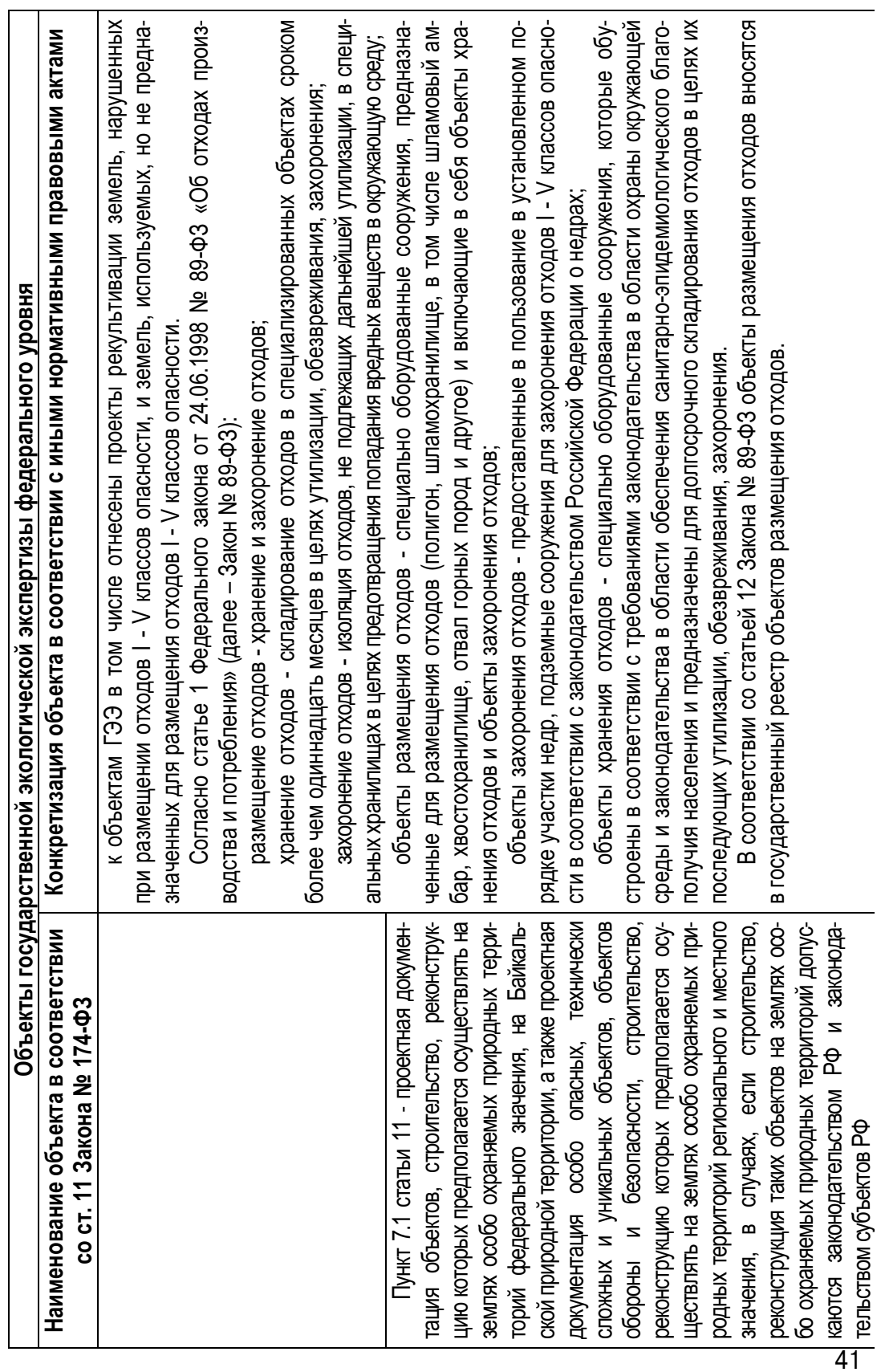




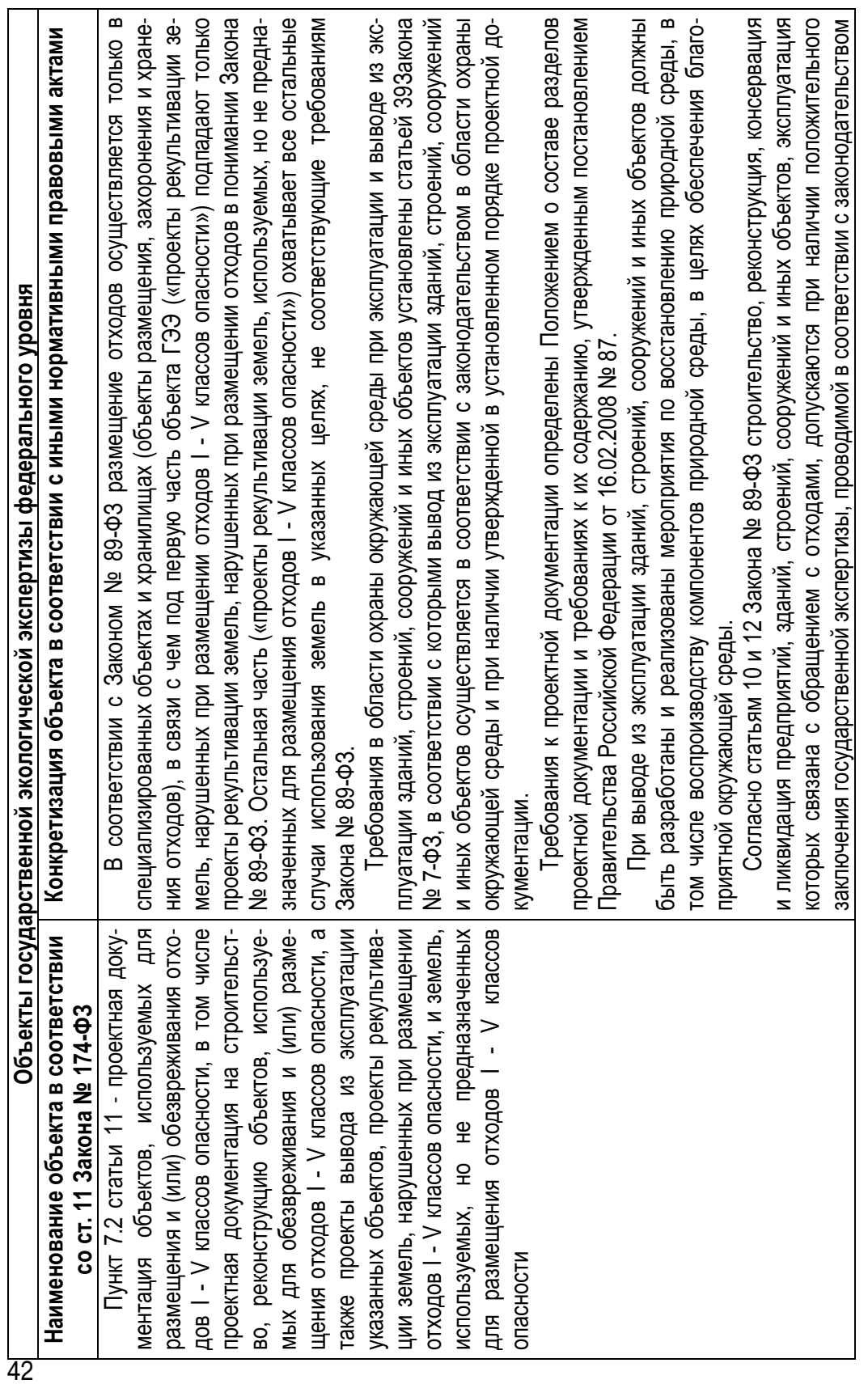




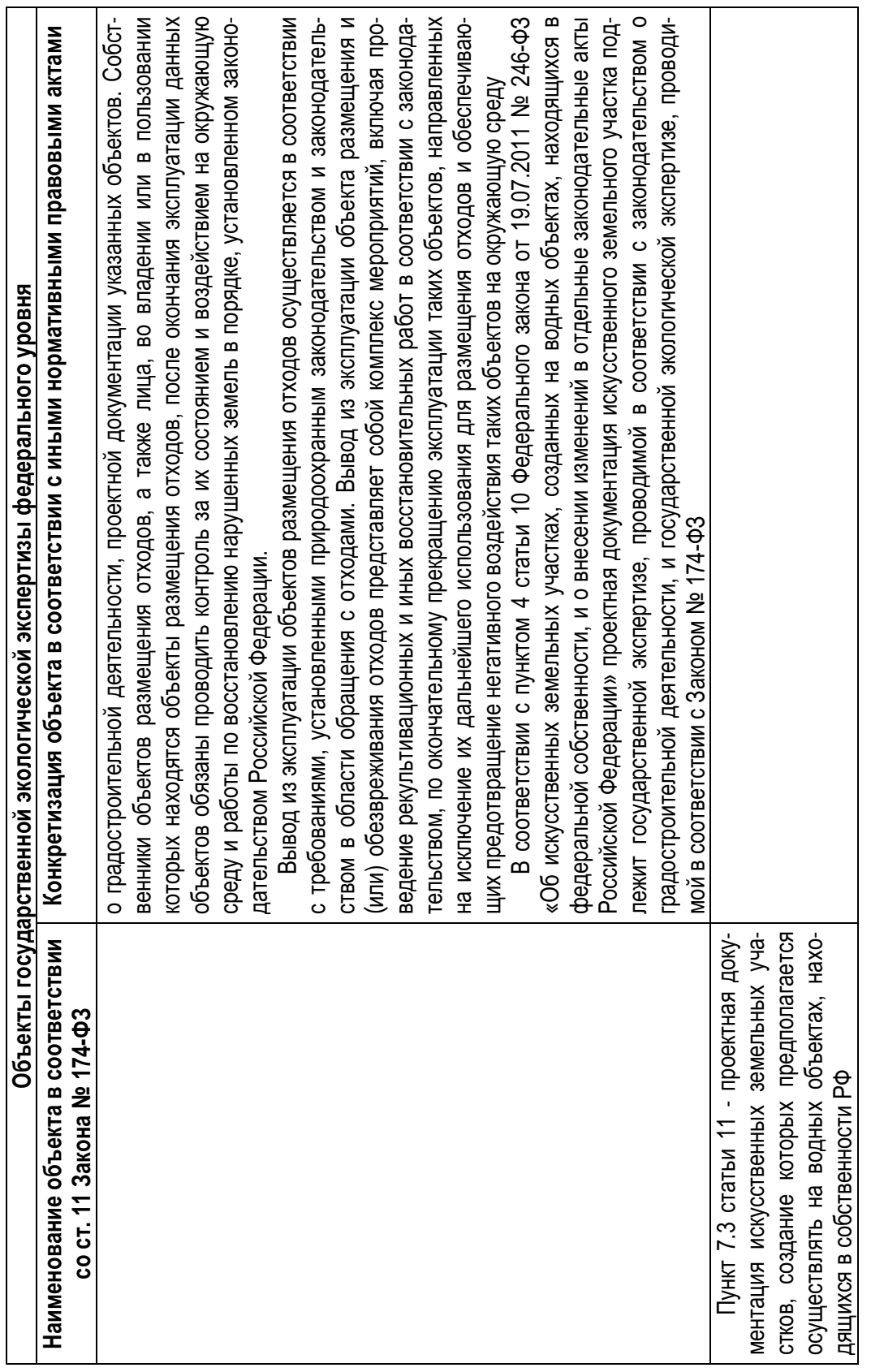




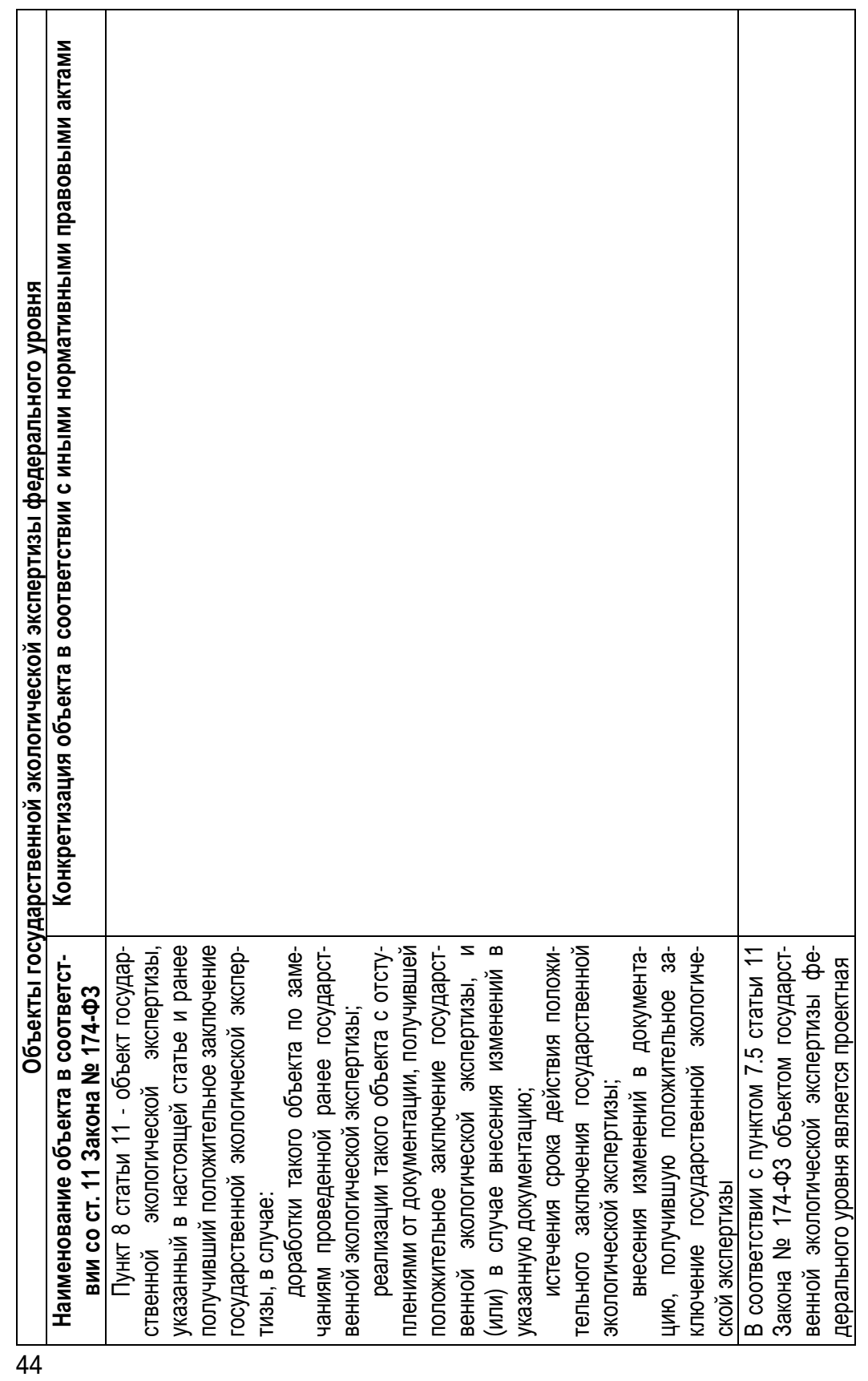




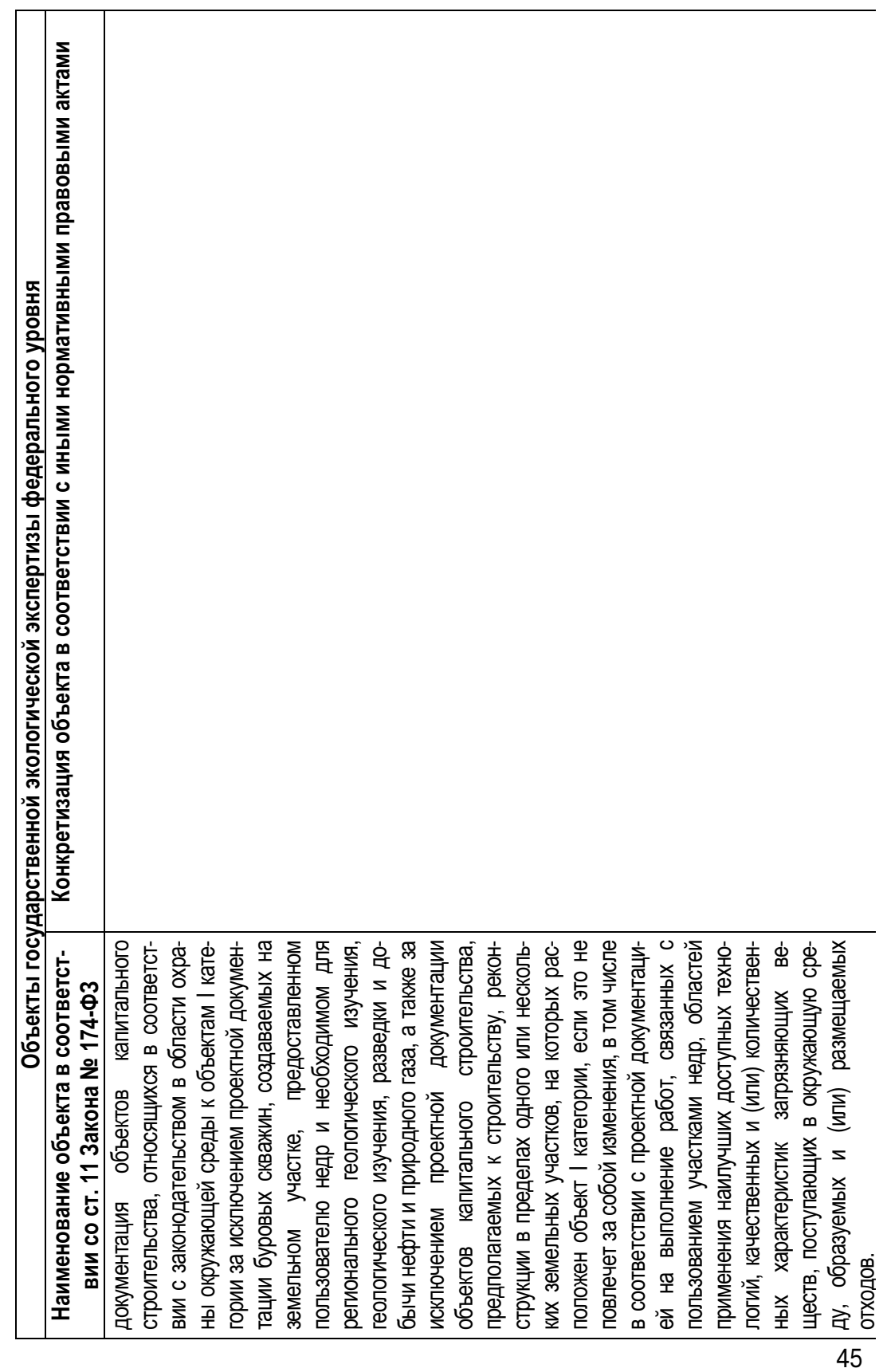




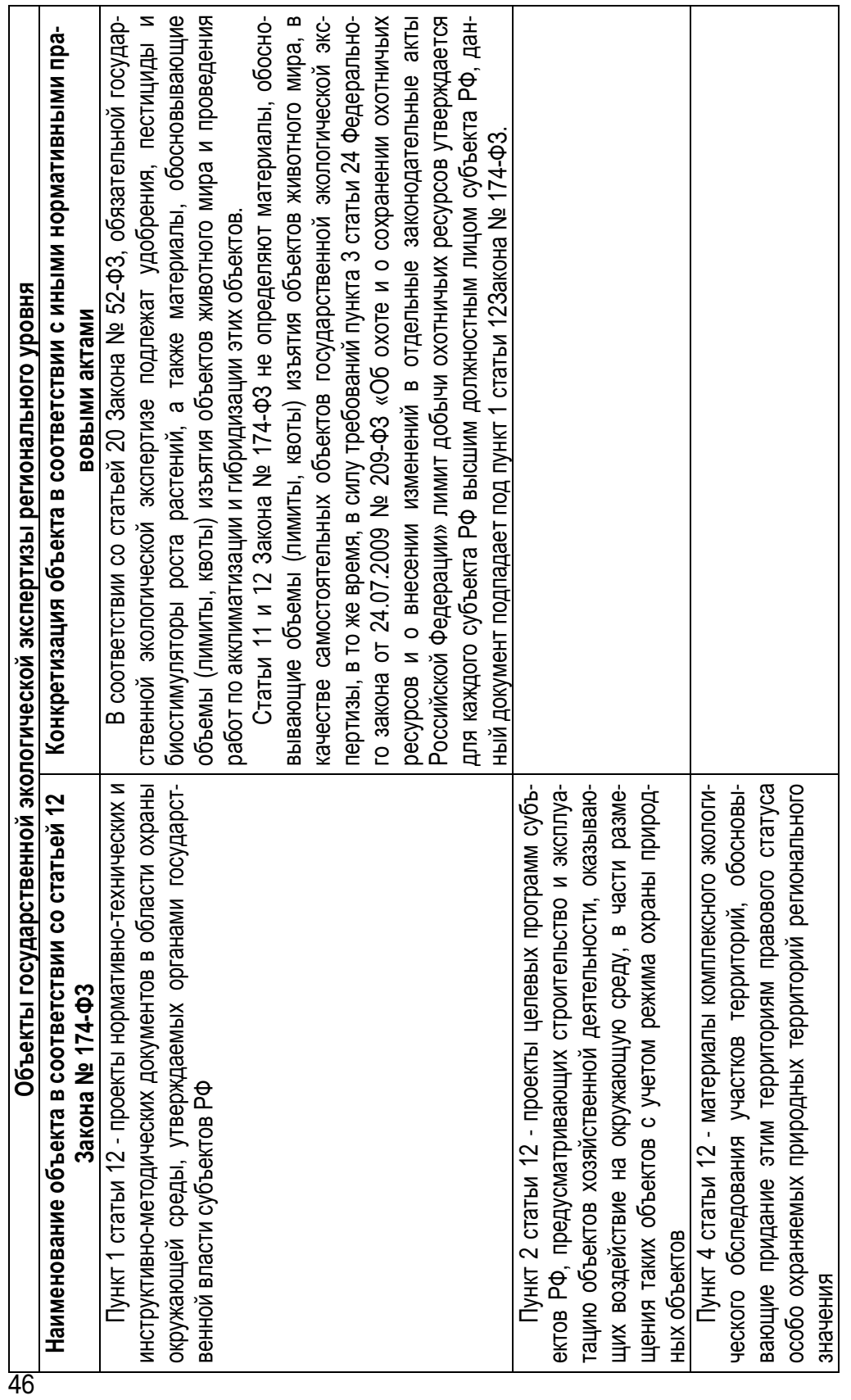




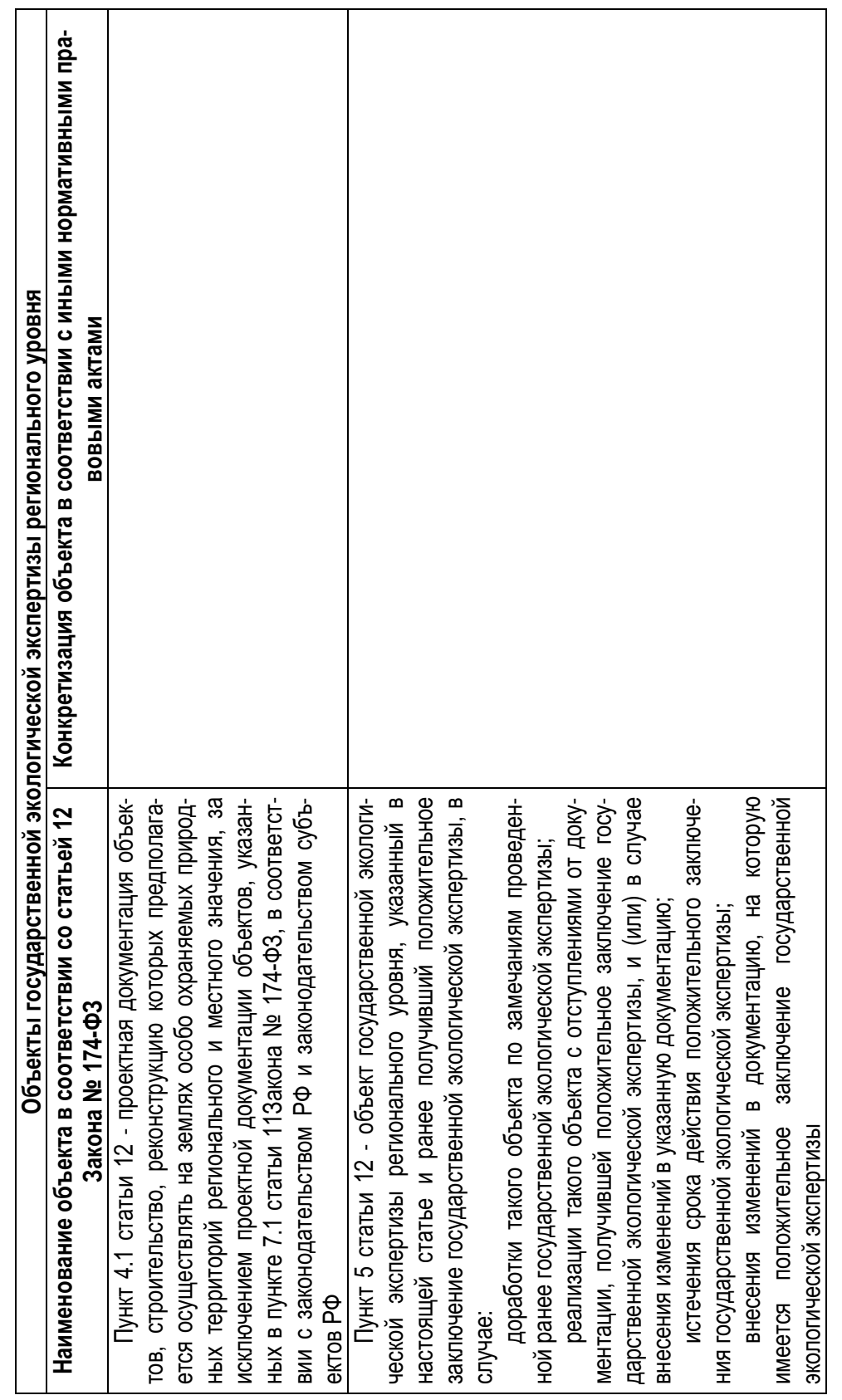




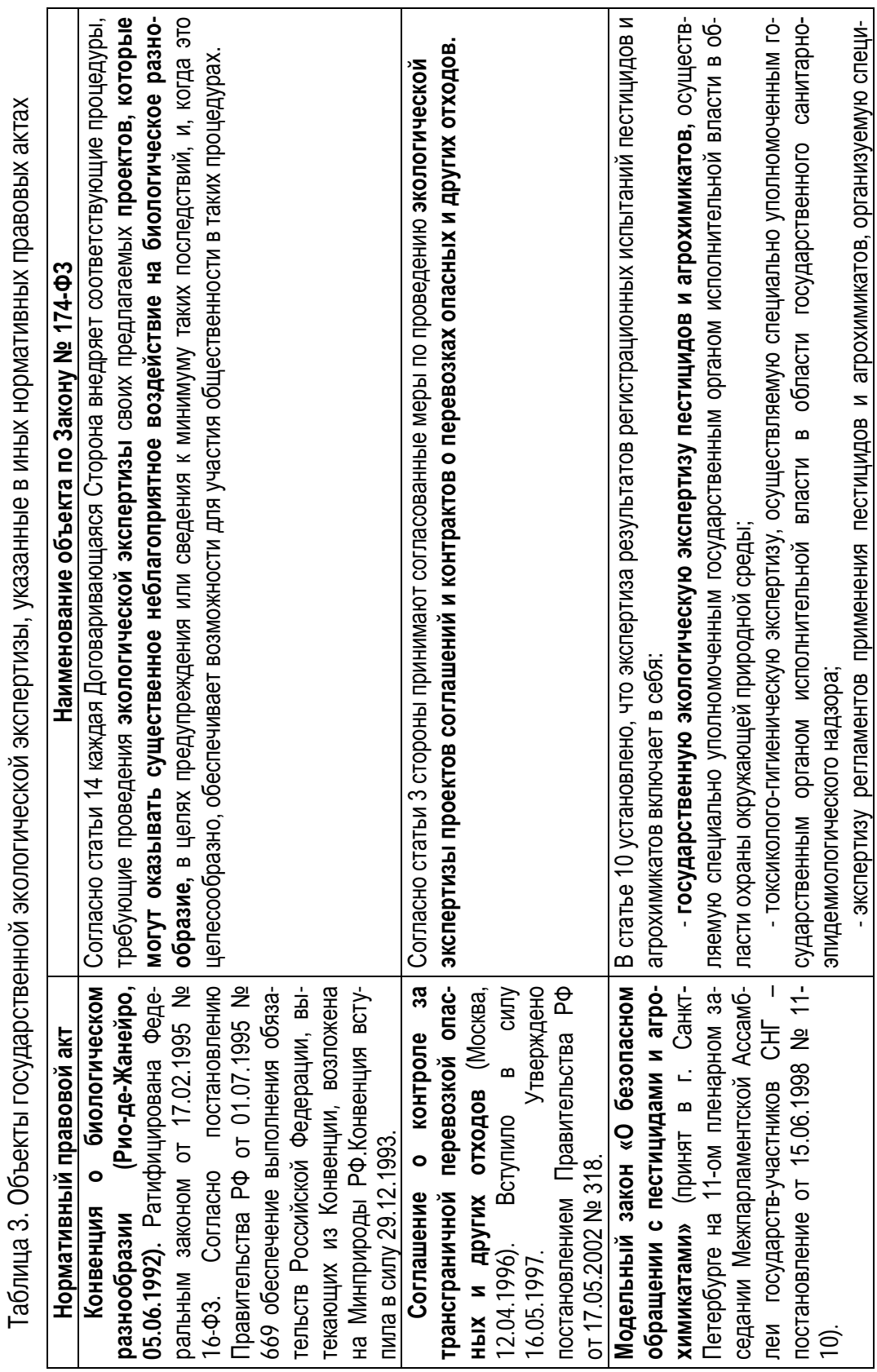




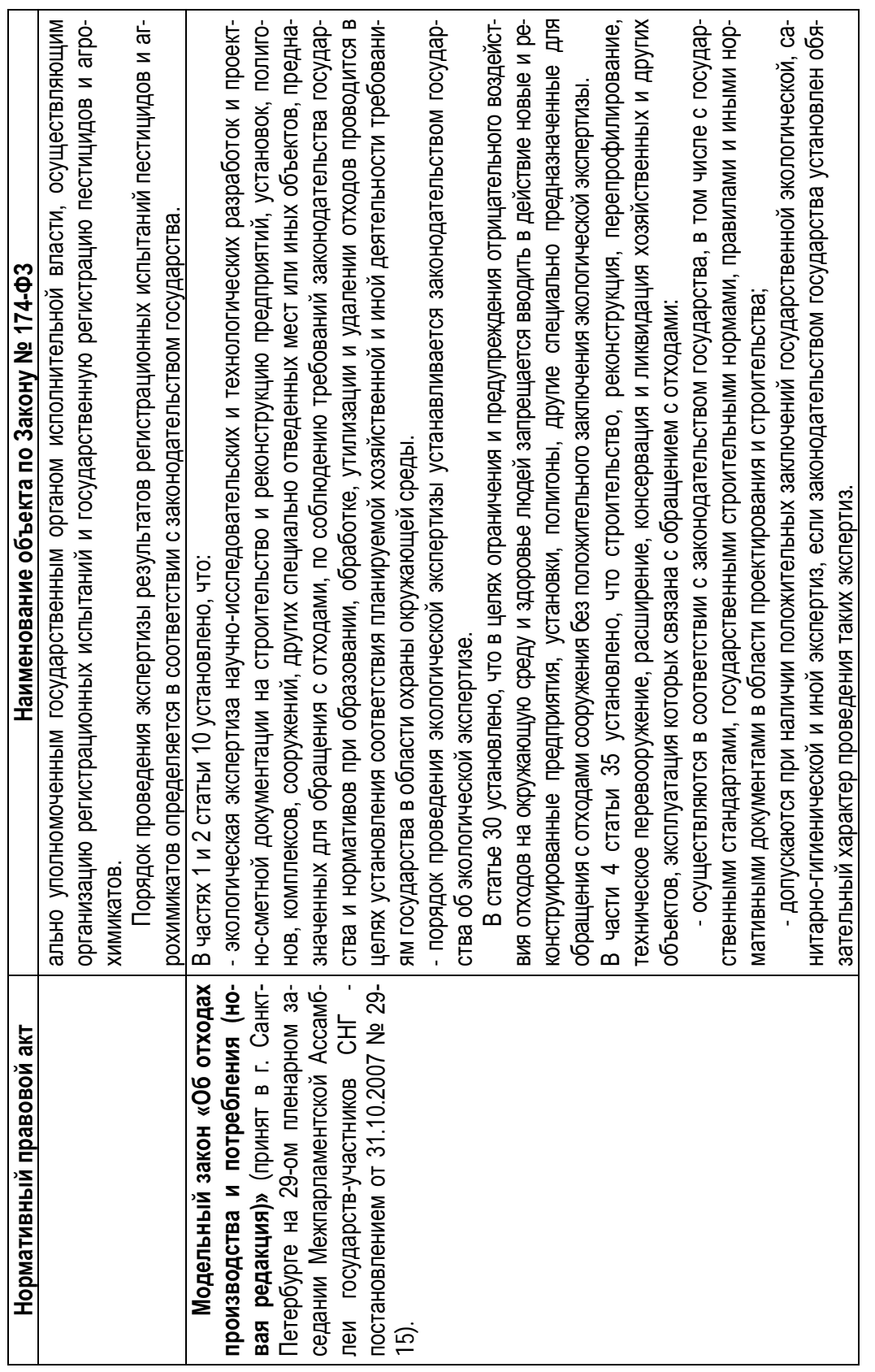




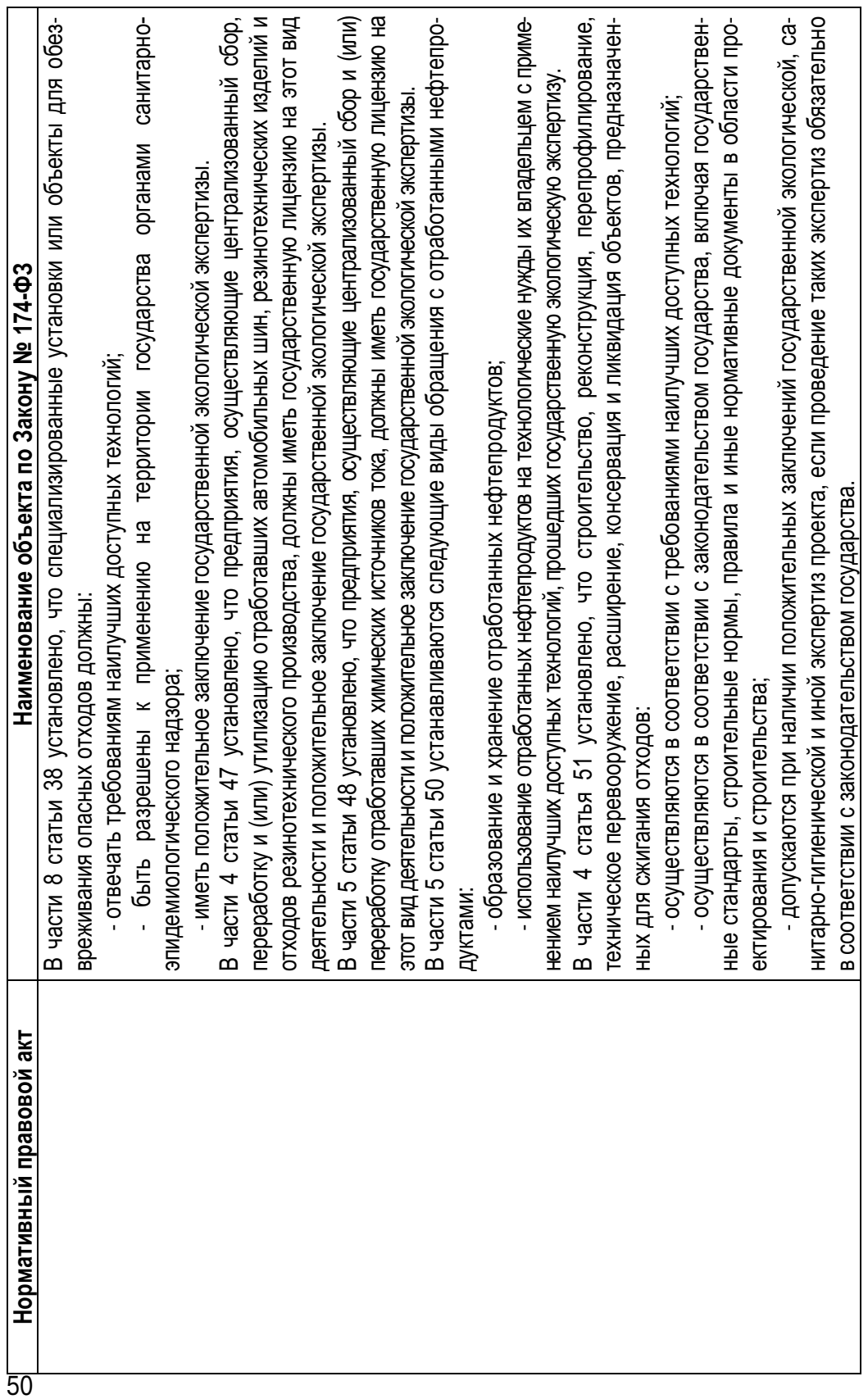




\begin{tabular}{|c|c|c|c|c|}
\hline 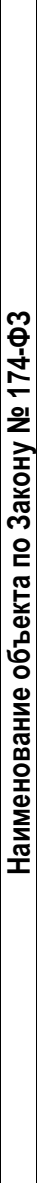 & 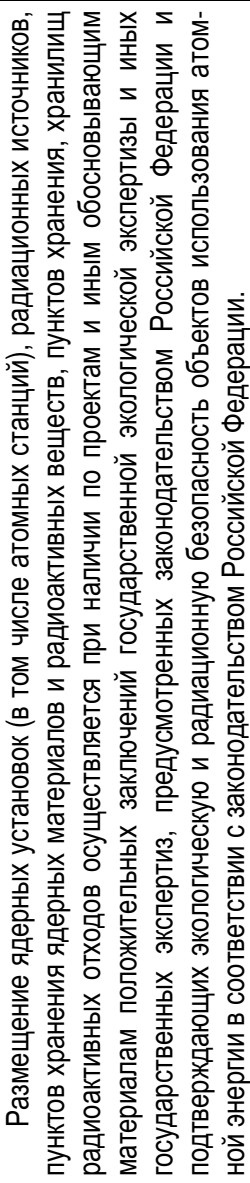 & 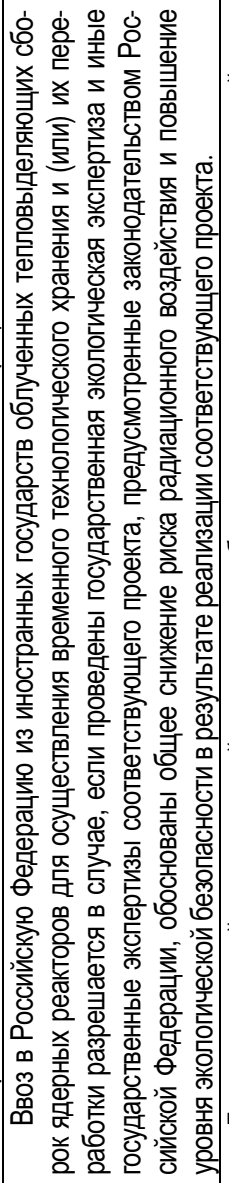 & 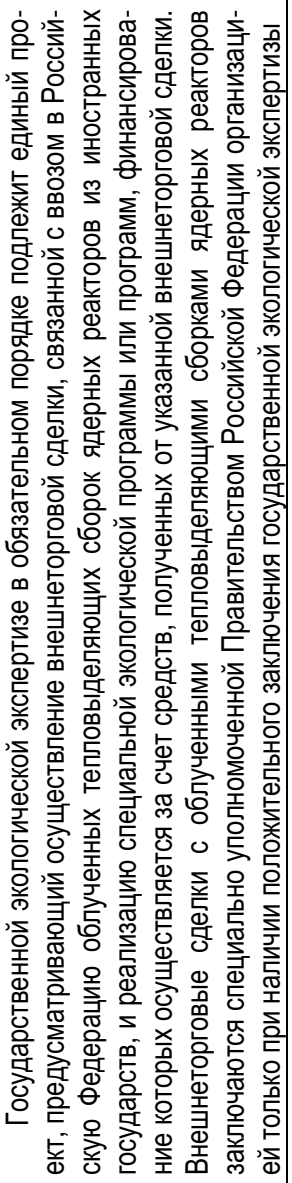 & 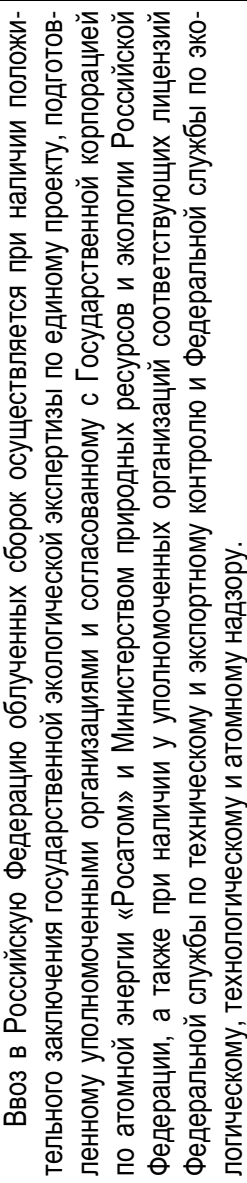 \\
\hline & 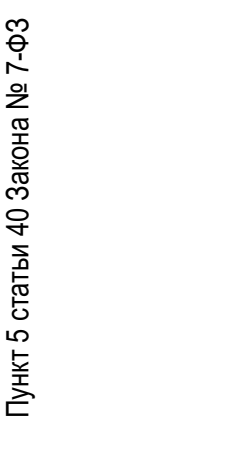 & 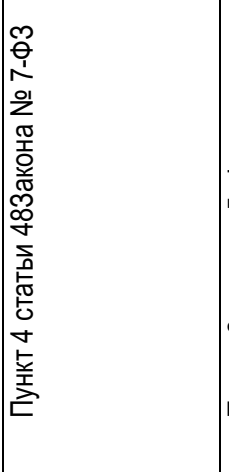 & 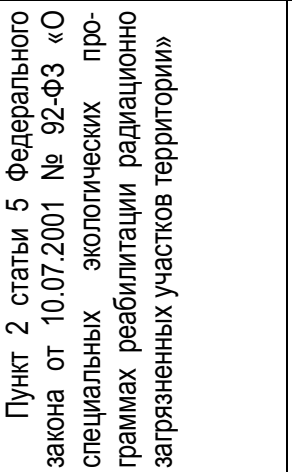 & 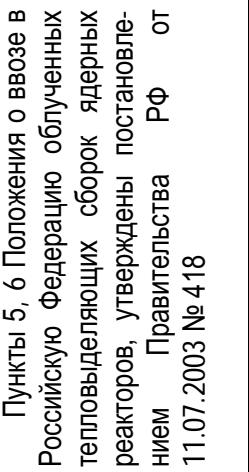 \\
\hline
\end{tabular}




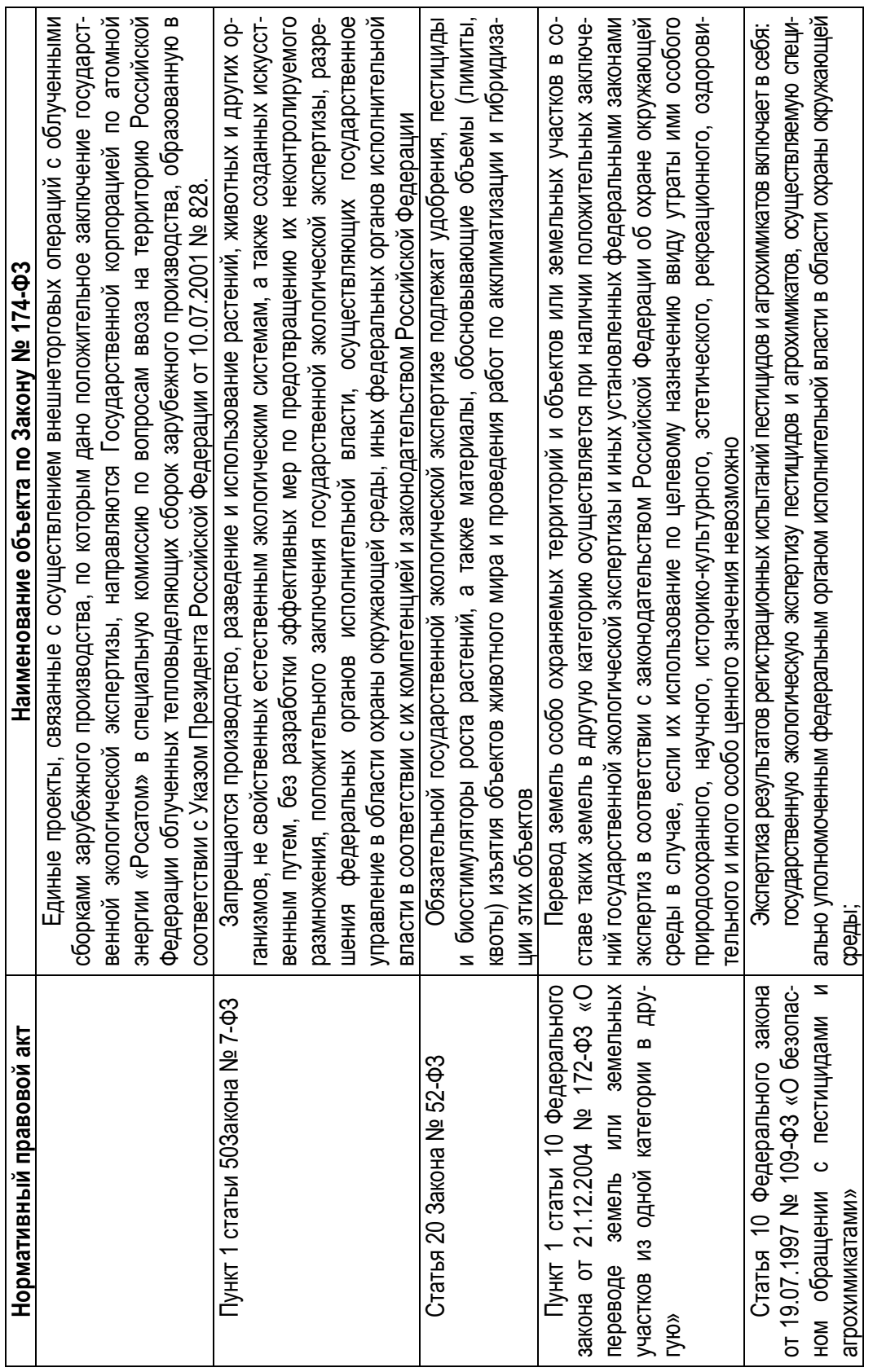




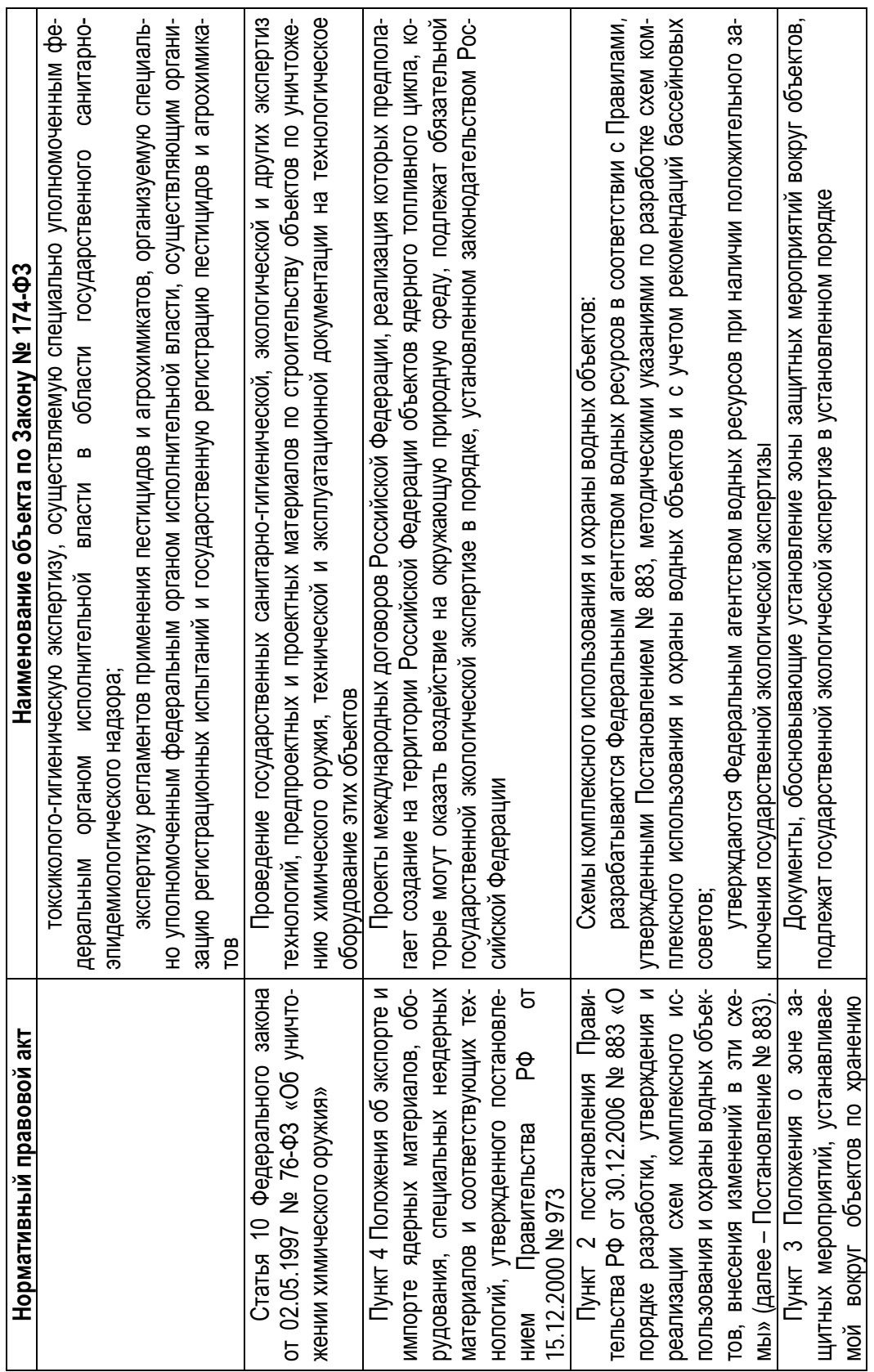




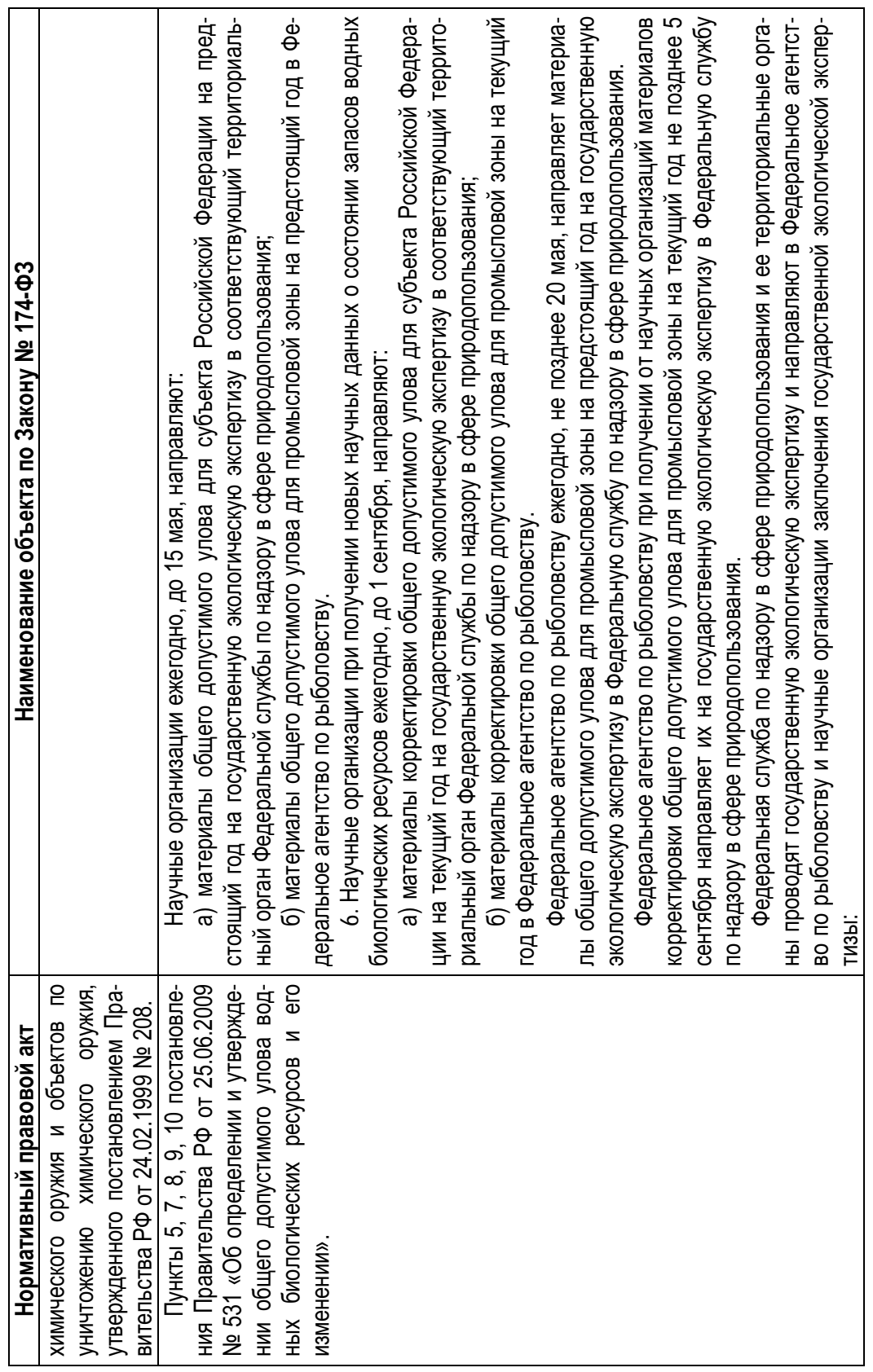




\begin{tabular}{|c|c|c|c|c|}
\hline 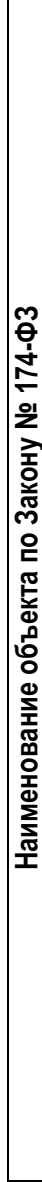 & 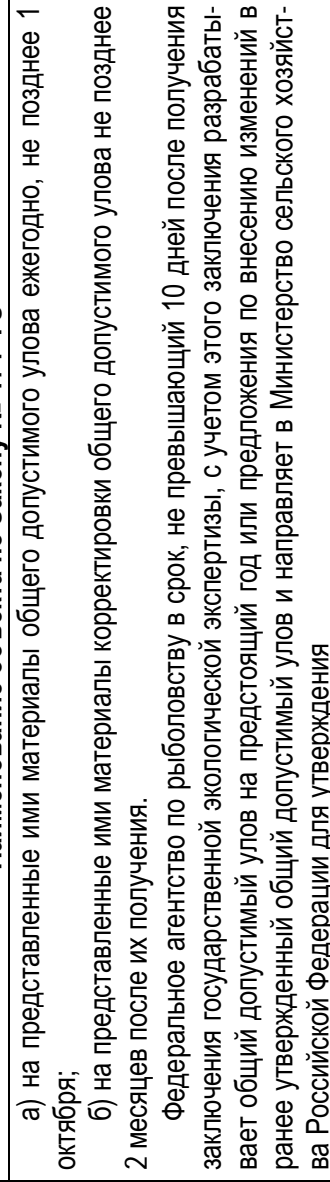 & 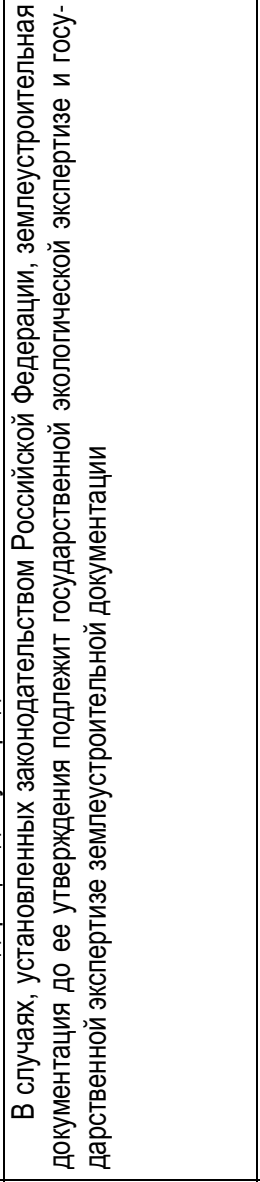 & 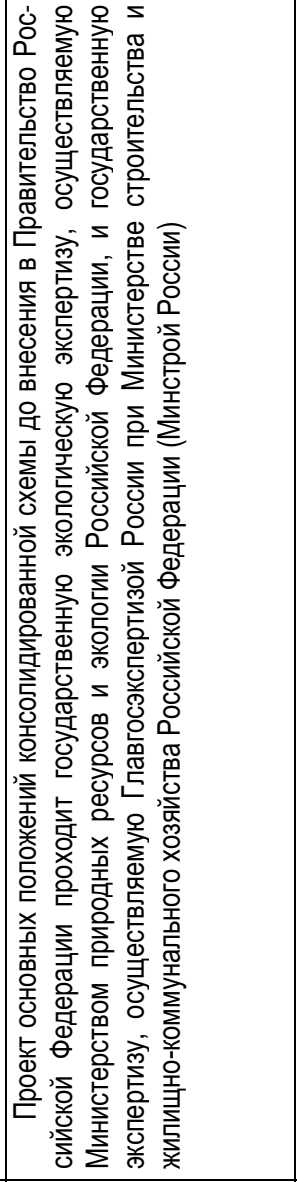 & 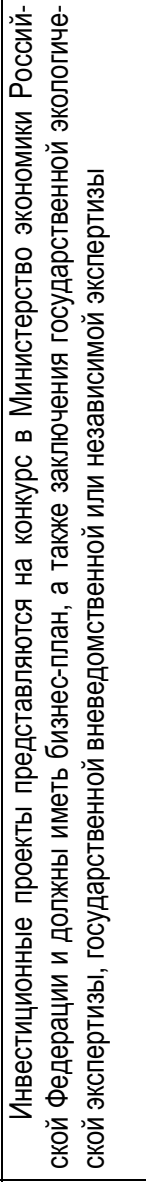 \\
\hline 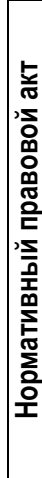 & & 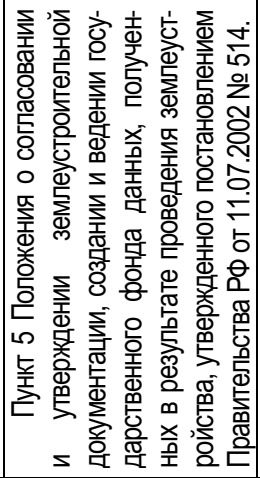 & 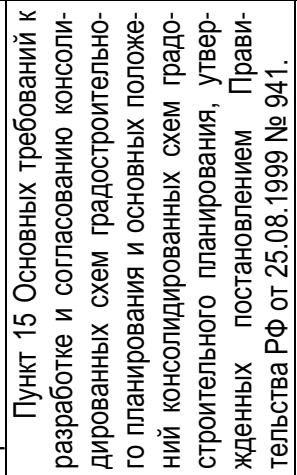 & 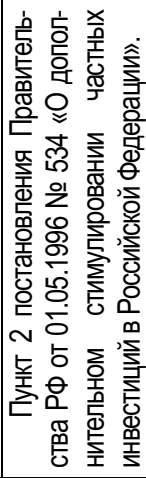 \\
\hline
\end{tabular}




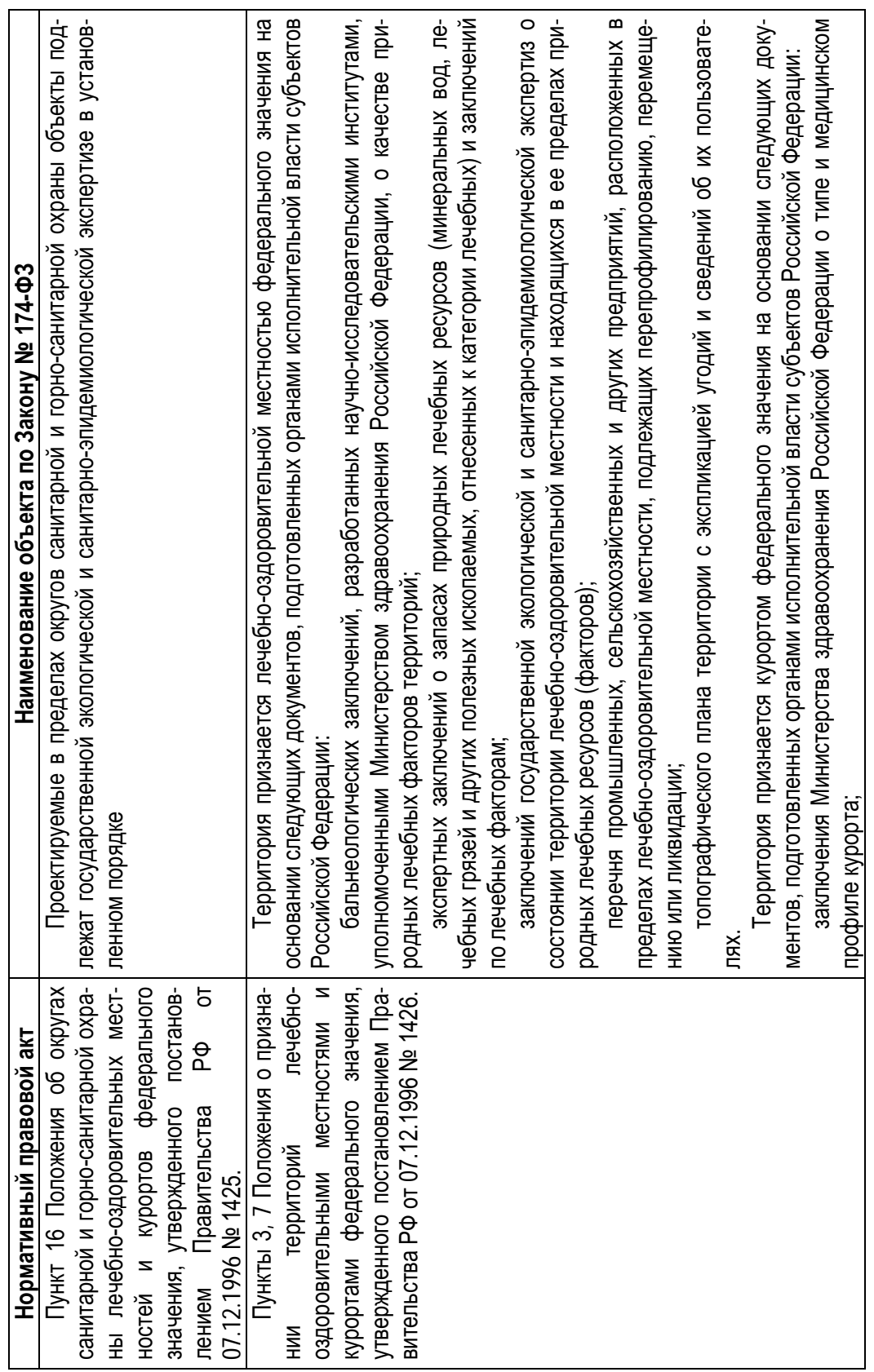




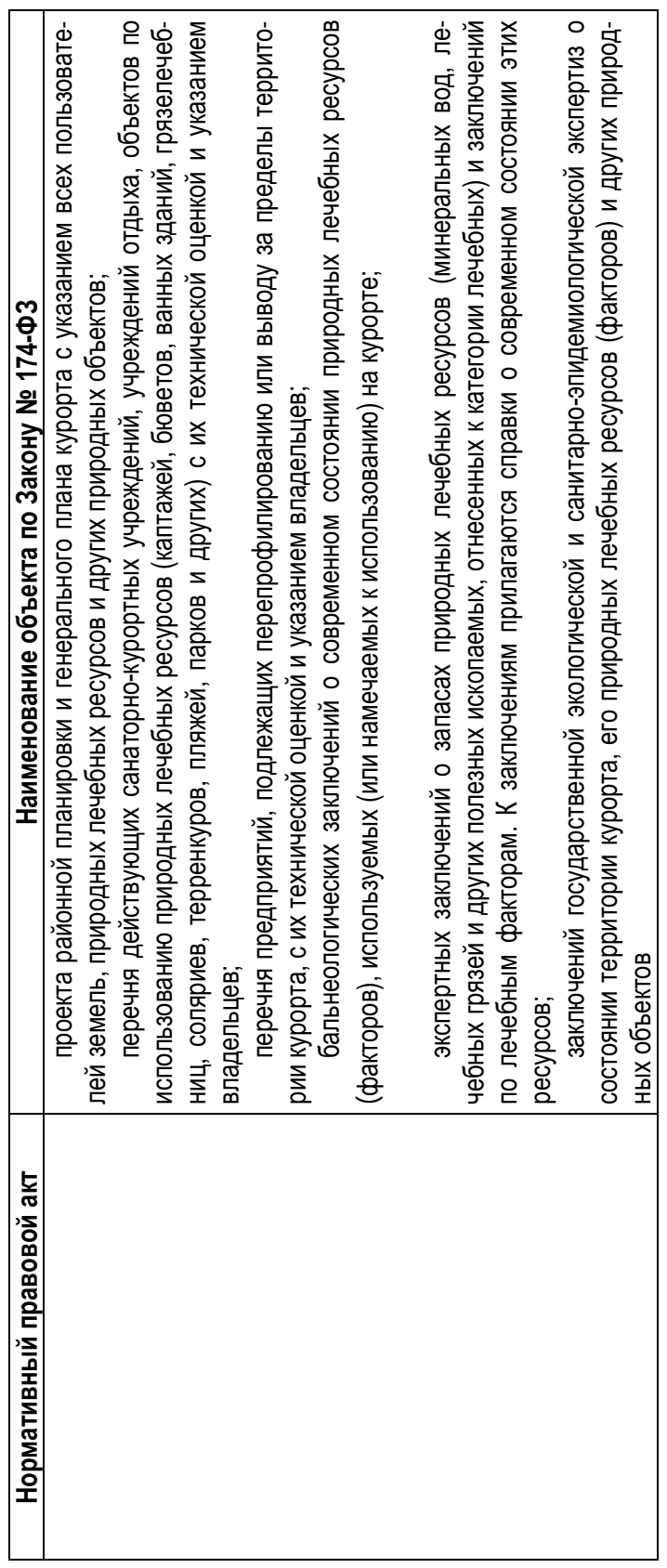




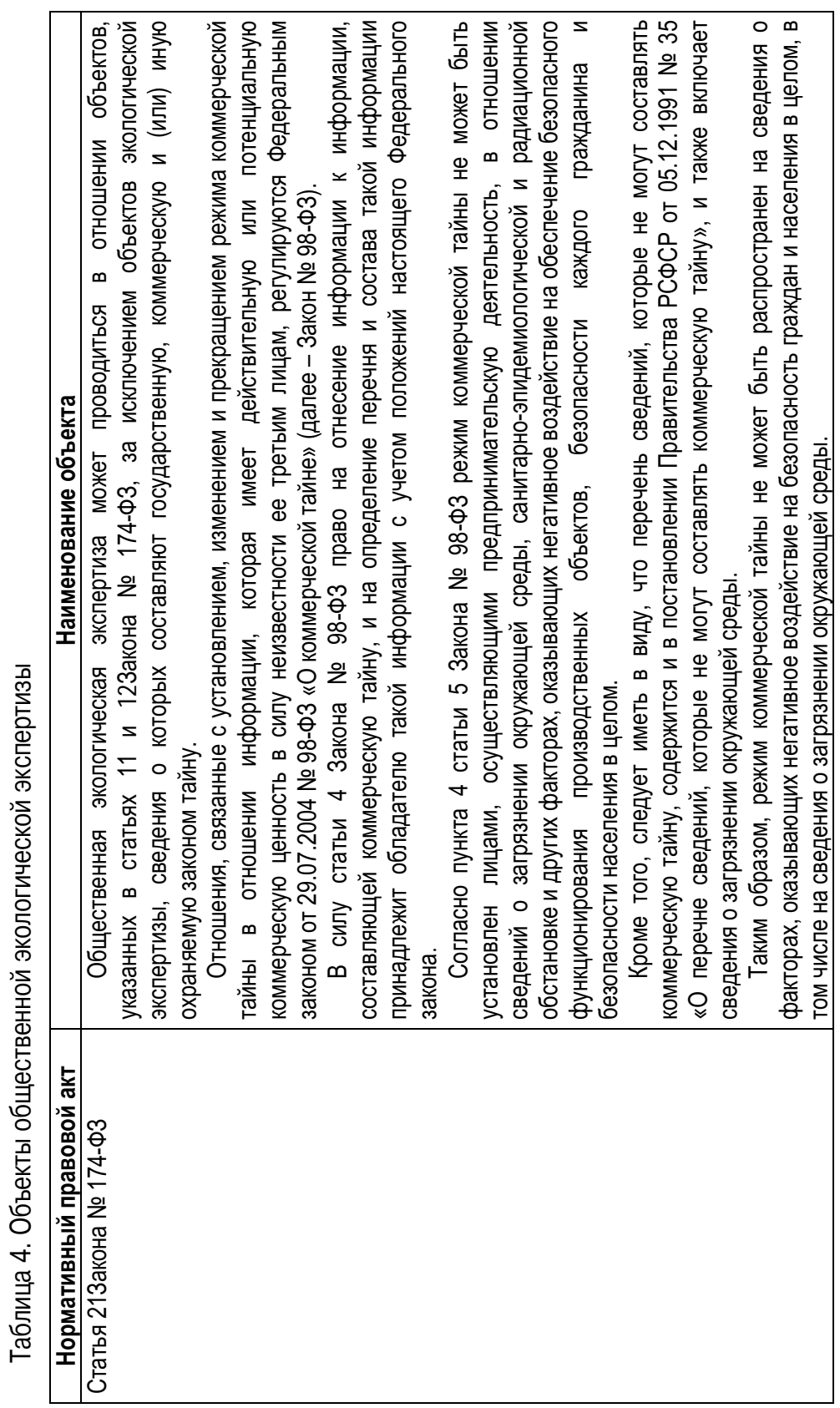




\section{5. Субъекты экологической экспертизы}

В Законе № 174-ФЗ выделены следующие самостоятельные субъекты экологической экспертизы:

1) орган государственной власти, уполномоченный на организацию и проведение государственной экологической экспертизы:

- федеральный орган исполнительной власти в области экологической экспертизы (статьи 5, 6, 10; абзац 6 пункта 1, абзац 7 пункта 1.1, пункт 2, абзац 2 пункта 3, пункт 5 статьи 14; статьи 15-19, 25-28, 30). Государственная экологическая экспертиза объектов федерального уровня организуется и проводится как центральным аппаратом Росприроднадзора, так и его территориальными органами;

- орган государственной власти субъектов РФ (статьи 6, 6.1, 9, 10, 12; абзац 6 пункта 1, абзац 7 пункта 1.1, абзац 2 пункта 3, пункт 5 статьи 14; статьи 15-19, 25-28, 30);

2) руководители органов государственной власти, уполномоченных на организацию и проведение государственной экологической экспертизы (часть 2 статьи 30):

- руководитель федерального органа исполнительной власти в области экологической экспертизы;

- руководитель органа государственной власти субъектов РФ;

2) экспертная комиссия, образованная федеральным органом исполнительной власти в области экологической экспертизы или органами государственной власти субъектов Российской Федерации для проведения государственной экологической экспертизы конкретного объекта, в состав которой включаются (пункт 5 статьи 14; статьи 15 и 18;пункт 2 статьи 19):

- руководитель экспертной комиссии;

- ответственный секретарь экспертной комиссии;

- внештатные эксперты - по согласованию с ними;

- штатные сотрудники федерального органа исполнительной власти в области экологической экспертизы и

- штатные сотрудники органов государственной власти субъектов Российской Федерации - в случаях, определенных нормативными правовыми актами федерального органа исполнительной власти в области экологической экспертизы;

3) эксперт государственной экологической экспертизы (статья 16; часть 3 статьи 30);

4) руководитель экспертной комиссии государственной экологической экспертизы (пункт 2 статьи 15; статья 17; пункт 3 статьи 18; часть 2 статьи 30; часть 3 статьи 30);

5) руководитель и члены экспертной комиссии общественной экологической экспертизы (пункт 3 статьи 25; статьи 30-34; часть 2 статьи 30; часть 3 статьи 30); 
6) заказчик документации, подлежащей государственной экологической экспертизе (пункт 5 статьи 6; пункты 1, 2, 4 статьи 14; пункты 6, 7 статьи 18; статьи 26 - 28; часть 1 статьи 30; статьи 33, 34):

- физическое или юридическое лицо;

- лицо, являющееся заказчиком в соответствии с Градостроительным кодексом РФ - при направлении материалов на государственную экологическую экспертизу объектов, указанных в пункте 7.1 статьи 11 и пункте 4.1 статьи 12 Закона № 174-ФЗ (абзац 6 пункта 1.1 статьи 14);

- лицо, с которым заключен государственный или муниципальный контракт на подготовку проектной документации искусственного земельного участка либо заключен договор о создании искусственного земельного участка - при направлении материалов на государственную экологическую экспертизу объектов, указанных в пункте 7.3 статьи 11 Закона № 174Ф3 (абзац 8 пункта 1.1 статьи 14);

7) федеральный орган исполнительной власти, орган исполнительной власти субъекта Российской Федерации, уполномоченные на проведение государственной экспертизы проектной документации, направляющие материалы государственной экологической экспертизы в отношении объектов, указанных в пунктах 7.1 и 7.3 статьи 11 и пункте 4.1 статьи 12 Закона № 174-Ф3 (абзац 1 пункта 1.1, пункт 4.1 статьи 14);

8) кредитные организации, их должностные лица, иные юридические лица, граждане, осуществляющие финансирование и кредитование реализации объекта государственной экологической экспертизы (пункт 6 статьи 18; абзац 6 статьи 27; часть 5 статьи 30);

9) заинтересованные лица (абзац 10 статьи 3; пункты 1 и 4 статьи 25; часть 1 статьи 30; статья 34);

10) орган местного самоуправления (статьи 9 и 14; абзац 6 пункта 5 статьи 16; пункт 6 статьи 18; статья 20; пункт 2 статьи 23; пункт 3 статьи 24; пункты 1 и 4 статьи 25; статья 29; часть 4 статьи 30);

11) должностные лица органов местного самоуправления (пункт 3 статьи 24; часть 4 статьи 30; статья 33);

12) должностные лица государственных органов (часть 4 статьи 30; статья 33);

13) граждане и общественные организации в области экологической экспертизы (преамбула; статья 3; абзац 5 пункта 1 статьи 14; статьи 19, 20 , 22 - 24, 29; часть 5 статьи 30; статья 34);

14) консультанты экологической экспертизы и иные работники (статья 33).

В общем виде субъектов экологической экспертизы можно представить следующим образом.

Субъекты государственной экологической экспертизы:

1) непосредственные участники государственной экологической экспертизы: 
- орган государственной власти, уполномоченный на организацию и проведение государственной экологической экспертизы (его руководитель);

- экспертная комиссия (руководитель экспертной комиссии, эксперты государственной экологической экспертизы);

- заказчик документации, подлежащей государственной экологической экспертизе;

2) иные лица:

- иные федеральные органы исполнительной власти и органы государственной власти субъектов РФ (их руководители, должностные лица);

- органы местного самоуправления (руководитель, должностные лица);

- кредитные организации, их должностные лица, иные юридические лица, граждане, осуществляющие финансирование и кредитование реализации объекта государственной экологической экспертизы;

- заинтересованные лица;

- граждане и общественные организации в области экологической экспертизы.

Субъекты общественной экологической экспертизы:

1) непосредственные участники общественной экологической экспертизы:

- общественные организации (объединения), основным направлением деятельности которых в соответствии с их уставами является охрана окружающей среды, в том числе организация и проведение экологической экспертизы, и которые зарегистрированы в порядке, установленном законодательством Российской Федерации;

- экспертная комиссия;

- эксперты, привлекаемые для проведения общественной экологической экспертизы;

- федеральный орган исполнительной власти в области экологической экспертизы или орган государственной власти субъекта Российской Федерации;

- заказчик документации, подлежащей общественной экологической экспертизе: граждане и общественные организации; органы местного самоуправления;

2) иные лица:

- органы, принимающие решение о реализации объектов экологической экспертизы;

- органы местного самоуправления;

- заинтересованные лица.

Закон № 174-ФЗ в качестве самостоятельных субъектов экологической экспертизы выделяет:

- заказчиков документации, подлежащей экологической экспертизе;

- заинтересованных лиц; 
- юридических лиц и граждан, осуществляющих финансирование реализации объекта экологической экспертизы, вместе с тем не раскрывает их содержание.

Понятие «заказчик документации, подлежащей экологической экспертизе» в Законе № 173-ФЗ не раскрыто. В связи с этим встают вопросы:

1) кто уполномочен подавать в специальной уполномоченный орган государственной власти документы, подлежащие экологической экспертизе: заказчик предстоящих работ или нанятое им по соответствующему гражданско-правовому договору на осуществление определенных действий в разработке соответствующих материалов и представления их на государственную экологическую экспертизу иное лицо.

2) кто будет нести ответственность за непредставление документации на экологическую экспертизу или представление на экологическую экспертизу недостоверных сведений - заказчик предстоящих работ или иное лицо? По поводу возникающих вопросов возникала и противоречивая правоприменительная практика.

Пункт 5 Положения о порядке проведения государственной экологической экспертизы, утвержденного постановлением Правительства РФ от 11.06.1996 № 6987 , понимает под заказчиком физическое или юридическое лицо, представляющее материалы на государственную экологическую экспертизу. Определение конкретное, предполагающее за собой лицо, непосредственно обратившееся с соответствующим заявлением в уполномоченный орган исполнительной власти. Положение об оценке воздействия намечаемой хозяйственной и иной деятельности на окружающую среду в Российской Федерации, утвержденное приказом Госкомэкологии РФ от 16.05.2000 № 372, под заказчиками понимает «юридических и физических лиц, отвечающих за подготовку документации по намечаемой деятельности в соответствии с нормативными требованиями, предъявляемыми к данному виду деятельности, и представляющие документацию по намечаемой деятельности на экологическую экспертизу».

Административный регламент Федеральной службы по надзору в сфере природопользования по предоставлению государственной услуги по организации и проведению государственной экологической экспертизы федерального уровня, утвержденный приказом Минприроды РФ от 06.05.2014 № 204 (далее - Регламент № 204) согласно пункту 2 заявителями при предоставлении государственной услуги по организации и проведению государственной экологической экспертизы являются физические, юридические лица либо их уполномоченные представители, обратившиеся с заявлением о предоставлении государственной услуги.

\footnotetext{
${ }^{7}$ В настоящее время постановление отменено.
} 
Закон № 174-ФЗ категорию «заказчик документации, подлежащей государственной экологической экспертизе»раскрыл только для отдельных объектов государственной экологической экспертизы.

В силу требований абзаца 6 пункта 1.1 статьи 14 Закона № 174-Ф3 правами и обязанностями заказчика документации, подлежащей государственной экологической экспертизы, обладает лицо, являющееся заказчиком в соответствии с Градостроительным кодексом РФ. Указанное положение применимо при направлении материалов на государственную экологическую экспертизу объектов, указанных в пункте 7.1 статьи 11 (проектная документация объектов, строительство, реконструкцию которых предполагается осуществлять на землях особо охраняемых природных территорий федерального значения, на Байкальской природной территории, а также проектная документация особо опасных, технически сложных и уникальных объектов, объектов обороны и безопасности, строительство, реконструкцию которых предполагается осуществлять на землях особо охраняемых природных территорий регионального и местного значения, в случаях, если строительство, реконструкция таких объектов на землях особо охраняемых природных территорий допускаются законодательством Российской Федерации и законодательством субъектов Российской Федерации) и пункте 4.1 статьи 12 Закона № 174-Ф3(проектная документация объектов, строительство, реконструкцию которых предполагается осуществлять на землях особо охраняемых природных территорий регионального и местного значения, за исключением проектной документации объектов, указанных в пункте 7.1 статьи 11 Закона № 174-Ф3, в соответствии с законодательством Российской Федерации и законодательством субъектов Российской Федерации).

Градостроительный кодекс РФ содержит определения:

- застройщик - физическое или юридическое лицо, обеспечивающее на принадлежащем ему земельном участке или на земельном участке иного правообладателя (которому при осуществлении бюджетных инвестиций в объекты капитального строительства государственной (муниципальной) собственности органы государственной власти (государственные органы), Государственная корпорация по атомной энергии «Росатом», Государственная корпорация по космической деятельности «Роскосмос», органы управления государственными внебюджетными фондами или органы местного самоуправления передали в случаях, установленных бюджетным законодательством Российской Федерации, на основании соглашений свои полномочия государственного (муниципального) заказчика) строительство, реконструкцию, капитальный ремонт объектов капитального строительства, а также выполнение инженерных изысканий, подготовку проектной документации для их строительства, реконструкции, капитального ремонта. Заст- 
ройщик вправе передать свои функции, предусмотренные законодательством о градостроительной деятельности, техническому заказчику (пункт 16 статьи 1);

- технический заказчик - юридическое лицо, которое уполномочено застройщиком и от имени застройщика заключает договоры о выполнении инженерных изысканий, о подготовке проектной документации, о строительстве, реконструкции, капитальном ремонте объектов капитального строительства, подготавливает задания на выполнение указанных видов работ, предоставляет лицам, выполняющим инженерные изыскания и (или) осуществляющим подготовку проектной документации, строительство, реконструкцию, капитальный ремонт объектов капитального строительства, материалы и документы, необходимые для выполнения указанных видов работ, утверждает проектную документацию, подписывает документы, необходимые для получения разрешения на ввод объекта капитального строительства в эксплуатацию, осуществляет иные функции, предусмотренные законодательством о градостроительной деятельности (далее - функции технического заказчика). Функции технического заказчика могут выполняться только членом соответственно саморегулируемой организации в области инженерных изысканий, архитектурно-строительного проектирования, строительства, реконструкции, капитального ремонта объектов капитального строительства, за исключением случаев, предусмотренных частью 2.1 статьи 47, частью 4.1 статьи 48, частью 2.2 статьи 52 Градостроительного кодекса РФ (пункт 22 статьи 1);

- лицами, выполняющими инженерные изыскания, могут являться застройщик, лицо, получившее в соответствии с Земельным кодексом Российской Федерации разрешение на использование земель или земельного участка, находящегося в государственной или муниципальной собственности, для выполнения инженерных изысканий, либо индивидуальный предприниматель или юридическое лицо, заключившие договор подряда на выполнение инженерных изысканий. Лицо, выполняющее инженерные изыскания, несет ответственность за полноту и качество инженерных изысканий и их соответствие требованиям технических регламентов. Застройщик или лицо, получившее в соответствии с Земельным кодексом Российской Федерации разрешение на использование земель или земельного участка, находящегося в государственной или муниципальной собственности, для выполнения инженерных изысканий, вправе выполнить инженерные изыскания самостоятельно при условии, что такие лица являются членами саморегулируемой организации в области инженерных изысканий, или с привлечением иных лиц по договору подряда на выполнение инженерных изысканий (часть 3 статьи 47); 
- лицом, осуществляющим подготовку проектной документации, может являться застройщик либо индивидуальный предприниматель или юридическое лицо, заключившие договор подряда на подготовку проектной документации. Лицо, осуществляющее подготовку проектной документации, несет ответственность за качество проектной документации и ее соответствие требованиям технических регламентов. Застройщик вправе выполнить подготовку проектной документации самостоятельно при условии, что он является членом саморегулируемой организации в области архитектурно-строительного проектирования, либо с привлечением иных лиц по договору подряда на подготовку проектной документации (часть 5 статьи 48).

Работы по договорам о подготовке проектной документации, заключенным с застройщиком, техническим заказчиком, лицом, ответственным за эксплуатацию здания, сооружения, региональным оператором (далее также - договоры подряда на подготовку проектной документации), должны выполняться только индивидуальными предпринимателями или юридическими лицами, которые являются членами саморегулируемых организаций в области архитектурно-строительного проектирования, если иное не предусмотрено настоящей статьей. Выполнение работ по подготовке проектной документации по таким договорам обеспечивается специалистами по организации архитектурно-строительного проектирования (главными инженерами проектов, главными архитекторами проектов). Работы по договорам о подготовке проектной документации, заключенным с иными лицами, могут выполняться индивидуальными предпринимателями или юридическими лицами, не являющимися членами таких саморегулируемых организаций (часть 4 статьи 48).

В соответствии с абзацем 8 пункта 1.1 статьи 14 Закона № 174-Ф3 правами и обязанностями заказчика документации, подлежащей государственной экологической экспертизе, обладает лицо, с которым заключен государственный или муниципальный контракт на подготовку проектной документации искусственного земельного участка либо заключен договор о создании искусственного земельного участка. Указанное положение применимо при направлении материалов на государственную экологическую экспертизу объектов, указанных в пункте 7.3 статьи 11 Закона № 174-Ф3 (проектная документация искусственных земельных участков, создание которых предполагается осуществлять на водных объектах, находящихся в собственности Российской Федерации).

Законодатель получение положительного заключения государственной экологической экспертизы связывает не с субъектом - заказчиком намечаемой хозяйственной деятельности, а с хозяйственной деятельностью в целом, оказывающей воздействие на окружающую среду. Это следует из требований как специального закона -Закона № 174-Ф3, так 
и общего закона - Закона № 7-ФЗ. Согласно статьи 3 Закона № 7-Ф3 хозяйственная и иная деятельность юридических и физических лиц, оказывающая воздействие на окружающую среду, должна осуществляться на основе обязательности проведения государственной экологической экспертизы проектов и иной документации, обосновывающих хозяйственную и иную деятельность, которая может оказать негативное воздействие на окружающую среду, создать угрозу жизни, здоровью и имуществу граждан.

Исходя из указанного, под определение «заказчик документации, подлежащей государственной экологической экспертизы» подпадают не только непосредственные заявители (лица, обратившиеся в уполномоченный орган с соответствующим заявлением), но и иные лица (заказчики соответствующих работ, уполномоченные заказчиками лица).

Закон № 174-ФЗ в статье 30 определяет субъектов экологической экспертизы, которые могут стать субъектами правонарушений:

Часть 1 включает в себя 7 видов нарушений, субъектами которых выступают заказчики документации и заинтересованные лица.

Часть 2 статьи 30 включает в себя 6 видов нарушений, субъектами которых являются руководители федерального органа исполнительной власти и органов государственной власти субъектов Российской Федерации и руководители экспертных комиссий государственной экологической экспертизы.

Часть 3 статьи 30 включает в себя 4 вида нарушений, субъектами которых являются руководители экспертной комиссии экологической экспертизы и эксперты экологической экспертизы.

Часть 4 статьи 30 включает в себя 5 видов нарушений, субъектами которых выступают должностные лица государственных органов, а также органов местного самоуправления.

Часть 5 статьи 30 включает в себя одно нарушение, субъектами которых выступают кредитные организации, их должностные лица, иные юридические лица, а также граждане, которые осуществляют финансирование и кредитование реализации объекта экологической экспертизы без положительного заключения государственной экологической экспертизы.

Во всех случаях при привлечении к административной ответственности необходимо установить статус субъекта административного правонарушения. Установление статуса субъекта включает два момента:

- подтверждение того факта, что за данное нарушение ответственность по закону несет именно данная категория субъектов и

- подтверждение того, что конкретное лицо на основании соответствующих документов (приказов, положений, инструкции и др.) относится именно к этой категории субъектов. 


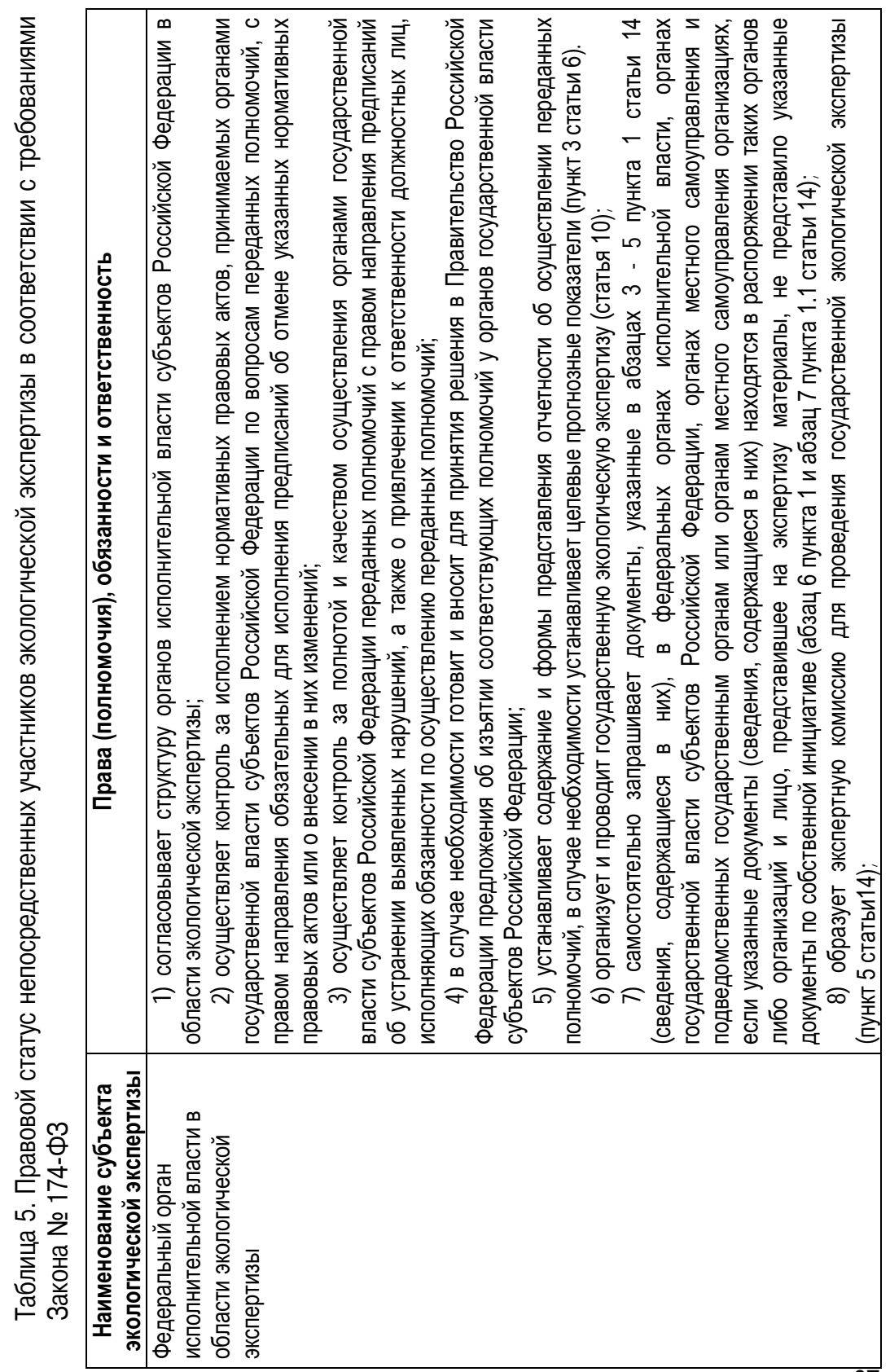




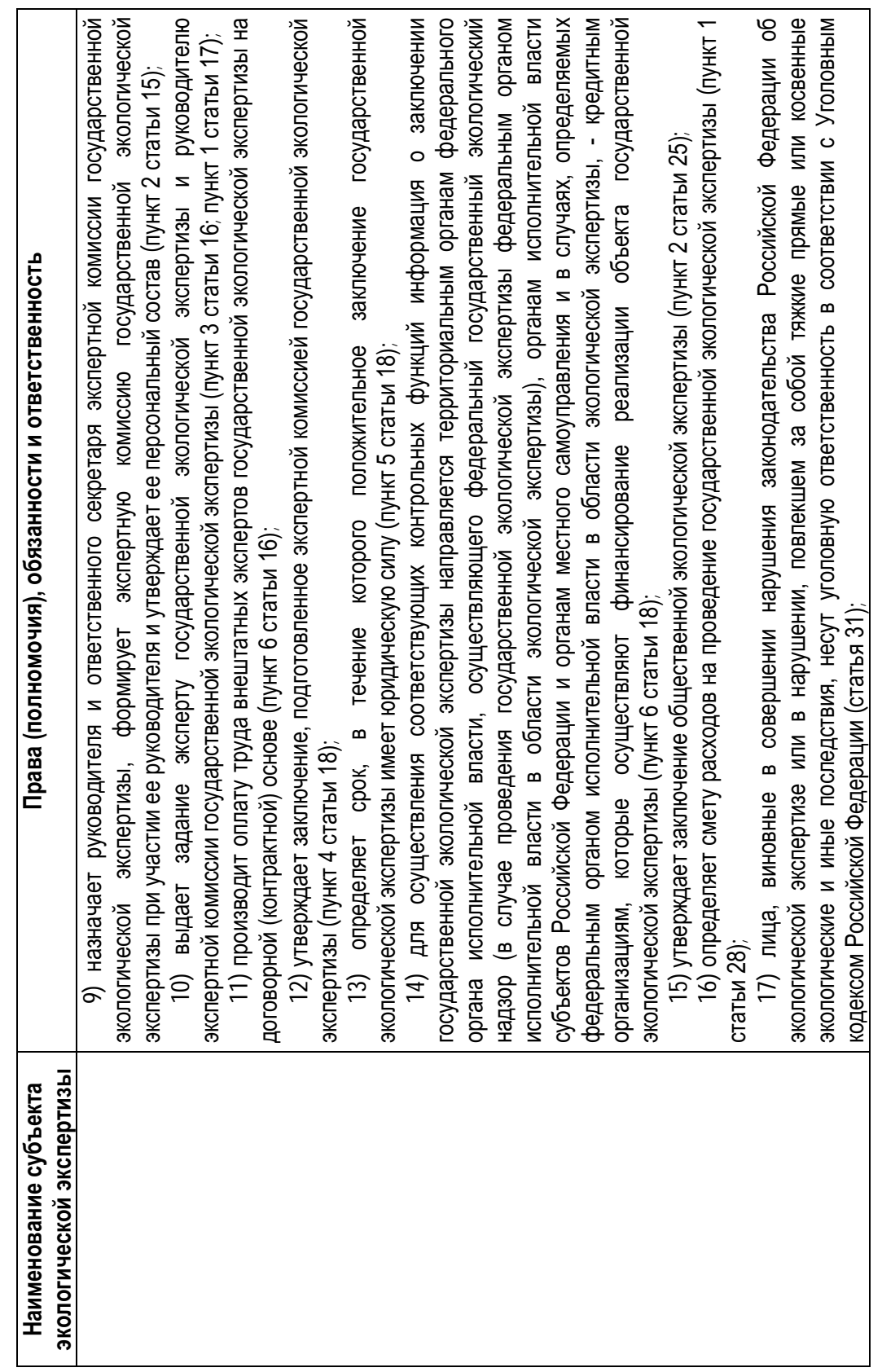




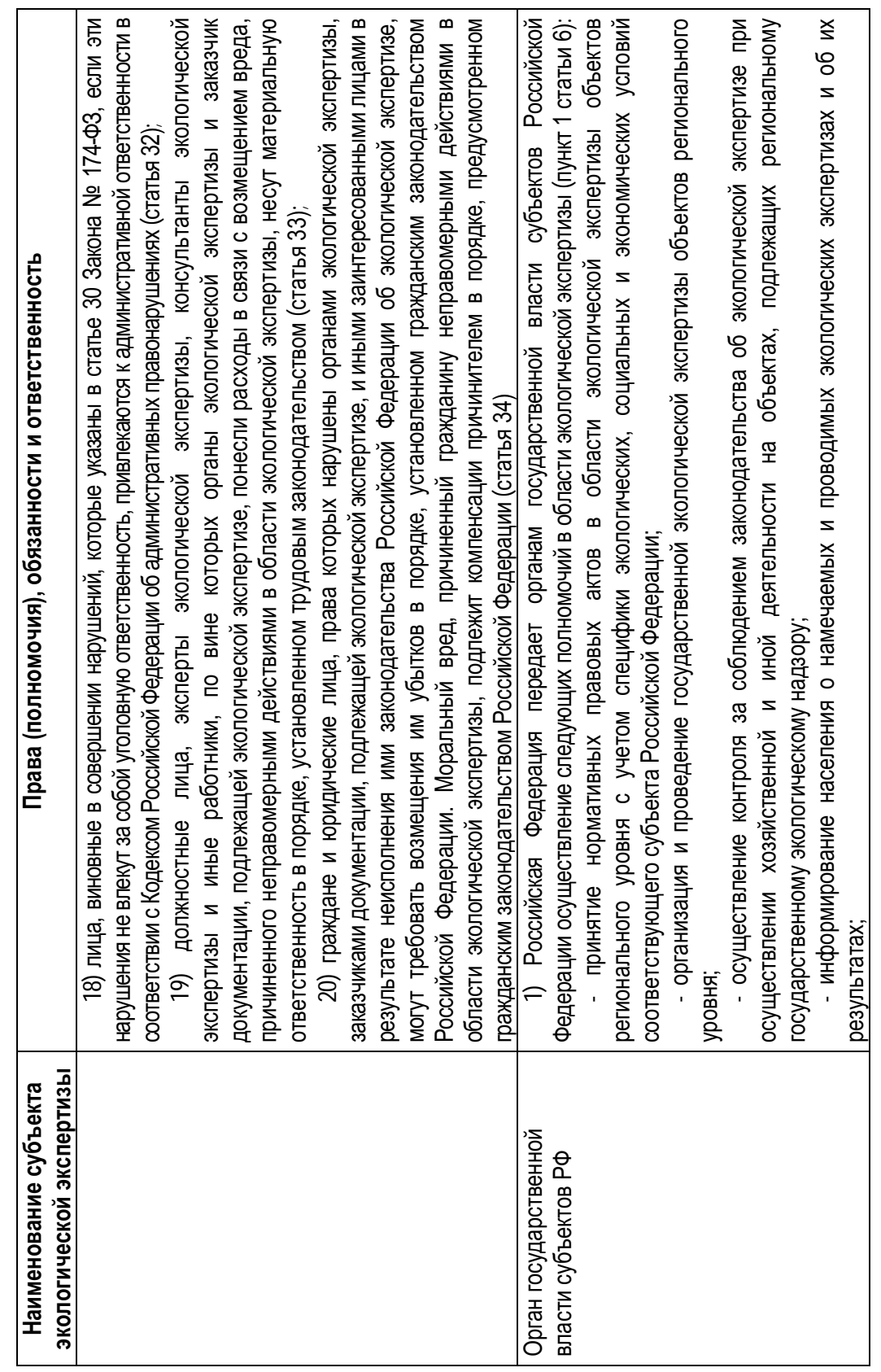




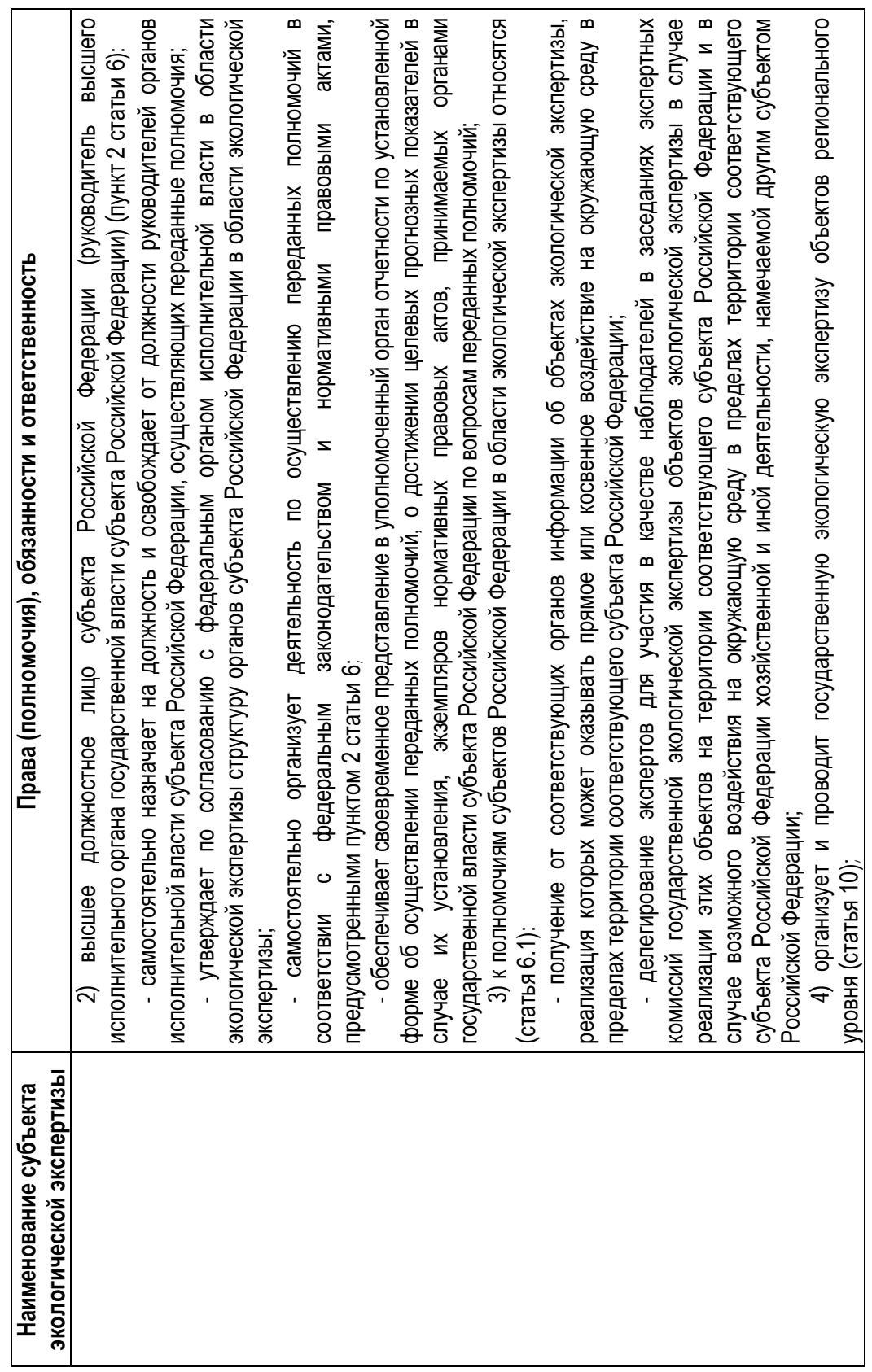




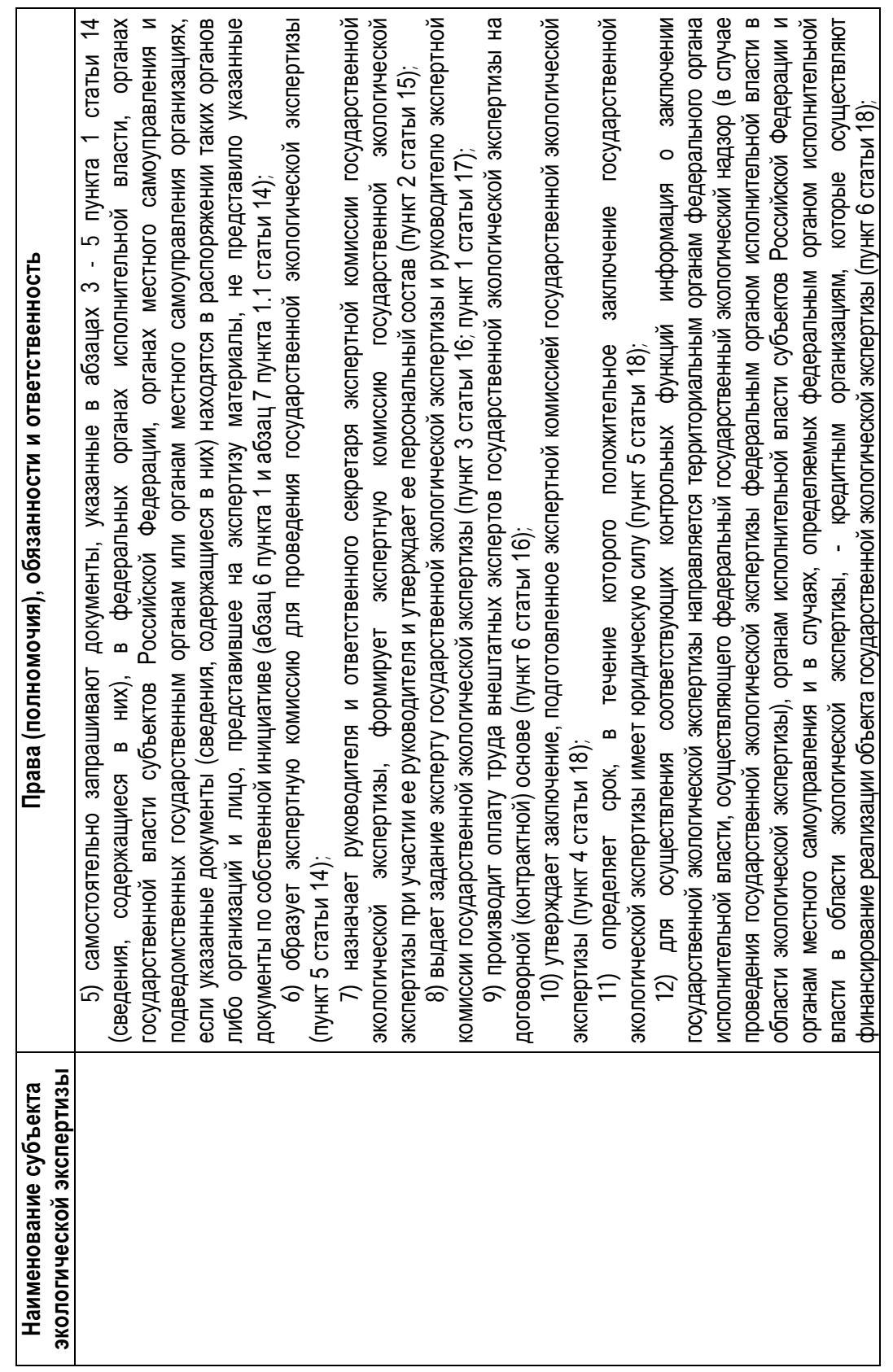




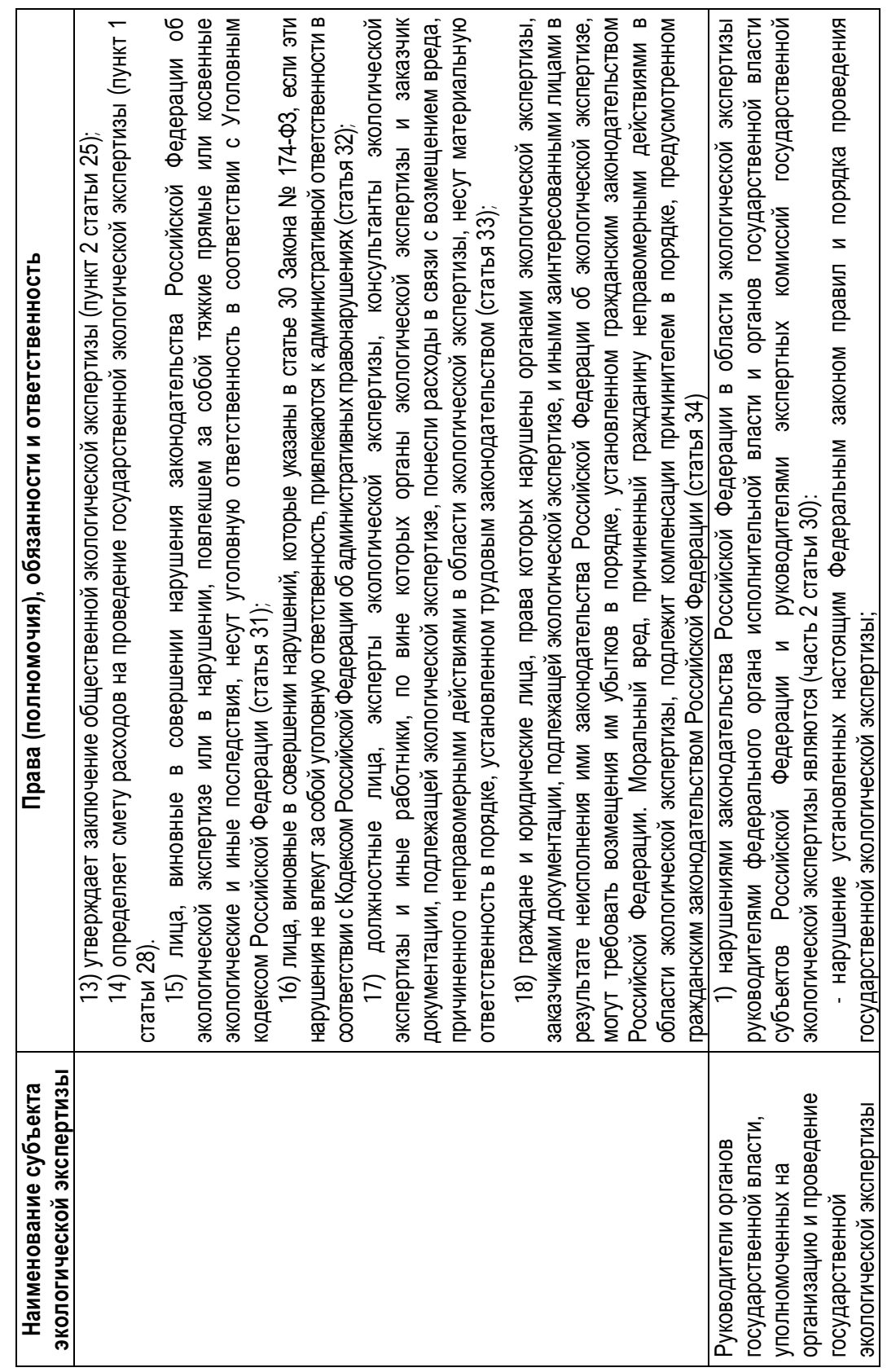




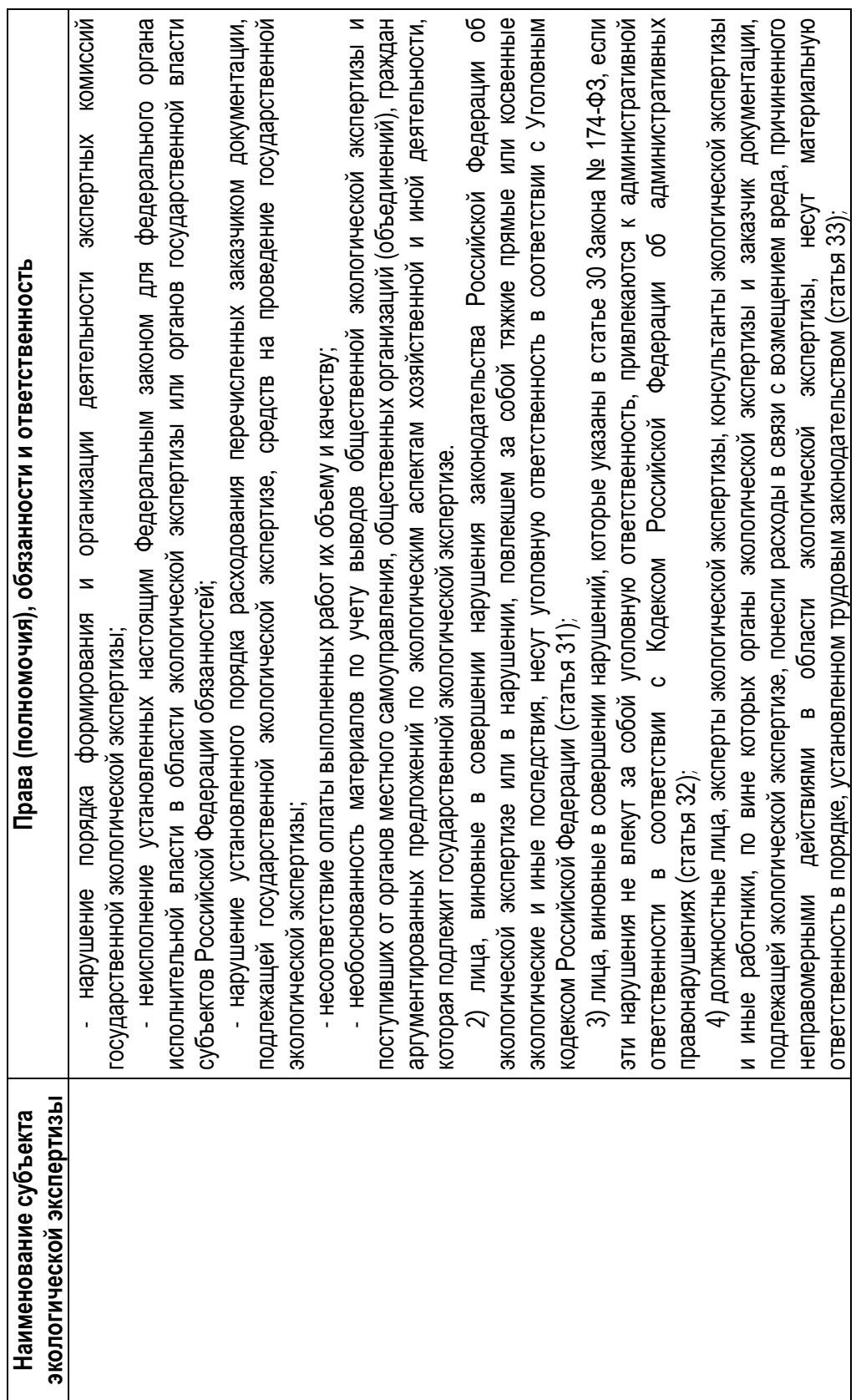




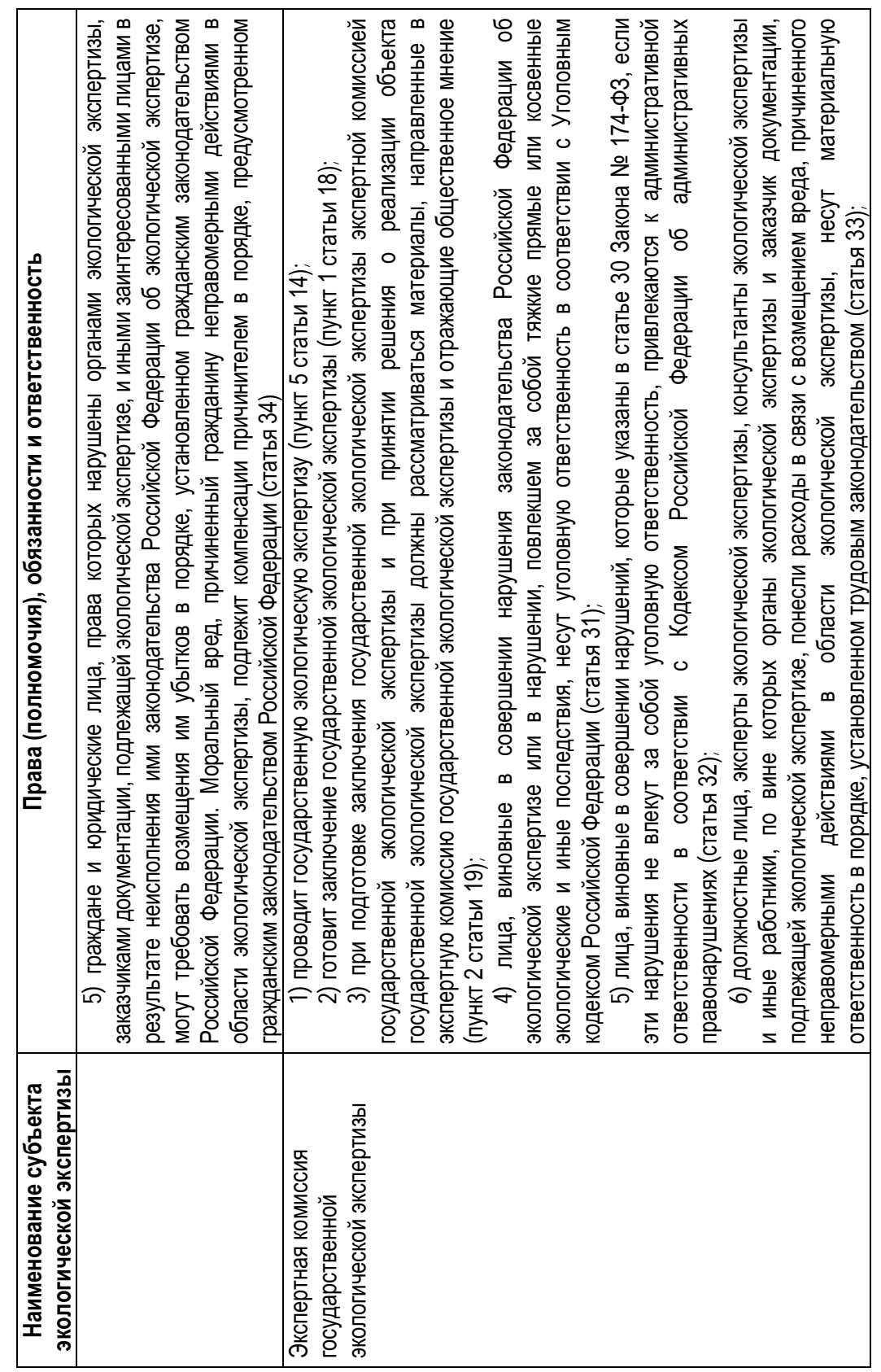




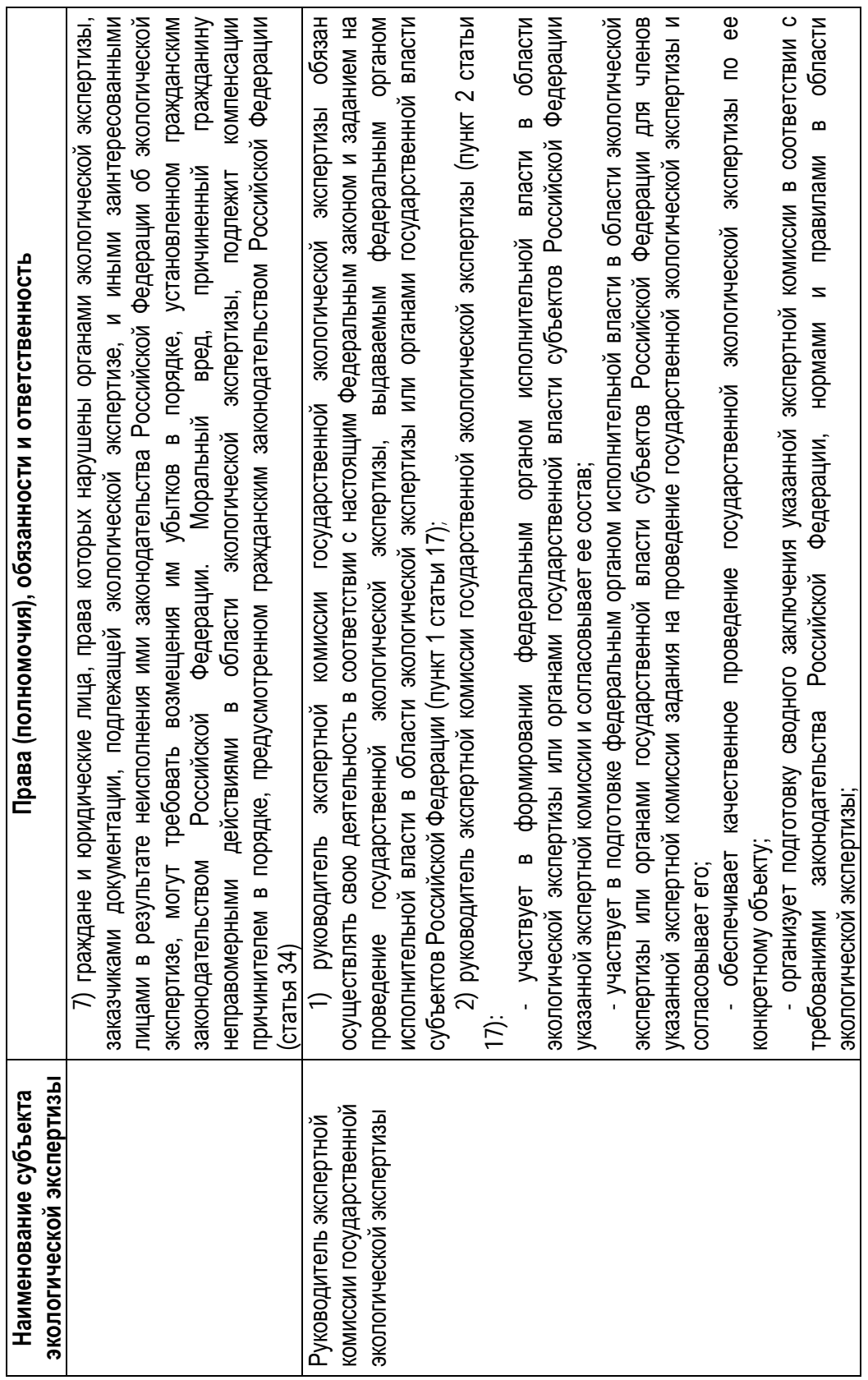




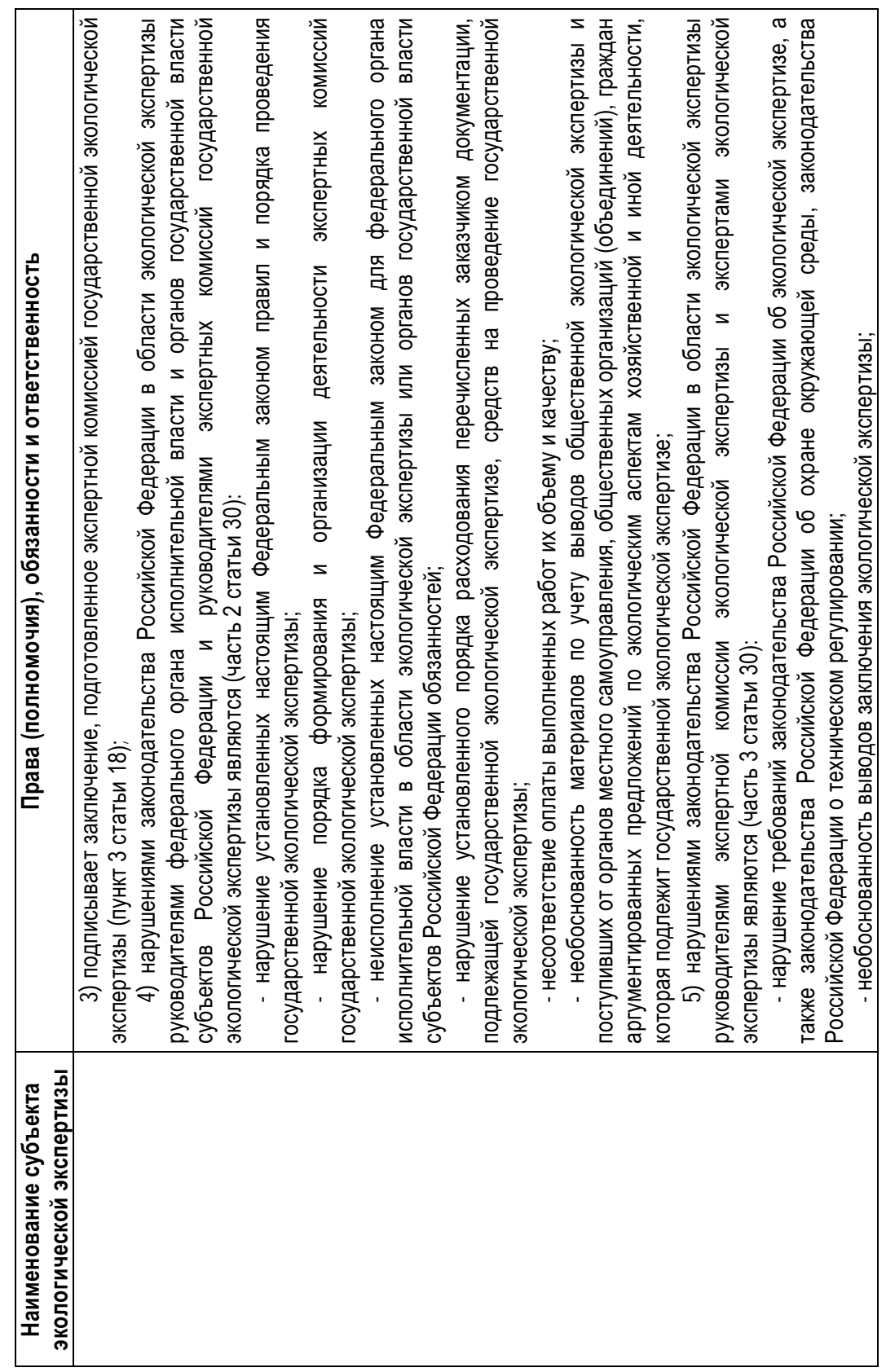




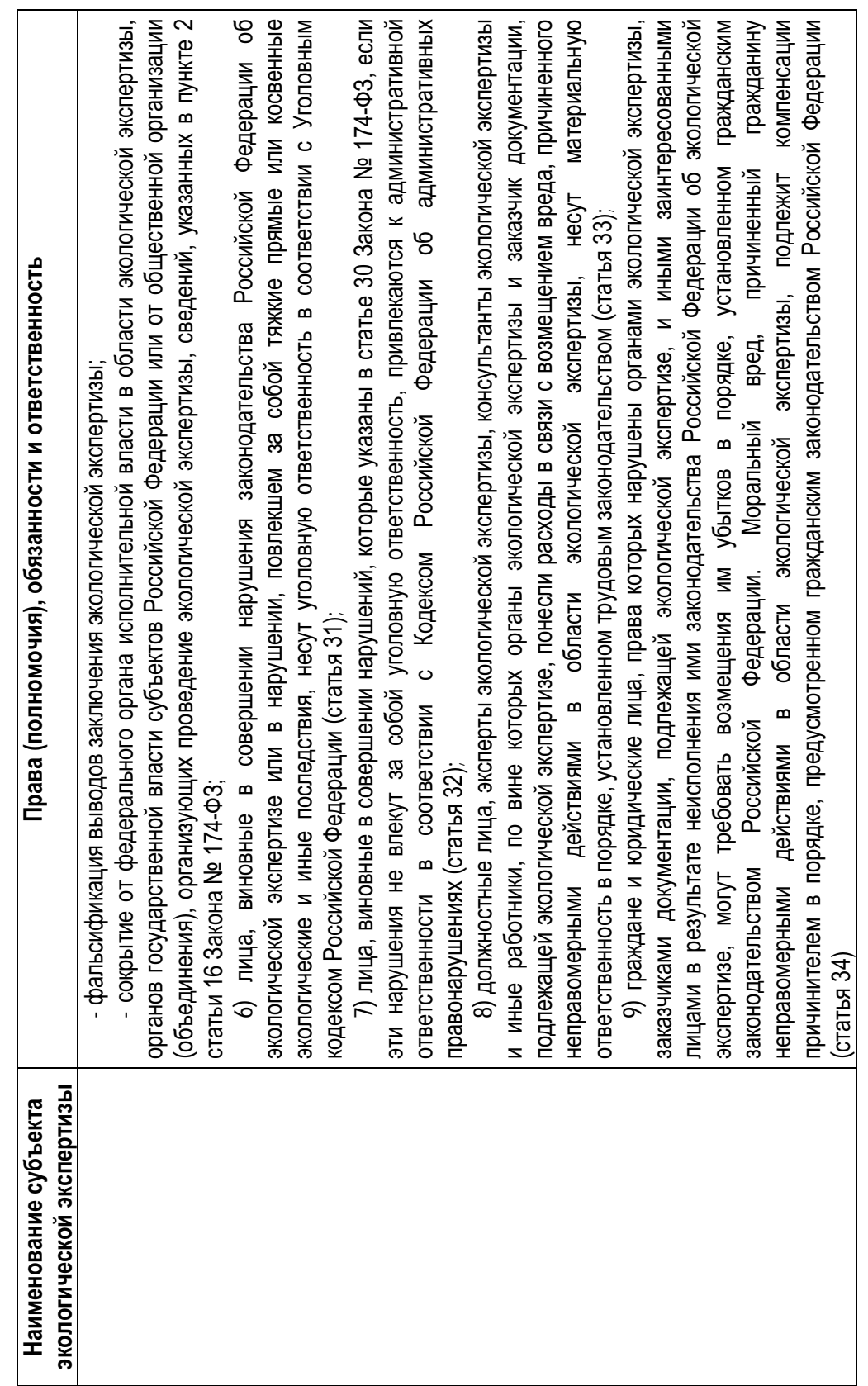




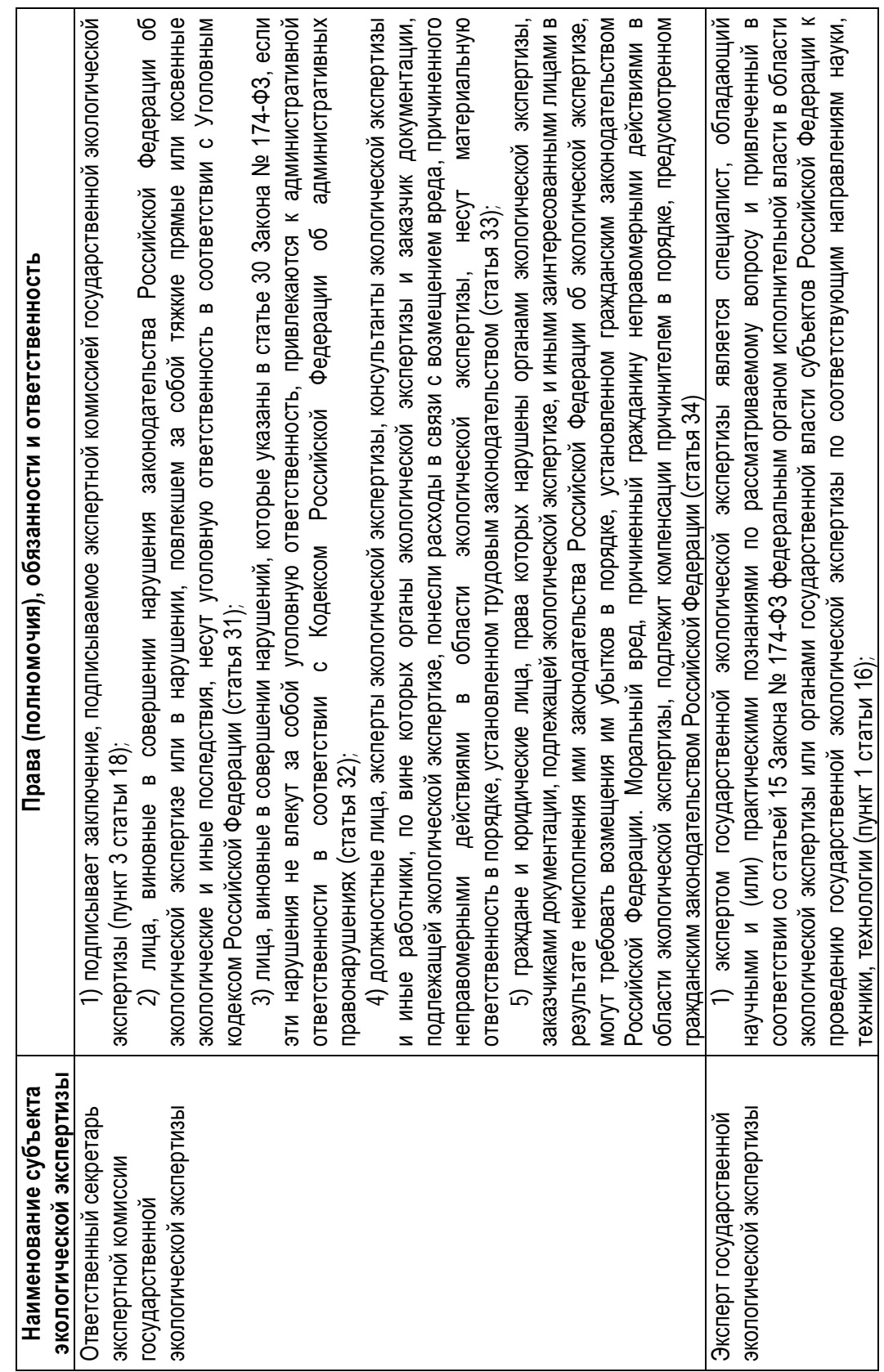




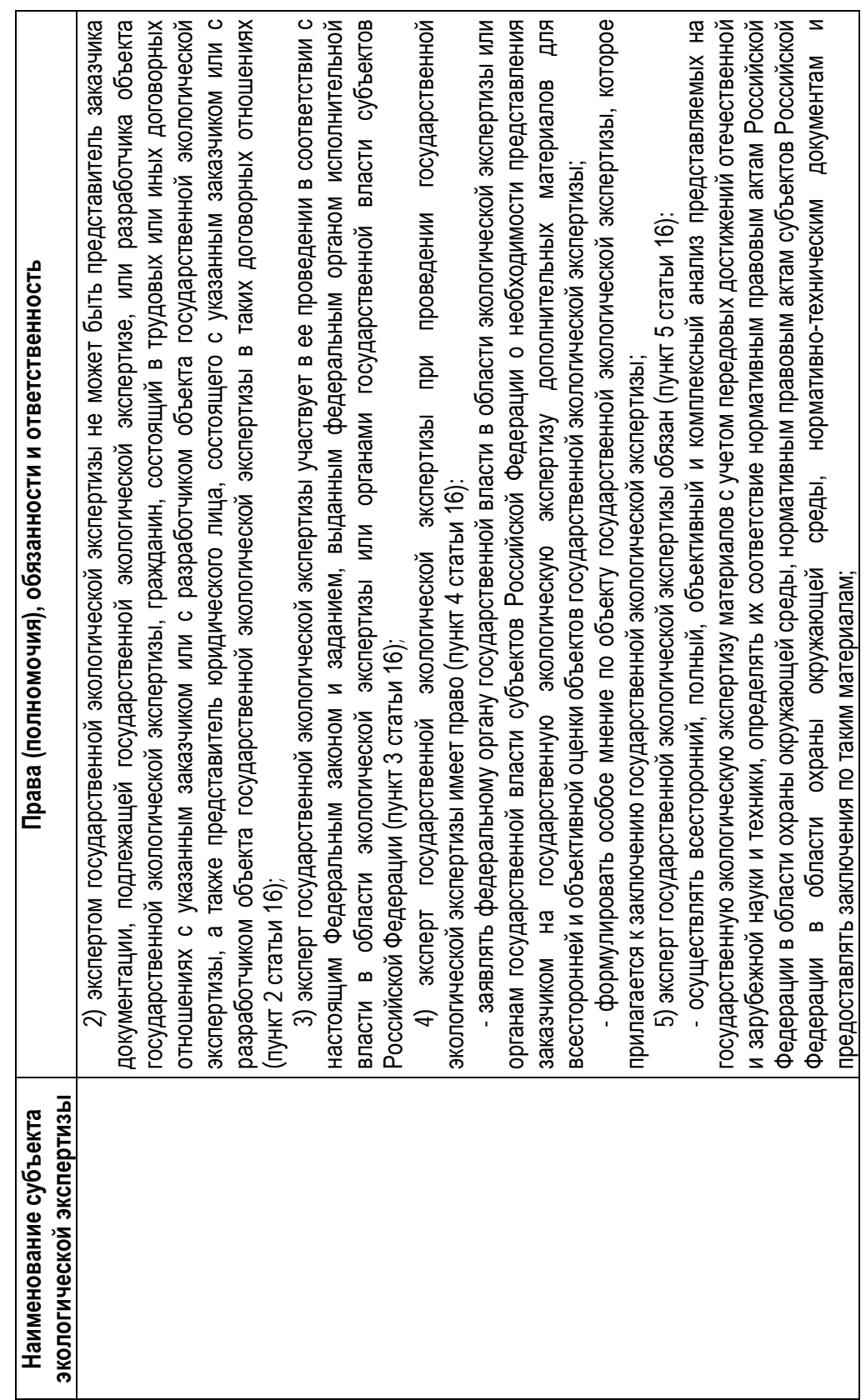




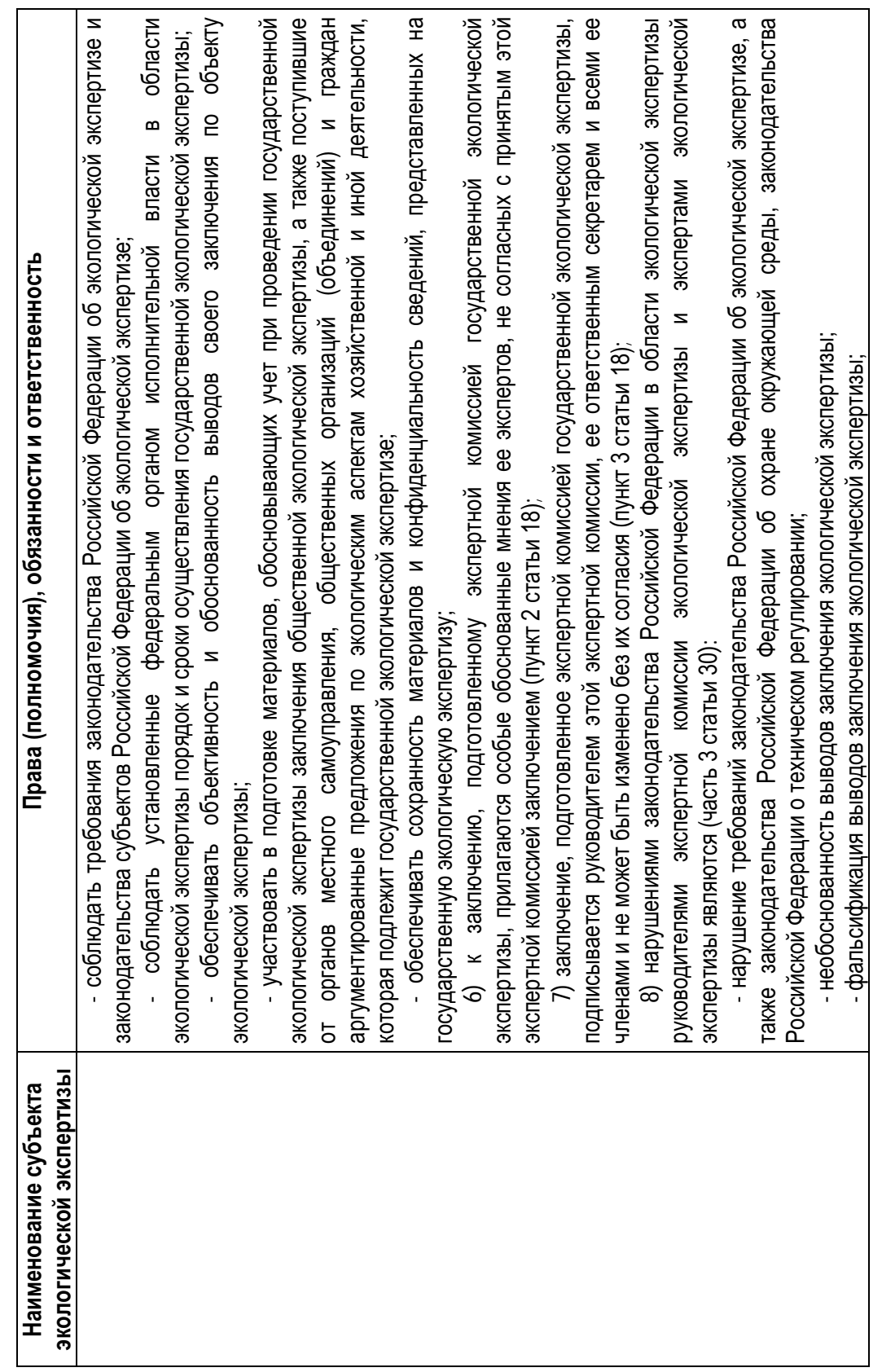




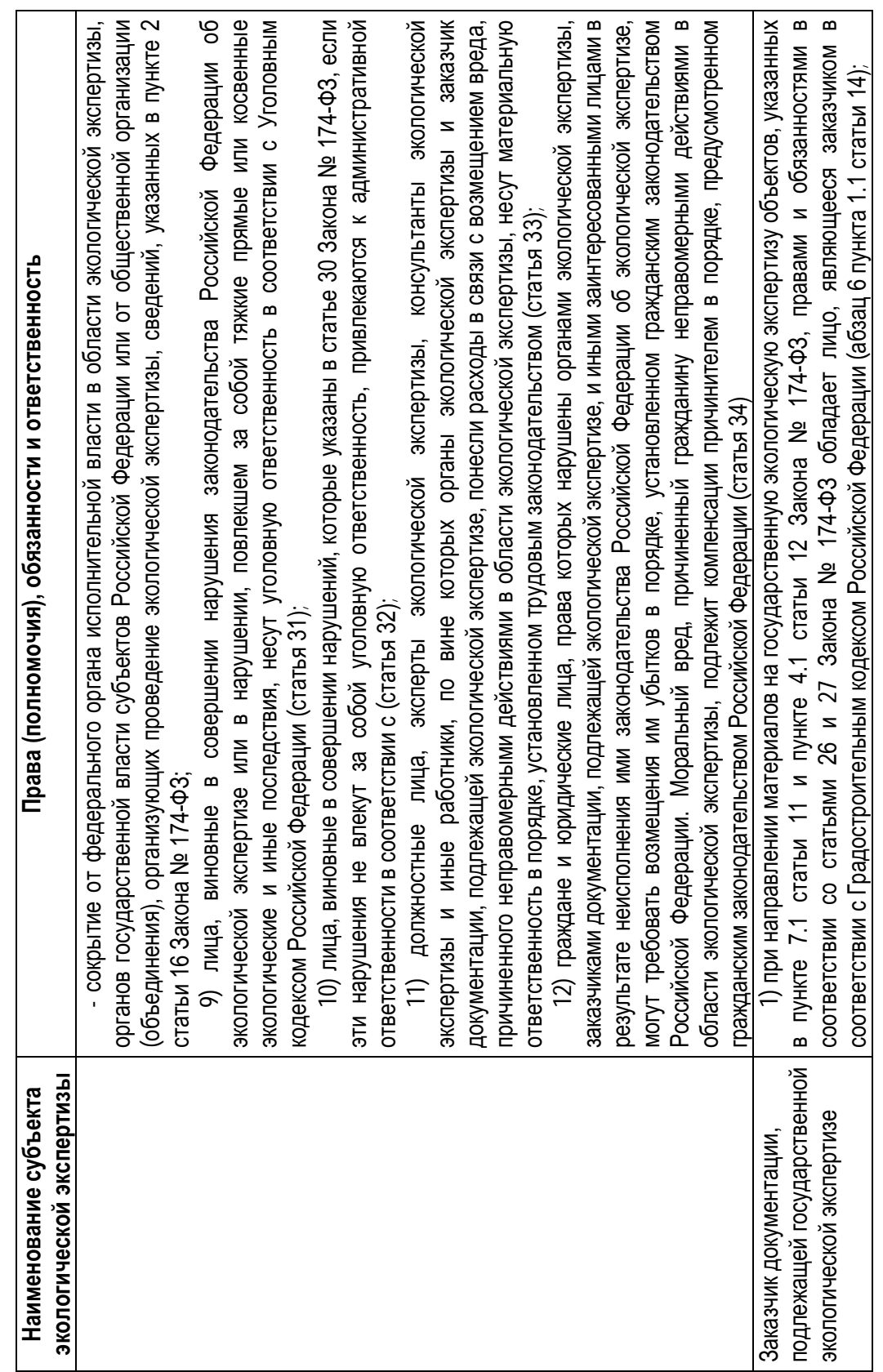




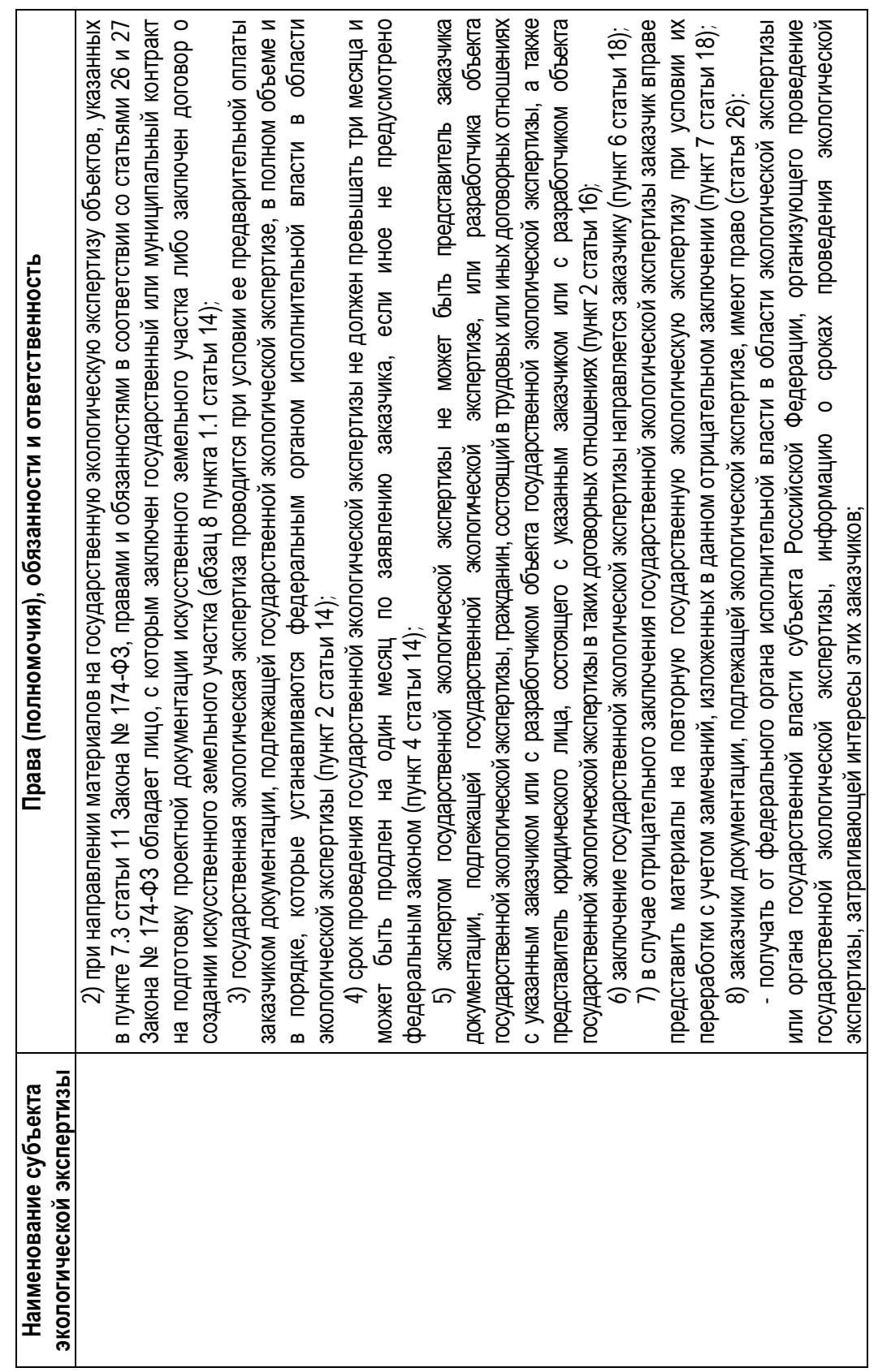




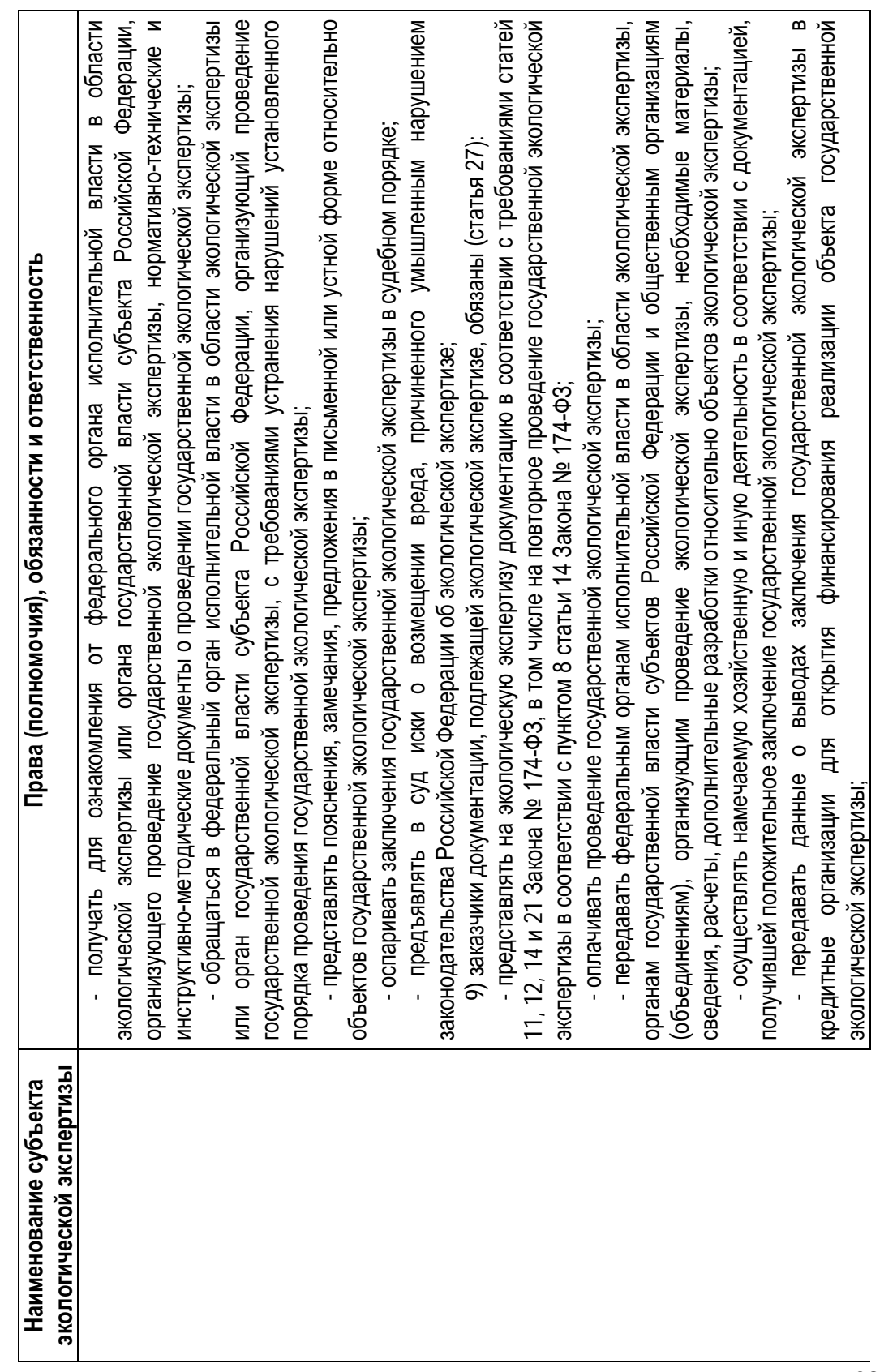




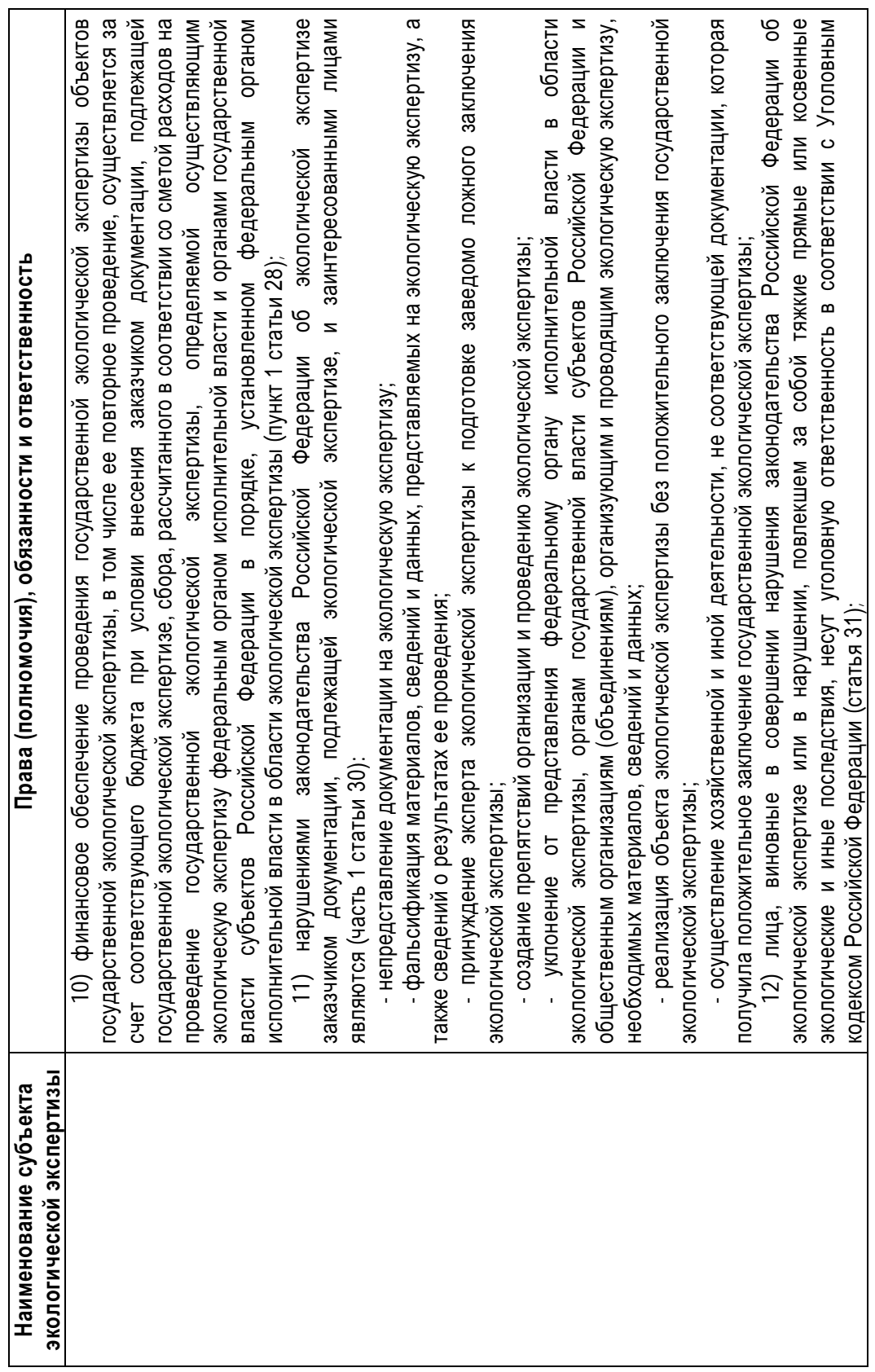




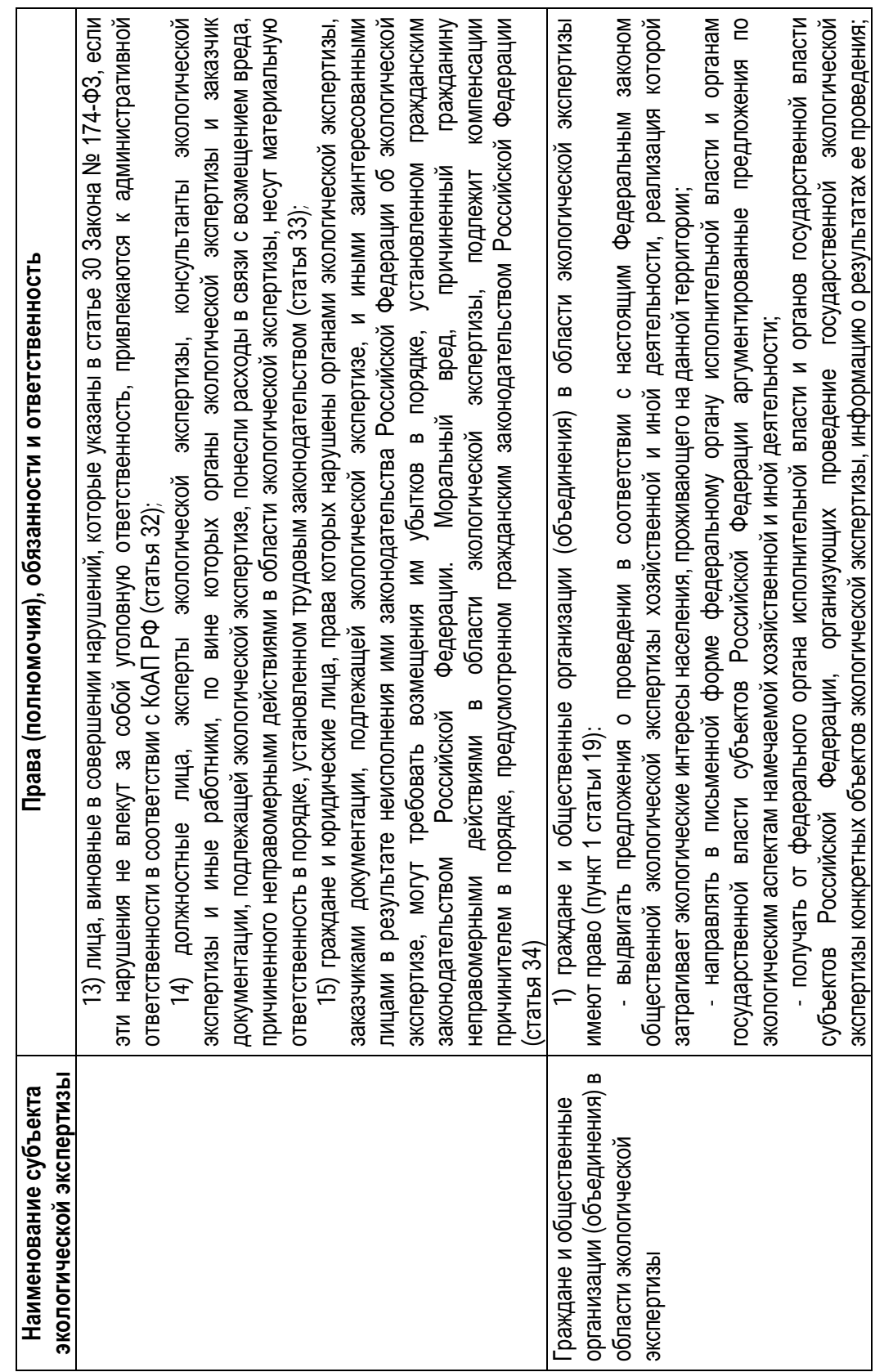




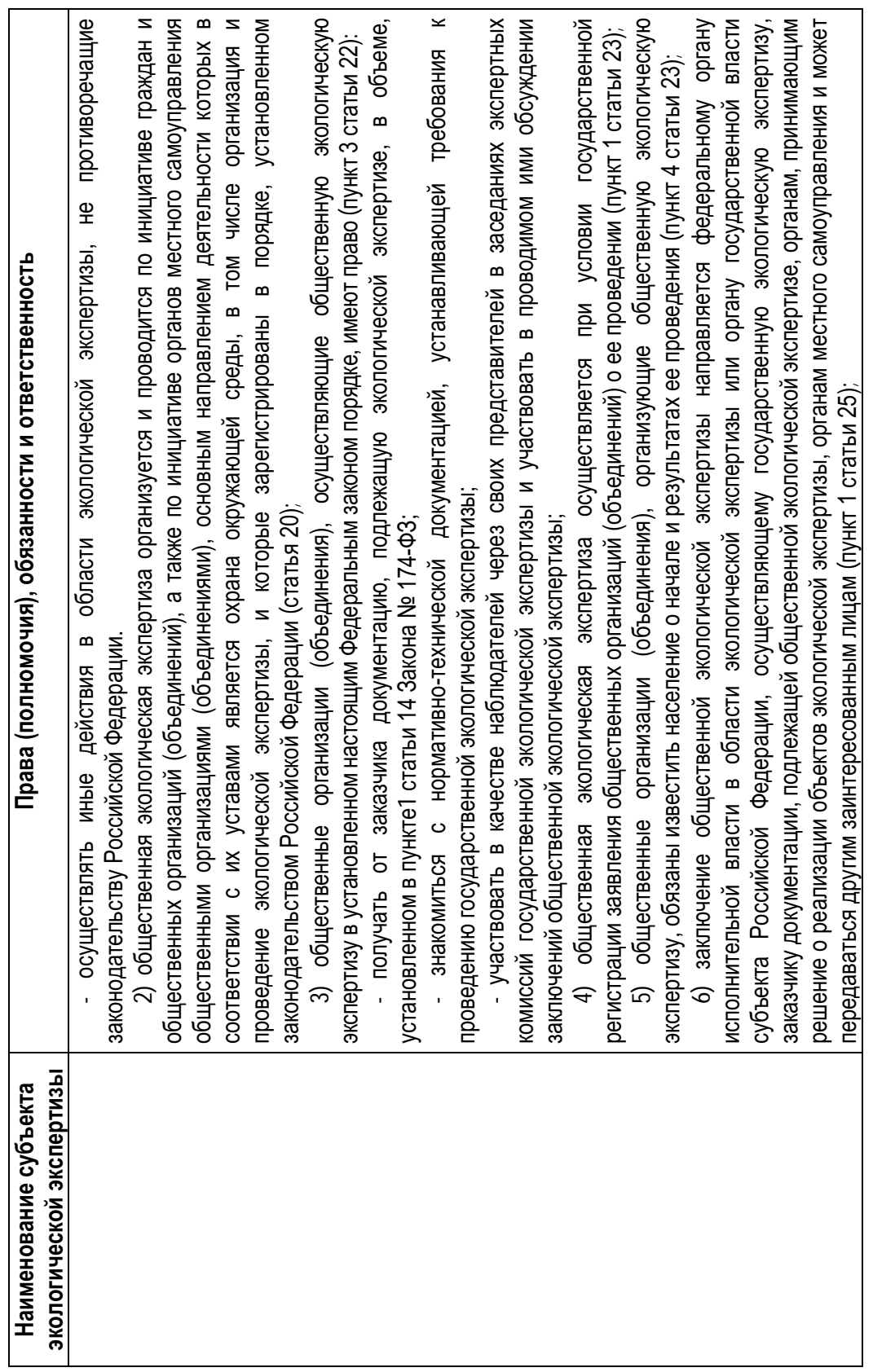




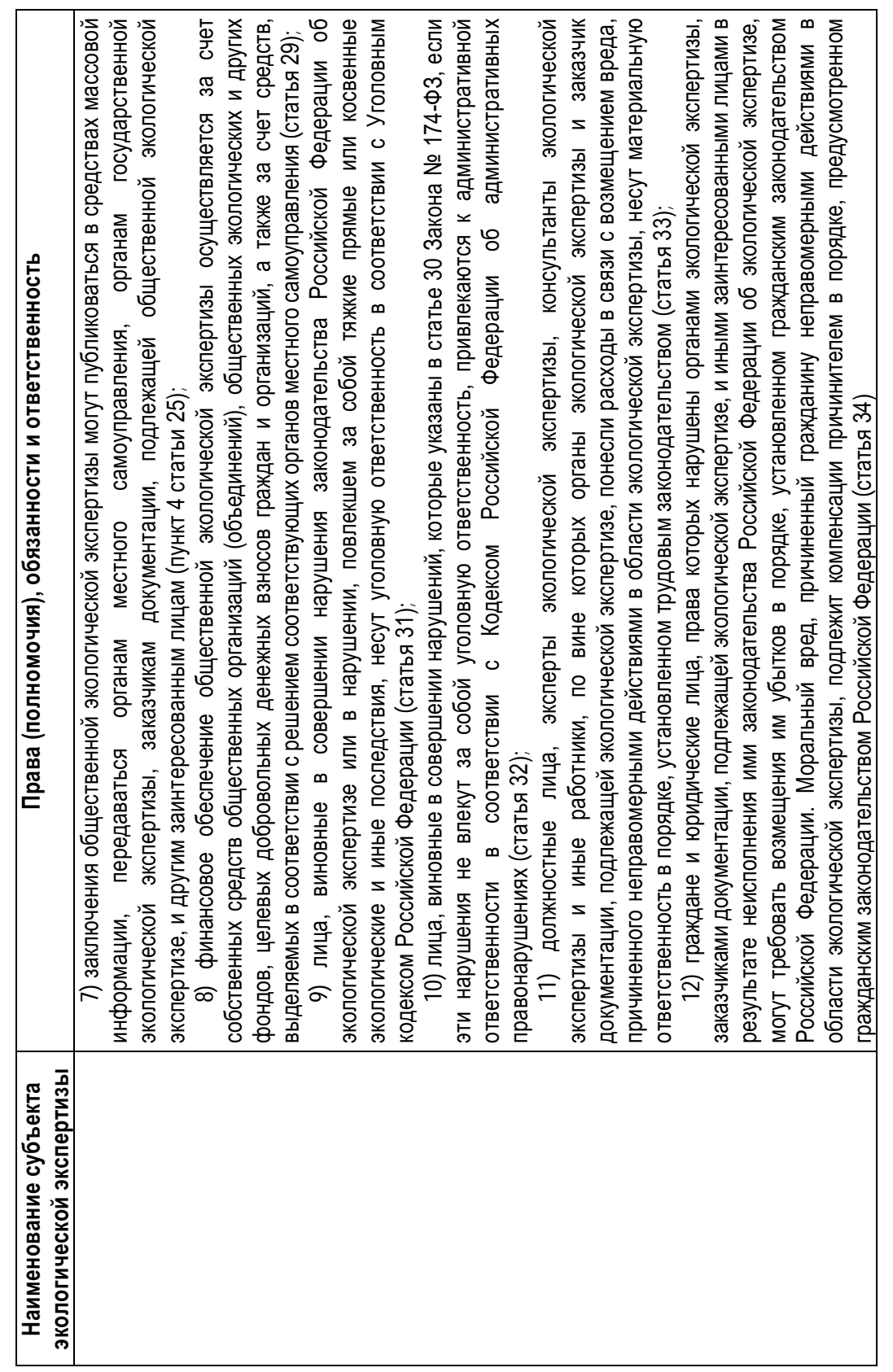




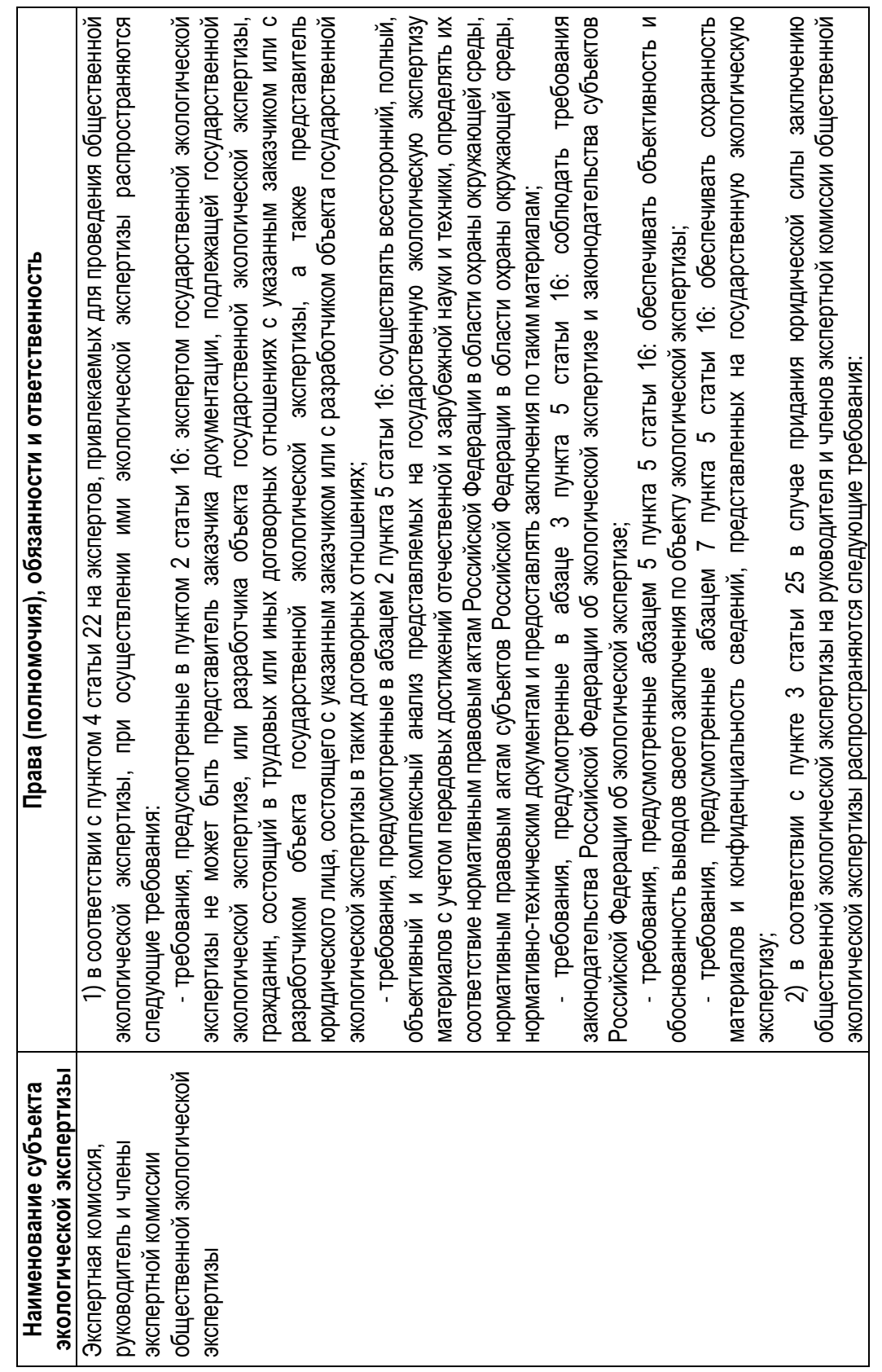




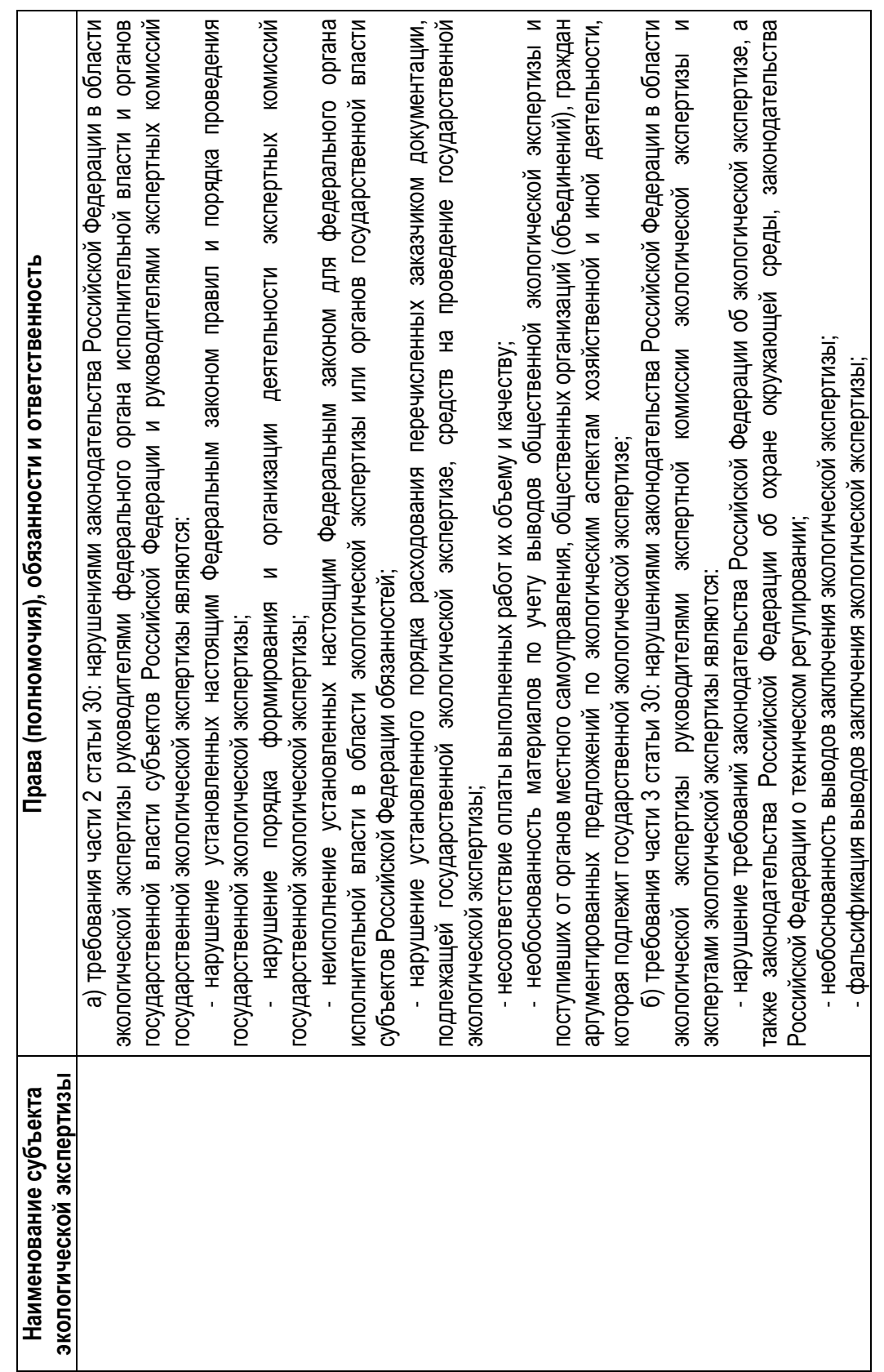




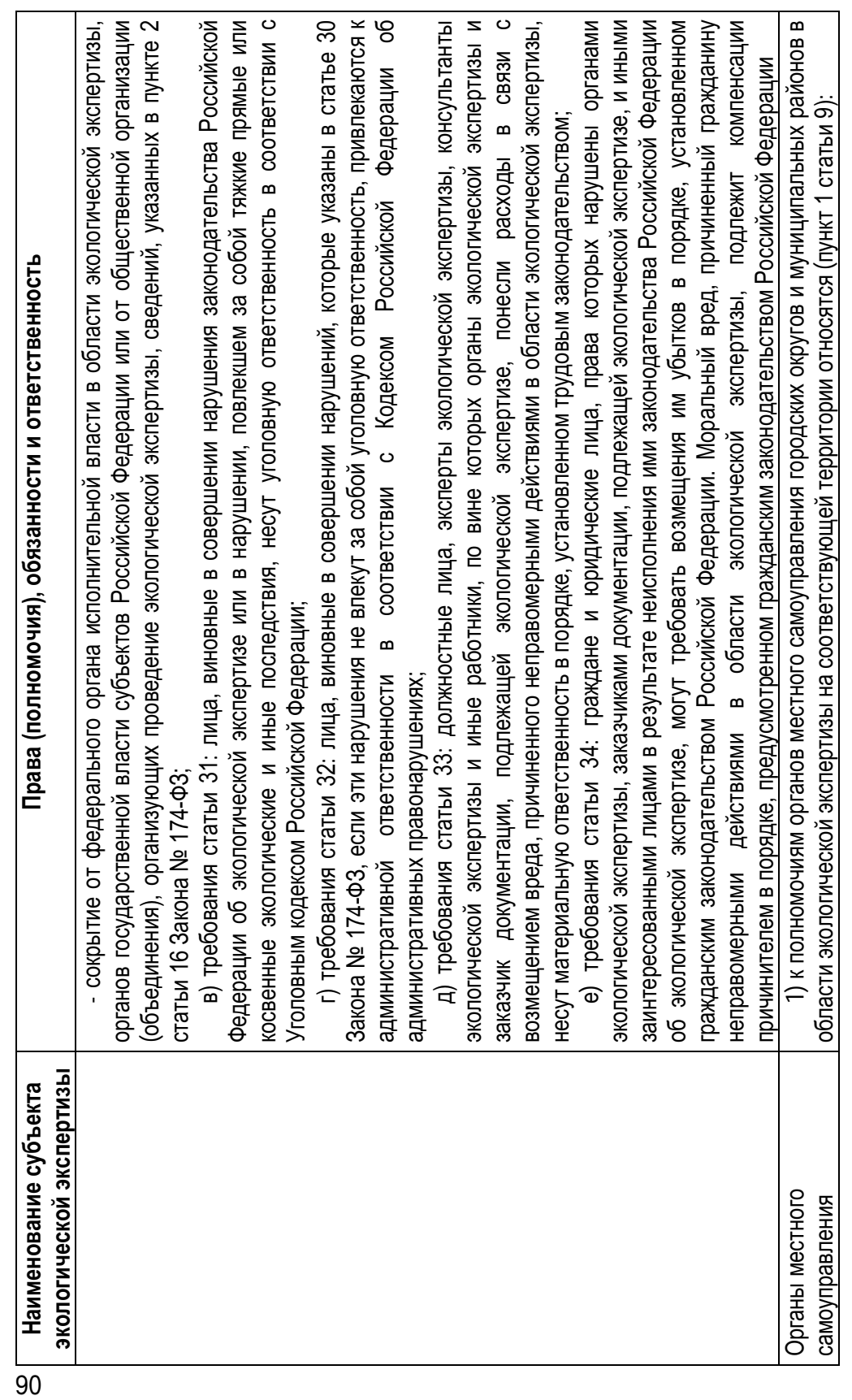




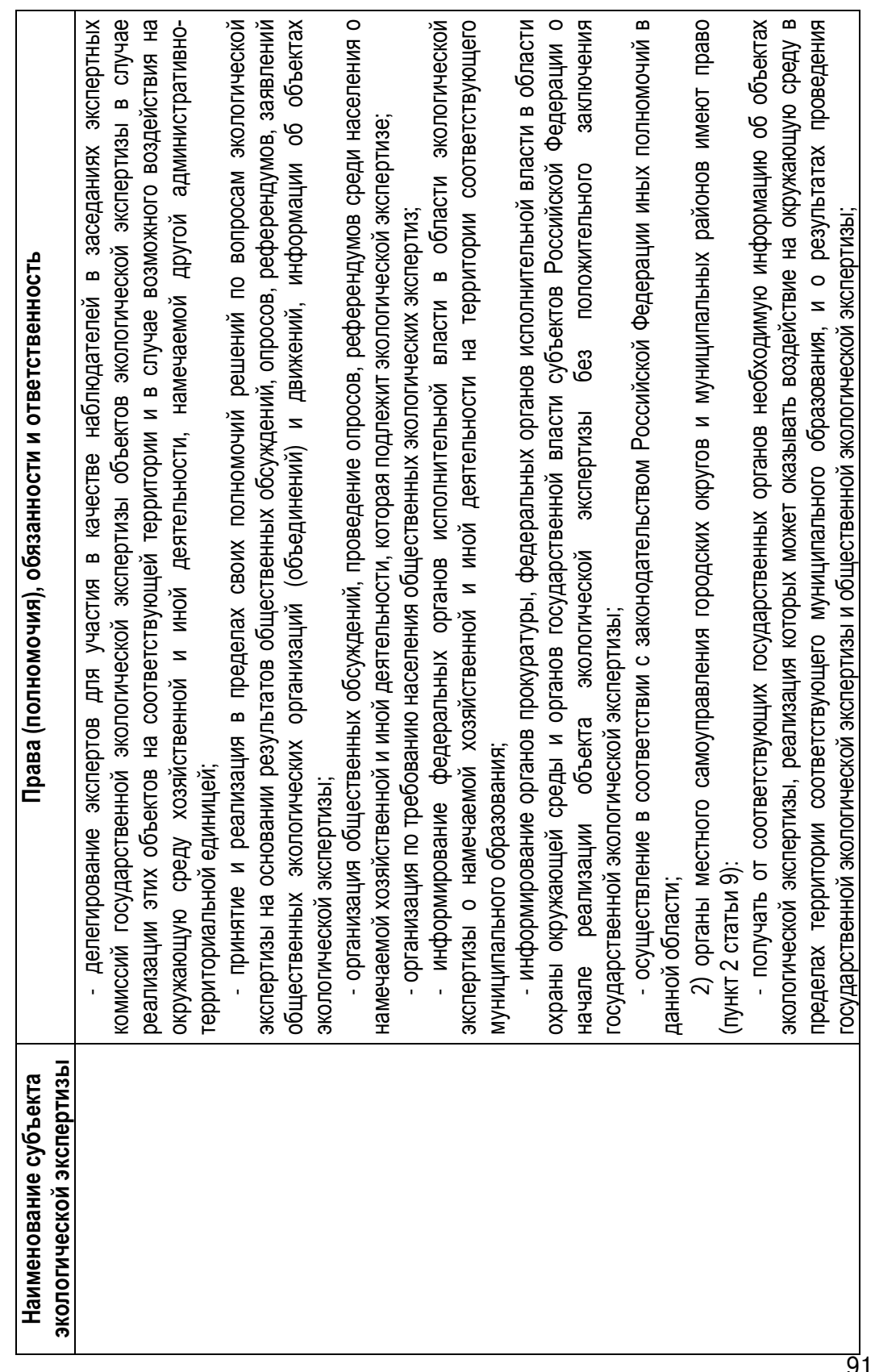




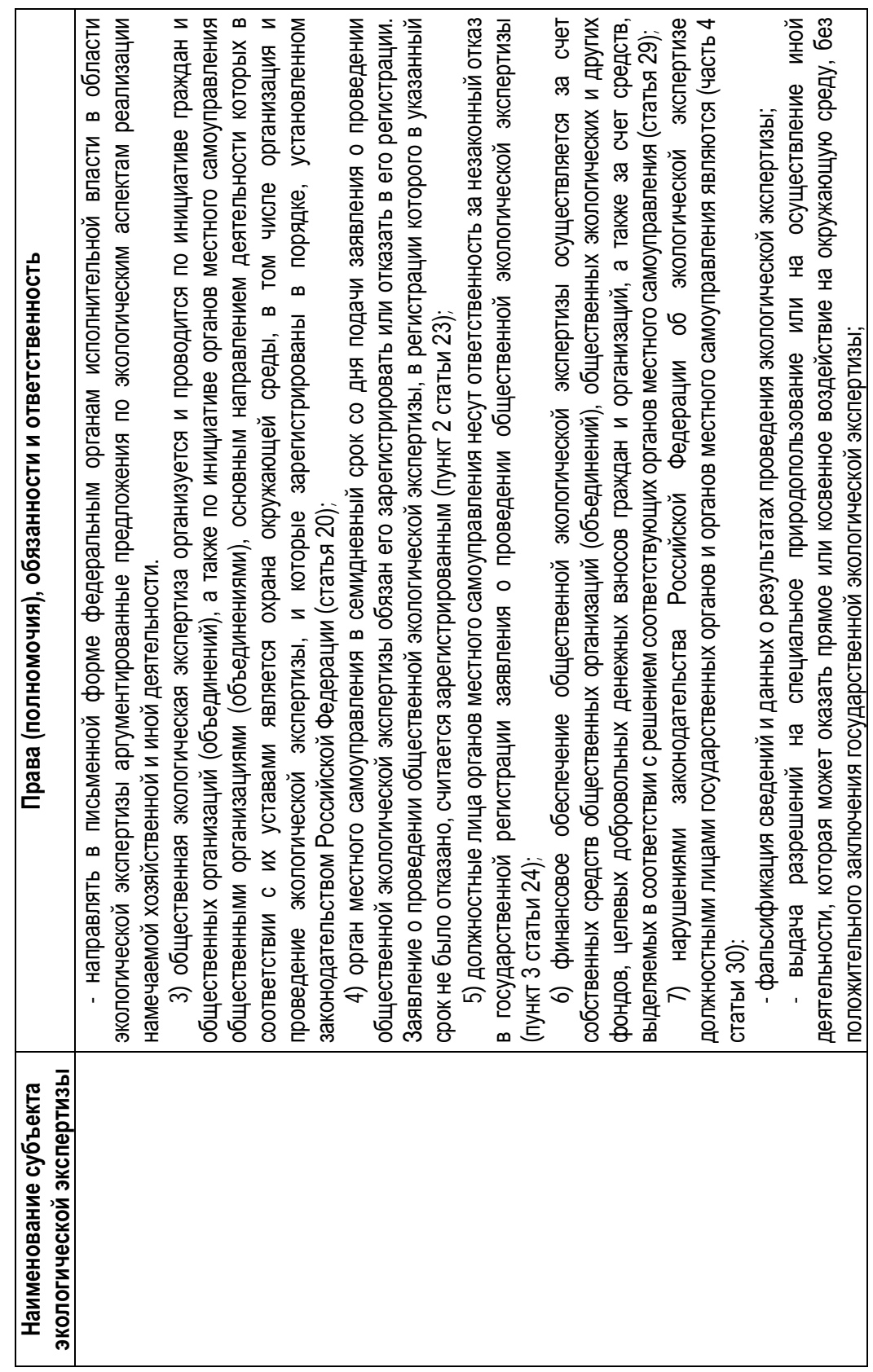




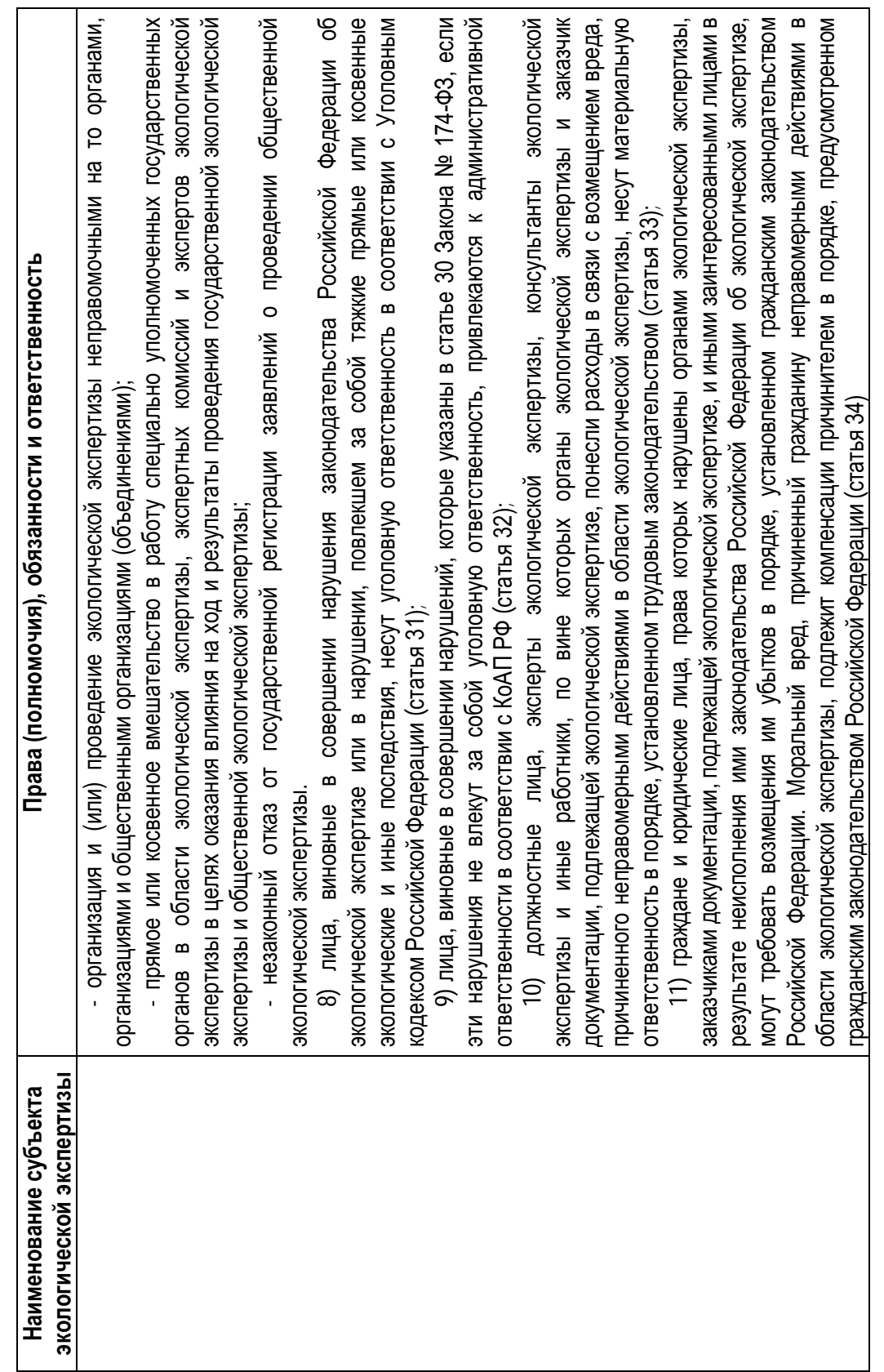




\section{6. Порядок проведения экологической экспертизы}

\subsection{1. Общий порядок}

Порядок проведения государственной экологической экспертизы установлен статьями 14 - 18 Закона № 174-Ф3; постановлением Правительства РФ от 22.09.1993 № 942 «Об утверждении Положения о государственной экологической экспертизе»; Регламентом № 204, а также определяется нормативными правовыми актами субъектов РФ.

Закон № 174-ФЗ предусматривает:

1) общий порядок проведения государственной экологической экспертизы;

2) порядок проведения государственной экологической экспертизы объектов, указанных в пункте 7.1 статьи 11 (проектной документации объектов, строительство, реконструкцию которых предполагается осуществлять на землях особо охраняемых природных территорий федерального значения, на Байкальской природной территории, а также проектной документации особо опасных, технически сложных и уникальных объектов, объектов обороны и безопасности, строительство, реконструкцию которых предполагается осуществлять на землях особо охраняемых природных территорий региональногои местного значения, в случаях, если строительство, реконструкция таких объектов на землях особо охраняемых природных территорий допускаются законодательством Российской Федерации и законодательством субъектов Российской Федерации) и пункте 7.3 статьи 11 (проектной документации искусственных земельных участков, создание которых предполагается осуществлять на водных объектах, находящихся в собственности Российской Федерации) и пункте 4.1 статьи 12 Закона № 174-ФЗ (проектной документации объектов, строительство, реконструкцию которых предполагается осуществлять на землях особо охраняемых природных территорий регионального и местного значения, за исключением проектной документации объектов, указанных в пункте 7.1 статьи 11 Закона № 174-Ф3, в соответствии с законодательством Российской Федерации и законодательством субъектов Российской Федерации);

3) особый порядок проведения государственной экологической экспертизы отдельных объектов экологической экспертизы, установленный иными федеральными законами.

Общий порядок проведения государственной экологической экспертизы предусматривает следующие стадии:

1) представление заказчиком необходимых материалов для проведения государственной экологической экспертизы в уполномоченный орган государственной власти (почтовым отправлением, лично либо в форме электронных документов). 
Для проведения государственной экологической экспертизы объектов, указанных в статье 11 Закона № 174-Ф3, заказчик представляет:

- заявление, содержащее информацию о наименовании объекта государственной экологической экспертизы, подробную опись материалов, представляемых на государственную экологическую экспертизу (1 экз.);

- документацию, подлежащую государственной экологической экспертизе в соответствии со статьей 11 Закона № 174-ФЗ, в объеме, который определен в установленном порядке, и содержащую материалы оценки воздействия на окружающую среду хозяйственной и иной деятельности, которая подлежит государственной экологической экспертизе (2 экз.).

Для проведения государственной экологической экспертизы необходимы также следующие документы:

- положительные заключения и (или) документы согласований органов федерального надзора и контроля и органов местного самоуправления, получаемые в установленном законодательством Российской Федерации порядке;

- заключения федеральных органов исполнительной власти по объекту государственной экологической экспертизы в случае его рассмотрения указанными органами и заключение общественной экологической экспертизы в случае ее проведения;

- материалы обсуждений объекта государственной экологической экспертизы с гражданами и общественными организациями (объединениями), организованных органами местного самоуправления;

- реквизиты, необходимые для подготовки счета на оплату заявителем проведения государственной экологической экспертизы (идентификационный номер налогоплательщика (далее - ИНН), банковский идентификационный код (далее - БИК), код причины постановки на учет (далее - КПП), код общероссийского классификатора предприятий и организаций (далее - ОКПО), расчетный счет, корреспондентский счет (далее - к/счет).

Указанные документы либо заказчик представляет по собственной инициативе, либо уполномоченные органы в области экологической экспертизы сами осуществляют соответствующий запрос в государственные органы и органы местного самоуправления.

От заказчика запрещается требовать представление:

- документов и информации или осуществления действий, предоставление или осуществление которых не предусмотрено нормативными правовыми актами, регулирующими отношения, возникающие в связи с предоставлением государственной услуги;

- документов и информации, которые в соответствии с нормативными правовыми актами Российской Федерации, нормативными правовыми актами субъектов Российской Федерации и муниципальными правовыми актами находятся в распоряжении государственных органов, предоставля- 
ющих государственную услугу, иных государственных органов, органов местного самоуправления и (или) подведомственных государственным органам местного самоуправления организаций, участвующих в предоставлении государственных и муниципальных услуг, за исключением документов, указанных в части 6 статьи 7 Федерального закона от 27.07.2010 № 210ФЗ «Об организации предоставления государственных и муниципальных услуг»;

2) прием и регистрация заявления и материалов - со дня поступления заявления и материалов.

Основанием для отказа в приеме документов, необходимых для предоставления государственной услуги, является признание недействительности усиленной квалифицированной электронной подписи заказчика в порядке, установленном Федеральным законом от 06.04.2011 № 63-Ф3 «Об электронной подписи», выявленное в результате ее проверки (пункт 11 Регламента № 204).

В соответствии с пунктом 21 Регламента № 204 основаниями для отказа в предоставлении государственной услуги являются:

- документация не является объектом государственной экологической экспертизы федерального уровня;

- отсутствие документа, подтверждающего оплату проведения государственной экологической экспертизы, по истечении 30 календарных дней со дня получения заявителем уведомления о необходимости оплаты государственной экологической экспертизы;

- непредставление материалов, необходимых для организации и проведения государственной экологической экспертизы, по истечении срока, установленного в уведомлении о несоответствии ранее представленных материалов установленным требованиям, направленном в соответствии с пунктом 41 Регламента № 204;

- письменный запрос заявителя о возвращении документации, являющейся объектом государственной экологической экспертизы;

3) рассмотрение заявления и представленных материалов - со дня получения ответственным исполнителем зарегистрированных заявления и материалов, включающий в себя осуществление следующих мероприятий: проверки комплектности материалов, являющихся объектом государственной экологической экспертизы; в случае установления некомплектности подготовку уведомления в адрес заявителя о некомплектности материалов заявителя; в случае установления комплектности: подготовку сметы расходов на проведение государственной экологической экспертизы; подготовку уведомления в адрес заявителя о необходимости оплаты проведения государственной экологической экспертизы);

4) оплата заказчиком государственной услуги в соответствии со счетом и сметой расходов на проведение государственной экологической экспер- 
тизы в течение 30 календарных дней со дня получения уведомления о необходимости оплаты проведения государственной экологической экспертизы;

5) формирование и направление межведомственных запросов - в случае непредставления по инициативе заказчика документов, представление которых для него не является обязательным (документов и информации, которые в соответствии с нормативными правовыми актами Российской Федерации, нормативными правовыми актами субъектов Российской Федерации и муниципальными правовыми актами находятся в распоряжении государственных органов, предоставляющих государственную услугу, иных государственных органов, органов местного самоуправления и (или) подведомственных государственным органам местного самоуправления организаций, участвующих в предоставлении государственных и муниципальных услуг, за исключением документов, указанных в части 6 статьи 7 Федерального закона от 27.07.2010 № 210-Ф3 «Об организации предоставления государственных и муниципальных услуг»);

6) подготовка и издание приказа об организации и проведении государственной экологической экспертизы.

Начало срока проведения государственной экологической экспертизы устанавливается не позднее чем через пятнадцать дней, после ее оплаты и приемки комплекта необходимых материалов и документов в полном объеме и в количестве.

Это включает в себя проведение следующих процедур: образование экспертной комиссии государственной экологической экспертизы для проведения экологической экспертизы конкретного объекта - назначение руководителя и ответственного секретаря экспертной комиссии государственной экологической экспертизы, формирование экспертной комиссии государственной экологической экспертизы при участии ее руководителя и утверждение ее персонального состава; утверждение срока проведения экспертизы;

7) проведение государственной экологической экспертизы - со дня утверждения приказа об организации и проведении государственной экологической экспертизы.

Это включает в себя проведение организационного заседания экспертной комиссии; для получения дополнительной информации - подготовку соответствующего уведомления; в случае необходимости - выезд членов экспертной комиссии на место намечаемой хозяйственной и иной деятельности; подготовку экспертных заключений; проведение заседаний экспертной комиссии; подготовку проекта заключения экспертной комиссии.

Срок проведения государственной экологической экспертизы не должен превышать три месяца и может быть продлен на один месяц по заявлению заказчика, если иное не предусмотрено федеральным законом;

8) утверждение заключения государственной экологической экспертизы. 
Заключение, подготовленное экспертной комиссией, в двух экземплярах с особыми мнениями экспертов и протокол заключительного заседания экспертной комиссии передаются в уполномоченное подразделение Росприроднадзора (территориального органа Росприроднадзора) для подготовки проекта приказа об утверждении заключения).

Заключение, подготовленное экспертной комиссией государственной экологической экспертизы, после его утверждения федеральным органом исполнительной власти в области экологической экспертизы или органами государственной власти субъектов Российской Федерации приобретает статус заключения государственной экологической экспертизы;

9) выдача заключения государственной экологической экспертизы - со дня утверждения приказом экспертного заключения, включает в себя: направление уведомления о завершении государственной экологической экспертизы и направление государственной экологической экспертизы заказчику; для осуществления соответствующих контрольных функций информация о заключении государственной экологической экспертизы направляется территориальным органам федерального органа исполнительной власти, осуществляющего федеральный государственный экологический надзор (в случае проведения государственной экологической экспертизы федеральным органом исполнительной власти в области экологической экспертизы), органам исполнительной власти субъектов Российской Федерации и органам местного самоуправления и в случаях, определяемых федеральным органом исполнительной власти в области экологической экспертизы, - кредитным организациям, которые осуществляют финансирование реализации объекта государственной экологической экспертизы.

Повторное проведение государственной экологической экспертизы

В соответствии с пунктом 8 статьи 14 Закона № 174-ФЗ повторное проведение государственной экологической экспертизы осуществляется на основании решения суда или арбитражного суда.

Согласно пункта 7 статьи 18 Закона № 174-ФЗ в случае отрицательного заключения государственной экологической экспертизы заказчик вправе представить материалы на повторную государственную экологическую экспертизу при условии их переработки с учетом замечаний, изложенных в данном отрицательном заключении.

В силу требований статьи 27 Закона № 174-ФЗ заказчики документации, подлежащей экологической экспертизе, обязаны представлять на экологическую экспертизу документацию в соответствии с требованиями статей 11, 12, 14 и 21 Закона № 174-Ф3, в том числе на повторное проведение государственной экологической экспертизы в соответствии с пунктом 8 статьи 14 Закона № 174-ФЗ. 


\subsection{2. Особенности порядка проведения государственной экологической экспертизы объектов, указанных в пунктах 7.1 и 7.3 статьи 11; пункте 4.1 статьи 12 Закона № 174-Ф3}

Направление материалов на проведение государственной экологической экспертизы указанных объектов осуществляется федеральным органом исполнительной власти, органом исполнительной власти субъекта Российской Федерации, уполномоченными на проведение государственной экспертизы проектной документации, в течение трех дней с даты представления этих материалов в данные органы.

Законодательством РФ предусматривается иной пакет документов для подачи заявления о проведении государственной экологической экспертизы.

Для проведения государственной экологической экспертизы, в том числе повторной, объектов, указанных в пунктах 7.1 и 7.3 статьи 11 Закона № 174-Ф3, заявитель представляет:

а) заявление, содержащее информацию о наименовании объекта государственной экологической экспертизы, подробную опись материалов, представляемых на государственную экологическую экспертизу;

б) документацию, подлежащую государственной экологической экспертизе и содержащую материалы оценки воздействия объектов, строительство, реконструкцию которых предполагается осуществлять на землях особо охраняемых природных территорий, на соответствующую особо охраняемую природную территорию, в случае проведения государственной экологической экспертизы объектов, указанных в пункте 7.1 статьи 11 Закона № 174-Ф3;

в) документацию, подлежащую государственной экологической экспертизе и содержащую материалы оценки воздействия искусственных земельных участков на окружающую среду, в случае проведения государственной экологической экспертизы объектов, указанных в пункте 7.3 статьи 11 Закона № 174-Ф3.

Кроме того, для проведения государственной экологической экспертизы, в том числе повторной, объектов, указанных в пунктах 7.1 и 7.3 статьи 11 Закона № 174-Ф3, необходимы следующие документы:

а) заключение общественной экологической экспертизы в случае ее проведения;

б) материалы обсуждений объекта государственной экологической экспертизы с гражданами и общественными организациями (объединениями), организованных органами местного самоуправления;

в) реквизиты, необходимые для подготовки счета на оплату заявителем проведения государственной экологической экспертизы (ИНН, БИК, КПП, ОКПО, расчетный счет, к/счет).

Указанные документы либо заказчик представляет по собственной инициативе, либо уполномоченные органы в области экологической эксперти- 


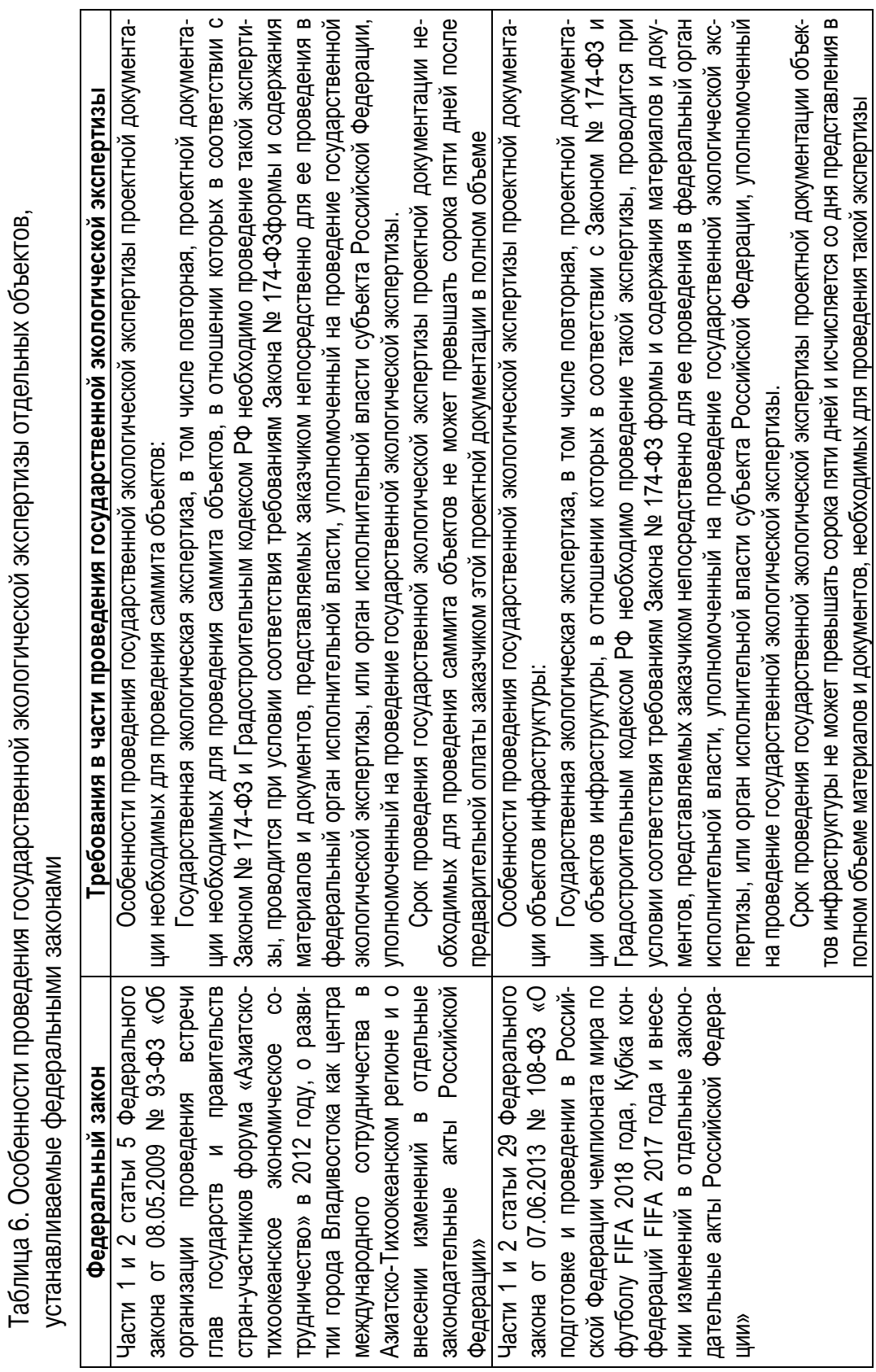

100 


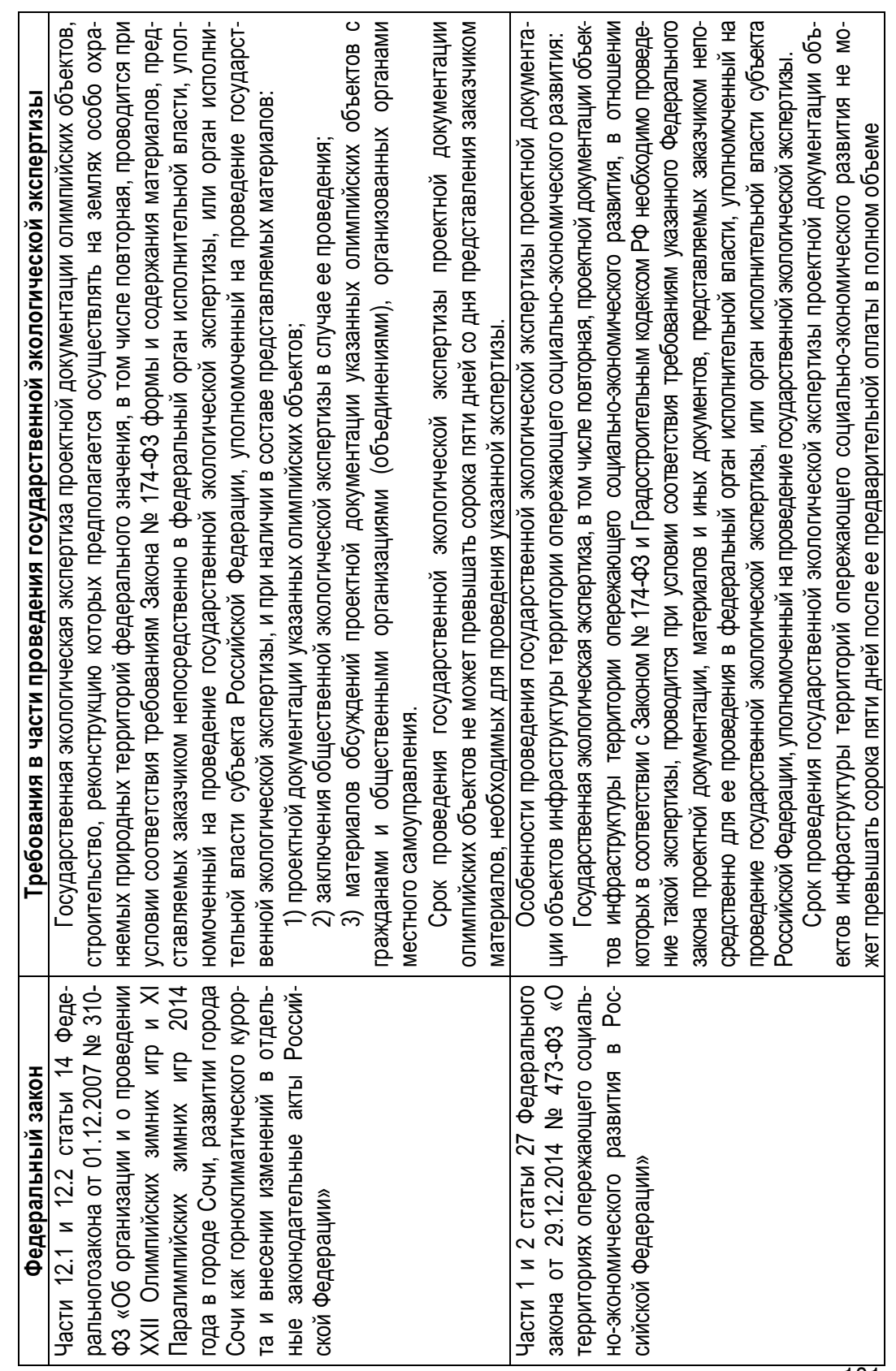


зы сами осуществляют соответствующий запрос в государственные органы и органы местного самоуправления (в случае, если заказчик не представил их сам).

Законодательством РФ предусмотрен иной срок издания приказа об организации и проведении государственной экологической экспертизы не должен превышать 3 рабочих дней после ее оплаты и приемки комплекта необходимых материалов заявителя в полном объеме и в количестве.

Особенности проведения государственной экологической экспертизы отдельных объектов, устанавливаемые иными федеральными законами, определяются в приведенной таблице (стр. 101-102).

Согласно статье 30 Закона № 174-Ф3 нарушением законодательства РФ об экологической экспертизе заказчиком документации и заинтересованными лицами, является реализация объекта экологической экспертизы без положительного заключения государственной экологической экспертизы.

\subsection{3. Порядок проведения общественной экологической экспертизы}

Действующее законодательство Российской Федерации не определяет порядок проведения общественной экологической экспертизы и не устанавливает соответствующих процедур.

Вместе с тем общие требования и условия проведения общественной экологической экспертизы определяются в статьях 19 - 25 Закона № 174-Ф3.

Анализ указанных норм позволяет выделить следующие основные условия проведения общественной экологической экспертизы:

1) общественная экологическая экспертиза проводится до проведения государственной экологической экспертизы или одновременно с ней;

2) общественная экологическая экспертиза может проводиться независимо от проведения государственной экологической экспертизы тех же объектов экологической экспертизы;

3) общественная экологическая экспертиза осуществляется при условии государственной регистрации заявления общественных организаций (объединений) о ее проведении. При наличии заявлений о проведении общественной экологической экспертизы одного объекта экологической экспертизы от двух и более общественных организаций (объединений) допускается создание единой экспертной комиссии.

Процедуру проведения общественной экологической экспертизы можно представить следующим образом: 
1) подача общественной организацией (объединением) в орган местного самоуправления заявления о проведении общественной экологической экспертизы. В заявлении общественных организаций (объединений) о проведении общественной экологической экспертизы должны быть приведены наименование, юридический адрес и адрес (место нахождения), характер предусмотренной уставом деятельности, сведения о составе экспертной комиссии общественной экологической экспертизы, сведения об объекте общественной экологической экспертизы, сроки проведения общественной экологической экспертизы (См. Приложение № 1);

2) рассмотрение заявления органом местного самоуправления и принятие соответствующего решения о его регистрации. Орган местного самоуправления в семидневный срок со дня подачи заявления о проведении общественной экологической экспертизы обязан его зарегистрировать или отказать в его регистрации. Заявление о проведении общественной экологической экспертизы, в регистрации которого в указанный срок не было отказано, считается зарегистрированным.

В государственной регистрации заявления о проведении общественной экологической экспертизы может быть отказано в случае, если:

общественная экологическая экспертиза ранее была дважды проведена в отношении объекта общественной экологической экспертизы;

заявление о проведении общественной экологической экспертизы было подано в отношении объекта, сведения о котором составляют государственную, коммерческую или иную охраняемую законом тайну;

общественная организация (объединение) не зарегистрирована в порядке, установленном законодательством Российской Федерации, на день обращения за государственной регистрацией заявления о проведении общественной экологической экспертизы;

устав общественной организации (объединения), организующей и проводящей общественную экологическую экспертизу, не соответствует требованиям статьи 20 Закона № 174-Ф3;

требования к содержанию заявления о проведении общественной экологической экспертизы, предусмотренные статьей 23 Закона № 174-ФЗ, не выполнены.

Перечень указанных оснований для отказа в государственной регистрации заявления о проведении общественной экологической экспертизы является исчерпывающим.

При этом должностные лица органов местного самоуправления несут ответственность за незаконный отказ в государственной регистрации заявления о проведении общественной экологической экспертизы;

3) организация и проведение общественной организацией (объединением) общественной экологической экспертизы. Общественные организации (объединения), организующие общественную экологическую экспер- 
тизу, обязаны известить население о начале (См.: Приложение № 2)и результатах ее проведения (См.: Приложение № 3);

4) подготовка заключения общественной экологической экспертизы;

5) утверждение заключения общественной экологической экспертизы федеральным органом исполнительной власти в области экологической экспертизы или органом государственной власти субъекта Российской Федерации.

Заключение общественной экологической экспертизы приобретает юридическую силу после утверждения его федеральным органом исполнительной власти в области экологической экспертизы или органом государственной власти субъекта Российской Федерации;

6) направление заключения общественной экологической экспертизы федеральному органу исполнительной власти в области экологической экспертизы или органу государственной власти субъекта Российской Федерации, осуществляющему государственную экологическую экспертизу, заказчику документации, подлежащей общественной экологической экспертизе, органам, принимающим решение о реализации объектов экологической экспертизы, органам местного самоуправления и может передаваться другим заинтересованным лицам.

\section{7. Результаты проведения экологической экспертизы}

\subsection{1. Результаты экспертизы, проведенной в обычном порядке}

Результатом проведения государственной экологической экспертизы является заключение государственной экологической экспертизы.

Заключением государственной экологической экспертизы является документ, подготовленный экспертной комиссией государственной экологической экспертизы, содержащий обоснованные выводы о соответствии документов и (или) документации, обосновывающих намечаемую в связи с реализацией объекта экологической экспертизы хозяйственную и иную деятельность, экологическим требованиям, установленным техническими регламентами и законодательством в области охраны окружающей среды, одобренный квалифицированным большинством списочного состава указанной экспертной комиссии и соответствующий заданию на проведение экологической экспертизы, выдаваемому федеральным органом исполнительной власти в области экологической экспертизы или органами государственной власти субъектов Российской Федерации.

Если комиссия не пришла к единому мнению, то к заключению, подготовленному экспертной комиссией государственной экологической экспертизы, прилагаются особые обоснованные мнения ее экспертов, не согласных с принятым этой экспертной комиссией заключением. 
Заключение, подготовленное экспертной комиссией государственной экологической экспертизы, подписывается руководителем этой экспертной комиссии, ее ответственным секретарем и всеми ее членами и не может быть изменено без их согласия.

Заключение, подготовленное экспертной комиссией государственной экологической экспертизы, после его утверждения федеральным органом исполнительной власти в области экологической экспертизы или органами государственной власти субъектов Российской Федерации приобретает статус заключения государственной экологической экспертизы.

Утверждение заключения, подготовленного экспертной комиссией государственной экологической экспертизы, является актом, подтверждающим соответствие порядка проведения государственной экологической экспертизы требованиям настоящего Федерального закона и иных нормативных правовых актов Российской Федерации.

Заключение государственной экологической экспертизы по объектам, указанным в статьях 11 и 12 Закона № 174-Ф3, за исключением проектов нормативных правовых актов Российской Федерации, может быть положительным или отрицательным.

Положительное заключение, подготовленное экспертной комиссией, должно содержать выводы:

- о соответствии документов и (или) документации, обосновывающих намечаемую в связи с реализацией объекта экологической экспертизы хозяйственную и иную деятельность, экологическим требованиям, установленным техническими регламентами и законодательством в области охраны окружающей среды;

- о возможности реализации объекта экспертизы.

Отрицательное заключение, подготовленное экспертной комиссией, может содержать выводы двух видов:

- о необходимости доработки представленных материалов по замечаниям и предложениям, изложенным в заключении, подготовленном экспертной комиссией;

- о недопустимости реализации объекта экспертизы ввиду необеспеченности соблюдения требований экологической безопасности намечаемой деятельности.

Законодательство об экологической экспертизе содержит специальные требования к содержанию заключения государственной экологической экспертизы на проекты нормативных правовых актов Российской Федерации.

В соответствии с абзацем 1 пункта 5 статьи 18Закона № 174-ФЗ заключение государственной экологической экспертизы по объектам, указанным в статьях 11 и 12 Закона № 174-ФЗ, за исключением проектов нормативных правовых актов Российской Федерации, может быть положительным или отрицательным. 
На проекты нормативных правовых актов Российской Федерации заключение государственной экологической экспертизы не должно быть положительным или отрицательным. Такое заключение должно содержать:

- выводы о соответствии (несоответствии) основных положений указанного проекта правового акта законодательству Российской Федерации в области охраны окружающей природной среды и требованиям экологической безопасности;

- выводы об экологических и связанных с ними иных последствиях реализации данного объекта экспертизы.

Положительное заключение государственной экологической экспертизы является одним из обязательных условий финансирования и реализации объекта государственной экологической экспертизы. Положительное заключение государственной экологической экспертизы имеет юридическую силу в течение срока, определенного федеральным органом исполнительной власти в области экологической экспертизы или органами государственной власти субъектов Российской Федерации, проводящим конкретную государственную экологическую экспертизу.

Положительное заключение государственной экологической экспертизы теряет юридическую силу в случае:

- доработки объекта государственной экологической экспертизы по замечаниям проведенной ранее государственной экологической экспертизы;

- изменения условий природопользования федеральным органом исполнительной власти в области охраны окружающей среды;

- реализации объекта государственной экологической экспертизы с отступлениями от документации, получившей положительное заключение государственной экологической экспертизы, и (или) в случае внесения изменений в указанную документацию;

- истечения срока действия положительного заключения государственной экологической экспертизы;

- внесения изменений в проектную и иную документацию после получения положительного заключения государственной экологической экспертизы.

Правовым последствием отрицательного заключения государственной экологической экспертизы является запрет реализации объекта государственной экологической экспертизы.

Несоблюдение требования обязательного проведения государственной экологической экспертизы проекта международного договора является основанием для признания его недействительным.

Заключения государственной экологической экспертизы по проектам нормативных правовых актов Российской Федерации рассматриваются принимающими эти акты органами государственной власти. 
Заключение государственной экологической экспертизы направляется заказчику. Для осуществления соответствующих контрольных функций информация о заключении государственной экологической экспертизы направляется территориальным органам федерального органа исполнительной власти, осуществляющего федеральный государственный экологический надзор (в случае проведения государственной экологической экспертизы федеральным органом исполнительной власти в области экологической экспертизы), органам исполнительной власти субъектов Российской Федерации и органам местного самоуправления и в случаях, определяемых федеральным органом исполнительной власти в области экологической экспертизы, - кредитным организациям, которые осуществляют финансирование реализации объекта государственной экологической экспертизы.

В случае отрицательного заключения государственной экологической экспертизы заказчик вправе представить материалы на повторную государственную экологическую экспертизу при условии их переработки с учетом замечаний, изложенных в данном отрицательном заключении.

Заключения государственной экологической экспертизы могут быть оспорены в судебном порядке.

Заключение государственной экологической экспертизы в силу требований нормативных правовых актов может входить в перечень документов, необходимый для получения соответствующего разрешения (лицензии). По мнению автора, данное положение законодательства должно быть императивным, то есть необходимо указать, что заключение государственной экологической экспертизы должно входить в перечень документов, необходимый для получения соответствующего разрешения (лицензии).

\subsection{2. Результаты общественной экологической экспертизы}

Заключение общественной экологической экспертизы направляется федеральному органу исполнительной власти в области экологической экспертизы или органу государственной власти субъекта Российской Федерации, осуществляющему государственную экологическую экспертизу, заказчику документации, подлежащей общественной экологической экспертизе, органам, принимающим решение о реализации объектов экологической экспертизы, органам местного самоуправления и может передаваться другим заинтересованным лицам.

Заключение общественной экологической экспертизы приобретает юридическую силу после утверждения его федеральным органом исполнительной власти в области экологической экспертизы или органом государственной власти субъекта Российской Федерации.

При проведении государственной экологической экспертизы заключение общественной экологической экспертизы учитывается в случае, если 


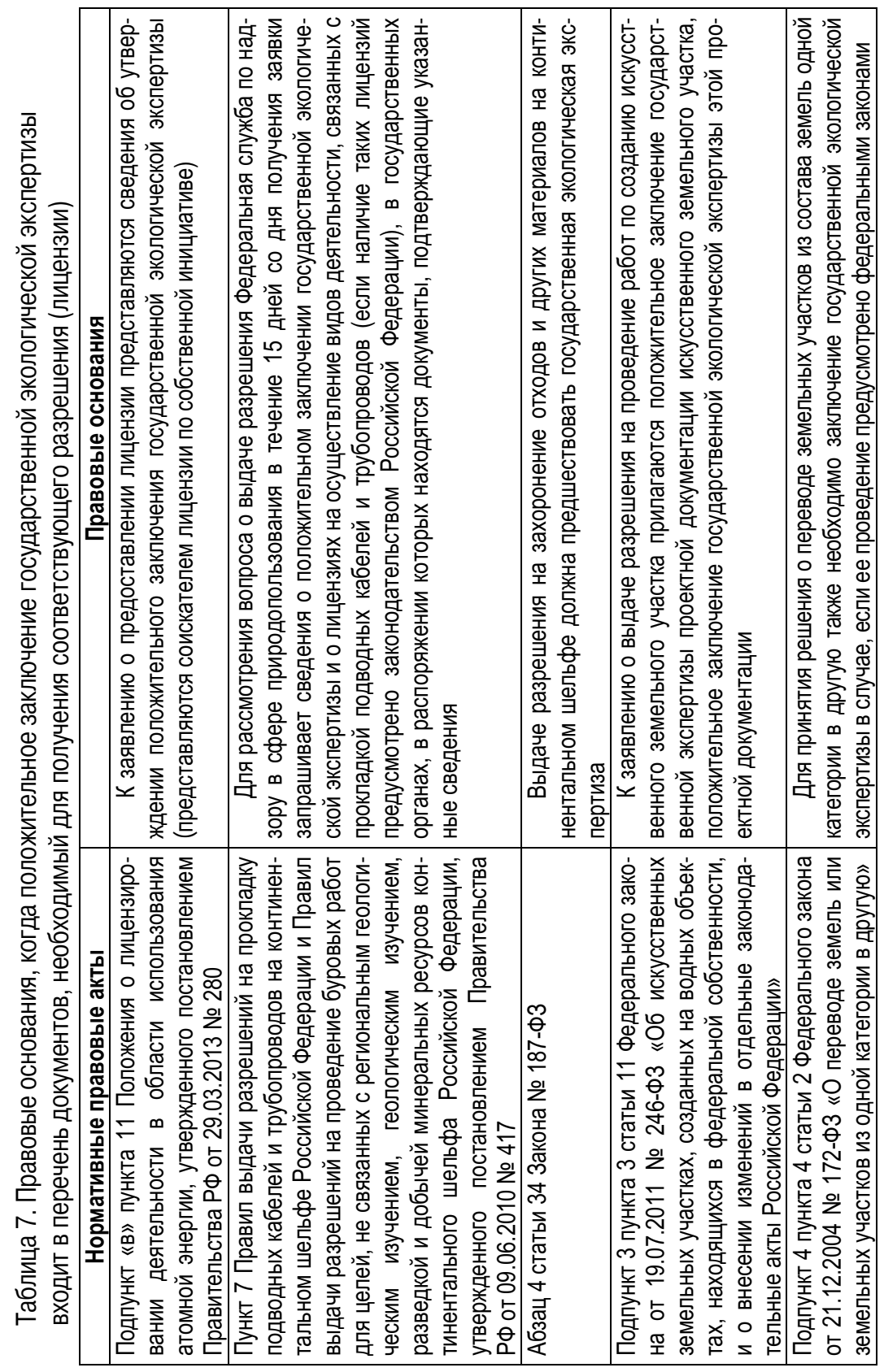




\begin{tabular}{|c|c|c|c|c|}
\hline & 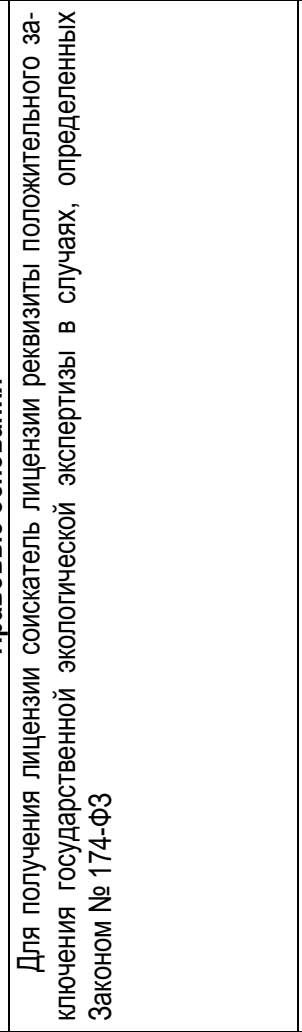 & 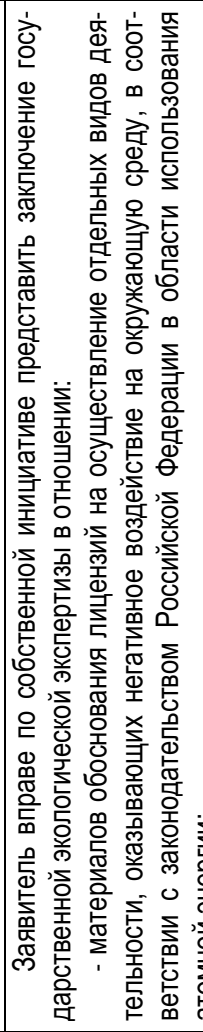 & 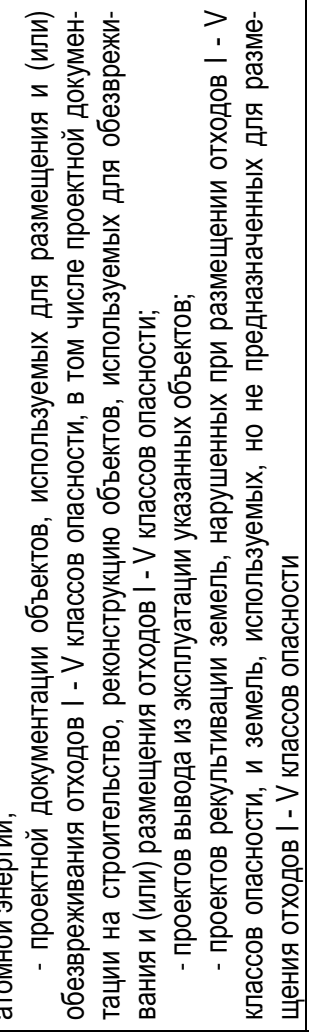 & 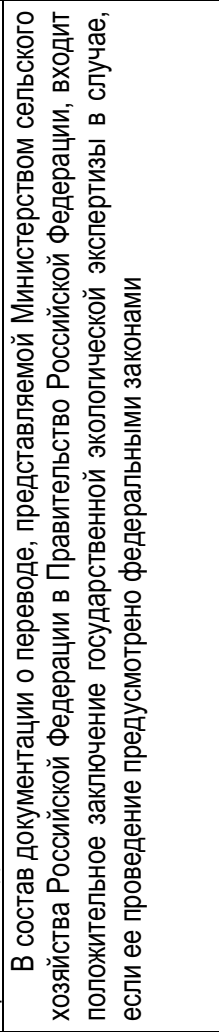 \\
\hline 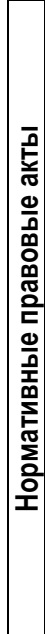 & 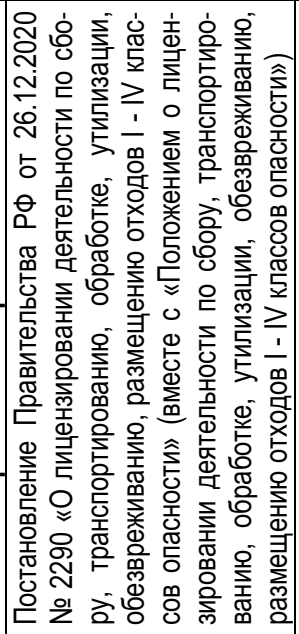 & 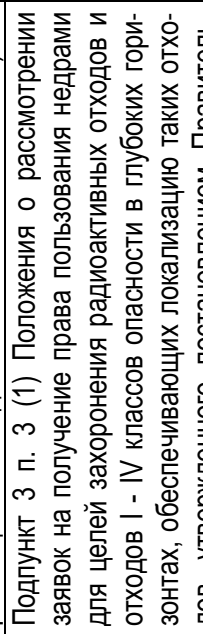 & & 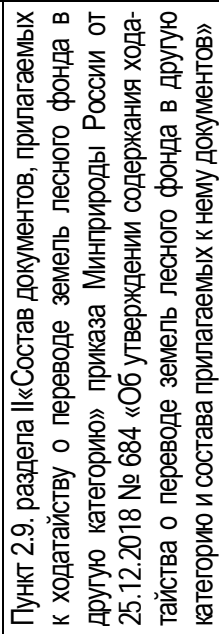 \\
\hline
\end{tabular}


общественная экологическая экспертиза была проведена в отношении того же объекта до дня окончания срока проведения государственной экологической экспертизы.

В случае придания юридической силы заключению общественной экологической экспертизы на руководителя и членов экспертной комиссии общественной экологической экспертизы распространяются требования статьями 30 - 34 Закона № 174-ФЗ.

Заключения общественной экологической экспертизы могут публиковаться в средствах массовой информации, передаваться органам местного самоуправления, органам государственной экологической экспертизы, заказчикам документации, подлежащей общественной экологической экспертизе, и другим заинтересованным лицам.

\section{8. Ответственность за нарушение требований в области экологической экспертизы}

Глава VII Закона № 174-Ф3 регламентирует общие положения ответственности за нарушение законодательства РФ об экологической экспертизе.

В статье 30 Закона № 174-ФЗ в отношении конкретных субъектов в области экологической экспертизы определяются соответствующие виды нарушений.

В соответствии со статьей 31 Закона № 174-ФЗ лица, виновные в совершении нарушения законодательства Российской Федерации об экологической экспертизе или в нарушении, повлекшем за собой тяжкие прямые или косвенные экологические и иные последствия, несут уголовную ответственность в соответствии с Уголовным кодексом РФ.

Согласно статье 32 Закона № 174-ФЗ лица, виновные в совершении нарушений, которые указаны в статье 30 указанного Федерального закона, если эти нарушения не влекут за собой уголовную ответственность, привлекаются к административной ответственности в соответствии с КоАП РФ).

В силу требований статьи 33 Закона № 174-Ф3 должностные лица, эксперты экологической экспертизы, консультанты экологической экспертизы и иные работники, по вине которых органы экологической экспертизы и заказчик документации, подлежащей экологической экспертизе, понесли расходы в связи с возмещением вреда, причиненного неправомерными действиями в области экологической экспертизы, несут материальную ответственность в порядке, установленном трудовым законодательством.

Статья 34 Закона № 174-Ф3 определяет гражданско-правовую ответственность нарушителей. Граждане и юридические лица, права которых нарушены органами экологической экспертизы, заказчиками документации, подлежащей экологической экспертизе, и иными заинтересованными 110 
лицами в результате неисполнения ими законодательства Российской Федерации об экологической экспертизе, могут требовать возмещения им убытков в порядке, установленном гражданским законодательством Российской Федерации. Моральный вред, причиненный гражданину неправомерными действиями в области экологической экспертизы, подлежит компенсации причинителем в порядке, предусмотренном гражданским законодательством Российской Федерации.

Специальный состав правонарушения в области экологической экспертизы предусмотрен только КоАП РФ - статьей 8.4.

Согласно части 1 статьи 8.4 КоАП РФ невыполнение требований законодательства об обязательности проведения государственной экологической экспертизы, финансирование или реализация проектов, программ и иной документации, подлежащих государственной экологической экспертизе и не получивших положительного заключения государственной экологической экспертизы, влечет:

- предупреждение или наложение административного штрафа на граждан;

- на должностных лиц;

- на юридических лиц.

Согласно части 2 статьи 8.4 КоАП РФ осуществление деятельности, не соответствующей документации, которая получила положительное заключение государственной экологической экспертизы, влечет:

- наложение административного штрафа на граждан;

- на должностных лиц;

- на юридических лиц.

Согласно части 3 статьи 8.4 КоАП РФ незаконный отказ в государственной регистрации заявлений о проведении общественной экологической экспертизы влечет наложение административного штрафа на должностных лиц. 


\section{ГЛАВА 2. Экологический аудит}

\section{1. История возникновения}

Необходимость применения экологического аудита впервые возникла в США в 70-х гг. XX в. К этому времени развитие промышленного производства в экономически развитых странах Европы и Северной Америки привело к резкому увеличению мощностей предприятий, что в свою очередь повлекло за собой возрастание количества отходов, загрязняющих окружающую среду. Крупные компании этих стран начали в судебном порядке привлекать к юридической ответственности за нанесение ущерба окружающей среде, что нередко приводило их к значительным финансовым потерям, так как предприятия начали выплачивать крупные суммы по решению судов за причиненный ущерб. Государство стало устанавливать строгие меры ответственности за нарушение экологических норм. И первым шагом на этом пути была оценка бизнесом соответствия осуществляемой ими деятельности нормам законодательства об охране окружающей среды. Такая оценка по определенной аналогии с финансовым аудитом получила название экологического аудита. К середине 90-х годов XX века экологический аудит стал использоваться в виде метода внутреннего административного управления для усиления контроля за деятельностью предприятия.

«Предприятия в США были вынуждены по аналогии с финансовым аудитом, предметом которого являлась проверка соответствия деятельности предприятий налоговому законодательству, прибегнуть к новому инструменту - экологическому аудиту, цель которого заключалась в проведении проверок деятельности предприятий в области охраны окружающей среды и выявления степени соответствия проверяемой деятельности экологическим нормам. Такие проверки позволяли выявить отклонения от нормативов и своевременно принять меры по их устранению и, как следствие, избежать штрафных санкций или продемонстрировать перед государственными органами ответственное поведение и существенно снизить размер штрафа. Экологический аудит получил развитие также в Великобритании, Германии и ряде других стран»8.

В 1984 году Национальным агентством по охране окружающей среды США была разработана концепция экологического аудирования для феде-

${ }^{8}$ Иутин И.Г. Экологический аудит: роль, сущность и проблемы правового регулирования // Государство и право. - 2008. - № 4. - с. 108. 
ральных агентств, на основе которой каждое из федеральных агентств разработало собственную программу экологического аудита. Например, в 1985 году управление по экологическому аудиту и законодательству Министерства энергетики США провело экологическое аудирование своих основных объектов. При этом, например, Национальное управление по аэронавтике и исследованию космического пространства (NASA) привлекало к экологическому аудированию внешних консультантов.

После крупных аварий на химических предприятиях в Великобритании (1974 г.) и Италии (1976 г.) была принята Директива ЕС (1982 г.) об экологическом аудировании.

Экологический аудит получил широкое распространение в Канаде, Великобритании, Швеции, США, Нидерландах и других промышленно развитых странах. Одними из первых компаний, разработавших собственные программы экологического аудита, были US Steel, Allied Chemical и Occidental Petroleum.

Цели, которые ставили национальные правительства при введении экологического аудита, были различными:

Введение экологического аудита во Франции преследовало цели проверки безопасности производства и оказание помощи властям в принятии мер по изучению рисков и обеспечению безопасности.

В Норвегии целью аудита стало усиление экологической деятельности в государственном и частном секторах в дополнение к традиционным инспекционным проверкам промышленных предприятий. Экологический аудит стали проводить при приобретении или передаче недвижимости.

В США экологический аудит начали осуществлять в случаях возникновения конфликтов между предприятием (компанией) - нарушителем и Национальным Агентством по охране окружающей среды при осуществлении экологической программы на предприятии или несоответствия ее экологическому законодательству. Следует отметить, что в этой стране при повторном нарушении экологического законодательства применяется обязательное аудирование.

Специализированный экологический аудит проводится по проблемам оценки опасности производимого продукта, минимизации отходов, вопросам профессиональных заболеваний, промышленной гигиены, контроля загрязнения конкретных природных сред и др. Health, safety and environment audit - аудирование по вопросам здоровья, безопасности и окружающей среды - также получает широкое распространение.

В настоящее время экологический аудит получил широкое практическое применение. В проведении экологического аудита бывают заинтересованы банки, предприятия-природопользователи, новые собственники, государственные органы и общественные организации. Банки ис- 
пользуют экологический аудит с тем, чтобы снизить риск невозврата кредитов, так как произведенная оценка состояния природных ресурсов, природоохранного и технологического оборудования, выявление задолженности по экологическим платежам, произведенным с помощью экологического аудита, позволяют дать более достоверную картину о финансовом состоянии заемщика. Кроме того, западные банки в 2003 году приняли Принципы устойчивости - добровольные принципы, согласно которым одним из условий финансирования проектов, способных оказать воздействие на окружающую среду, является проведение экологического аудита для определения экологических рисков намечаемой деятельности.

Правовое положение экологического аудита также не имеет единого подхода. Например, в ряде стран Европы и США экологический аудит рассматривается преимущественно как внутренний инструмент управления, возможность предоставления информации о его результатах кому-либо в обязательном порядке практически исключена.

Интересный подход по увязке экологического аудита с финансовым аудитом и аудитом соответствия предлагает Международная организация высших органов финансового контроля (Счетных палат) - INTOSAI. Ей выпущен стандарт ISSAI 5120 на эту тему ${ }^{9}$.

Экологический аудит в современных условиях может стать одним из наиболее эффективных правовых институтов, обеспечивающих функционирование механизма принятия экологически значимых решений.

Роль экологического аудита в механизме принятия экологически значимых решений возросла с переходом России к рыночным экономическим отношениям, привлечением иностранных инвестиций, выходом предприятий на международный рынок. Многие иностранные инвестиции в экономику России требуют проведения обязательных программ экологического аудита. В первую очередь это требование относится к инвестициям, осуществляемым через Европейский банк реконструкции и развития и Международный банк реконструкции и развития.

При принятии решения о переходе права собственности на предприятия и иные объекты или их банкротстве требуется учет общественных интересов по охране окружающей среды. Одним из потенциально полезных инструментов обеспечения такого учета является экологический аудит.

Экологический аудит может быть использован в механизме принятия экологически значимых решений государственными органами и общественными организациями для оценки экологической составляющей деятельности предприятий и организаций любой организационно-право-

${ }^{9}$ Экологический аудит в контексте финансового аудита и аудита соответствия. ИНТОСАИ - ИССАИ 5120. - 2016. 
вой формы, а также оценки самой деятельности органов государственной власти, эффективности принятых ими решений и подготовки рекомендаций для принятия возможных управленческих решений. Экологический аудит как обязательная мера, предшествующая принятию экологически значимого решения, может проводиться по требованию государственных органов в случаях национализации и банкротства экологически опасных предприятий, а также при кредитовании государственными банками юридических лиц и граждан, осуществляющих предпринимательскую деятельность.

Имеется практика, когда заказчиком проведения экологического аудита выступали государственные органы и общественные организации. Например, по инициативе Министерства природных ресурсов Российской Федерации был проведен экологический аудит Байкальского целлюлозно-бумажного комбината, а по инициативе общественной организации «Дзержинский правозащитный центр Нижегородской области» - экологический аудит муниципального образования - города Дзержинска.

С помощью экологического аудита можно провести оценку экологических рисков приватизационных программ. От результатов проведенного экологического аудита зависят возможность и целесообразность приватизации природных ресурсов, совершения сделок с природными объектами. По итогам проведенного экологического аудита приватизируемому предприятию возможно присвоить определенный класс опасности в зависимости от степени воздействия на окружающую среду. Присвоение класса опасности порождает для предприятия юридические последствия - необходимость разработки и осуществления тех или иных природоохранных мер.

Экологический аудит может выступать элементом обязательного экологического страхования в целях определения размера страховых платежей и возмещения экологического вреда. В статье 18 Закона № 7-ФЗ закреплено, что экологическое страхование осуществляется в целях защиты имущественных интересов юридических и физических лиц на случай экологических рисков.

Посредством проведения экологического аудита собственник может принять экологически значимое решение в отношении природного ресурса или объекта. Новые собственники заинтересованы в проведении экологического аудита при приобретении прав на природные объекты и при переходе права собственности на предприятие.

Аудит как элемент обеспечения права собственности чрезвычайно важен для экономики, так как позволяет уменьшить информационный и коммерческий риск, связанный с принятием управленческих решений с целью выработки рекомендаций по эффективному использованию природных ресурсов. 
Экологический аудит может использоваться при признании права на самовольно возведенный объект недвижимости. В соответствии со статьей 49 Градостроительного кодекса РФ ${ }^{10}$ проектная документация объектов капитального строительства и результаты инженерных изысканий, выполняемых для подготовки такой проектной документации, подлежат государственной экспертизе. Однако если государственная экспертиза не проводилась, то такой объект может быть узаконен. Роль экологического аудита в данном случае заключается в оценке объекта на соответствие его экологическим требованиям и в подтверждении отсутствия угрозы причинения вреда окружающей среде. Такое решение может быть экологически значимым, если деятельность уже реализуется, например ведется стройка объекта, а государственная экспертиза не проводилась, экологический аудит позволяет провести оценку в части соблюдения экологических требований на стадии реализации объекта.

Материалы, полученные в ходе экологического аудита, могут быть использованы в судах в качестве доказательства при определении вреда, причиненного окружающей среде и здоровью граждан.

\section{2. Правовое регулирование экологического аудита}

Как отмечает один из исследователей развития экологического аудита И.Г. Иутин, в истории правового регулирования экологического аудита в России можно выделить три этапа:

первый - начало 90-х гг. XX в.,

второй - с 1993 по 1998 г.,

третий - с начала 2000 г. по настоящее время.

Первый этап характеризуется полным отсутствием правовой базы экологического аудита в Российской Федерации. В тот период единичные предприятия в целях получения международных кредитов проводят экологический аудит по технологиям, определенным международными финансовыми структурами. Второй этап характеризуется принятием нормативных правовых актов, достаточно комплексно урегулировавших отношения в области экологического аудита, закрепивших основополагающие положения (уполномоченный в данной области орган исполнительной власти, необходимые процедуры). Третий этап характеризуется отстранением государства от регулирования отношений в области экологического аудита и развитием последнего главным образом в рамках системы управления охраной окружающей среды предприятий.

10 Федеральный закон Российской Федерации от 29.12.2004 № 190-Ф3 «Градостроительный кодекс Российской Федерации». 
Понятие экологического аудита появилось в России в 1994 году, когда в постановлении Правительства Российской Федерации от 24.12.1994 № 1418, где в Положении о лицензировании отдельных видов деятельности экологический аудит был отнесен к лицензируемым видам деятельности, а за Минприроды РФ было закреплено полномочие по лицензированию деятельности в сфере «проведения экологической паспортизации, сертификации, экологического аудирования».Позднее было издано постановление Правительства Российской Федерации от 26.02.1996 № 168 «Об утверждении Положения о лицензировании отдельных видов деятельности в области охраны окружающей среды».

Полномочиями по лицензированию экологической аудиторской деятельности было наделено Минприроды России. Наделенное полномочиями Министерство охраны окружающей среды и природных ресурсов Российской Федерации издало 3 приказа:

от 11.10 .1995 № 412 «Об экологическом аудировании»;

от 29.12.1995 № 540 «Об организации экологического аудита»;

от 02.04.1998 № 95 «О создании системы аудита недропользования» (вместе с «Основными положениями аудита недропользования»).

Необходимость развития экологического аудита как первоочередная задача исполнительных органов власти была поставлена в ряде правовых актов:

распоряжение Правительства РФ от 22.11.2008 № 1734-р;

распоряжение Правительства РФ от 18.11.2011 № 2074-p;

распоряжение Правительства РФ от 29.05.2019 № 1124-р;

приказ Минпромэнерго РФ от 04.07.2006 № 141 и др.

В настоящее время документами, действующими в части регулирования экологического аудита в Российской Федерации, являются:

- приказ Госкомэкологии РФ от 30.03.1998 № 181 «Об экологическом аудировании в системе Госкомэкологии России» (далее - Приказ № 181);

- приказ Госкомэкологии РФ от 16.07.1998 № 436 «О проведении практических работ по введению экологического аудирования в Российской Федерации» (вместе с «Временным порядком аттестации экологических аудиторов») и др.

В связи с отсутствием достаточного регулирования экологического аудита на федеральном уровне в 90-е годы XX века и в настоящее время в регионах Российской Федерации принимались и принимаются правовые акты, регулирующие эту деятельность:

- Постановление Правительства Москвы от 27.08.2002 № 693-ПП»Об экологическом аудите»;

- Постановление Правительства Москвы от 22.07.2003 № 568-ПП «Об утверждении Временного положения о Системе экологического аудита в городе Москве, временного порядка проведения экологического аудита, 
критериев отнесения организаций города Москвы к числу рекомендованных для проведения экологического аудита»;

- Распоряжение главы муниципального образования «Балашихинский район» Московской области от 10.10.2003 № 962p «О проведении экологического аудита в Балашихинском районе»;

- Закон Амурской области от 10.11.2005 № 89-О3 «Об охране окружающей среды в Амурской области»;

- Постановление Администрации Костромской области от 18.03.2011 № 81-а «Об экологическом аудите на территории Костромской области» (вместе с «Временным порядком проведения экологического аудита на территории Костромской области»);

- Решение Государственной Думы Томской области от 29.02.1996 № 255 «О введении системы экологического аудита на территории Томской области» (вместе с «Временными правилами по проведению экологического аудита на территории Томской области»);

- Закон Томской области от 09.10.1997 № 574 «Об экологическом аудите в Томской области»;

- Приказ Кировского областного комитета по охране природы от 05.12.1996 № 47 «Об утверждении «Временного положения об экологическом аудите в Кировской области».

В Минприроды России в 2020 году подготовлен проект Федерального закона «Об экологическом аудите и экологической аудиторской деятельности» (См.: Приложение № 4), который проходит в настоящее время процесс обсуждения и доработки. В настоящей работе автор рассматривает данный проект как основу и вносит предложения по его дополнению и изменению.

Проведя анализ законопроекта, автор отмечает, что в настоящее время экологический аудит не входит в перечень лицензируемых видов деятельности, закрепленный Федеральный закон от 04.05.2011 № 99-ФЗ «О лицензировании отдельных видов деятельности", в части 5 статьи 8 проекта Федерального закона «Об экологическом аудите и экологической аудиторской деятельности» предусмотрено, что деятельность в области экологического аудита не является исключительной, исходя из этого, целесообразно закрепить в проекте Федерального закона не лицензирование, а саморегулирование этой деятельности. С другой стороны, целесообразно, учитывая международный опыт, сформировать в России систему профессионального саморегулирования.

Предложения автора по внесению поправок в проект Федерального закона "Об экологическом аудите и экологической аудиторской деятельности» сводятся к следующему: 


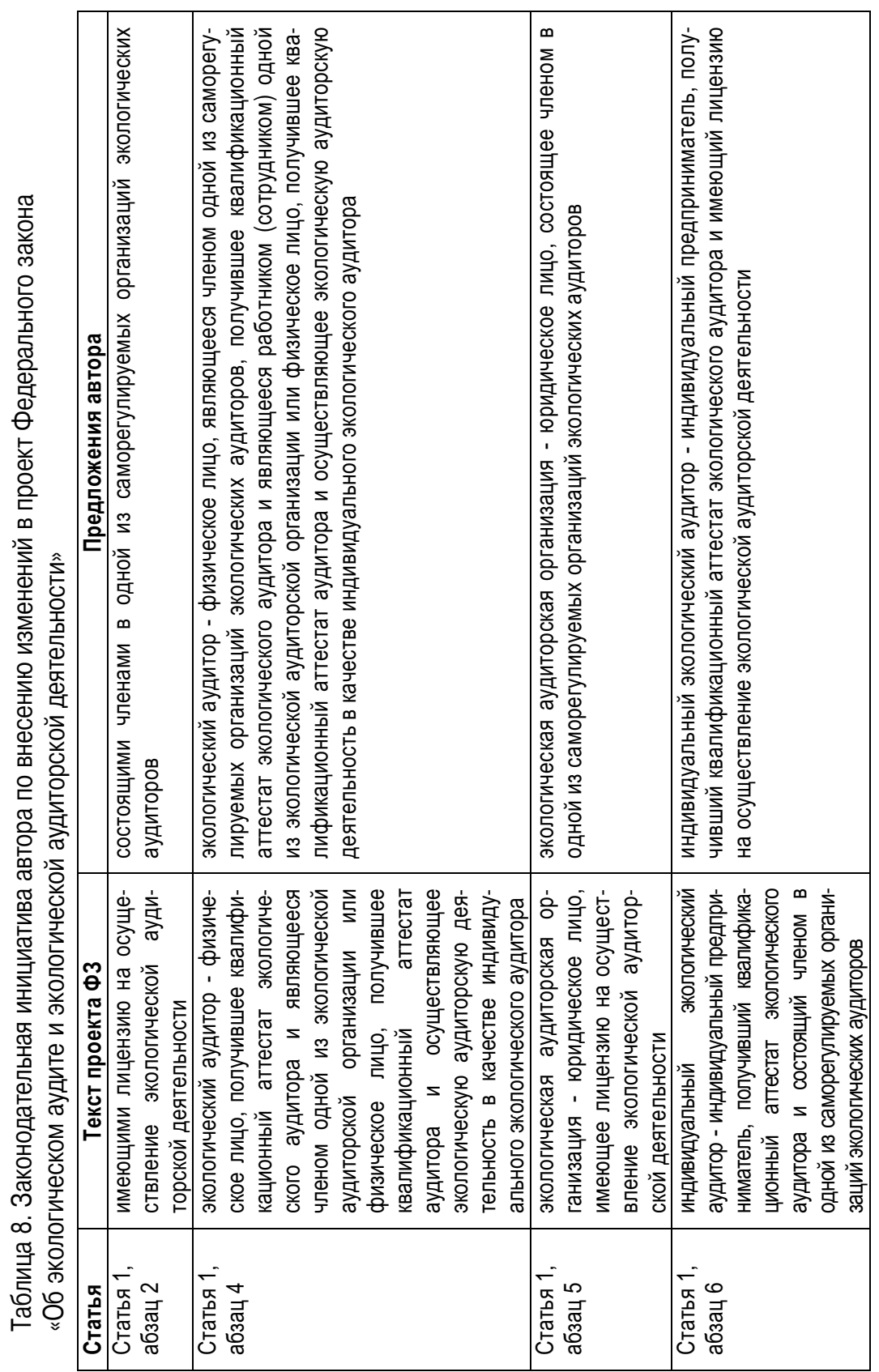




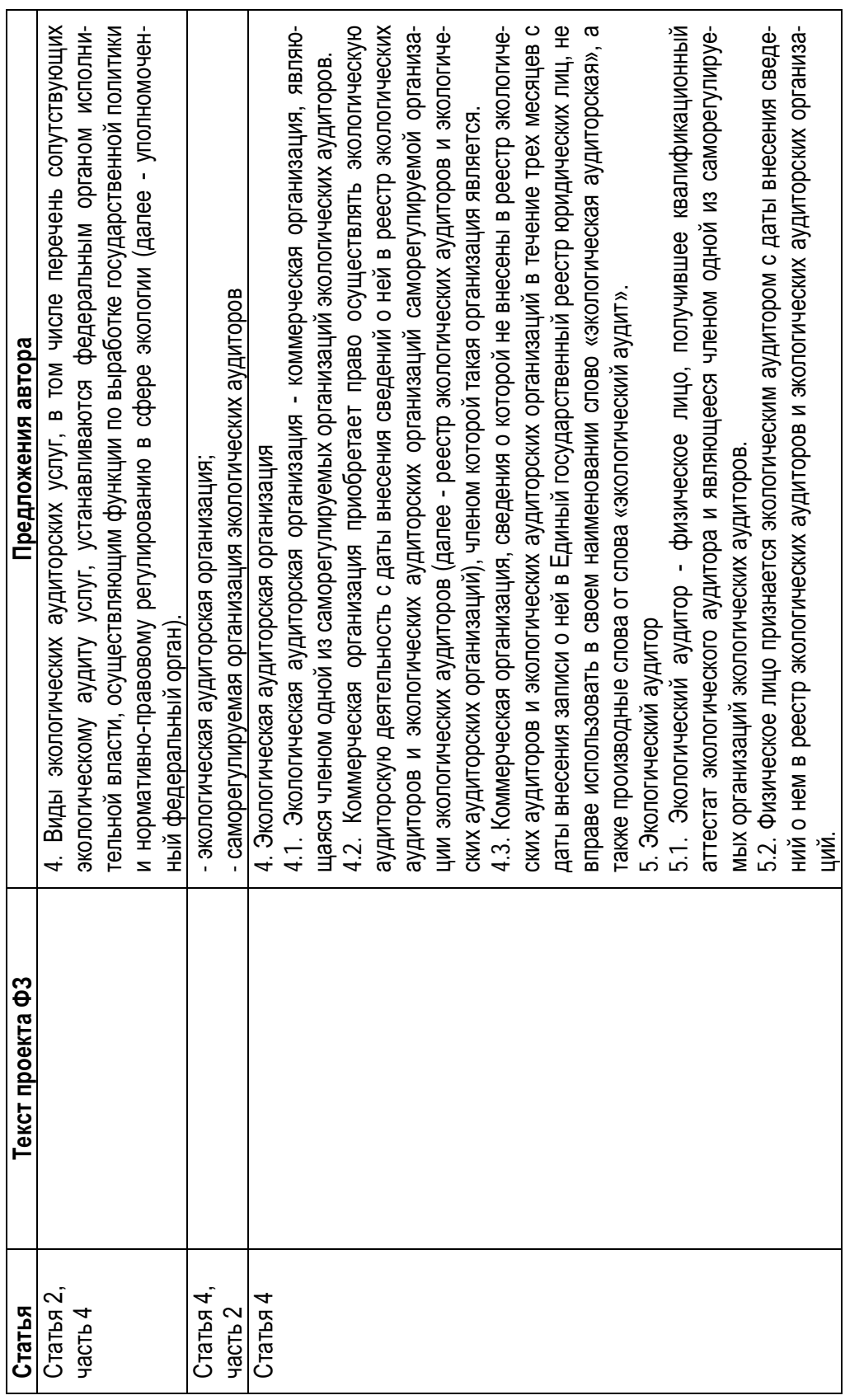




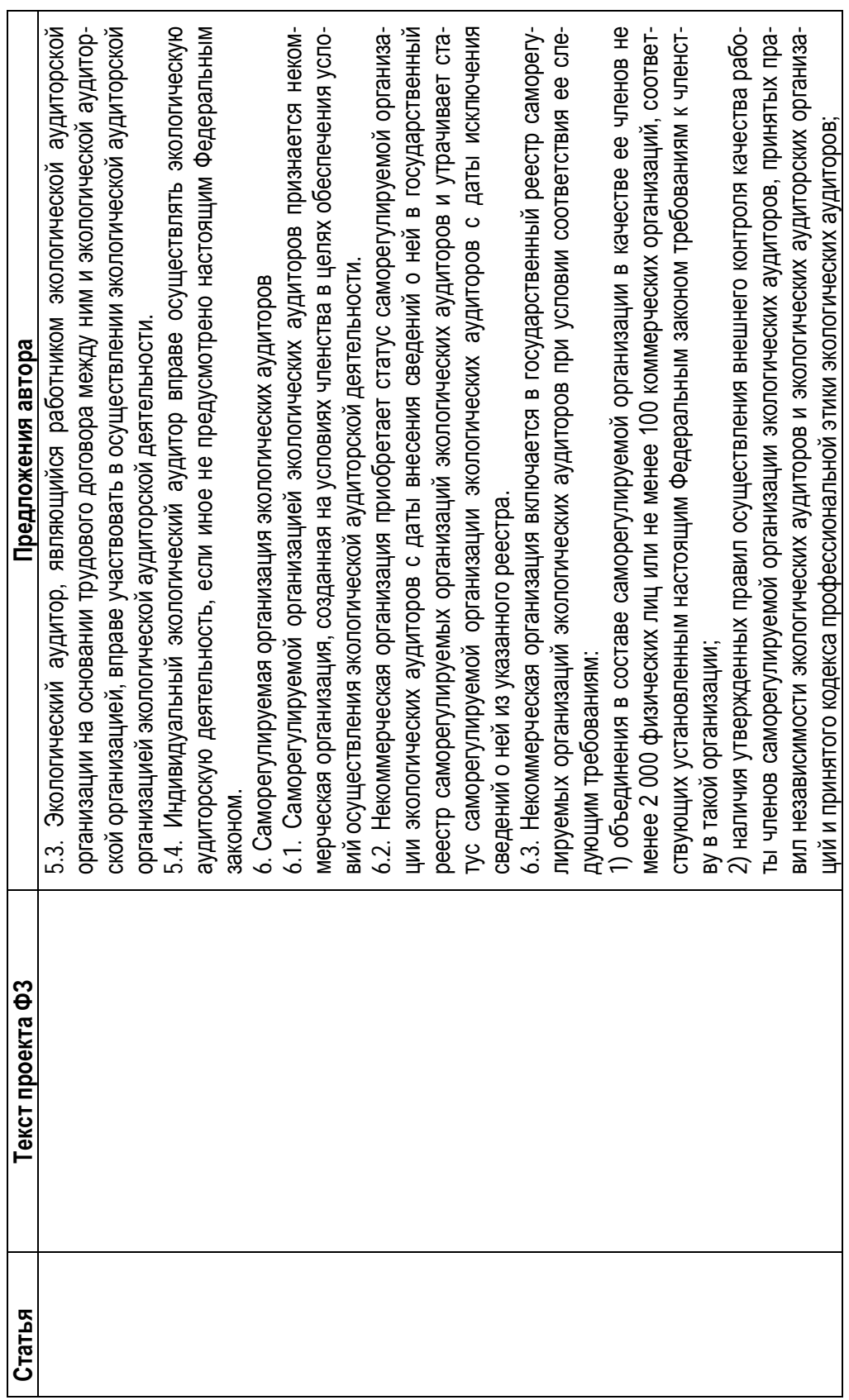




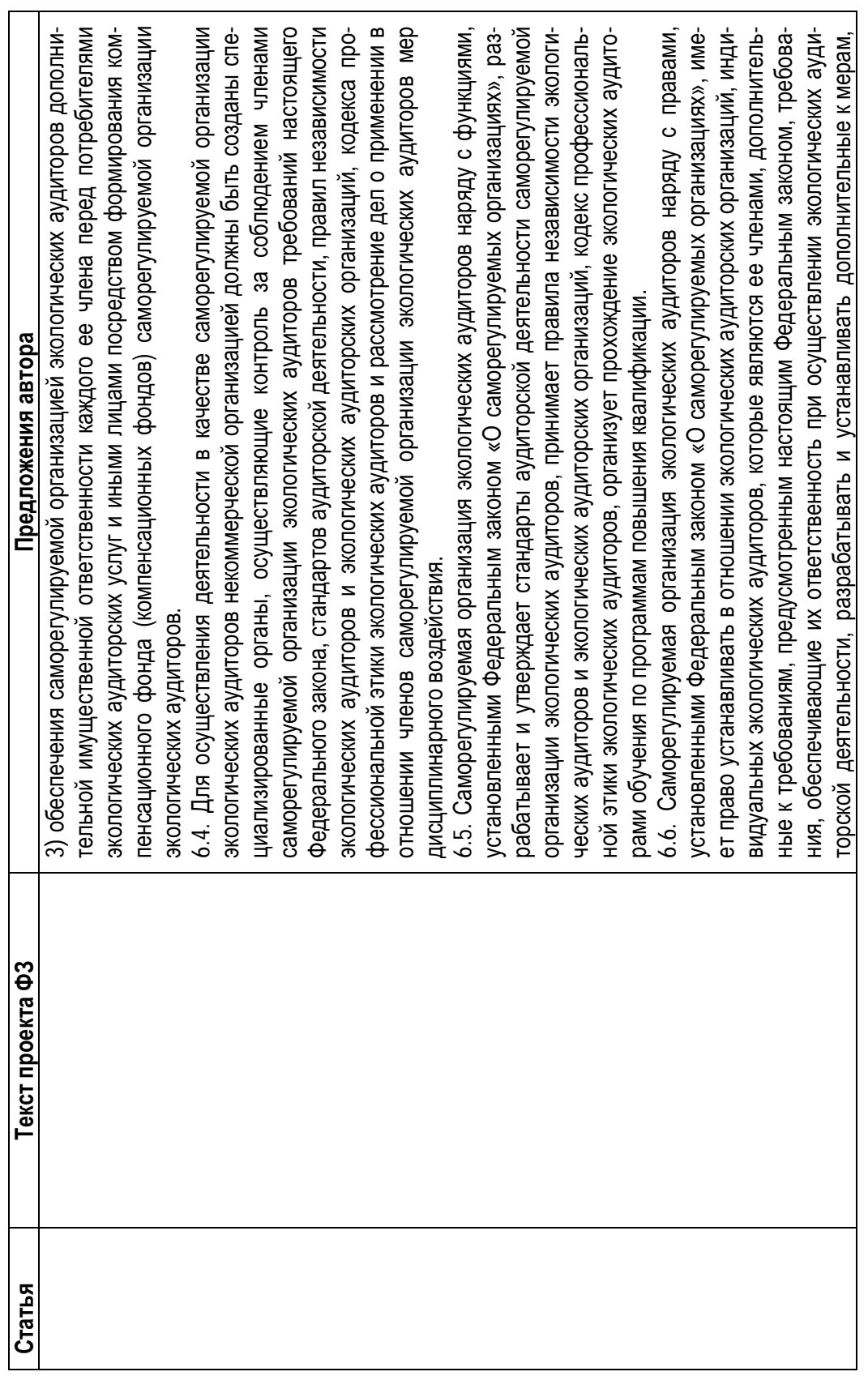




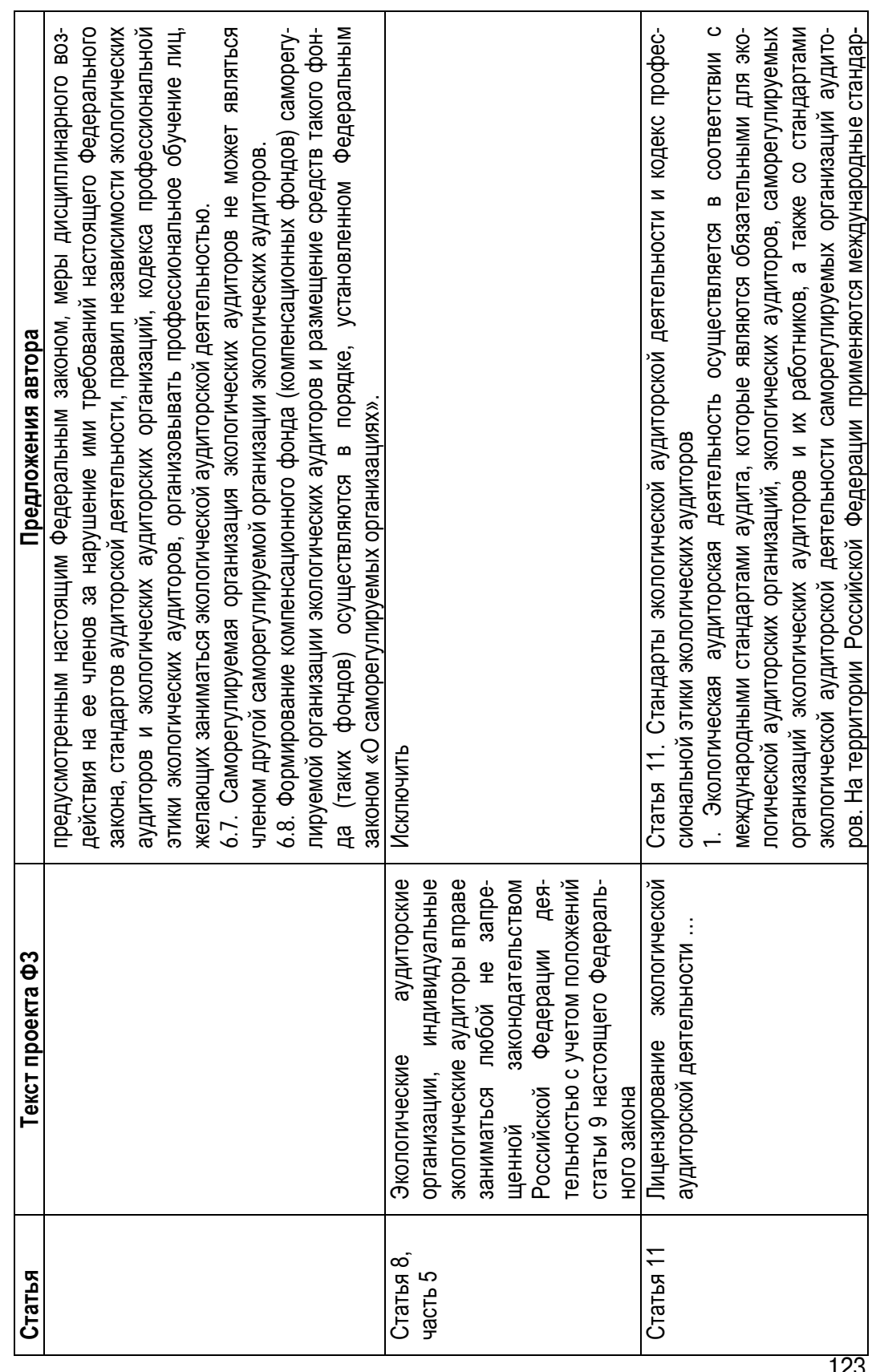




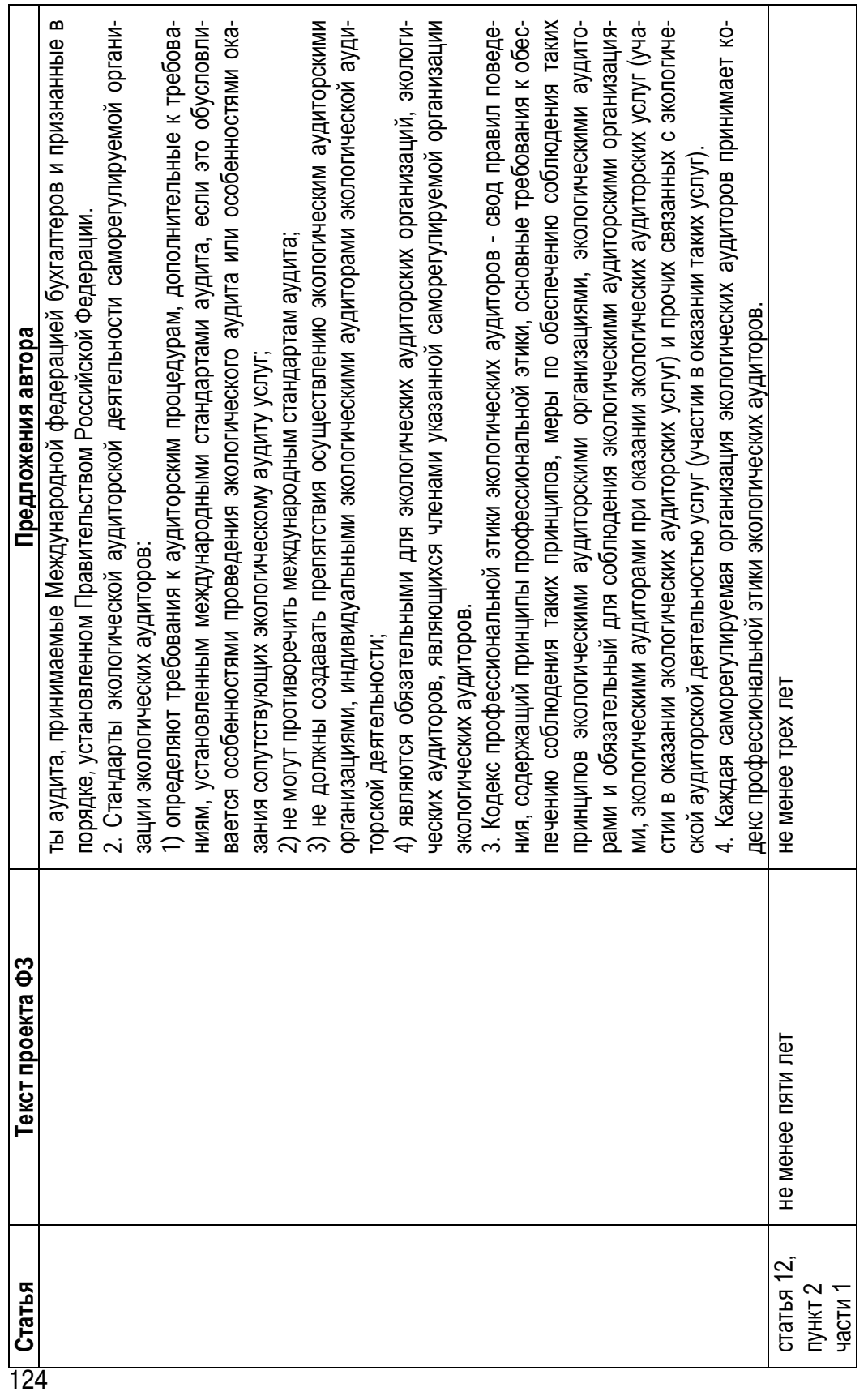




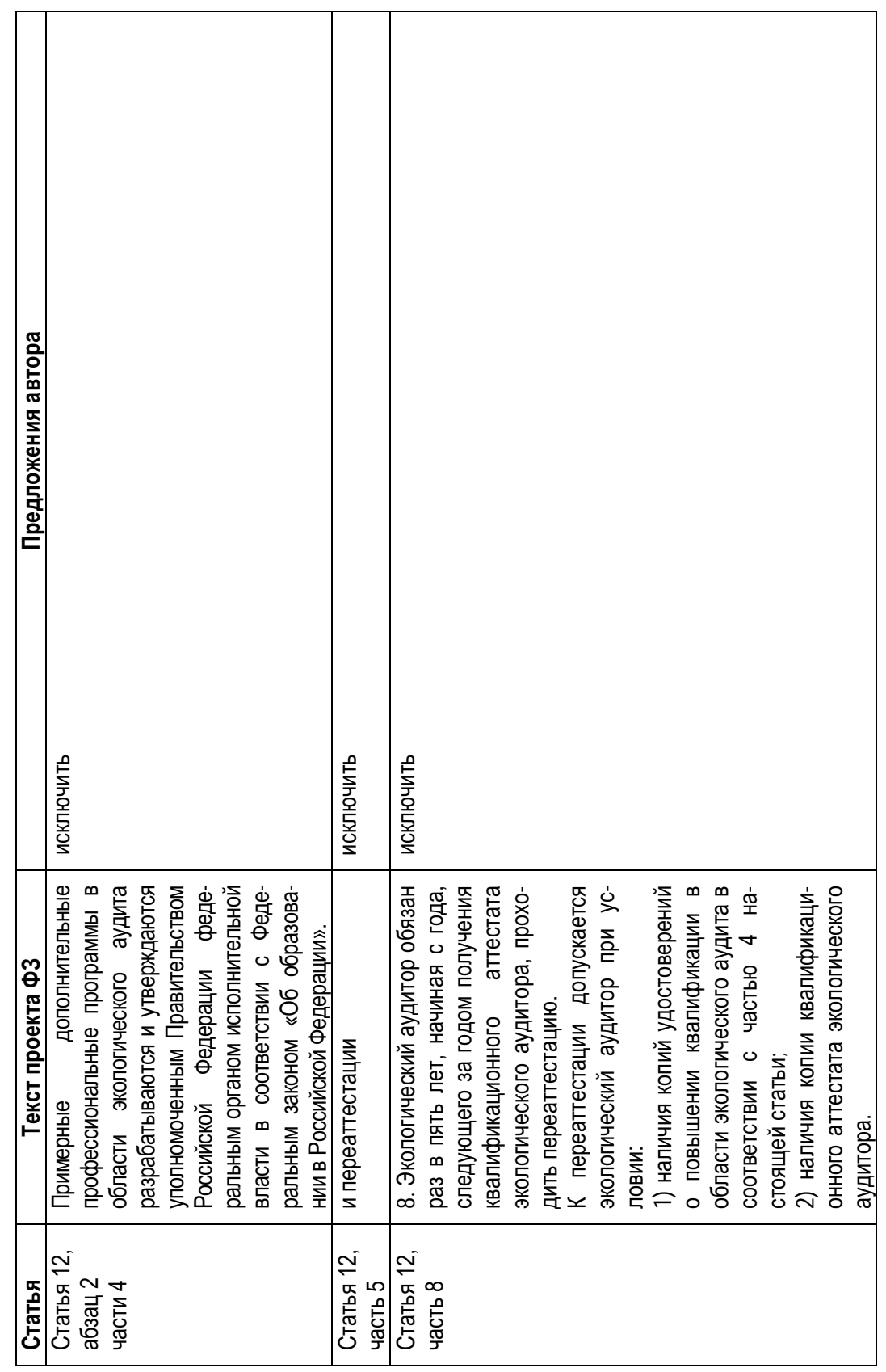




\section{3. Понятие, предмет и принципы экологического аудита}

В связи с отсутствием единых международных подходов к вопросам определения экологического аудита, в правовых источниках и литературе в настоящее время имеются различные подходы к определению понятия экологического аудита.

Определение экологического аудита в настоящее время закреплено в статье 1 Закона № 7-ФЗ: «экологический аудит - независимая, комплексная, документированная оценка соблюдения юридическим лицом или индивидуальным предпринимателем требований, в том числе нормативов и нормативных документов, федеральных норм и правил, в области охраны окружающей среды, требований международных стандартов и подготовка рекомендаций по улучшению такой деятельности».

Определение понятия «экологический аудит» было также дано в стандартах ГОСТ Р ИСО 14050-9911. Стандарты устанавливали, что экологический аудит - это систематический документально оформленный процесс проверки объективно получаемых и оцениваемых аудиторских данных для определения соответствия или несоответствия критериям аудита определенных видов экологической деятельности, событий, условий, систем административного управления или информация об этих объектах, а также сообщение результатов, полученных в итоге этого процесса, клиенту.

Таким образом, можно констатировать, что внормативных правовых документах Российской Федерации содержатся несколько вариантов определения экологического аудита (Таблица 9, стр. 126).

Под экологическим аудитом можно также понимать проверку и оценку состояния деятельности юридических лиц и граждан-предпринимателей по обеспечению рационального природопользования и охраны окружающей среды от вредных воздействий, включая состояние очистного и технологического оборудования, их соответствие требованиям законодательства Российской Федерации, проводимые для выявления прошлых и существующих экологически значимых проблем в целях подготовки и принятия обоснованных экологически значимых решений.

Ряд ученых определяют экологический аудит как разновидность экологического надзора и контроля. В рамках этого подхода экологический аудит рассматривается как оценка воздействия предприятия на окружающую среду с целью засвидетельствования соответствия его деятельности нормам, требованиям, стандартам охраны окружающей среды.

По мнению ряда авторов, экологический аудит - это природоохранная и предпринимательская деятельность, направленная, в первую очередь, на повышение эффективности экологического менеджмента, включая оценку соответствия действующему природоохранительному законодательству.

11 В настоящее время не действуют. 


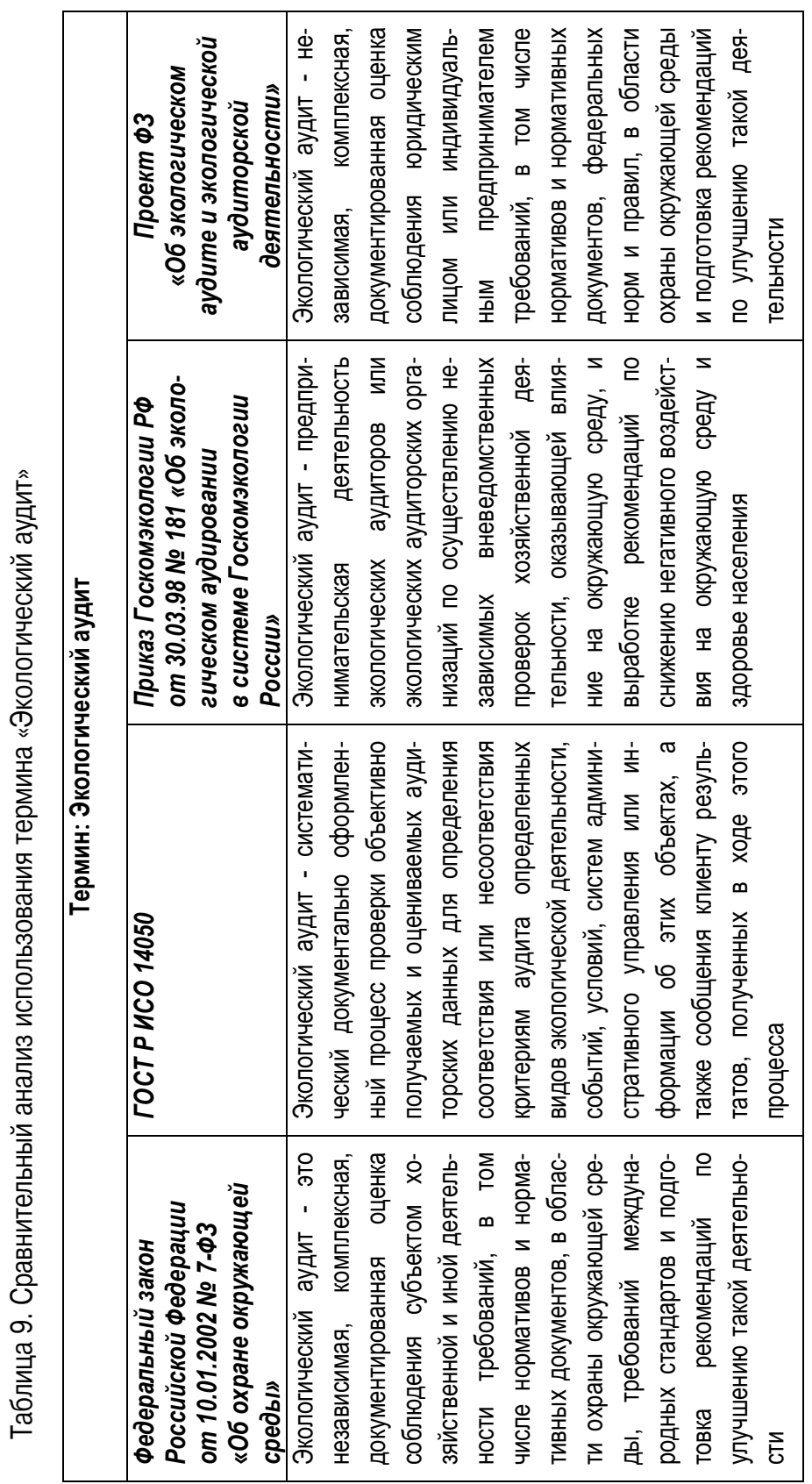


Сторонники данного подхода к пониманию природы экологического аудита практически ограничивают содержание экологического аудита оценкой соответствия деятельности хозяйствующего субъекта требованиям охраны окружающей среды, закрепленным в действующем законодательстве, с целью минимизации техногенного воздействия на окружающую среду. Предлагаемые критерии экологического аудита сведены либо к оценке объемов выбросов загрязняющих веществ в атмосферу, почву, в водные объекты и др., либо к оценке объемов изъятия, либо к оценке ущерба, наносимого окружающей среде.

Большое распространение в научной литературе получило понимание экологического аудита как механизма обеспечения безопасности в экологической сфере.

В настоящее время вопросы экологического аудита являются предметом пристального внимания стран пост-советского пространства. На 39 пленарном заседании Межпарламентской Ассамблеи государств-участников СНГ постановлением от 29.11.2013 № 39-5, с учетом имеющегося в странах СНГ опыта, был принят модельный закон «Об экологическом аудите»12.

В Казахстане с 2007 года действует Экологический кодекс Республики Казахстан ${ }^{13}$. В нем отдельная глава посвящена экологическому аудиту, целями которого признаны:

а) проверка достоверности представленной отчетности о воздействии на окружающую среду;

б) оценка соответствия производственно-технологического процесса экологическим требованиям;

в) оценка соответствия системы производственного мониторинга и контроля экологическим требованиям;

г) оценка уровня квалификации работников.

Вместе с тем, в январе текущего года в Казахстане была принята новая редакция кодекса, в которой указанная глава отсутствует ${ }^{14}$.

В статье 1 Закона Республики Беларусь «Об охране окружающей среды» ${ }^{15}$ дано следующее определение экологическому аудиту: это независимая комплексная документированная проверка соблюдения юридическими лицами и индивидуальными предпринимателями, осуществляющими хозяйственную и иную деятельность, требований, в том числе нормативов и технических нормативных правовых актов, в области охраны окружающей

${ }^{12}$ См.: Модельный закон «Об экологическом аудите» (принят на 39 пленарном заседании Межпарламентской Ассамблеи государств-участников СНГ - постановление от 29.11.2013 № 39-5).

${ }^{13}$ Экологический кодекс Республики Казахстан от 09.01.2007 № 212-III ЗРК.

${ }^{14}$ Экологический кодекс Республики Казахстан от 02.01.2021 № 400-VI ЗРК.

${ }^{15}$ Закон Республики Беларусь от 26 ноября 1992 № 1982-XII «Об охране окружающей среды». 
среды, требований международных стандартов и подготовка рекомендаций по снижению (предотвращению) вредного воздействия такой деятельности на окружающую среду.

Статья 97 Закона Республики Беларусь «Об охране окружающей среды» устанавливает, что:

«Экологический аудит проводится в целях обеспечения экологической безопасности, определения путей и способов уменьшения риска вредного воздействия на окружающую среду хозяйственной и иной деятельности путем независимой проверки такой деятельности на соответствие требованиям в области охраны окружающей среды.

Экологический аудит проводится юридическими лицами или индивидуальными предпринимателями в порядке, установленном Советом Министров Республики Беларусь. Лица, проводящие экологический аудит, могут оказывать услуги в выработке решений по повышению экологической безопасности производства на проверяемых объектах.

Экологический аудит хозяйственной и иной деятельности юридических лиц или индивидуальных предпринимателей может проводиться в добровольном или обязательном порядке за счет собственных средств этих юридических лиц или индивидуальных предпринимателей.

При приватизации предприятий как имущественных комплексов государственных унитарных предприятий, а также в иных случаях, установленных настоящим Законом и другими законодательными актами, в обязательном порядке проводится экологический аудит в соответствии с законодательством».

В Украине принят Закон «Об экологическом аудите» ${ }^{16}$, который определяет основные правовые и организационные основы осуществления экологического аудита и направлен на повышение экологической обоснованности и эффективности деятельности субъектов хозяйствования.

В статье 1 данного Закона установлено, что экологическим аудитом является документально оформленный системный независимый процесс оценивания объекта экологического аудита, включающий сбор и объективное оценивание доказательств для установления соответствия определенных видов деятельности, мер, условий, системы управления окружающей природной средой и информации по этим вопросам требованиям законодательства Украины об охране окружающей природной среды и другим критериям экологического аудита.

Автор придерживается следующего определения термина и вида деятельности:

Экологический аудит - профессиональная предпринимательская деятельность, направленная на независимую, комплексную, документированную оценку соблюдения юридическим лицом или индивидуальным пред-

${ }^{16}$ Закон Украины от 24 июня 2004 № 1862-IV «Об экологическом аудите». 
принимателем требований, в том числе нормативов и нормативных документов, федеральных норм и правил, в области охраны окружающей среды и подготовку рекомендаций по улучшению такой деятельности.

Для определения места экологического аудита в системе экологического управления необходимо в первую очередь установить, каковы задачи, принципы и содержание данной деятельности.

В соответствии с пунктом 6 Приказа № 181 в задачи экологического аудита входит:

обоснование экологической стратегии и политики предприятия;

определение приоритетов при планировании природоохранной деятельности предприятия, выявление дополнительных возможностей ее осуществления;

проверка соблюдения субъектом хозяйственной деятельности природоохранительного законодательства;

повышение эффективности регулирования воздействия субъекта хозяйственной деятельности на окружающую среду;

снижение риска возникновения чрезвычайных ситуаций, связанных с загрязнением окружающей среды.

Ряд авторов к задачам экологического аудита относят:

оценку функционирования организационной структуры, управления и оборудования предприятия с точки зрения охраны окружающей среды, рационального использования природной среды и обеспечения экологической безопасности, а также

выработку на этой основе рекомендаций как по предотвращению и устранению негативных последствий осуществляемой деятельности, так и по оптимизации организации работ, повышению ее эффективности.

Что касается содержания аудита, то, экологический аудит выходит за рамки ревизии финансовой отчетности, к чему обязывает сам термин «экологический». Исходя из задач экологического аудита, его содержание представляет собой оценку функционирования предприятия и выработку соответствующих рекомендаций.

Согласно пункту 4 Приказа № 181 основные принципы экологического аудита:

объективность и независимость экологических аудиторов от проверяемого субъекта хозяйственной деятельности, собственников и руководителей экологических аудиторских организаций и третьих лиц при проведении экологического аудита;

профессионализм и компетентность экологических аудиторов в вопросах охраны окружающей среды, природопользования и специфики обследуемого субъекта хозяйственной деятельности;

достоверность и полнота информации, предоставляемой субъектом хозяйственной деятельности; 
планирование работ по проведению экологического аудита;

комплексность экологического аудита (охват всех аспектов воздействия на окружающую среду);

конфиденциальность информации, полученной в результате проведения экологического аудита;

ответственность экологических аудиторов за результаты проводимых исследований.

Ряд авторов высказывает сомнение в правильности отнесения профессионализма к принципам экологического аудита. В защиту данного принципа автор указывает на следующее: к сожалению, в настоящее время получить документ дающий право на проведение экологического аудита может лицо, имеющее любое образование. Интернет пестрит рекламными объявлениями о проведении аудита соответствия ISO. Вместе с тем, экология специфическая отрасль деятельности, требующая от специалиста наличия профессиональных знаний в химии, биологии и ряде других наук. В численный состав фирмы, занимающейся экологическим аудитом, и в состав аудиторской экологической проверки, безусловно, могут входить специалисты в области права, учета и других областей знаний, но квалификационный документ на право заниматься этим профессиональным видом деятельности должен выдаваться только лицу, имеющему, как минимум, или высшее образование со специализацией «химия и биология», или высшее образование (любое) и диплом о переподготовке по специальности «экология».

\section{4. Виды экологического аудита}

В Российской Федерации в настоящее время согласно пункта 5 Приказа № 181 экологический аудит может быть обязательным и инициативным.

Обязательный экологический аудит проводится в случаях, прямо установленных нормативными правовыми актами Российской Федерации.

Инициативный экологический аудит проводится по решению субъекта хозяйственной деятельности, определяющего цели и задачи проведения экологического аудита.

Вместе с тем, в региональном законодательстве имеются разночтения.

В соответствии со статьей 4 Закона Томской области от 09.10.1997 № 574 «Об экологическом аудите в Томской области» на территории Томской области могут осуществляться инициативный и обязательный виды экологического аудита. Инициативный экологический аудит проводится экологической аудиторской организацией, аудитором, осуществляющим предпринимательскую деятельность без образования юридического лица, по решению хозяйствующего субъекта. Обязательный экологический аудит проводится экологической аудиторской организацией по решению органов государственной власти. Обязательный экологический аудит прово- 
дится: при обосновании инвестиционных проектов и программ в случае, если это предусмотрено условиями инвестирования; при обосновании и реализации экологических программ (федеральных, региональных, местных, отдельных природопользователей), финансируемых за счет бюджетных и внебюджетных источников; при лицензировании отдельных видов деятельности в случаях, предусмотренных нормативными правовыми актами Российской Федерации.

Согласно статье 12 Закона Амурской области от 10.11.2005 № 89-03»Об охране окружающей среды в Амурской области» первоочередному экологическому аудиту подлежат опасные производственные объекты, отнесенные к данной категории в соответствии с Федеральным законом «О промышленной безопасности опасных производственных объектов».

Ряд авторов рассматривают обязательный экологический аудит как перекладывание со стороны государственных органов их обязанности по осуществлению государственного экологического надзора объектов хозяйственной и иной деятельности на негосударственные организации (причем за счет средств самих аудируемых). Мы не можем с этим согласиться. Аналогичным порядком выстраивается в российской Федерации и в мире регулирование и иных профессий: оценщиков, финансовых аудиторов и др.

Положения об обязательном экологическом аудите закреплены в проекте Федерального закона «Об экологическом аудите и экологической аудиторской деятельности» в котором установлено:

Обязательный экологический аудит проводится в случаях:

1) осуществления лицензируемых видов деятельности по обращению с отходами I - III классов опасности (один раз в три года) - проводится оценка соответствия хозяйственной и (или) иной деятельности, документов в области охраны окружающей среды аудируемого лица требованиям в области охраны окружающей среды в части обращения с отходами I - III классов опасности;

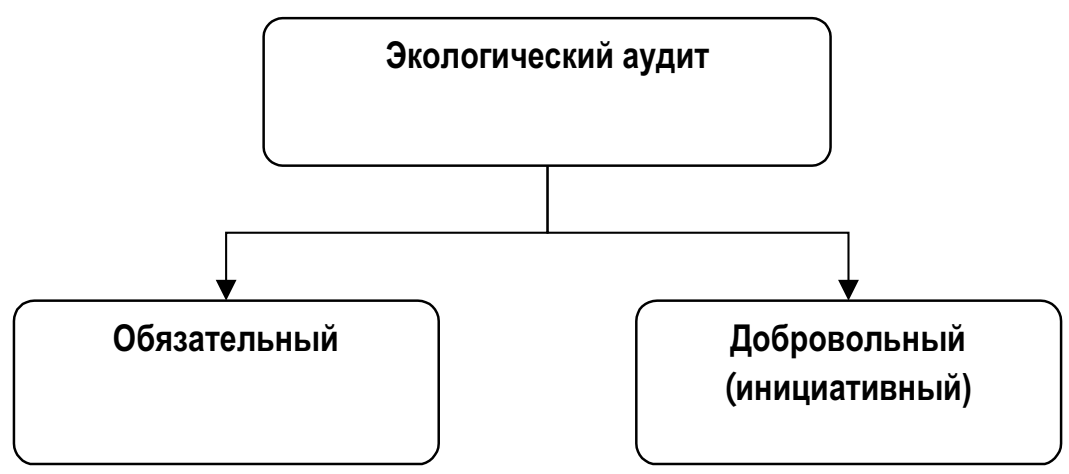

Рисунок 3. Виды экологического аудита 
2) осуществления деятельности по утилизации, размещению и обезвреживанию отходов IV - V классов опасности на объектах, оказывающих негативное воздействие на окружающую среду, I и II категории (один раз в три года) - проводится оценка соответствия хозяйственной и (или) иной деятельности, документов в области охраны окружающей среды аудируемого лица требованиям в области охраны окружающей среды в части утилизации, размещения и обезвреживания отходов IV - V классов опасности;

3) реализации проекта восстановительных работ в целях возмещения вреда окружающей среде, причиненного нарушением законодательства в области охраны окружающей среды, на основании решения суда (не позднее шести месяцев после окончания реализации проекта восстановительных работ в целях возмещения вреда окружающей среде, причиненного нарушением законодательства в области охраны окружающей среды)проводится оценка соответствия отчета о выполнении проекта восстановительных работ и результатов выполнения мероприятий указанного проекта требованиям в области охраны окружающей среды в части возмещения вреда окружающей среде;

4) выполнения мероприятий специальных экологических программ реабилитации радиационно загрязненных участков территории (не позднее шести месяцев после выполнения мероприятия специальной экологической программы реабилитации радиационно загрязненных участков территории) - проводится оценка соответствия отчета о выполнении мероприятий специальных экологических программ радиационно загрязненных участков территории и результатов выполнения мероприятий указанных программ требованиям в области охраны окружающей среды, включая радиационного воздействия, в части реабилитации радиационно загрязненных участков территории;

5) принятия решения о признании должника банкротом и об открытии конкурсного производства в отношении должника, признанного банкротом и осуществлявшего деятельность на объектах, оказывающих негативное воздействие на окружающую среду, I и II категории (на этапе открытия конкурсного производства, в соответствии с требованиями, установленными Федеральным законом от 26.10.2002 № 127-Ф3 «О несостоятельности (банкротстве)») - проводится оценка соответствия имущества и документов в области охраны окружающей среды должника требованиям в области в охраны окружающей среды в части наличия задолженностей по плате за негативное воздействие на окружающую среду, обязанности восстановления нарушенного состояния окружающей среды в результате деятельности указанного объекта;

6) принятия решения о приватизации объектов, оказывающих негативное воздействие на окружающую среду, I и II категории (на этапе информа- 
ционного обеспечения приватизации государственного или муниципального имущества, в соответствии с требованиями, установленными Федеральным законом от 21.12.2001 № 178-Ф3 «О приватизации государственного и муниципального имущества») - проводится оценка имущества, подлежащего приватизации, и документов в области охраны окружающей среды требованиям в области охраны окружающей среды в части наличия задолженностей по плате за негативное воздействие на окружающую среду, обязанности восстановления нарушенного состояния окружающей среды в результате деятельности указанного объекта.

Добровольный экологический аудит проводится по инициативе заказчика экологического аудита.

Автор отмечает, что в литературе встречается также и иное наименование инициативного аудита - добровольный.

Инициативный (добровольный) экологический аудит может быть:

комплексным аудитом;

технологическим аудитом.

При проведении комплексного аудита осуществляется оценка соответствия хозяйственной и (или) иной деятельности, документов в области охраны окружающей среды, иных объектов аудируемого лица требованиям в области охраны окружающей среды в части рационального использования и охраны недр, использования и охраны земель, обращения с отходами, охраны атмосферного воздуха, использования и охраны водных объектов, особо охраняемых природных территорий, государственной экологической экспертизы.

При проведении технологического аудита осуществляется оценка соответствия хозяйственной и (или) иной деятельности на объекте, оказыва-

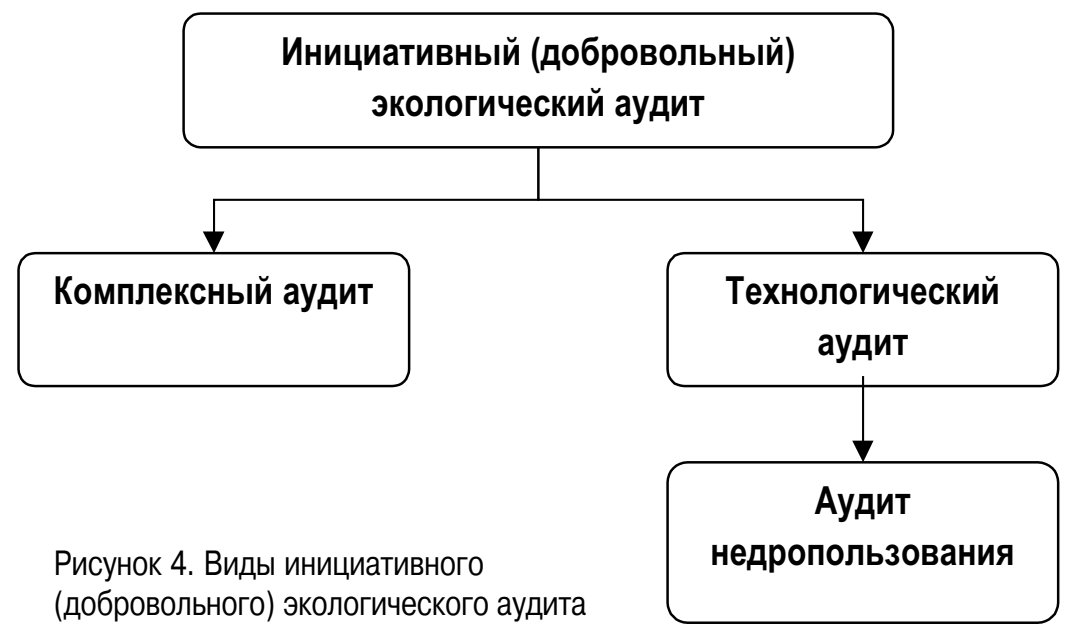


ющем негативное воздействие на окружающую среду, обязательным для выполнения требованиям в области охраны окружающей среды, установленных комплексным экологическим разрешением.

В частности, автор рассматривает процедуру верификации экологических проектов (проектов устойчивого развития. «зеленых» и переходных проектов) как разновидность технологического аудита. Более подробно эту разновидность аудиторской деятельности автор рассматривает в главе 3 настоящей монографии.

К разновидности технологического аудита, по мнению автора, следует отнести и сертификацию соответствия системы экологического менеджмента (аудит соответствия системы экологического менеджмента) ISO 14001:2015 (ГОСТ Р ИСО 14001-2015). Автор не считает целесообразным в данной работе подробно описывать процедуры проверки соответствия системы экологического менеджмента.

Другим примером технологического аудита может быть аудит недропользования. Аудит недропользования может проводиться по заявке заказчика на этапе выбора объекта недропользования, выставленного на конкурс или аукцион. Проводиться он должен на основании договора, заключенного между аудиторской организацией и заказчиком. В этом случае аудиторская фирма должна давать рекомендации о целесообразности подачи заявки на участие в конкурсе (аукционе) по конкретным объектам недропользования с учетом всех рисковых составляющих в процессе проведения работ, а также оказывать иные консультационные услуги. Аудиторское заключение по конкурсным объектам дается на основе геологической информации, реализуемой организаторами конкурса с дополнительным использованием сведений по данному региону, имеющихся у заказчика. Такой аудит позволит минимизировать затраты претендента на получение права пользования недрами для диверсификации средств в другие, менее затратные проекты. В настоящее время, после процедур получения права пользования недрами и затратив на такие процедуры значительные средства, у недропользователя часто недостает средств для реализации мероприятий, связанных с процессом пользования недрами.

В случае если аудиторская проверка осуществлена по инициативе недропользователя, результаты отчетов (заключений) аудиторских организаций должны учитываются контрольно-надзорными органами не только как информация о деятельности недропользователя, но и при применении мер ответственности.

В процессе проведения аудита недропользования должен осуществляться анализ:

- достоверности информации и разработки рекомендаций, необходимых для рационального использования недр и природных ресурсов при 
разработке полезных ископаемых, обеспечения использования подземного пространства в рамках существующих норм и правил, соблюдения безопасности жизнедеятельности населения и охраны окружающей среды в районах горных работ;

- осуществления контроля за исполнением лицензионных условий на недропользование, в части недопущения незаконной переуступки лицензий, безлицензионного (самовольного) пользования недрами, своевременного и правильного внесения платежей при пользовании недрами, а также соблюдением норм экологического права.

Основные задачи аудита недропользования:

- определение направлений повышения рационального и комплексного использования природных ресурсов, охраны недр и окружающей среды;

- контроль за выполнением условий соглашений (договоров) о разделе продукции в части поисков, разведки и добычи минерального сырья, раздела произведенной продукции, а также ее транспортировки, обработки, хранения на стадиях процессов заключения, исполнения и прекращения соглашений (договоров) о разделе продукции;

- контроль за исполнением лицензионных условий на недропользование, в части недопущения незаконной переуступки лицензий, безлицензионного (самовольного) пользования недрами, своевременного и правильного внесения платежей за право пользования недрами;

- снижение отрицательного воздействия недропользования на окружающую природную среду, на здоровье населения и персонала предприятийнедропользователей;

- подготовка рекомендаций по совершенствованию финансово-хозяйственной деятельности субъектов недропользования.

Кроме этого, аудит недропользования - процедура проверки деятельности недропользователей на соответствие нормативным актам в сфере недропользования и охраны окружающей среды и выработке рекомендаций по повышению эффективности использования ресурсов недр.

Объектами аудита недропользования являются:

- предприятия по добыче полезных ископаемых на стадии разведки, опытной и промышленной эксплуатации, консервации, включая систему транспортировки сырья и продукции и управления горно-геологическими отходами;

- предприятия, использующие шахты, тоннели, бункеры, резервуары и иные подземные сооружения для переработки, транспортировки, хранения сырья и продукции;

- специальные транспортные подземные сооружения (метрополитены и пр.);

- системы подземных коммуникаций, используемые для транспортировки и передачи воды, различных энергоносителей, электроэнергии; 
- подземные полигоны отходов, в том числе радиоактивных, на стадии оборудования, эксплуатации и консервации, включая систему транспортировки отходов и их производных.

Субъектами аудита недропользования являются органы государственной власти и аудиторские организации.

Однако в соответствии с постановлением Правительства Российской Федерации от 13.08.1997 № 1009 «Об утверждении Правил подготовки нормативных правовых актов федеральных органов исполнительной власти и их государственной регистрации» приказ Минприроды России от 02.04.1998 № 95 применяться не может, так как он не был зарегистрирован в Министерстве юстиции Российской Федерации и не был опубликован.

В результате в настоящее время административные механизмы управления государственным фондом недр и охраной окружающей среды в процессе недропользования не развиты, в то же время регулирование договорными процедурами, включая экономические средства, отсутствует.

Следовательно, в законодательстве Российской Федерации о недрах необходимо предусмотреть нормы, регулирующие отношения, связанные с аудитом недропользования (горным аудитом). В связи с этим следует придать приказу Министерства природных ресурсов Российской Федерации от 02.04.1998 № 95 «0 создании системы аудита недропользования», которым были утверждены Основные положения аудита недропользования, статус нормативного правового акта, предварительно доработав его с учетом современных требований к аудиту.

Министерством природных ресурсов Российской Федерации был также издан приказ от 31.08.1999 № 169 «Об утверждении Временного положения об аудите недропользования на предприятиях топливно-энергетического комплекса». Однако из-за отказа Минюста России в государственной регистрации этого приказа он был отменен приказом Минприроды России от 06.06.2001 № 481.

Горный аудит должен проводиться в следующих случаях:

- по инициативе государственных контрольно-надзорных органов в сфере недропользования;

- по инициативе органов государственной власти, финансовых, кредитных и других заинтересованных органов по согласованию с руководством или собственником предприятия;

- по инициативе собственника предприятия или организации с целью проверки соблюдения им требований и выработки соответствующих корректирующих мер, повышающих эффективность использования недр;

- по инициативе потенциального пользователя недр с целью выбора оптимального объекта недропользования, выставленного на конкурс или аукцион. 
В организационно-правовой деятельности аудита недропользования следует установить следующие ограничения:

- аудит недропользования не может проводиться аудиторскими организациями в отношении юридических лиц, являющихся их учредителями, акционерами, кредиторами, страховщиками, а также в отношении которых эти аудиторские организации являются учредителями, акционерами или дочерними предприятиями;

- аудит недропользования не может проводиться аудиторами, являющимися собственниками, акционерами, руководителями и иными должностными лицами проверяемого предприятия-недропользователя.

Аудит должен проводиться на основании договора, заключенного между аудиторской организацией и заказчиком. Процедура аудита должна предусматривать оформление его результатов в виде аудиторского заключения, представляемого заказчику, если иное не предусмотрено договором. Опыт систематизации экологического аудита есть и в странах постсоветского пространства.

В Экологическом кодексе Республики Казахстан определяются основания для проведения обязательного экологического аудита физических и юридических лиц; подробно регламентируются процедуры осуществления экологического аудита, устанавливаются права и обязанности субъектов экоаудиторских правоотношений, требования и к индивидуальным экологическим аудиторам, и к экологическим аудиторским организациям, и к экологическим аудиторским отчетам. Также необходимо иметь в виду, что деятельность по экологическому аудиту является лицензируемой.Кроме того, предусматривается проведение инициативного и обязательного экологического аудита.

Экологический аудит на Украине проводится в процессе приватизации объектов государственной собственности, другого изменения формы собственности, изменения конкретных собственников объектов для потребностей экологического страхования в случае передачи объектов государственной и коммунальной собственности в долгосрочную аренду, концессию, создания на основе таких объектов общих предприятий, создания, функционирования и сертификации систем управления окружающей природной средой, а также осуществления хозяйственной и другой деятельности.

Экологический аудит в Украине может быть добровольным или обязательным. Обязательный экологический аудит осуществляется на основании решения заинтересованных органов исполнительной власти или органов местного самоуправления в следующих случаях:

а) банкротство;

б) приватизация, передача в концессию объектов государственной и коммунальной собственности; 
в) передача или приобретение в государственную или коммунальную собственность, передача в долгосрочную аренду объектов государственной или коммунальной собственности;

г) создание на основе объектов государственной и коммунальной собственности общих предприятий;

д) экологическое страхование объектов;

е) завершение действия соглашения о распределении продукции согласно закону;

ж) и др.

Экологический аудит в Республике Белоруссия проводится по направлениям:

использование и охрана вод;

использование и охрана земель (включая почвы);

охрана атмосферного воздуха и озонового слоя;

обращение с отходами; обращение с опасными химическими веществами; обращение с объектами растительного мира;

обращение с объектами животного мира;

использование и охрана недр;

иные направления хозяйственной и иной деятельности.

\section{5. Объекты экологического аудита}

Проект Федерального закона «Об экологическом аудите и экологической аудиторской деятельности» к объектам экологического аудита относит:

1) хозяйственную и (или) иную деятельность юридических лиц и индивидуальных предпринимателей, оказывающую негативное воздействие на окружающую среду;

2) документы в области охраны окружающей среды;

3) имущество, используемое юридическими лицами или индивидуальными предпринимателями в целях осуществления хозяйственной и (или) иной деятельности юридических лиц и индивидуальных предпринимателей, на объекте, оказывающем негативное воздействие на окружающую среду.

В соответствии с Положением о порядке проведения экологического аудита ${ }^{17}$, в Беларуси объектами экологического аудита являются:

- хозяйственная и иная деятельность аудируемого субъекта, в процессе которой используются природные ресурсы и оказывается вредное воздействие на окружающую среду, в том числе:

17 Постановление Совета Министров Республики Беларусь от 26.05.2016 № 412 «Об утверждении положения о порядке проведения экологического аудита». 
а) состояние окружающей среды в границах зоны воздействия объектов аудируемого субъекта, в процессе деятельности которого оказывается (оказывалось) вредное воздействие на окружающую среду;

б) документация аудируемого субъекта (проектная, техническая, технологическая, эксплуатационная и другая), за исключением бухгалтерской (финансовой) отчетности;

в) иные объекты аудируемого субъекта, при проектировании, строительстве, реконструкции, вводе в эксплуатацию, эксплуатации и выводе из эксплуатации которых используются природные ресурсы и оказывается вредное воздействие на окружающую среду.

К объектам экологического аудита статья 2 Закона Украины «Об экологическом аудите» относит:

а) предприятия, учреждения и организации, их филиалы и представительства или объединения, отдельные производства, другие хозяйственные объекты;

б) системы управления окружающей природной средой;

в) другие объекты, предусмотренные законом.

Автор придерживается позиции, что проект Федерального закона «Об экологическом аудите и экологической аудиторской деятельности» следует в части определения объекта аудита расширить и включить в данное понятие:

состояние окружающей среды в границах зоны воздействия объектов аудируемого субъекта, в процессе деятельности которого оказывается (оказывалось) вредное воздействие на окружающую среду;

системы управления окружающей природной средой.

\section{6. Субъекты экологического аудита}

В настоящее время регулирующий правоотношения в сфере экологического аудита в Российской Федерации Приказ № 181 следующим образом определяет субъекты экологической аудиторской деятельности:

Экологическим аудитом имеют право заниматься физические лица, прошедшие обучение и аттестацию, и юридические лица (экологические аудиторские организации) независимо от форм собственности, получившие лицензию на осуществление данного вида деятельности.

Для аттестованных экологических аудиторов, работающих в составе имеющей лицензию организации по экологическому аудированию, наличие лицензии на данный вид деятельности не является обязательным.

Аттестация экологических аудиторов на право осуществлять экологический аудит в Российской Федерации проводится с целью обеспечения профессионального и эффективного выполнения аудиторами своих обязанностей. 
Экологические аудиторские организации могут иметь любую организационно - правовую форму в соответствии с действующим законодательством, за исключением формы открытого акционерного общества.

Для осуществления своей деятельности экологическая аудиторская организация должна иметь в своем штате не менее трех аттестованных в установленном порядке экологических аудиторов.

Экологические аудиторские организации и экологические аудиторы могут создавать объединения в форме ассоциаций или союзов для координации своей деятельности, а также представления и защиты общих имущественных интересов в соответствии с действующим законодательством. При этом непосредственная экологическая аудиторская деятельность указанных объединений не допускается.

Экологический аудит не может проводиться:

а) экологическими аудиторами, являющимися учредителями, акционерами, руководителями и иными должностными лицами аудируемого хозяйственного субъекта либо состоящими в близком родстве или свойстве (родители, супруги, братья, сестры, сыновья, дочери, а также братья, сестры, родители и дети супругов) с указанными лицами;

б) экологическими аудиторскими организациями:

в отношении субъектов хозяйственной деятельности, являющихся их учредителями, собственниками, акционерами, кредиторами, страховщиками, а также в отношении которых эти аудиторские фирмы являются учредителями, собственниками, акционерами;

в отношении субъектов хозяйственной деятельности, являющихся их дочерними предприятиями, филиалами (отделениями) и представительствами или имеющих в своем капитале долю этих аудиторских фирм.

Следует отметить, что требования, установленные действующим в настоящее время приказом Госкомэкологии РФ от 16.07.1998 № 436 «О проведении практических работ по введению экологического аудирования в Российской Федерации"для представителей профессии (экологических аудиторов), достаточно невысокие:

1) Аттестуемый экологический аудитор должен был иметь любое законченное высшее образование. При наличии не менее 5 лет практического опыта работ в области охраны окружающей среды и природопользования, к аттестации допускались физические лица, имеющие законченное среднее специальное образование или эквивалентное ему.

2) Аттестуемый экологический аудитор должен иметь стаж не менее четырех лет соответствующей практической работы в области охраны окружающей среды и природопользования.

3) Аттестация проводилась в форме заочного рассмотрения комиссией представляемых претендентом документов. 
Претендент должен был подать заявление о желании пройти аттестацию и представить документы:

- личная карточка аудитора;

- нотариально заверенные копии документов, подтверждающих имеющееся образование, научную степень (если имеется) и специальную подготовку (диплом, свидетельство об окончании специальных курсов и т.д.);

- заверенная отделом кадров или нотариально выписка из трудовой книжки, подтверждающая работу по специальности;

- свидетельство о прохождении обучения в качестве кандидата в экологические аудиторы;

- справка о прохождении практической стажировки;

- рекомендация (характеристика), выданная организацией, направившей на обучение, или организацией, где работает аудитор, или учебнометодическим центром;

- перечень печатных трудов (если имеются).

Выборочно, по решению комиссии, проводится собеседование с претендентом.

4) Экологические аудиторы должны повышать свою квалификацию путем прохождения один раз в три года курсов повышения квалификации (объем в приказе не установлен).

Программа подготовки экологических аудиторов, утвержденная Госкомэкологии РФ31.05.1999 № 01-22/24-154, и действующая до настоящего времени, включает в себя 120 часов обучения и 24 часа стажировки. Программа включает только утилитарные части, касающиеся собственно экологического наполнения аудита. Вместе с тем, в программе полностью отсутствуют разделы:

- профессиональная этика;

- аудит и стандарты аудиторской деятельности;

- правовое регулирование (как хозяйственной деятельности объектов аудита, так и экологической аудиторской деятельности).

Проект Федерального закона «Об экологическом аудите и экологической аудиторской деятельности» определяет следующий субъектный состав: экологический аудитор (экологические аудиторские организации, и индивидуальные экологические аудиторы);

аудируемое лицо;

заказчик экологического аудита.

Таким образом, экологический аудитор - это лицо, профессионально занимающееся предпринимательской деятельностью.

Обязательными требованиями к претендентам на получение квалификационного аттестата аудитора-эколога должны являться:

- наличие документа о высшем образовании установленного образца; 
- наличие стажа работы в области охраны окружающей среды, природопользования и экологической безопасности не менее трех лет.

В Экологическом кодексе Республики Казахстан установлено, что отношения между экологическими аудиторами, экологическими аудиторскими организациями и аудируемыми субъектами возникают на основе договора на проведение экологического аудита в соответствии с гражданским законодательством Республики Казахстан.

Соответственно, определяется такой важный субъект, как заказчик экологического аудита - заинтересованные юридические и физические лица, страховые организации, инвесторы, уполномоченный орган в области охраны окружающей среды, государственные органы.

Согласно законодательству Украины, юридическое лицо может осуществлять экологический аудит только при условии, что этот вид деятельности предусмотрен в его уставе, а в штате такого юридического лица имеется хотя бы один экологический аудитор. Подготовка и переподготовка экологических аудиторов могут осуществляться на базе высших учебных заведений, учреждений последипломного образования и других учебных заведений. По окончании обучения по результатам экзамена они получают соответствующий диплом или приравненный к нему документ.

\section{7. Порядок проведения экологического аудита}

Международные аудиторские стандарты предусматривают описание основных критериев, принципов и процедур, которые должны соблюдаться всеми аудиторами при осуществлении аудиторских проверок вне зависимости от условий и целей аудита. В то же время они носят рекомендательный характер и определяют профессиональные нормы и правила. В разных странах по-разному применяются и используются эти международные стандарты. В некоторых странах профессиональные аудиторские организации принимают положения международных стандартов к сведению, придерживаясь их основных положений (Канада, Великобритания, США и др.), в других - используют для разработки национальных стандартов (Австралия, Бразилия, Нидерланды). Некоторые государства применяют их в качестве собственных стандартов (Малайзия, Нигерия, Фиджи и др.).

В связи с тем, что в последнее время все больший интерес для пользователей финансовой отчетности приобретают экологические вопросы, они также нашли отражение в международных стандартах аудита «Учет экологических вопросов при аудите финансовой отчетности». В этих положениях приведен примерный перечень экологических вопросов, влияющих на финансовую отчетность. Экологические вопросы так или иначе нашли место 
и в ряде международных аудиторских стандартов ISA ${ }^{18}$ MCA № $610^{19}$ «Использование работы внутренних аудиторов» и МСА № 62020 «Использование работы эксперта аудитора» и др. Поэтому экологический аудит, опираясь и на международные стандарты, может рассматриваться как специальный вид общего аудита.

Интересный концептуальный подход к установлению связи между финансовым аудитом и экологическим аудитом изложен в одном из документов INTOSAI - Международной организации высших органов финансового контроля (Счетных палат) $)^{21}$.

В настоящее время национальных или международных стандартов (свода правил) экологической аудиторской деятельности нет. Автор полагает, что правила (стандарты) экологической аудиторской деятельности, так же как правила, действующие для финансовых аудиторов, могут подразделяться на:

- международные;

- федеральные правила (стандарты) экологической аудиторской деятельности;

- внутренние правила (стандарты) экологической аудиторской деятельности, действующие в профессиональных экологических аудиторских объединениях, а также правила (стандарты) экологической аудиторской деятельности аудиторских организаций и индивидуальных экологических аудиторов, которые разрабатываются в целях установления норм аудита, однозначно интерпретируемых всеми субъектами хозяйственной деятельности, включая арбитражный суд.

Федеральные правила (стандарты) экологической аудиторской деятельности должны содержать:

- порядок планирования и документирование экологического аудита;

- форму, содержание и порядок представления экологического аудиторского заключения.

${ }^{18}$ Handbook of International Quality Control Auditing, Review, Other Assurance, and Related Services Pronouncements.2018 Edition.Volume 1. - International Auditing and Assurance Standard Board.: NY. - 2018. - 1146 c.

${ }^{19}$ Приказ Минфина России от 09.01.2019 № 2н «О введении в действие международных стандартов аудита на территории Российской Федерации и о признании утратившими силу некоторых приказов Министерства финансов Российской Федерации».

${ }^{20}$ Приказ Минфина России от 09.01.2019 № 2н «О введении в действие международных стандартов аудита на территории Российской Федерации и опризнании утратившими силу некоторых приказов Министерства финансов Российской Федерации».

${ }^{21} Э$ кологический аудит в контексте финансового аудита и аудита соответствия. ИНТОСАИ - ИССАИ 5120. - 2016. 
Подробно порядок проведения экологического аудита был описан в отмененном в настоящее время ГОСТ Р ИСО 14010-98. Автор полагает, что несмотря на то, что ГОСТ Р ИСО 14010-98 отменен, им можно пользоваться в целях систематизации работы.

Для начала работ по проведению экологической аудиторской проверки для определения стоимости работ необходимо определить область и объем экологического аудита.

Сбор и анализ данных об аудируемой организации:

- местоположение и тип промышленных объектов (площадочный, линейный и т.д.), входящих в состав организации;

- организационно-штатная структура административного управления (наличие филиалов, обособленных структурных подразделений и т.д.);

- вид основной деятельности (производство и передача электроэнергии, оперативно-диспетчерское управление, ремонт, сервис и т.д.), общие технологические схемы, включая оборудование и промышленные средства;

- состав и технологические процессы вспомогательных систем, обеспечивающих жизнедеятельность организации;

- организация деятельности в области природопользования, охраны окружающей среды, обеспечения техногенной, энергетической и экологической безопасности, защиты от чрезвычайных ситуаций;

- состояние техногенной обстановки и окружающей среды на близлежащей территории.

Объем экологического аудита - это совокупность взаимоувязанных аудиторских процедур, документированных правилами, стандартами экологической аудиторской деятельности, применение которых обязательно в соответствии с планом и программой аудита для сбора аудиторских доказательств и подготовки экологического аудиторского отчета и экологического аудиторского заключения и для достижения цели экологического аудита в конкретных условиях его проведения.

Методология проведения экологического аудита основана на:

- представлении аудируемой организации как «продукционной систеMы»;

- использовании «процессного подхода» к анализу деятельности аудируемой организации путем анализа основных производственных технологических процессов и технологических процессов обеспечения жизнедеятельности предприятия (водо-, тепло-, энергоснабжения, молниезащиты, электрохимзащиты и т.д.), выполняемых с использованием соответствующего оборудования, средств, устройств и т.д. и оказывающих воздействие на окружающую среду;

- использовании результатов инвентаризации воздействия на окружающую среду и источников воздействия со стороны окружающей среды на персонал, сырье, производственные процессы, оборудование и т.д.; 
- использование результатов производственного контроля (экологического; земельного; обращения с отходами; состояния атмосферного воздуха и водных объектов и т.д.);

- использование результатов государственного экологического контроля, актов, заключений и предписаний надзорных органов.

Для проведения аудита формируется аудиторская группа с учетом компетентности аудиторов, необходимой для достижения целей аудита. Если аудит проводит один аудитор, он должен выполнять обязанности руководителя аудиторской группы.

Экологическая аудиторская группа может состоять из следующих лиц:

- руководитель экологической аудиторской группы - аудитор-эколог, имеющий дополнительные знания и навыки по руководству аудитом для его результативного и эффективного проведения и подготовленный к выполнению процедур аудита;

- аудитор-эколог - лицо, обладающее компетентностью для проведения аудита;

- технический эксперт - лицо, предоставляющее аудиторской группе свои знания по специальным вопросам, которые могут возникнуть в процессе проверки;

- наблюдатель (при необходимости) - представитель проверяемой организации (или вышестоящей организации), свидетельствующий соответствие процедур аудита руководящим указаниям по аудиту;

- аудитор-стажер - лицо, прошедшее требуемую теоретическую подготовку по специальной образовательной программе и приобретающий необходимый практический опыт под руководством руководителя аудиторской группы;

- сопровождающие лица - специалисты, назначенные проверяемой организацией, оказывающие помощь аудиторской группе: обеспечивать контакты и время для бесед, свидетельствовать в ходе аудита от имени проверяемой организации; предоставлять разъяснения при сборе информации, а также обеспечивать соблюдение членами аудиторской группы правил по безопасности.

При формировании аудиторской группы необходимо учитывать:

а) вид, цели, область, объем, критерии и предполагаемую продолжительность аудита;

б) необходимость обеспечения независимости аудиторской группы от проверяемой организации;

в) возможности для сотрудничества с персоналом проверяемой организации;

г) понимание специфики деятельности и прежний опыт организации.

Заказчик имеет право требовать замены аудиторов по объективным причинам (аудитор ранее работал в проверяемой организации или же ока- 
зывал ей услуги по консалтингу; предыдущее неэтичное поведение аудитора и т.д.).

Состав аудиторской группы и назначение ее руководителя закрепляются приказом руководителя экологической аудиторской организации.

Экологическая аудиторская организация и индивидуальный аудиторэколог обязаны планировать свою работу так, чтобы проверка была проведена эффективно.

Планирование экологического аудита предполагает формулировку его цели, конкретизацию области, объема, методологического обеспечения, критериев, последовательности проведения для того, чтобы он был выполнен с минимальными затратами, качественно и своевременно. Планирование позволяет эффективно распределять работу между аудиторами.

Затраты времени на планирование зависят от масштабов деятельности аудируемой организации, сложности аудита, опыта работы аудиторов с организациями, ранее проверяемыми аудиторами, а также знания ими специфики ее деятельности.

Руководитель аудиторской группы (аудитор) вправе обсуждать план аудита с руководством аудируемой организации для повышения эффективности аудита и координации выполнения аудиторских процедур с работой персонала.

Ответственность за качество и своевременность разработки плана несет руководитель аудиторской группы.

Получение предварительной информации о деятельности аудируемой организации является важной частью планирования работы, помогает аудитору выявить факторы, которые могут оказывать существенное влияние на документацию организации и на формирование его суждения о соответствии ее деятельности законодательству.

План аудита должен быть достаточным для разработки программы и планов-графиков аудита.

При разработке плана рекомендуется принимать во внимание предварительно полученную информацию о следующих факторах:

а) экономические факторы и условия в отрасли (корпоративном объединении), специфику деятельности, финансовое состояние; структура управления деятельностью организации;

б) возможность (в том числе по опыту ранее проведенных аудитов) существенных искажений или недобросовестных действий персонала организации;

в) уровень компьютеризации системы документооборота и ее особенностей;

г) возможность и целесообразность привлечения других аудиторских организаций к проверке филиалов, подразделений, дочерних компаний аудируемой организации; 
д) возможность и целесообразность привлечения технических экспертов в связи с уникальностью и сложностью технологических процессов и оборудования производства;

е) возможность и целесообразность оказания аудируемой организации сопутствующих экологическому аудиту услуг.

План аудита утверждается заказчиком, подписывается руководителем аудиторской группы.

В случае, если аудируемая организация не является заказчиком аудита, план также согласовывается с ее руководителем.

Руководителю аудиторской группы (аудитору) необходимо составить и документально оформить программу аудита, конкретизирующую план проведения аудита.

Программа аудита является основой для выбора процедур аудита, а также средством проверки надлежащего выполнения аудита.

В процессе подготовки программы аудитор обязан принимать во внимание:

требования законодательства в области производственной деятельности организации природопользования, охраны окружающей среды, обеспечения техногенной, энергетической и экологической безопасности и защиты от ЧС;

требуемый уровень уверенности, который должен быть обеспечен при процедурах проверки;

временные рамки выполнения процедур проверки;

необходимость координации взаимодействия с персоналом аудируемой организации;

целесообразность привлечения технических экспертов;

специфику условий деятельности организации.

План аудита и программа аудита конкретизируются планом-графиком аудита и при необходимости уточняются в ходе аудита.

Планирование аудитором собственной работы осуществляется с учетом обстоятельств или неожиданных результатов, полученных в ходе выполнения аудиторских процедур.

Причины внесения значительных изменений в план и программу аудита должны быть документально зафиксированы.

Содержание аудита:

определяется многофункциональностью и масштабностью деятельности проверяемой организации, количеством аудируемых подразделений, требованиями к их природоохранной деятельности, природопользованию, обеспечению безопасности и защиты от чрезвычайных ситуаций с учетом состояния экологической обстановки в регионах; наличием особо охраняемых природных объектов, памятников культурного наследия, ограничений на промышленно-хозяйственную деятельность в местах проживания ма- 
лочисленных народов Севера, Сибири и Дальнего Востока Российской Федерации;

зависит от частоты аудитов, заключений по результатам предыдущих аудитов, существенных изменений видов деятельности организации, мнения заинтересованных сторон, в частности, граждан и их объединений, высказанных в ходе общественных обсуждений (слушаний, сходов, местных референдумов и т.д.).

Критерии экологического аудита - совокупность требований, закрепленных нормативными правовыми актами и стандартами в области природопользования, охраны окружающей среды, техногенной, энергетической и экологической безопасности, защиты от чрезвычайной ситуации природного и техногенного характера, устойчивого развития, а также принятых организацией экологически ориентированных обязательств, декларируемых ею в экологической политике.

При подготовке предложений по ресурсам для обеспечения проведения аудита руководство организации учитывает:

цели, объем и область аудита;

требуемые финансовые ресурсы для проведения аудита;

степень разработки методов проведения аудитов;

наличие аудиторов-экологов из числа специалистов организации, имеющих сертификаты на право проведения внутренних аудитов и обладающих необходимой компетентностью;

возможности привлечения технических экспертов;

степень подготовленности персонала к проведению аудита;

время на переезд аудиторов, их обустройство и необходимые условия обеспечения их деятельности.

Внедрение программы экологического аудита состоит в следующем:

подготовка проекта распоряжения руководства проверяемой организации о сроках проведения, цели, объеме и области аудита, предполагаемом руководителе и составе аудиторской группы;

рассылка копий плана, программы, планов-графиков, рекомендованных перечней критериев и документации, представляемой аудируемыми подразделениями;

установление сроков подготовки организации к проведению планового аудита;

подготовка необходимых ресурсов для проведения аудита.

Ответственность за управление программой аудита возлагается на:

представителя высшего руководства организации - за несвоевременное утверждение программы, не обеспеченность необходимыми ресурсами (финансовыми, техническими, кадровыми и т.д.);

аудиторов - за некачественное выполнение ими процедур аудита вследствие недостаточности записей для подготовки обоснованных отчета и экологического аудиторского заключения; 
руководителя аудиторской группы - за отсутствие надлежащего руководства аудиторской группой и недостаточную обоснованность выводов по результатам аудита;

персонала аудируемой организации - за несвоевременное представление и недостоверность документации о деятельности организации в области природопользования, охраны окружающей среды, обеспечения техногенной и экологической безопасности и защиты от чрезвычайных ситуаций;

наблюдателя - за «невскрытие» отступлений участников аудита от установленных процедур аудита, программы, плана;

технических экспертов - за недостаточно обоснованные заключения по специальным вопросам, возникающим в ходе аудита;

сопровождающих лиц - за необеспеченность аудиторской группы необходимыми условиями для проведения аудита (контактов с персоналом, посещения рабочих мест, оказания помощи при сборе информации).

При проведении внешнего аудита первоначальный контакт с организацией устанавливает руководитель аудиторской группы в процессе вводного (вступительного) совещания с руководством организации.

Вводное совещание проводит руководитель экологической аудиторской группы.

Цель вводного (вступительного) совещания:

подтверждение полномочий проведения экологического аудита;

определение правил обеспечения безопасности аудиторами при посещении производственных подразделений;

определение каналов обмена информации и объема информации, которую следует сообщать руководству аудируемой организации, включая:

а) организационно-методический подход аудитора к проведению аудита; обеспокоенность аудитора по поводу любых ограничений объема аудита, комментарии по поводу уместности любых дополнительных требований руководства аудируемой организации;

б) выбор или изменение руководством аудируемой организации технологических операций, состава оборудования и т.д., которые могут оказать существенное влияние на соответствие деятельности организации законодательству;

в) возможное влияние на документацию и отчетность аудируемой организации каких-либо значимых рисков и внешних факторов, (например, судебных разбирательств);

г) существенные неопределенности, касающиеся событий или условий, которые могут в значительной мере поставить под сомнение способность аудируемой организации обеспечить соответствие деятельности требованиям законодательства; 
д) разногласия аудитора с руководством аудируемых подразделений по вопросам, которые по отдельности или в совокупности могут являться значимыми для аудиторского заключения. Сообщаемая в этой связи информация должна включать пояснения важности этого вопроса и сведения о том, был ли данный вопрос разрешен или нет;

е) предполагаемые модификации аудиторского заключения;

установление порядка доступа к информации, в том числе, содержащей сведения конфиденциального характера;

согласование присутствия наблюдателей и сопровождающих;

согласование критериев принятия решения о значимости выявленных отклонений, об оценке эффективности аудита, о форме заключения по результатам аудита;

определение регулярности и целесообразности встреч руководства с экологической аудиторской группой;

согласование даты заключительного совещания.

Цель анализа: подтвердить наличие документации, необходимой для проведения аудита, оценить ее полноту, достоверность и правильность оформления.

Анализ документации проводится в соответствии с учетом вида и масштаба деятельности организации (подразделения), целей и области аудита, отчетов по предыдущим аудитам.

Результаты анализа документации могут быть представлены в виде раздела отчета.

Если документация признана неадекватной требованиям по ее содержанию и оформлению, то руководитель аудиторской группы информирует об этом представителя высшего руководства организации.

Принимается решение о продолжении экологического аудита или о приостановлении его до устранения выявленных отклонений (несоответствий).

Подготовка состоит:

в корректировке планов-графиков аудита с руководителями аудируемых подразделений;

в уточнении разграничения ответственности аудиторов за аудит подразделений, технологических участков или технологических процессов;

в подготовке рабочих документов для регистрации материалов аудита. Использование ранее подготовленных рабочих документов не должно ограничивать объем проверок, которые могут быть скорректированы по результатам анализа собранных во время аудита данных.

Основные элементы аудита:

- предварительное совещание с руководством проверяемого подразделения в целях: обсуждения и подтверждения скорректированного плана-графика аудита; времени проведения опросов; ознакомления с методами и процедурами аудита, включая классификацию отклонений (несоот- 
ветствий); информирования о порядке рассмотрения апелляций по процедурам проведения аудита или выводов по его результатам;

- в случаях проведения анализа документации и экспертизы документации на месте без длительного перерыва между ними допустимо не проводить предварительного совещания с руководством подразделений при условии, что соответствующие вопросы обсуждены в процессе вводного совещания;

- обмен информацией в ходе аудита (относительно рисков, связанных с безопасностью и охраной окружающей среды, о выходе из области аудита, об обстоятельствах, затрудняющих проведение аудита, о невыполнимости плана аудита и т.д.) в целях корректировки плана аудита или прекращения аудита;

- уточнение роли и обязанностей сопровождающих лиц, наблюдателей и технических экспертов;

- сбор и верификация информации в соответствии с планом-графиком и анализ соответствия показателей деятельности подразделения критериям экологического аудита, подтверждаемого представленной документацией.

В целях обоснованности результатов экологического аудита аудитор обязан иметь достаточно представительные свидетельства экологического аудита - ссылки на информацию, содержащуюся в документации организации, характеризующую ее деятельность в перечисленных выше областях и имеющую отношение к критериям аудита.

Аудитор должен документально оформлять записи, которые важны с точки зрения предоставления доказательств, подтверждающих аудиторское мнение, а также доказательств того, что аудиторская проверка проводилась в соответствии с федеральными правилами (стандартами) аудиторской деятельности и корпоративным стандартом.

Под документацией понимаются рабочие документы и материалы, подготавливаемые аудитором и для аудитора, получаемые и хранимые аудитором на бумаге, фотопленке, в электронном виде или в другой форме.

Документация экологической аудиторской группы должна содержать:

- план аудита;

- программу аудита;

- план-график аудита;

- результаты проверки документации и отчетности аудируемой организации (рабочие записи аудитора);

- протоколы выявленных отклонений (несоответствий);

- статус мероприятий по устранению отклонений (срочность их выполнения);

- протоколы вводного и заключительного совещания аудиторской группы с руководством аудируемых подразделений. 
Рабочие записи используются аудитором:

- при осуществлении текущего контроля выполненной работы (итоги которой обычно подводятся в конце рабочего дня на совещании аудиторов);

- для фиксирования аудиторских доказательств, подтверждающих выводы аудитора.

Аудитор должен составлять рабочую документацию в форме и объеме, необходимых и достаточных для понимания выполненных им аудиторских процедур, их результатов и сделанных выводов.

В случаях, когда аудитор оценивал сложные принципиально важные вопросы деятельности или высказывал по ним профессиональное суждение, в рабочую документацию следует включать факты, которые были известны аудитору на момент формулирования выводов, и необходимую аргументацию.

Аудитор вправе определять состав и объем документации, руководствуясь своим профессиональным мнением. Вместе с тем объем документации должен быть таков, чтобы в случае передачи работы другому аудитору он смог бы исключительно на основе данной документации (не прибегая к дополнительным беседам или переписке с прежним аудитором) понять результаты проделанной работы и обоснованность решений и выводов прежнего аудитора.

Допускается использовать графики, аналитическую и иную документацию, подготовленные аудируемой организацией. В этих случаях аудитор обязан убедиться в том, что такие материалы оформлены надлежащим образом.

Рабочие документы обычно содержат:

- информацию, касающуюся организационно правовой формы деятельности и административной структуры аудируемой организации;

- копии юридических документов, соглашений и протоколов или извлечения из них;

- информацию об отрасли, экономической и правовой среде, в которой аудируемая организация осуществляет свою деятельность;

- информацию, отражающую процесс корректировки плана-графика аудита;

- доказательства понимания аудитором документации государственной статистической отчетности и результатов производственного экологического контроля;

- иллюстрацию наиболее важных экологических показателей деятельности организации и тенденций их изменения;

- сведения о характере, временных рамках, объеме ранее проведенных аудиторских процедур и результатах их выполнения;

- копии сообщений, направленных другим аудиторам, техническим экспертам и третьим лицам, и полученных от них ответы; 
- копии писем и телеграмм по вопросам аудита, доведенных до сведения руководителей аудируемой организации или обсуждавшихся с ними, выявленные существенные отклонения, письменные заявления, полученные от аудируемой организации;

- выводы, сделанные аудитором по наиболее важным вопросам аудита, включая ошибки и необычные обстоятельства, которые были выявлены аудитором в ходе аудита, и сведения -о действиях, предпринятых им в связи с этим;

- отклонения (несоответствия) и подтверждающие их свидетельства аудита, классифицированные и ранжированные, проанализированные руководителем аудиторской группы и руководителем аудируемого подразделения для подтверждения объективности свидетельств аудита.

Рабочие документы должны быть составлены и систематизированы таким образом, чтобы соответствовать целям аудиторской проверки и потребностям аудитора в ходе ее проведения. Рекомендуется использовать разработанные аудиторской организацией типовые формы документации (например, стандартную структуру аудиторского файла (папки) рабочих документов, бланки, вопросники, типовые письма и обращения, отчета, заключения, протоколов, совещаний и т.д.).

В случае проведения аудиторских проверок в течение ряда лет некоторые файлы рабочих документов (папки) могут быть отнесены к категории постоянных, обновляемых по мере поступления новой информации.

Рабочие документы являются собственностью аудитора.

Они могут быть предоставлены аудируемой организации по усмотрению аудитора, но не должны служить заменой каких-либо записей и документации аудируемой организации.

После подготовки экологического аудиторского отчета и экологического аудиторского заключения (завершения экологического аудита) и при отсутствии каких-либо разногласий по форме принятого экологического аудиторского заключения рабочие документы передаются экологической аудиторской организации для проведения технического контроля (при необходимости) и уничтожения в надлежащем порядке.

Выводы экологического аудита - это результаты анализа собранных свидетельств аудита в целях формирования заключения экологического аудита о соответствии деятельности аудируемой организации законодательству, положениям, стандартам в области аудита.

Выводы аудита:

a) указывают на соответствие (или несоответствие) критериям аудита;

б) должны определять направления улучшения деятельности проверяемой организации.

Предложения по улучшению деятельности организации формируются с учетом выявленных отклонений и потенциала для улучшения деятельности. 
В процессе аудита возможны следующие ситуации:

а) отклонений не выявлено;

б) отклонений не выявлено, но имеется потенциал для улучшения экологически ориентированной деятельности организации (подразделения);

в) выявлено отклонение, классифицируемое как несущественное (которое может быть устранено в ходе аудита);

г) выявлено отклонение, классифицируемое как существенное.

Отклонения, требующие для их устранения дополнительных ресурсов, могут рассматриваться как основа для разработки мероприятий, включаемых персоналом аудируемой организации в плановые документы (по модернизации основных технических средств, внедрению новейших технологий, разработки очистных сооружений и т.д.).

В целях выполнения мероприятий может быть рекомендовано включение в краткосрочные планы, предусматривающие необходимое финансирование работ.

В качестве направления улучшения деятельности организации может быть рекомендовано оказание сопутствующих экологическому аудиту услуг. Однако хозяйственное решение по реализации выданных рекомендаций принимает руководство аудируемой организации.

До завершения аудита по вопросам, существенным для аудиторских выводов (в случае невозможности получения достаточных аудиторских доказательств другим путем), аудитор должен получить надлежащие заявления и разъяснения руководства аудируемой организации:

о признании им своей ответственности за достоверность документации и отчетности;

официальные заявления в письменной форме или заверенную соответствующими подписями документацию и отчетность;

решения органа, осуществляющего руководство деятельностью аудируемой организации.

Аудитор должен:

а) получить аудиторские доказательства, подтверждающие данные заявления и разьяснения руководства, используя внутренние или внешние по отношению к аудируемой организации источники информации;

б) оценить, являются ли заявления и разъяснения руководства достаточными и соответствуют ли они остальным аудиторским доказательствам, в том числе заявлениям и разъяснениям руководства по аналогичным вопросам;

в) определить компетентность и степень информированности лиц, предоставивших заявления и разъяснения.

Заявления и разъяснения руководства, как правило, не могут заменить другие аудиторские доказательства, доступные аудитору. Если аудитор не может получить достаточные надлежащие аудиторские доказательства по 
существенному вопросу, помимо таких доказательств, как заявления и разъяснения руководства, и можно ожидать, что такие доказательства существуют, то данную ситуацию надлежит рассматривать как ограничение области аудита.

В определенных случаях заявления и разъяснения руководства могут оказаться единственными существующими аудиторскими доказательствами (например, касающиеся не оформленных документально планов и намерений руководства).

Если заявления и разъяснения руководства противоречат другим аудиторским доказательствам, аудитор должен исследовать причины расхождений и в случае необходимости критически оценить надежность заявлений и разъяснений руководства по аналогичным или другим вопросам.

Аудитор, как правило, включает в свои рабочие документы доказательства, подтверждающие факт получения им заявлений и разъяснений от руководства, в форме:

краткого изложения бесед с руководством или материалов, предоставленных руководством в письменной форме;

писем-представлений руководства;

подготовленного аудитором письма, в котором излагается понимание аудитором позиции руководства по определенному кругу вопросов, которое затем официально подтверждается руководством;

документов, подтверждающих результаты деятельности аудируемой организации (например, экземпляра отчетности, подписанного руководством).

Запрашивая у руководства письмо-представление, аудитор должен потребовать, чтобы оно было адресовано аудитору, датировано, подписано теми руководителями, которые несут ответственность за деятельность организации (в частности, генеральным директором, главным инженером или техническим директором, руководителем проверяемого подразделения).

Отказ руководства представить заявления и разъяснения, которые аудитор считает необходимыми, считается ограничением области аудита. В указанном случае аудитор должен выразить мнение с оговоркой или отказаться от выражения мнения, критически оценить надежность и достоверность других заявлений и разъяснений руководства в ходе аудита, а также проанализировать, может ли отказ в представлении заявлений и разъяснений оказать влияние на аудиторское заключение.

По окончанию работы проводится заключительное совещание. Целью заключительного совещания является представление предварительных выводов и экологического аудиторского заключения, направлений улучшения деятельности организации таким образом, чтобы они были однозначно поняты участниками совещания, а также фиксация выполнения экологического аудита в полном соответствии с программой. 
Участниками совещания являются представители высшего руководства организации, руководители подразделений, экологическая аудиторская группа и другие стороны (наблюдатели, аудиторы-стажеры, технические эксперты).

Председателем совещания является руководитель экологической аудиторской группы, что подчеркивает независимость аудиторов.

Совещание должно оформляться протоколом, содержащим список присутствующих с указанием их должностей.

\section{8. Результаты проведения экологического аудита}

Результатом проведения экологического аудита является подготовка для аудируемой организации отчета и заключения.

В настоящее время регулирующий правоотношения в сфере экологического аудита в Российской Федерации Приказ № 181 устанавливает содержание заключения по экологическому аудиту:

Заключение должно состоять из трех частей - вводной, аналитической и итоговой.

В вводной части указывается юридический адрес, расчетный счет и телефоны экологической аудиторской организации, фамилии, имена и отчества всех экологических аудиторов, принимавших участие в проверке, порядковый номер, дата выдачи и наименование органа, выдавшего лицензию на осуществление экологического аудита, срок ее действия, а также срок проведения экологического аудита.

В аналитической части указываются:

наименование субъекта хозяйственной деятельности, период его деятельности, за который проводится экологический аудит;

результаты анализа природоохранной деятельности, соответствие ее экологическим требованиям;

факты выявленных в ходе проверки существенных нарушений природоохранительного законодательства Российской Федерации, которые нанесли или могут нанести ущерб окружающей природной среде и здоровью населения.

Итоговая часть содержит:

обоснованные выводы о воздействии субъекта хозяйственной деятельности на состояние окружающей среды;

конкретные и приемлемые меры по снижению негативного воздействия на окружающую среду;

последствия непринятия субъектом хозяйственной деятельности соответствующих мер.

Проект Федерального закона «Об экологическом аудите и экологической аудиторской деятельности» определяет, что по результатам про- 
ведения экологического аудита составляется заключение экологического аудита.

Заключение экологического аудита должно содержать:

1) наименование «Заключение экологического аудита»;

2) указание на вид экологического аудита (обязательный, добровольный комплексный, добровольный технологический) и случай его проведения (для обязательного экологического аудита);

3) дату начала и окончания проведения экологического аудита;

4) сведения об аудируемом лице: наименование, основной государственный регистрационный номер, организационно-правовую форму, адрес (место нахождения) юридического лица или фамилию, имя, отчество (при наличии), место жительства, дату государственной регистрации индивидуального предпринимателя;

5) сведения об экологической аудиторской организации, индивидуальном экологическом аудиторе, экологическом аудиторе, участвующих в проведении экологического аудита: наименование организации, фамилия, имя, отчество индивидуального экологического аудитора, экологического аудитора, государственный регистрационный номер, место нахождения, регистрационный номер лицензии на осуществление экологической аудиторской деятельности, номера квалификационных аттестатов экологических аудиторов, участвовавших в проведении экологического аудита;

6) описание объектов экологического аудита, в том числе код объекта, оказывающего негативное воздействие на окружающую среду, сведения о его фактическом месте нахождения и категории;

7) сведения о составе и объеме работ, выполненных экологической аудиторской организацией, индивидуальным экологическим аудитором для выражения мнения о соответствии объектов экологического аудита требованиям в области охраны окружающей среды;

8) описание выявленных несоответствий соблюдения юридическим лицом или индивидуальным предпринимателем требований, в том числе нормативам и нормативным документам, федеральным нормам и правилам, в области охраны окружающей среды (при наличии);

9) мнение экологической аудиторской организации, индивидуального экологического аудитора о соответствии (либо - несоответствии) объекта экологического аудита требованиям в области охраны окружающей среды;

10) личные подписи экологических аудиторов, участвовавших в проведении экологического аудита;

11) дату утверждения заключения экологического аудита.

ГОСТ Р ИСО 14010-98 дает более развернутые рекомендации по составлению отчета и заключения по проведенному экологическому аудиту: 
Отчет об аудите составляет руководитель экологической аудиторской группы (с участием аудиторов), который несет ответственность за полноту, достоверность и доступность для понимания отчета.

Отчет должен быть подписан всеми аудиторами и утвержден руководителем экологической аудиторской организации.

Срок подготовки отчета определяется в зависимости от объема аудита заказчиком и руководителем аудиторской организации.

Экологическое аудиторское заключение: официальный документ, разрабатываемый по результатам экологической аудиторской проверки, составленный в соответствии с федеральными правилами (стандартами) аудиторской деятельности и содержащий выраженное в установленной форме мнение экологической аудиторской организации или индивидуального аудитора-эколога о соответствии деятельности проверяемой организации в области использования природных ресурсов и охраны окружающей среды, техногенной, энергетической и экологической безопасности, защиты от ЧС природного и техногенного характера требованиям законодательства, правилам, инструкциям и стандартам, а также о достоверности ее государственной статистической отчетности в указанных областях деятельности.

Экологическое аудиторское заключение имеет следующую структуру:

а) название: Экологическое аудиторское заключение о деятельности организации;

б) сведения об аудируемой организации и адресате (собственник аудируемой организации, акционеры, совет директоров и т.д.);

в) сведения об экологической аудиторской организации (индивидуальном аудиторе) с указанием членства в профессиональном объединении аудиторов-экологов;

г) введение;

д) область и объем аудита;

е) мнение аудиторов, представленное в одной из установленных федеральными правилами (стандартами) форм - положительное; модифицированное; отрицательное;

ж) дата аудиторского заключения;

з) подписи аудиторов.

Необходимо соблюдать единство формы и содержания аудиторского заключения, чтобы облегчить его понимание пользователем и помочь обнаружить необычные обстоятельства в случае их появления.

Экологическое аудиторское заключение должно:

- содержать краткий перечень проверенной отчетности аудируемой организации с указанием отчетного периода;

- включать заявления о том, что ответственность за ведение отчетности и ее достоверность возложена на аудируемую организацию, ответственность аудитора заключается только в выражении мнения о соответствии 
деятельности аудируемой организации и порядка ведения государственной статистической отчетности законодательству;

- описывать область, объем аудита с указанием, что аудит был проведен в соответствии с федеральными законами, федеральными правилами (стандартами) аудиторской деятельности, внутренними правилами (стандартами) аудиторской деятельности, действующими в профессиональных аудиторских объединениях, членом которых является аудитор, либо стандартом корпоративного объединения, в состав которого входит аудируемая организация;

- содержать заявление о том, что аудит был проведен на выборочной основе с целью обеспечения разумной уверенности аудиторов в том, что представленная документация и отчетность не содержат существенных искажений;

- содержать заявление аудитора относительно того, что аудит предоставляет достаточные основания для выражения мнения о достоверности документации и отчетности во всех существенных отношениях.

Для выражения аудиторского мнения используются слова: «По нашему мнению, документация и отчетность организации отражают достоверно ее деятельность в области природопользования, охраны окружающей среды, обеспечения техногенной, энергетической и экологической безопасности, защиты от ЧС».

Аудитор должен датировать аудиторское заключение числом, когда был выполнен план аудита. Данное обстоятельство предоставляет пользователю основания полагать, что аудитор учел влияние, которое оказали на документацию, отчетность и экологическое аудиторское заключение события и операции, известные аудитору, и возникшие до этой даты.

Аудиторское заключение должно быть утверждено руководителем экологической аудиторской организации или уполномоченным им лицом. Подписи должны быть скреплены печатью. В случае если аудит осуществлялся индивидуальным аудитором, аудиторское заключение должно быть подписано только аудитором.

Аудиторское заключение готовится в количестве экземпляров, согласованном экологической аудиторской организацией (аудитором) и аудируемой организацией, но и экологическая аудиторская организация и аудируемая организация должны получить не меньше чем по одному экземпляру аудиторского заключения.

В соответствии с федеральными правилами (стандартами) аудиторской деятельности мнения аудиторов о соответствии деятельности аудируемой организации, ее документации и отчетности законодательству представляется в одной из следующих форм:

- безоговорочно положительное мнение, если экологическая аудиторская группа аудитор приходит к заключению о том, что документация и от- 
четность дают достоверное представление о деятельности аудируемой организации в области природопользования, охраны окружающей среды, обеспечения техногенной, энергетической и экологической безопасности, защиты От ЧС;

- модифицированное аудиторское заключение, если возникли факторы:

не влияющие на аудиторское мнение, но описываемые в аудиторском заключении с целью привлечения внимания пользователей к какой-либо ситуации, сложившейся у аудируемой организации и раскрытой в документации и отчетности;

влияющие на аудиторское мнение, которые могут привести к мнению с оговоркой, отказу от выражения мнения или отрицательному мнению.

Аудиторское заключение может быть модифицировано посредством включения части, привлекающей внимание к ситуации, влияющей на документированную отчетность, но рассмотренной в пояснениях к отчетности.

Часть, не влияющая на аудиторское мнение, обычно включается после части с выражением мнения и содержит указание на то, что данная ситуация не является основанием для включения оговорки в аудиторское мнение.

Аудитор не в праве выразить безоговорочно положительное мнение, если существует хотя бы одно из следующих обстоятельств:

a) ограничен объем работы аудитора;

б) имеется разногласие с руководством относительно:

допустимости осуществляемой деятельности, способов и приемов ее проведения;

адекватности раскрытия информации в документации и отчетности.

Обстоятельства, указанные в подпункте «а», могут привести к выражению мнения с оговоркой или к отказу от выражения мнения.

Обстоятельства, указанные в подпункте «б», могут привести к выражению мнения с оговоркой или к отрицательному мнению.

Мнение с оговоркой должно быть выражено, если аудитор приходит к выводу о том, что невозможно выразить безоговорочно положительное мнение, но влияние разногласий с руководством или ограничение объема аудита не настолько существенно и глубоко, чтобы выразить отрицательное мнение или отказаться от выражения мнения. Мнение с оговоркой должно содержать формулировку: «за исключением влияния обстоятельств...» (указать обстоятельства, к которым относится оговорка).

Отказ от выражения мнения имеет место, когда ограничение области и объема аудита настолько существенно и глубоко, что аудитор не может получить достаточные доказательства и, следовательно, не в состоянии выразить мнение о достоверности документации и отчетности.

Отрицательное мнение следует выражать только тогда, когда наличие какого-либо разногласия с руководством настолько существенно для до- 
кументации и отчетности, что аудитор приходит к выводу, что внесение оговорки в аудиторское заключение не является адекватным для того, чтобы раскрыть вводящий в заблуждение или неполный характер документации и отчетности.

Если аудитор выражает любое мнение, кроме безоговорочно положительного, он должен четко описать все причины этого в аудиторском заключении. Как правило, эта информация излагается в отдельной части, предшествующей части с выражением мнения или с отказом от выражения мнения, и может включать ссылку на более подробную информацию (при ее наличии) в пояснениях к документации или отчетности.

Аудит завершается рассылкой отчета и экологического аудиторского заключения и представлением информации, полученной по результатам экологического аудита, руководству аудируемой организации и представителям ее собственника.

Информация представляет собой сведения, которые, по мнению аудитора, являются одновременно важными для руководства и представителей собственника аудируемой организации.

Руководством аудируемого организации являются лица, отвечающие за повседневное руководство ею, а также осуществление производственнохозяйственных операций, ведение государственной статистической отчетности (например, генеральный директор, технический директор, главный инженер и т.д.).

Представителями собственника являются лица или коллегиальные органы, которые осуществляют общий надзор и стратегическое руководство деятельностью аудируемой организации, а также в соответствии с учредительными документами могут контролировать текущую деятельность ее руководства, в том числе назначать или освобождать от должности соответствующих лиц из состава руководства.

Организационная структура и принципы корпоративного управления могут быть различными для проверяемых организаций. Это усложняет задачу по универсальному определению круга лиц, которым аудитор сообщает информацию, представляющую интерес для управления аудируемой организацией. Аудитор основывается на собственном профессиональном суждении для определения тех лиц, которым должна сообщаться информация, принимая во внимание управленческую структуру аудируемой организации, обстоятельства аудиторского задания и особенности законодательства, учитывая права и обязанности соответствующих лиц.

В договоре о проведении экологического аудита (оказании сопутствующих услуг) может быть разъяснено, что аудитор будет сообщать информацию, представляющую интерес для управления, на которую он обратит внимание в результате аудита, и что он не обязан разрабатывать процедуры, специально направленные на поиск информации, имеющей значение для 
управления аудируемой организацией, а также могут быть указаны форма, в которой будет сообщаться информация, надлежащие получатели информации, другие вопросы, заслуживающие внимания представителей собственника (например, существенные недочеты в области производственного экологического контроля, вопросы, касающиеся порядочности руководства аудируемой организации, а также случаи недобросовестных действий руководства).

Взаимоотношения между аудитором и руководством организации или представителями собственника аудируемой организации должны основываться на требованиях профессиональной этики, независимости и объективности аудиторов.

Аудитор может сообщать надлежащим получателям информацию в устной или письменной форме.

Если информация сообщается в устной форме, аудитору следует документально отразить ее в рабочих документах.

Если аудитор считает, что необходимо модифицировать аудиторское заключение, то любая иная письменная информация, направляемая аудитором руководству или представителям собственника аудируемой организации, не может рассматриваться в качестве надлежащей замены модифицированного аудиторского заключения.

Аудитор должен проанализировать, может ли какая-либо информация, полученная по результатам предыдущего аудита, иметь значение для достоверности документации и отчетности текущего года. Если аудитор приходит к выводу, что такая информация представляет интерес для управления аудируемой организацией, он может принять решение повторно сообщить ее представителям собственника аудируемой организации.

Требования к составлению, содержанию и оформлению заключения экологического аудита устанавливаются уполномоченным Правительством Российской Федерации федеральным органом исполнительной власти.

Заключение экологического аудита утверждается руководителем экологической аудиторской организации, индивидуальным экологическим аудитором.

Заключение экологического аудита представляется экологической аудиторской организацией или индивидуальным экологическим аудитором заказчику экологического аудита.

Дача заведомо ложного заключения экологического аудита влечет административную и уголовную ответственность.

Копии заключений экологического аудита, направленные в уполномоченные органы могут включаться в Государственный реестр заключений экологического аудита.

Аудиторское заключение, по экологическому аудиту недропользования помимо информации о результатах проверки по выбранным критериям, при 
необходимости может содержать сведения о документах, подтверждающих следующее:

- права предприятия или организации на пользование объектами недропользования;

- права предприятия или организации на осуществление лицензируемых видов деятельности, связанных с эксплуатацией объекта недропользования;

- количественную и качественную оценку состояния ресурсной базы объекта недропользования на дату проведения аудита;

- соблюдение предприятием или организацией установленного порядка, правил, стандартов и условий пользования недрами;

- выполнение показателей проектных технико-экономических и технологических документов по геологическому изучению, разведке и разработке месторождений горючих полезных ископаемых;

- соблюдение предприятием или организацией установленных требований по безопасному ведению работ, охране недр и окружающей среды;

- выполнение указаний по устранению в установленные сроки нарушений, вскрытых геологической и маркшейдерской службами недропользователя, контрольных и надзорных органов;

- результаты финансово-хозяйственной деятельности предприятия, его платежи, налоги, задолженности.

В случае если аудиторской организацией сделан вывод о недостоверности документации (информации), представляемой предприятием-недропользователем, или о несоответствии его деятельности действующим нормативно-правовым актам, техническим и технологическим требованиям, а также условиям пользования недрами, в заключении должна быть приведена аргументация, подтверждающая этот вывод. 


\section{ГЛАВА 3. Концепция устойчивого развития, «Зеленая" экономика и ее верификация}

\section{1. История возникновения}

В 90-е годы 20 века в США, а затем и ряде других развитых странах (Канада, Япония, Южная Корея) появился тренд на так называемые «зеленые» проекты. «Зелеными» проектами стали называть бизнес, сокращающий вредные выбросы (в воду, атмосферу) и накопления отходов производства. Для подтверждения факта экологичности привлекали экспертов, как правило - экологических аудиторов. А процедуру подтверждения экологическим нормативам стали именовать верификацией. С понятийной точки зрения верификацию можно и нужно рассматривать как частный случай экологического аудита.

Верификация экологических технологий (ETV) впервые была применена в США в 1995 г. Позднее ее стали реализовывать Канада, страны ЕС, Япония, Южная Корея, Филиппины. В каждой из перечисленных стран внедрены собственные (национальные) ETV-программы.

В 2008 г. Была создана Международная рабочая группа по ETV (IWGETV). Группа внедряет в практику международную стандартизацию ETVпроцесса посредством международного стандарта ИCO/ETV.

На сайте Европейской Комиссии размещены материалы группы по:

- структуре ETV;

- работе над верификационными технологиями;

- эко-инновациям;

- ежегодным обзорам по внедряемым эко-инновациям (в разрезе стран ЕC).

В 1972 году в ООН была подготовлена Программа ООН по окружающей среде или ЮНЕП (United Nations Environment Programme, UNEP), которая заложила основы координации охраны природы на глобальном общесистемном уровне. UNEP определяет зеленую экономику как экономику, которая повышает благосостояние людей и обеспечивает социальную справедливость, и существенно снижает риски для окружающей среды.

В последующие годы СССР, а позднее Российская Федерация, последовательно выступали на международной арене с инициативами в области экологии и поддерживали выдвигаемые иными странами инициативы. Советский Союз присоединился к: 
- «Венской конвенции об охране озонового слоя» (заключена в г. Вене 22.03.1985);

- «Протоколу об ограничении выбросов окислов азота или их трансграничных потоков к Конвенции 1979 года о трансграничном загрязнении воздуха на большие расстояния» (подписан в г. Софии 31.10.1988);

- «Монреальскому протоколу по веществам, разрушающим озоновый слой» (подписан в г. Монреале 16.09.1987);

- «Протоколу о борьбе с подкислением, эвтрофикацией и приземным озоном к Конвенции о трансграничном загрязнении воздуха на большие расстояния 1979 года» (подписан в г. Гетеборге 30.11.1999).

Концепция «устойчивого развития» была официально сформулирована в докладе «Наше общее будущее» (Our Common Future), подготовленном Международной комиссией ООН по окружающей среде и развитию в 1987 году.

Согласно докладу, устойчивое развитие является таким гармоничным социально-экономическим развитием, которое удовлетворяет потребностям настоящего времени, но не ставит под угрозу способность будущих поколений удовлетворять свои собственные потребности.

Широкое признание термин «устойчивое развитие» получил на Конференции $\mathrm{OOH}$ по окружающей среде и развитию (United Nations Conference on Environment and Development), состоявшейся в 1992 году в Рио-де-Жанейро. На конференции был принят совместно выработанный документ Рамочная конвенция ООН об изменении климата, РКИК (Framework Conventionon Climate Change, UN FCCC) - программа действий, направленная на реализацию национальными правительствами концепции глобального устойчивого развития. С развитием глобализации и ростом влияния транснациональных корпораций и их доли в глобальной экономике, основной фокус концепции устойчивого развития стал смещаться от национального уровня к корпоративному.

Рамочная конвенция вступила в силу 21 марта 1994 года. На сегодняшний день участниками конвенции являются 196 стран (в том числе все развитые страны, включая США) и отдельно ЕС.

В декабре 1997 года был принят Киотский протокол (Kyoto Protocol) к РКИК на 3-й Конференции сторон РКИК вг. Киото (Япония). 16 февраля 2005 года протокол вступил в силу. На сегодняшний день участниками Киотского протокола являются более 190 стран.

В 2006 году при поддержке ООН была создана Международная ассоциация ответственного инвестирования (Principles for Responsible Investment, PRI) после того, как несколько крупных институциональных инвесторов из 12 стран приняли приглашение Генерального секретаря $\mathrm{OOH}$ и разработали шесть базовых Принципов ответственного инвестирования. Принципы представляют собой добровольную инициативу, в соответствии с которой компа- 
нии рассматривают экологические и социальные вопросы, а также вопросы корпоративного управления (ESG), в рамках процесса принятия инвестиционных решений с целью сближения повестки компании с ожиданиями общества. В настоящее время PRI объединяет свыше 2000 организаций из числа инвестиционных фондов, управляющих компаний и консультантов.

В 2008 году в рамках ООН были подготовлены девять совместных антикризисных инициатив, одна из которых касалась зеленой экономики и была представлена в виде доклада «Глобальный зеленый новый курс» (A Global Green New Dea IReport). В докладе впервые были сформулированы рекомендации в области государственных инвестиций, а также необходимых политических реформ, призванных инициировать переход к зеленой экономике ,повысить занятость и решить проблему хронической бедности.

В 2009 году Международная организация GRESB (Global Real Estate Sustainability Benchmark) - опубликовала первую систему оценок устойчивого развития и следования принципам ESG. Методология GRESB позволяет проводить мониторинг инфраструктурных проектов, включая энергетику, передачу электроэнергии, водоканалы, транспорт, социальную инфраструктуру, телекоммуникации и TKO. GRESB позволяет проводить оценку по трем основным направлениям по шкале от 1 до 100 баллов: недвижимость (GRESB Real Estate), долговые обязательства недвижимости (GRESB Real Estate Debt) и инфраструктура (GRESB Infrastructure). При расчете рейтинга GRESB опирается на такие показатели как качество менеджмента, политика раскрытия информации, профиль рисков, показатели работы компании-оператора, взаимодействие с заинтересованными сторонами, награды и сертификаты.

В декабре 2014 года ООН приняла и опубликовала «Основополагающие принципы развития мирового сообщества на период до 2030 года», которые позволяют удовлетворить основные потребности сегодняшнего поколения без риска для жизни и для развития будущего.

25 сентября 2015 года 193 страны приняли «Повестку дня в области устойчивого развития до 2030 года», которая включает 17 глобальных Целей устойчивого развития (ЦУР). Новые ЦУР носят комплексный и неделимый характер и обеспечивают сбалансированность всех трех компонентов устойчивого развития: экономического, социального и экологического.

Цели в области устойчивого развития:

1. Повсеместная ликвидация нищеты во всех ее формах

2. Ликвидация голода, обеспечение продовольственной безопасности, улучшение питания и содействие устойчивому развитию сельского хозяйства

3. Обеспечение здорового образа жизни и содействие благополучию для всех в любом возрасте 
4. Обеспечение всеохватного и справедливого качественного образования и поощрение возможности обучения на протяжении всей жизни для Bcex

5. Обеспечение гендерного равенства, расширение прав и возможностей всех женщин и девочек

6. Обеспечение наличия и рациональное использование водных ресурсов и санитарии для всех

7. Обеспечение доступа к не дорогостоящим, надежным, устойчивым и современным источникам энергии для всех

8. Содействие неуклонному, всеохватному и устойчивому экономическому росту, полной и производительной занятости и достойной работе для Bcex

9. Создание прочной инфраструктуры, содействие обеспечению всеохватной и устойчивой индустриализации и внедрению инноваций

10. Снижение уровня неравенства внутри стран и между ними

11. Обеспечение открытости, безопасности, жизнестойкости и устойчивости городов и населенных пунктов

12. Обеспечение рациональных моделей потребления и производства

13. Принятие срочных мер по борьбе с изменением климата и его последствиями

14. Сохранение и рациональное использование океанов, морей и морских ресурсов в интересах устойчивого развития

15. Защита, восстановление экосистем суши и содействие их рациональному использованию, рациональное управление лесами, борьба с опустыниванием, прекращение и обращение вспять процесса деградации земель и прекращение процесса утраты биологического разнообразия

16. Содействие построению миролюбивых и открытых обществ в интересах устойчивого развития, обеспечение доступа к правосудию для всех и создание эффективных, подотчетных и основанных на широком участии учреждений на всех уровнях

17. Укрепление средств достижения устойчивого развития и активизация работы механизмов глобального партнерства в интересах устойчивого развития.

Цели устойчивого развития ООН (ЦУР) носят комплексный характер, они актуальны для всех стран. В то же время, в соответствии с документом, каждая страна составляет из них список приоритетных, необходимость врешении которых существует в первую очередь, или те, которые имеют воздействие на состояние многих стран одновременно.

12 декабря 2015 года на 21-й Конференции стран РКИК в г. Париже (Франция) было принято Парижское соглашение. По состоянию на 10 июля 2018 года, все участники РКИК подписали Парижское соглашение, из них 178 участников ратифицировали его, в том числе страны ЕС, США, Индия и 
Китай. На долю стран, присоединившихся к соглашению, приходится примерно 90\%глобальных антропогенных выбросов парниковых газов. Соглашение не имеет установленного срока действия(является бессрочным). Содержащиеся в нем цели, задачи и требования к участникам рассчитаны на период до конца XXI века.

\section{2. Верификация «зеленой» экономики}

В Российской Федерации впервые попытка внедрения системы оценки была предпринята в 1995 году, когда Минприроды России выпустило приказ от 23.01.1995 № 18 «Об организации системы сертификации по экологическим требованиям для предупреждения вреда окружающей природной среде (системы экологической сертификации). Предполагалось, что функции по экологической сертификации будут выполнять эксперты - аудиторы в области экологического аудита. По результатам такой сертификации предполагалась выдача экологического сертификата соответствия.

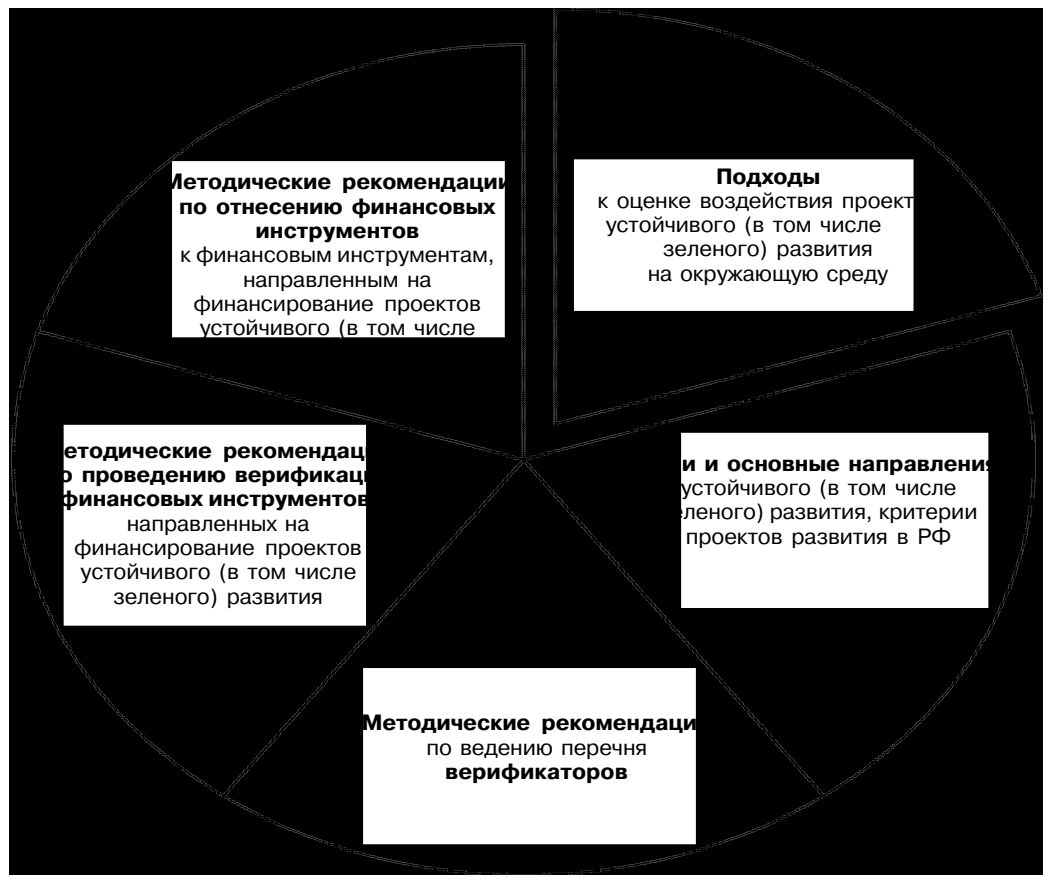

Рисунок 5. Комплект проектов нормативных документов по проектам устойчивого (в том числе «зеленого») развития. 
В настоящее время Министерством экономического развития Российской Федерации и Министерством природных ресурсов и экологии Российской Федерации разработаны проекты документов, определяющих понятия «зеленых» проектов («зеленой» экономики), порядок признания тех или иных проектов «зелеными». В процессе подготовки документов понятийный аппарат был расширен. В него включили такие понятия, как:

- проект устойчивого развития:

- адаптационный (переходный) проект.

Зеленый проект - это проект, одновременно удовлетворяющий следующим принципам:

1) соответствие одному или нескольким основным направлениям, предусмотренным целями и основными направлениями проектов устойчивого (в том числе зеленого) развития Российской Федерации (таксономия зеленых и адаптационных проектов). Зеленые проекты могут признаваться соответствующими целям и основным направлениям только при выполнении утвержденных Правительством Российской Федерации количественных и качественных критериев зеленых проектов;

2) направленность на достижение целей Парижского соглашения или одной или нескольким из следующих целей устойчивого развития $\mathrm{OOH}$ :

Цель № 6 (Чистая вода и санитария),

Цель № 7 (Доступная и чистая энергия),

Цель №8 (Достойная работа и экономический рост),

Цель №9 (Индустриализация, инновация, инфраструктура),

Цель № 11 (Устойчивые города и сообщества),

Цель №12 (Рациональное потребление и производство),

Цель № 13 (Срочные меры по борьбе с изменение климата),

Цель №14 (Рациональное использование ресурсов океана),

Цель №15 (Рациональное использование экосистем суши);

3) Реализация проекта способствует достижению целей,связанныхс положительным воздействием на окружающую среду;

4) Реализация проекта способствует достижению экологического эффекта;

5) соответствие технологическим показателям наилучших доступных технологий (далее - НДТ ${ }^{22}$ ) (достижение технологических показателей НДТ или технологических показателей лучше НДТ);

${ }^{22}$ Автор отмечает, что, например в Информационно-техническом справочнике по наилучшим доступным технологиям «ИТС 9 - 2020. Утилизация и обезвреживание отходов термическими способами» наилучшими признаются технологии, не полностью соответствующие Директиве № 2010/ 75/ЕС и технологическим показателям по Европейскому справочнику НДТ 2006 года, в то время, как в настоящее время в ЕС применяются НДТ, указанные в Европейском справочнике 2019 года. В частности, даже в Европейском справочнике от 2006 года не было предусмотрено выбросов бенза170 
6) отсутствие значимых побочных эффектов на окружающую среду (принцип «Do Not Significant Harm»). Для проектов, реализуемых на территории Российской Федерации, принцип «Do Not Significant Harm» можетсчитаться выполненным при соответствии проекта требованиям законодательства Российской Федерации в области охраны окружающей среды с учетом требований технического регулирования и стандартизации в соответствии с областью применения.

Адаптационный проект - это проект, одновременно соответствующий одному или нескольким основным направлениям, предусмотренным целями и основными направлениями. Адаптационные проекты могут признаваться соответствующими целям и основным направлениям только при выполнении утвержденных Правительством Российской Федерации количественных и качественных критериев адаптационных проектов и соответствия принципам, указанным в подпунктах 2-6.

Проект устойчивого развития - собирательное понятие, объединяющее «Зеленые» и Адаптационные проекты.

Проект Подходов к оценке воздействия проектов устойчивого (в том числе зеленого) развития в Российской Федерации на окружающую среду и климат, разработанный Министерством природных ресурсов и экологии Российской Федерации (См.: Приложение № 5) к «зеленым» проектам от-

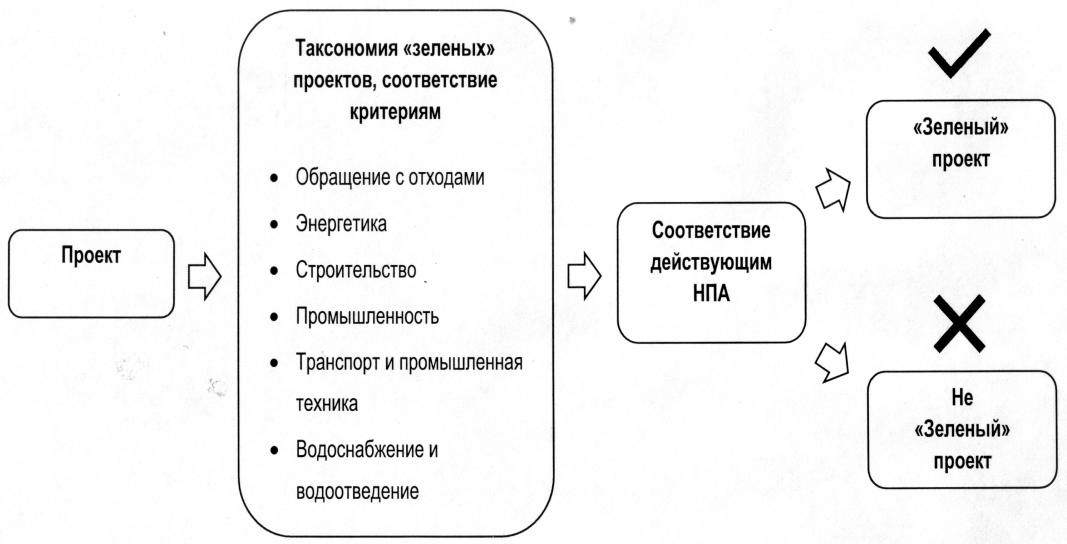

Рисунок 6. Условия и процедуры признания проекта «зеленым»

пирена, в то время, как Российский справочник предусматривает нормы выбросов бензапирена в количестве 0,001 мг/куб.м. В соответствии с ЕвропейСким справочником НДТ 2019 года нормы выбросов оксида азота, взвешенных веществ, ряда тяжелых металлов в 1,5 - 2 раза ниже, чем предусмотрены в Российском справочнике НДТ за 2020 год. Таким образом, применение устаревших норм может привести к тому, что проекты, признаваемые в Российской Федерации зелеными, в ЕС такими признаны не будут. 
носит проекты, которые соответствуют целям и основным направлениям реализации «зеленых» проектов в Российской Федерации (Таксономии "зеленых" проектов) при условии достижения указанных в Таксономии «зеленых» проектов критериев по соответствующему направлению.

Таксономия «зеленых» проектов должна соответствовать:

а) Указу Президента Российской Федерации от 07.05.2018 № 204 «О национальных целях и стратегических задачах развития Российской Федерации на период до 2024 года», Указу Президента Российской Федерации от 21.07.2020 № 474 «О национальных целях развития Российской Федерации на период до 2030 года» в части национальной цели развития «Комфортная и безопасная среда для жизни", предусматривающей следующие целевые показатели:

ликвидация наиболее опасных объектов накопленного вреда окружающей среде и экологическое оздоровление водных объектов, включая реку Волгу, озёра Байкал и Телецкое;

снижение выбросов опасных загрязняющих веществ, оказывающих наибольшее негативное воздействие на окружающую среду и здоровье человека, в два раза;

создание устойчивой системы обращения с твердыми коммунальными отходами, обеспечивающей сортировку отходов в объеме 100 процентов и снижение объема отходов, направляемых на полигоны, в два раза;

повышение качества питьевой воды для населения, в том числе для жителей населенных пунктов, не оборудованных современными системами централизованного водоснабжения;

сохранение биологического разнообразия;

б) общественно значимым результатам, указанным в паспорте Национального проекта «Экология».

Наименования основных экологических эффектов:

а) снижение выбросов загрязняющих веществ, включенных в перечень загрязняющих веществ, в отношении которых применяются меры государственного регулирования в области охраны окружающей среды, утвержденный распоряжением Правительства Российской Федерации от 08.07.2015 № 1316-р, в атмосферный воздух стационарными источниками;

б) снижение выбросов парниковых газов (в пересчете на $\mathrm{CO}_{2}$-эквивалент);

в) снижение удельных выбросов загрязняющих веществ в атмосферный воздух от передвижных источников негативного воздействия на окружающую среду (например, в расчете на кВт/ч, тонно-километр, пассажирокилометр и другие);

г) повышение уровня использования исходных сырья и материалов

и снижение потребления материальных и энергетических ресурсов (электроэнергии, теплоэнергии, топлива и другие); 
д) снижение потребления природных ресурсов;

е) сокращение удельных показателей образования отходов производства и потребления, в том числе за счет внедрения малоотходных и безотходных технологий (например, в расчете на $\mathrm{m}^{2}$ жилья, на единицу производимой продукции и другие) и снижение класса опасности отходов в источниках их образования;

ж) увеличение показателей утилизации отходов;

3) увеличение доли нормативно очищенных сточных вод в объеме сбрасываемых в поверхностные водные объекты сточных вод, требующих очистки,

и снижение концентраций загрязняющих веществ, включенных в Перечень загрязняющих веществ, в воде водного объекта до предельно допустимого уровня, соответствующего назначению объекта, и ниже;

к) увеличение площади/протяженности восстановленных водных объектов;

л) увеличение протяженности очищенной прибрежной полосы водных объектов;

м) увеличение площади лесовосстановления и лесоразведения;

н) увеличение площади территории, на которой восстановлено нарушенное состояние окружающей среды;

о) увеличение показателей сохранения биологического разнообразия.

Схожее определение уже используется во внутренних документах 000 «Национальные Кредитные Рейтинги» ${ }^{23}$.

Под верификацией проекты документов подразумевают определение соответствия финансовых инструментов устойчивого развития Методическим указаниям, по результатам которого Верификатор выпускает заключение. Автор провел сравнительный анализ использования терминологии и полагает, что данное определение сужает функционал верификации, так как, фактически, верификация проводится в 2 этапа:

- этап верификации финансовых документов устойчивого развития (или «зеленых» финансовых документов);

- этап верификации проектов устойчивого развития (или «зеленых» проектов).

Из этого следует, что более верным будет определение верификации как определения соответствия как финансовых инструментов устойчивого развития, так и определения соответствия проектов, под реализацию которых привлечены финансовые инструменты, как проектов устойчивого развития.

Определение «Верификатор» - юридическое лицо, предоставляющее заключение о соответствии финансового инструмента устойчивого развития Методическим указаниям, включенное Методологическим центром ВЭБ.РФ в перечень верификаторов, требует аналогичного уточнения.

${ }^{23}$ Методика определения соответствия финансовых инструментов критериям финансирования зеленых проектов (утв. Методологическим комитетом ООО «Национальные Кредитные Рейтинги», протокол от 16.11.2020 № 25). 


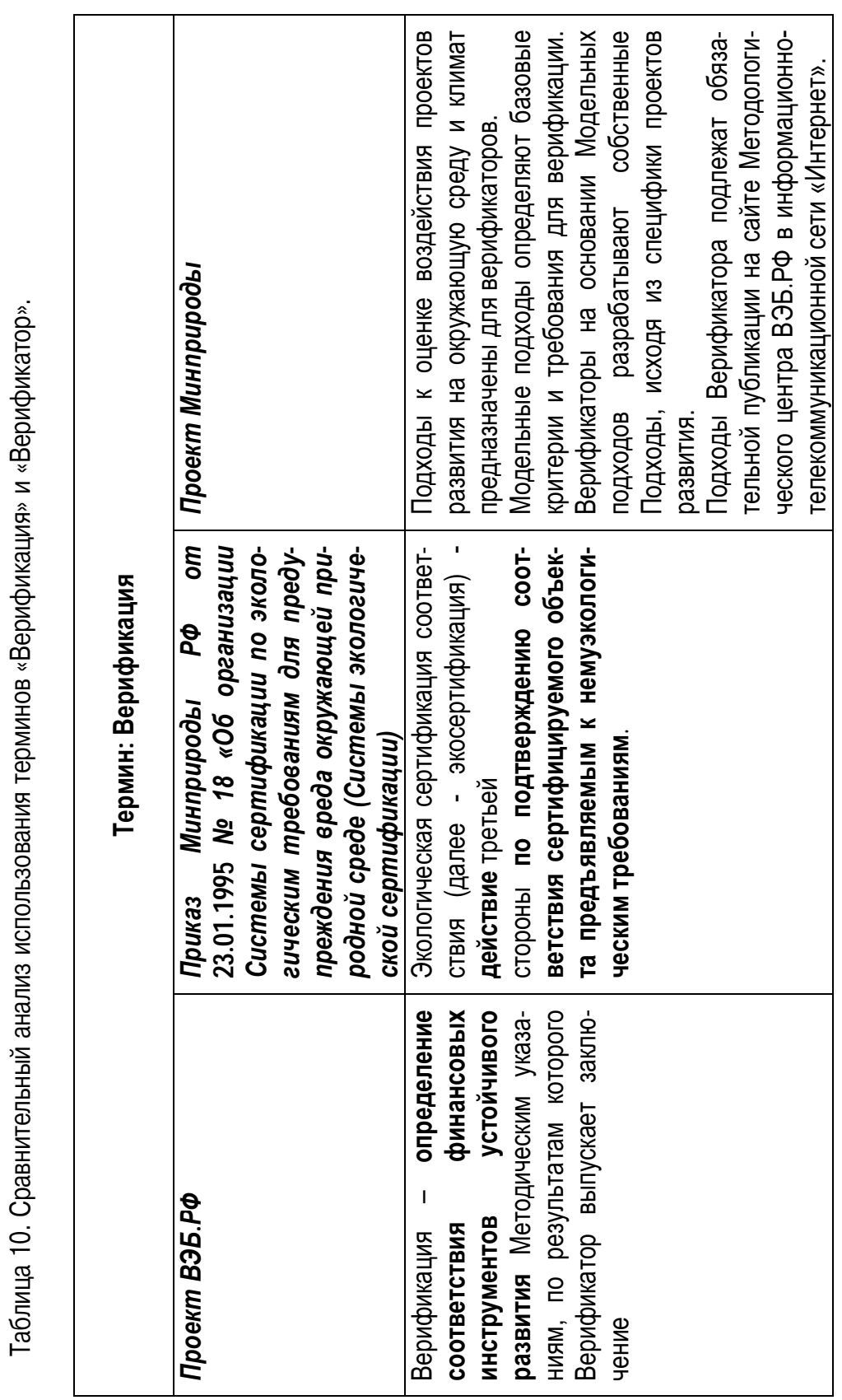




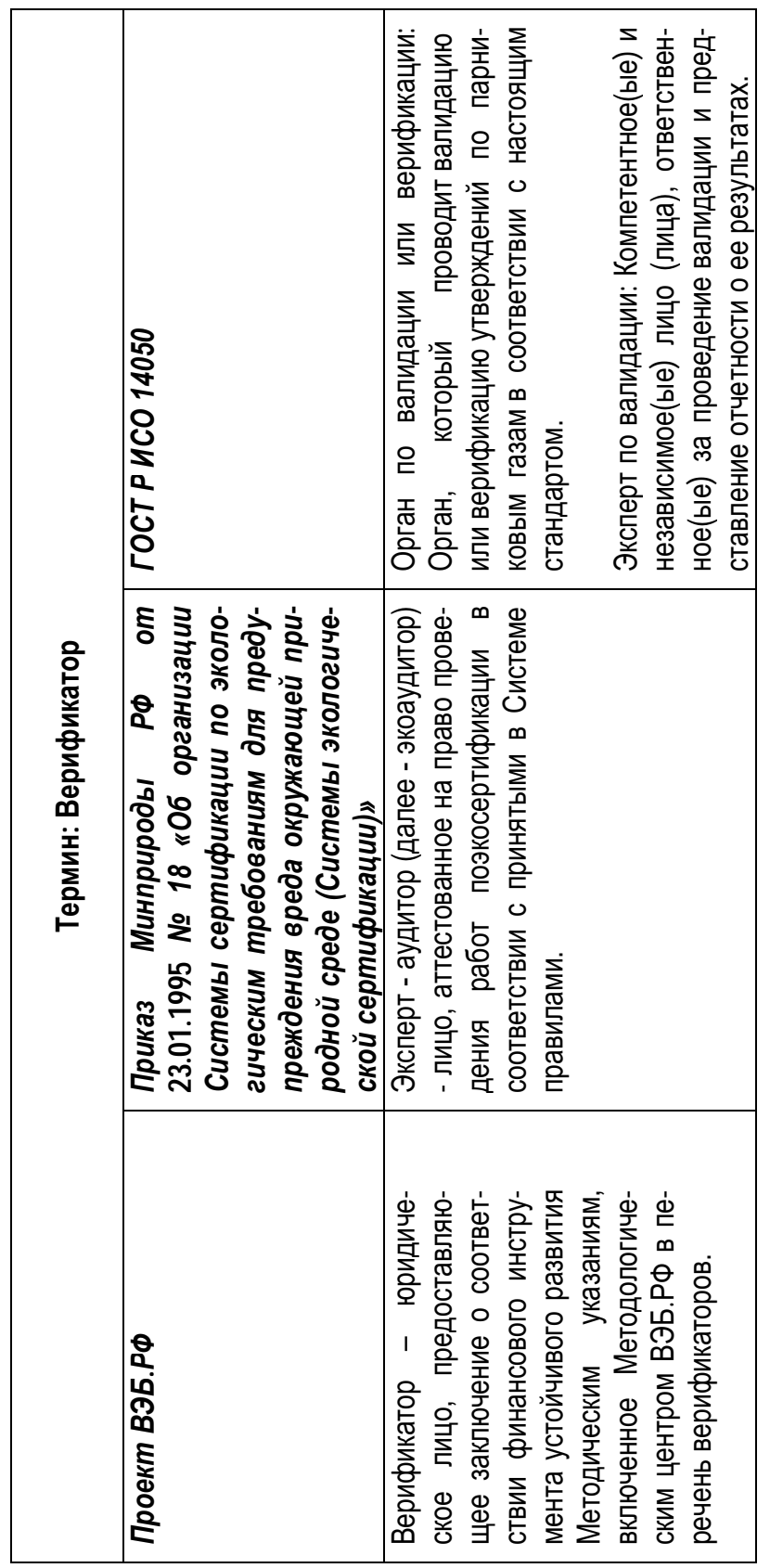




\section{3. Верификация производных финансовых инструментов "зеленой» экономики}

Зеленые финансовые инструменты - классические финансовые инструменты, посредством которых финансируются исключительно зеленые проекты. Использование данного типа финансовых инструментов требует более детального раскрытия информации для широкого круга лиц.

В диагностической записке «Зеленые финансы: повестка для России» ${ }^{24}$ эксперты, привлеченные Банком России, так описывали реперные точки появления зеленых финансовых инструментов. Рынок зеленых облигаций возник в 2007-2008 годах в результате их первых эмиссий международными банками развития. В период 2007-2010 годов основными эмитентами зеленых облигаций были Международный банк реконструкции и развития, Европейский инвестиционный банк, а также некоторые другие региональные и национальные банки развития фонды.

В 2010 году была основана Международная некоммерческая организация (Climate Bonds Initiative, CBI), ключевыми направлениями деятельности которой являются:

- проведение анализа и исследования рынка зеленых облигаций,

- разработка стандартов и системы сертификации зеленых облигаций,

- анализ законодательных инициатив на уровне стран, направленных на развитие зеленого финансирования.

В конце 2011 года СВІ был опубликован первый добровольный стандарт климатических облигаций и соответствующая схема их сертификации.

В 2012-2015 годах были разработаны и утверждены еще четыре отраслевых стандарта - для проектов по солнечной энергетике, низкоуглеродному общественному транспорту (скоростной автобус) и энергоэффективным зданиям. Кроме того, были разработаны отраслевые стандарты, которые относятся к выпуску облигаций для реализации программ и проектов в сфере ветроэнергетики, энергетики приливов, а также геотермальной энергетики.

В январе 2017 года новая опубликована стандартов СВІ, куда вошли все предыдущие стандарты, а также был расширен диапазон используемых долговых инструментов, которые могут быть сертифицированы для выпуска зеленых облигаций.

В 2014 году к идеологической методологической работе в сфере зеленых облигаций присоединилась Международная Ассоциация рынков капитала (International Capital Market Association, ICMA) - саморегулируемая организация и торговая ассоциация международного финансового рынка, которая была создана в 2005 году.

${ }^{24}$ Зеленые финансы: повестка дня для России. Диагностическая записка. // Экспертный совет по рынку долгосрочных инвестиций при Банке России. Рабочая группа по вопросам ответственного финансирования (ESGfinance), в т.ч. «зеленого» финансирования. - Москва, октябрь 2018. - 63 с. 176 
В 2014 году консорциумом инвестиционных банков Bank of America Merrill Lynch, Citi, Credit Agricole Corporate and Investment Bank, JP Morgan Chase, BNP Paribas, Daiwa, Deutsche Bank, Goldman Sachs, HSBC, Mizuho Securities, Morgan Stanley, RabobankandSEB были разработаны Принципы зеленых облигаций Green Bonds Principles - GBP,являющиеся принятыми эталонами, которым следует большинство мировых эмитентов зеленых облигаций.

В основе Green Bonds Principles лежат 4 принципа, которым должны соответствовать облигации, чтобы считаться «зелеными»:

1) направление использования средств;

2) процесс оценки и отбора проектов;

3) управление средствами;

4) отчетность (до и после эмиссии).

Соблюдение GBPs гарантирует инвесторам, что эмитент соответствует определенным стандартам в отношении того, куда направляются средства от облигаций, как выбираются проекты и какие отчеты предоставляются инвесторам. GBP являются международными принципами. C тех пор постоянный мониторинг и разработка руководящих принципов перешли в независимый секретариат, организованный ICMA.

Эмитентам зеленых облигаций рекомендуется проводить процедуру независимой внешней оценки выпуска зеленых облигаций на предмет его соответствия определенным стандартам. Такая оценка в большинстве случаев проводится на добровольной основе, но настоятельно рекомендуется. Внешняя оценка представляет собой заключение независимого эксперта, оценивающего выпуск зеленых облигаций на предмет соответствия применимым стандартам или руководствам, таким как Принципы зеленых облигаций (GBP), стандарты климатических облигаций (CBS) и др.

Эмитент может воспользоваться услугами внешних консультантов или институтов, обладающих необходимыми навыками экспертизы зеленых проектов. Экспертиза позволяет оценить риски проекта и качество действий эмитента для привлечения финансирования посредством выпуска облигаций. В среднем более $80 \%$ зеленых облигаций использовали экспертизу независимых консультантов.

Оценка для зеленых облигаций позволяет инвесторам, правительствам и акционерам удостовериться в целевом характере зеленого финансирования, а также получить доступ к системе раскрытия информации по проекту.

В случае если компания планирует получить сертификат СВІ для выпуска зеленых облигаций, для верификации зеленых облигаций на предэмиссионном этапе необходимо привлечь верификаторов, которые получили аккредитацию СВІ. Среди них консалтинговые и аудиторские компании (Deloitte, KPMG и другие), сертификационные агентства (ERM Certification and Verification Services, Kestrel Verifiers и другие), консалтинговые компании в области ответственного инвестирования и зеленых финансов (Sustainalytics, Vigeo Eiris и другие). 
Зарубежные фондовые биржи поддерживают рынок зеленого финансирования путем создания отдельной зеленой фондовой биржи, отдельного зеленой секции или перечня зеленых облигаций.

При выпуске зеленых облигаций эмитент должен учитывать ряд особенностей:

- статус зеленой эмиссии необходимо прописать в самом эмиссионном документе;

- процедура верификации является обязательной для отнесения облигаций к зеленым;

- операционные расходы (такие как расходы по размещению облигаций) не могут относиться на финансирование за счет привлеченных средств;

- эмиссионные документы должны предусматривать досрочное погашение в случае установления факта нецелевого использования привлеченных средств.

Среди мер государственной поддержки рынка зеленого финансирования, из опыта зарубежных стран можно отметить следующие:

- Обеспечение целостности рынка. Формирование принципов и стандартов зеленых облигаций на национальном уровне обеспечивает развитие надежного зеленого рынка, гарантирует поддержку правительством выпусков зеленых облигаций и помогает инвесторам контролировать уровень воздействия инвестиций на изменение климата.

- Стратегические эмиссии облигаций. Осуществление государством выпуска зеленых облигаций для обеспечения ликвидности на рынке, привлечения и обучения инвесторов. Для этих целей могут быть выпущены зеленые суверенные, муниципальные облигации, а также облигации институтов развития или зеленых банков.

- Снижение рисков. Снижение рисков осуществляется за счет масштабирования зеленых проектов и секьюритизации кредитов на этапе проектирования для обеспечения доступа к рынку облигаций институциональных инвесторов, а также выпуска обеспеченных зеленых облигаций.

- Финансовые льготы. Существуют несколько типов финансовых льгот: льготные экологические налоги и сборы, государственные гарантии, субсидии, прямое государственное финансирования на этапе подготовки, проектирования проектов, государственное страхование и др.

- Гарантия спроса. Гарантия спроса за счет госзакупок с приоритетом экологических составляющих.

В России планируют внедрить следующие виды финансовых инструментов устойчивого развития -облигации (программы облигаций) или кредиты (кредитные линии), применяемые для целей реализации или финансирования проектов устойчивого развития и(или) портфеля проектов устойчивого развития. 


\section{ГЛАВА 4. Экологическая отчетность}

\section{1. Публичная социально-экологическая отчетность компаний и дополнительная информация, включаемая в финансовую отчетность}

Традиционно в корпоративной отчетности основное внимание уделялось финансовым аспектам, волнующим, в частности, акционеров. Между тем растущий интерес к социальной ответственности компаний и устойчивому развитию повышает спрос на информацию по более широкому спектру вопросов, связанных с результатами деятельности, в частности по отношениям с персоналом, участию в жизни местных сообществ и экологическому воздействию.

В силу требований национального законодательства или регуляторов рынка (например, центральных банков, фондовых бирж) для различных компаний может быть установлен целый перечень обязательных видов отчетности:

- бухгалтерская отчетность по российским стандартам и МСФО;

- налоговая отчетность;

- статистическая отчетность;

- специализированная отраслевая отчетность в контролирующие государственные органы;

- отчетность эмитента эмиссионных ценных бумаг;

- годовой отчет акционерного общества.

В соответствии с ПБУ 4/9925 бухгалтерская отчетность должна давать достоверное и полное представление о финансовом положении организации, финансовых результатах ее деятельности и изменениях в ее финансовом положении. Если при составлении бухгалтерской отчетности организацией выявляется недостаточность данных для формирования полного представления о финансовом положении организации, финансовых результатах ее деятельности и изменениях в ее финансовом положении, то в бухгалтерскую отчетность организация включает соответствующие дополнительные показатели и пояснения.

При раскрытии дополнительной информации, например природоохранных мероприятий, приводятся основные проводимые и планируемые орга-

${ }^{25}$ Приказ Минфина РФ от 06.07.1999 № 43н «Об утверждении Положения по бухгалтерскому учету «Бухгалтерская отчетность организации» (ПБУ 4/99)». 
низацией мероприятия в области охраны окружающей среды, влияние этих мероприятий на уровень вложений долгосрочного характера и доходности в отчетном году, характеристику финансовых последствий для будущих периодов, данные о платежах за нарушение природоохранного законодательства, экологических платежах и плате за природные ресурсы, текущих расходах по охране окружающей среды и степени их влияния на финансовые результаты организации.

Для целей раскрытия организациями в бухгалтерской отчетности указанной информации целесообразно учитывать документ ПЗ-7/2011 «О бухгалтерском учете, формировании и раскрытии в бухгалтерской отчетности информации об экологической деятельности организаций» ${ }^{26}$.

Одной из самых масштабных инициатив в сфере расширения открытости компаний является финансируемая $\mathrm{OOH}$ программа Global Reporting Initiative, нацеленная на систематизацию практики раскрытия информации о социальном и экологическом воздействии компаний, которая сегодня активно реализуется компаниями в Европе и в меньшей степени в других частях мира.

Наряду с обязательной отчетностью немало компаний в России и мире составляют и добровольную отчетность. Публичная нефинансовая отчетность - один из примеров такой отчетности.

Наиболее распространенным в мире стандартом подготовки публичной нефинансовой отчетности является Руководство по отчетности в области устойчивого развития организации Global Reporting Initiative (GRI).

Правительством Российской Федерации была принята Концепция развития публичной нефинансовой отчетности ${ }^{27}$,направленная на:

совершенствование системы стимулирования российских организаций к повышению информационной открытости и прозрачности результатов воздействия их деятельности на общество и окружающую среду, включая экономическую, экологическую и социальную составляющие;

расширение возможностей для объективной оценки на основе публичной нефинансовой отчетности вклада результатов деятельности российских организаций в общественное развитие.

Открытость компаний способствует как повышению доверия общества к бизнесу, так и повышения доверия инвесторов. Улучшение инвестиционного климата позволяет государству развиваться более динамично.

${ }^{26}$ Письмо Минфина РФ от 27.05.2011 № ПЗ-7/2011 «О бухгалтерском учете, формировании и раскрытии в бухгалтерской отчетности информации об экологической деятельности организации».

${ }^{27}$ Распоряжение Правительства РФ от 05.05.2017 № 876-р<Об утверждении Концепции развития публичной нефинансовой отчетности и плана мероприятий по ее реализации>. 


\section{Заключение}

Данная работа ставила задачу систематизации знаний в сфере регулирования экологических вопросов как для менеджмента коммерческих организаций, так и для органов государственной власти и местного самоуправления.

В вопросах проведения экологической экспертизы, организации экологического аудита, разработки стандартов публичной экологической отчетности компаний, государственной поддержки проектов устойчивого развития (в том числе «зеленых» проектов) есть еще много не решенных вопросов.

Среди первоочередных проблем автор выделяет:

- отсутствует регламентного межведомственного закрепления обязательности проведения государственной экологической экспертизы;

- отсутствие методического обеспечения по проведению государственной субъектов Российской Федерации и общественной экологической экспертизы;

- отсутствие методического обеспечения по проведению регионального и муниципального экологического контроля;

- отсутствие достаточного правового закрепления развития экологического аудита.

Жизнь ставит задачу первоочередного решения экологических проблем. Это главный современный вызов всему человечеству. 


\section{БИБЛИОГРАФИЧЕСКИЙ СПИСОК}

\section{Основные правовые акты}

1. Конституция Российской Федерации.

2. Закон РСФСР от 19.12.1991 № 2060-1 «Об охране окружающей природной среды» (отменен).

3. Федеральный закон Российской Федерации от 17.02.1995 № 16-Ф3 «0 ратификации Конвенции о биологическом разнообразии".

4. Федеральный закон Российской Федерации от 24.04.1995 № 52-Ф3 «О животном мире».

5. Федеральный закон Российской Федерации от 23.11.1995 № 174-Ф3 «Об экологической экспертизе».

6. Федеральный закон Российской Федерации от 30.11.1995 № 187-Ф3 «О континентальном шельфе Российской Федерации».

7. Федеральный закон Российской Федерации от 13.06.1996 № 63-Ф3 «Уголовный кодекс Российской Федерации».

8. Федеральный закон Российской Федерации от 02.05.1997 № 76-Ф3 «Об уничтожении химического оружия».

9. Федеральный закон Российской Федерации от 19.07.1997 № 109-Ф3 «О безопасном обращении с пестицидами и агрохимикатами".

10. Федеральный закон Российской Федерации от 21.07.1997 № 116-Ф3 «О промышленной безопасности опасных производственных объектов».

11. Федеральный закон Российской Федерации от 24.06.1998 № 89-Ф3 «Об отходах производства и потребления».

12. Федеральный закон Российской Федерации от 31.07.1998 № 155-Ф3 "О внутренних морских водах, территориальном море и прилежащей зоне Российской Федерации».

13. Федеральный закон Российской Федерации от 17.12.1998 № 191-Ф3 «Об исключительной экономической зоне Российской Федерации».

14. Федеральный закон Российской Федерации от 01.05.1999 № 94-Ф3 «Об охране озера Байкал».

15. Федеральный закон Российской Федерации от 04.05.1999 № 96-Ф3 «Об охране атмосферного воздуха».

16. Федеральный закон Российской Федерации от 10.07.2001 № 92-Ф3 «О специальных экологических программах реабилитации радиационно загрязненных участков территории».

17. Федеральный закон Российской Федерацииот 08.08.2001 № 129-Ф3 «О государственной регистрации юридических лиц и индивидуальных предпринимателей».

18. Федеральный закон Российской Федерации от 25.10.2001 № 136-Ф3 «Земельный кодекс Российской Федерации». 
19. Федеральный закон Российской Федерации от 21.12.2001 № 178-Ф3 «О приватизации государственного и муниципального имущества».

20. Федеральный закон Российской Федерации от 30.12.2001 № 195-Ф3 «Кодекс Российской Федерации об административных правонарушениях".

21. Федеральный закон Российской Федерации от 10.01.2002 № 7-Ф3 «Об охране окружающей среды».

22. Федеральный закон Российской Федерации от 26.10.2002 № 127-Ф3 "О несостоятельности (банкротстве)».

23. Федеральный закон Российской Федерации от 29.07.2004 № 98-Ф3 «О коммерческой тайне».

24. Федеральный закон Российской Федерации от 21.12.2004 № 172-Ф3 "О переводе земель или земельных участков из одной категории в другую". 25. Федеральный закон Российской Федерации от 29.12.2004 № 190-Ф3 «Градостроительный кодекс Российской Федерации».

26. Федеральный закон Российской Федерации от 03.06.2006 № 74-Ф3 «Водный кодекс Российской Федерации».

27. Федеральный закон Российской Федерации от 01.12.2007 № 310-Ф3 «Об организации и о проведении XXII Олимпийских зимних игр и XI Паралимпийских зимних игр 2014 года в городе Сочи, развитии города Сочи как горноклиматического курорта и внесении изменений в отдельные законодательные акты Российской Федерации».

28. Федеральный закон Российской Федерации от 08.05.2009 № 93-Ф3 «Об организации проведения встречи глав государств и правительств стран - участников форума «Азиатско-тихоокеанское экономическое сотрудничество» в 2012 году, о развитии города Владивостока как центра международного сотрудничества в Азиатско-Тихоокеанском регионе и о внесении изменений в отдельные законодательные акты Российской Федерации».

29. Федеральный закон Российской Федерации от 24.07.2009 № 209-Ф3 "Об охоте и о сохранении охотничьих ресурсов и о внесении изменений в отдельные законодательные акты Российской Федерации».

30. Федеральный закон Российской Федерации от 27.07.2010 № 210-Ф3 «Об организации предоставления государственных и муниципальных услуг».

31. Федеральный закон Российской Федерации от 06.04.2011 № 63-Ф3 «Об электронной подписи».

32. Федеральный закон Российской Федерации от 04.05.2011 № 99-Ф3 «О лицензировании отдельных видов деятельности".

33. Федеральный закон Российской Федерации от 19.07.2011 № 246-Ф3 «Об искусственных земельных участках, созданных на водных объектах, находящихся в федеральной собственности, и о внесении изменений в отдельные законодательные акты Российской Федерации».

34. Федеральный закон Российской Федерации от 07.06.2013 № 108-Ф3 «О подготовке и проведении в Российской Федерации чемпионата мира по футболу FIFA 2018 года, Кубка конфедераций FIFA 2017 года и внесении изменений в отдельные законодательные акты Российской Федерации». 
35. Федеральный закон Российской Федерации от 29.12.2014 № 473-Ф3 «О территориях опережающего социально-экономического развития в Российской Федерации".

36. Федеральный закон Российской Федерации от 13.07.2015 № 221-Ф3 «Об особенностях регулирования отдельных правоотношений, возникающих в связи со строительством, с реконструкцией объектов транспортной инфраструктуры федерального и регионального значения, предназначенных для обеспечения транспортного сообщения между Таманским и Керченским полуостровами, и объектов инженерной инфраструктуры федерального и регионального значения на Таманском и Керченском полуостровах и о внесении изменений в отдельные законодательные акты Российской Федерации».

37. Указ Президента Российской Федерации от 10.07.2001 № 828 «О специальной комиссии по вопросам ввоза на территорию Российской Федерации облученных тепловыделяющих сборок зарубежного производства».

38. Указ Президента Российской Федерации от 19.04.2017 № 176 «О Стратегии экологической безопасности Российской Федерации на период до 2025 года».

39. Указ Президента Российской Федерации от 07.05.2018 № 204 «О национальных целях и стратегических задачах развития Российской Федерации на период до 2024 года».

40. Указ Президента Российской Федерации от 21.07.2020 № 474 «0 национальных целях развития Российской Федерации на период до 2030 года».

41. «Основы государственной политики в области экологического развития Российской Федерации на период до 2030 года» (утв. Президентом Российской Федерации 30.04.2012).

42. Постановление Совмина СССР от 01.03.1990 № 237 «О мерах по обеспечению выполнения обязательств Советской Стороны, вытекающих из Монреальского протокола по веществам, разрушающим озоновый слой, к венской конвенции об охране озонового слоя».

43. Постановление Совмина СССР от 22.09.1988 № 1108 «О принятии СССР Монреальского протокола по веществам, разрушающим озоновый слой, к Венской конвенции об охране озонового слоя».

44. Постановление Совмина СССР от 12.04.1990 № 363 «О мерах по обеспечению выполнения обязательств Советской Стороны, вытекающих из Протокола об ограничении выбросов окислов азота или их трансграничных потоков к Конвенции 1979 года о трансграничном загрязнении воздуха на большие расстояния».

45. Постановление Правительства РСФСР от 05.12.1991 № 35 «О перечне сведений, которые не могут составлять коммерческую тайну».

46. Постановление Правительства Российской Федерации от 22.09.1993 № 942 «Об утверждении Положения о государственной экологической экспертизе».

47. Постановление Правительства Российской Федерации от 24.12.1994 № 1418 «Об утверждении Положения о лицензировании отдельных видов деятельности». 
48. Постановление Правительства РФ от 01.07.1995 № 669 «О мерах по выполнению Конвенции о биологическом разнообразии» (вместе с «Положением о Межведомственной комиссии по проблемам биологического разнообразия»).

49. Постановление Правительства Российской Федерации от 26.02.1996 № 168 «Об утверждении Положения о лицензировании отдельных видов деятельности в области охраны окружающей среды».

50. Постановление Правительства Российской Федерации от 01.05.1996 № 534 «0 дополнительном стимулировании частных инвестиций в Российской Федерации».

51. Постановление Правительства Российской Федерации от 11.06.1996 № 698 «Об утверждении Положения о порядке проведения Государственной экологической экспертизы» (отменено).

52. Постановление Правительства Российской Федерации от 07.12.1996 № 1425 «Об утверждении Положения об округах санитарной и горно-санитарной охраны лечебно-оздоровительных местностей и курортов федерального значения».

53. Постановление Правительства Российской Федерации от 07.12.1996 № 1426 «Об утверждении Положения о признании территорий лечебно - оздоровительными местностями и курортами федерального значения».

54. Постановление Правительства Российской Федерации от 13.08.1997 № 1009 «Об утверждении Правил подготовки нормативных правовых актов федеральных органов исполнительной власти и их государственной регистрации».

55. Постановление Правительства Российской Федерации от 24.02.1999 № 208 «Об утверждении Положения о зоне защитных мероприятий, устанавливаемой вокруг объектов по хранению химического оружия и объектов по уничтожению химического оружия».

56. Постановление Правительства Российской Федерации от 25.08.1999 № 941 «О разработке и согласовании консолидированных схем градостроительного планирования и основных положений консолидированных схем градостроительного планирования» (вместе с «Основными требованиями ...»).

57. Постановление Правительства Российской Федерации от 20.06.2000 № 471 «Об утверждении Положения о лицензировании деятельности по использованию радиоактивных материалов при проведении работ по использованию атомной энергии в оборонных целях» (отменено).

58. Постановление Правительства Российской Федерации от 15.12.2000 № 973 «Об экспорте и импорте ядерных материалов, оборудования, специальных неядерных материалов и соответствующих технологий».

59. Постановление Правительства Российской Федерации от 15.04.2002 № 240 «О порядке организации мероприятий по предупреждению и ликвидации разливов нефти и нефтепродуктов на территории Российской Федерации» (отменено). 
60. Постановление Правительства Российской Федерации от 17.05.2002 № 318 «Об утверждении Соглашения о контроле за трансграничной перевозкой опасных и других отходов и Соглашения об основных принципах взаимодействия в области рационального использования и охраны трансграничных водных объектов».

61. Постановление Правительства Российской Федерации от 11.07.2002 № 514 «Об утверждении Положения о согласовании и утверждении землеустроительной документации, создании и ведении государственного фонда данных, полученных в результате проведения землеустройства».

62. Постановление Правительства Российской Федерации от 11.07.2003 № 418 «О порядке ввоза в Российскую Федерацию облученных тепловыделяющих сборок ядерных реакторов» (вместе с «Положением о ввозе в Российскую Федерацию облученных тепловыделяющих сборок ядерных реакторов»).

63. Постановление Правительства Российской Федерации от 22.12.2004 № 827 «Об утверждении Положения о рассмотрении заявок на получение права пользования недрами для целей захоронения радиоактивных отходов и отходов I - V классов опасности в глубоких горизонтах, обеспечивающих локализацию таких отходов».

64. Постановление Правительства Российской Федерации от 28.01.2006 № 48 "О составе и порядке подготовки документации о переводе земель лесного фонда в земли иных (других) категорий» (отменено).

65. Постановление Правительства Российской Федерации от 30.12.2006 № 881 «О порядке утверждения нормативов допустимого воздействия на водные объекты».

66. Постановление Правительства Российской Федерации от 30.12.2006 № 883 «О порядке разработки, утверждения и реализации схем комплексного использования и охраны водных объектов, внесения изменений в эти схемы».

67. Постановление Правительства Российской Федерации от 16.02.2008 № 87 «0 составе разделов проектной документации и требованиях к их содержанию».

68. Постановление Правительства Российской Федерации от 07.11.2008 № 822 «Об утверждении Правил представления проектной документации объектов, строительство, реконструкцию, капитальный ремонт которых предполагается осуществлять на землях особо охраняемых природных территорий, для проведения государственной экспертизы и государственной экологической экспертизы».

69. Постановление Правительства Российской Федерации от 25.06.2009 № 531 «Об определении и утверждении общего допустимого улова водных биологических ресурсов и его изменении» (вместе с «Положением об определении и утверждении общего допустимого улова водных биологических ресурсов и его изменении»).

70. Постановление Правительства Российской Федерации от 09.06.2010 № 417 «Об утверждении Правил выдачи разрешений на прокладку подвод- 
ных кабелей и трубопроводов на континентальном шельфе Российской Федерации и Правил выдачи разрешений на проведение буровых работ для целей, не связанных с региональным геологическим изучением, геологическим изучением, разведкой и добычей минеральных ресурсов континентального шельфа Российской Федерации».

71. Постановление Правительства Российской Федерации от 03.10.2015 № 1062 «О лицензировании деятельности по сбору, транспортированию, обработке, утилизации, обезвреживанию, размещению отходов I - IV классов опасности» (вместе с «Положением о лицензировании деятельности по сбору, транспортированию, обработке, утилизации, обезвреживанию, размещению отходов I - IV классов опасности") (отменено).

72. Постановление Правительства Российской Федерации от 22.01.2013 № 23 «О Правилах разработки и утверждения профессиональных стандарTOB».

73. Постановление Правительства Российской Федерации от 29.03.2013 № 280 «О лицензировании деятельности в области использования атомной энергии» (вместе с «Положением о лицензировании деятельности в области использования атомной энергии»).

74. Постановление Правительства Российской Федерации от 29.11.2018 № 1730 «Об утверждении особенностей возмещения вреда, причиненного лесам и находящимся в них природным объектам вследствие нарушения лесного законодательства».

75. Постановление Правительства Российской Федерации от 07.11.2020 № 1796 «Об утверждении Положения о проведении государственной экологической экспертизы».

76. Постановление Правительства Российской Федерации от 26.12.2020 № 2290 «О лицензировании деятельности по сбору, транспортированию, обработке, утилизации, обезвреживанию, размещению отходов I - IV классов опасности» (вместе с «Положением о лицензировании деятельности по сбору, транспортированию, обработке, утилизации, обезвреживанию, размещению отходов I - IV классов опасности»).

77. Постановление Правительства Российской Федерации от 31.12.2020 № 2451 «Об утверждении Правил организации мероприятий по предупреждению и ликвидации разливов нефти и нефтепродуктов на территории Российской Федерации, за исключением внутренних морских вод Российской Федерации и территориального моря Российской Федерации, а также о признании утратившими силу некоторых актов Правительства Российской Федерации".

78. Постановление Правительства Российской Федерации от 18.09.2020 № 1496 «О признании утратившими силу некоторых актов и отдельных положений некоторых актов Правительства Российской Федерации, об отмене некоторых нормативных правовых актов федеральных органов исполнительной власти, содержащих обязательные требования, соблюдение которых оценивается при проведении мероприятий по контролю при осуществлении государственного экологического надзора». 
79. Распоряжение Правительства Российской Федерации от 31.08.2002 № 1225-р <Об Экологической доктрине Российской Федерации>.

80. Распоряжение Правительства Российской Федерации от 17.11.2008 № 1662-р <0 Концепции долгосрочного социально-экономического развития Российской Федерации на период до 2020 года> (вместе с «Концепцией долгосрочного социально-экономического развития Российской Федерации на период до 2020 года»).

81. Распоряжение Правительства Российской Федерации от 22.11.2008 № 1734-р <0 Транспортной стратегии Российской Федерации>.

82. Распоряжение Правительства Российской Федерации от 05.07.2010 № 1120-р <Об утверждении Стратегии социально-экономического развития Сибири до 2020 года>.

83. Распоряжение Правительства Российской Федерации от 05.09.2011 № 1538-р <Об утверждении Стратегии социально-экономического развития Южного федерального округа до 2020 года>.

84. Распоряжение Правительства Российской Федерации от 18.11.2011 № 2074-р <Об утверждении Стратегии социально-экономического развития Северо-Западного федерального округа на период до 2020 года>.

85. Распоряжение Правительства Российской Федерации от 08.07.2015 № 1316-р <Об утверждении перечня загрязняющих веществ, в отношении которых применяются меры государственного регулирования в области охраны окружающей среды>.

86. Распоряжение Правительства Российской Федерации от 05.05.2017 № 876-р <0 Концепции развития публичной нефинансовой отчетности>.

87. Распоряжение Правительства Российской Федерации от 29.05.2019 № 1124-р <Об утверждении плана мероприятий по реализации Стратегии экологической безопасности Российской Федерации на период до 2025 года>.

88. Приказ Минприроды РФ от 23.01.1995 № 18 «Об организации Системы сертификации по экологическим требованиям для предупреждения вреда окружающей природной среде (Системы экологической сертификации)».

89. Приказ Минприроды РФ от 28.09.1995 № 392 «Об утверждении единой формы Заключения государственной экологической экспертизы».

90. Приказ Минприроды РФ от 11.10.1995 № 412 «Об экологическом аудировании».

91. Приказ Минприроды РФ от 29.12.1995 № 539 «Об утверждении «Инструкции по экологическому обоснованию хозяйственной и иной деятельности".

92. Приказ Минприроды РФ от 29.12.1995 № 540 «Об организации экологического аудита».

93. Приказ Минприроды РФ от 28.03.1996 № 113 «Об утверждении Требований к материалам, представляемым на государственную экологическую экспертизу для отнесения отдельных участков территории Российской Федерации к зонам чрезвычайной экологической ситуации или экологического бедствия» 
94. Приказ Минприроды РФ от 13.08.1996 № 362 «О выполнении постановления Правительства Российской Федерации от 11.06.1996 № 698 «Об утверждении Положения о порядке проведения государственной экологической экспертизы».

95. Приказ Госкомэкологии РФ от 25.09.1997 №397 «Об утверждении «Перечня нормативных документов, рекомендуемых к использованию при проведении государственной экологической экспертизы, а также при составлении экологического обоснования хозяйственной и иной деятельности».

96. Приказ Госкомэкологии РФ от 17.02.1998 № 94 «Об эксперименте по проведению экологического аудита на территории Санкт-Петербурга и Ленинградской области».

97. Приказ Госкомэкологии РФ от 30.03.1998 № 181 «Об экологическом аудировании в системе Госкомэкологии России".

98. Приказ Минприроды РФ от 02.04.1998 № 95 «О создании системы аудита недропользования» (вместе с «Основными положениями аудита недропользования»).

99. Приказ Госкомэкологии РФ от 16.07.1998 № 436 «О проведении практических работ по введению экологического аудирования в Российской Федерации» (вместе с «Временным порядком аттестации экологических аудиторов»).

100. Приказ Госкомэкологии РФ от 16.05.2000 № 372 «Об утверждении Положения об оценке воздействия намечаемой хозяйственной и иной деятельности на окружающую среду в Российской Федерации».

101. Приказ Минприроды РФ от 30.10.2008 № 273 «Об утверждении Административного регламента исполнения Министерством природных ресурсов и экологии Российской Федерации государственной функции по надзору за правовым регулированием органами государственной власти субъектов Российской Федерации вопросов осуществления переданных полномочий Российской Федерации в области водных отношений, государственной экологической экспертизы, объектов животного мира и среды их обитания, охоты и сохранения охотничьих ресурсов с правом направления обязательных для исполнения предписаний об отмене нормативных правовых актов субъектов Российской Федерации или о внесении в них изменений».

102. Приказ Минприроды РФ от 13.04.2009 № 87 «Об утверждении Методики исчисления размера вреда, причиненного водным объектам вследствие нарушения водного законодательства».

103. Приказ Минприроды РФ от 22.07.2011 № 645 «Об утверждении форм и содержания представления отчетности об осуществлении органами государственной власти субъектов Российской Федерации переданных полномочий Российской Федерации в области экологической экспертизы».

104. Приказ Минприроды РФ от 29.06.2012 № 190 «Об утверждении Административного регламента Федеральной службы по надзору в сфере природопользования по исполнению государственной функции по контролю и надзору за полнотой и качеством осуществления органами государственной 
власти субъектов Российской Федерации переданных полномочий в области государственной экологической экспертизы с правом направления предписаний об устранении выявленных нарушений, а также о привлечении к ответственности должностных лиц, исполняющих обязанности по осуществлению переданных полномочий».

105. Приказ Минприроды РФ от 23.09.2013 № 404 «Об утверждении Порядка оплаты труда внештатных экспертов государственной экологической экспертизы».

106. Приказ Минприроды России от 06.05.2014 № 204 «Об утверждении Административного регламента Федеральной службы по надзору в сфере природопользования по предоставлению государственной услуги по организации и проведению государственной экологической экспертизы федерального уровня».

107. Приказ Минприроды России от 12.05.2014 № 205 «Об утверждении Порядка определения сметы расходов на проведение государственной экологической экспертизы».

108. Приказ Минприроды России от 25.12.2018 № 684 «Об утверждении содержания ходатайства о переводе земель лесного фонда в другую категорию и состава прилагаемых к нему документов».

109. Приказ Минприроды России от 27.11.2020 № 981 «Об утверждении Порядка подготовки, принятия документа об утверждении лимита добычи охотничьих ресурсов, внесения в него изменений и требований к его содержанию и составу».

110. Приказ Минприроды России от 01.12.2020 № 999 «Об утверждении требований к материалам оценки воздействия на окружающую среду».

111. Приказ Минприроды России от 28.01.2021 № 59 «Об утверждении Методики исчисления размера вреда, причиненного атмосферному воздуху как компоненту природной среды».

112. «Общие требования к центрам по обучению специалистов в области экологического аудита в системе Госкомэкологии России и порядок их аккредитации» (утверждено Госкомэкологии РФ 31.05.1999 №01-22/24-154).

113. Приказ Росприроднадзора от 30.12 .2005 № 369 «Об утверждении норматива накладных расходов при определении стоимости проведения государственной экологической экспертизы в Федеральной службе по надзору в сфере природопользования».

114. Приказ Росприроднадзора от 11.04.2011 № 207 «Об утверждении форм и порядке оперативной отчетности территориальных органов Росприроднадзора по осуществлению разрешительной деятельности в части экологического нормирования, регулирования обращения с отходами и государственной экологической экспертизы».

115. Приказ Росприроднадзора от 06.07.2020 № 783 «Об утверждении Административного регламента Федеральной службы по надзору в сфере природопользования по осуществлению федерального государственного экологического надзора». 
116. Приказ Минэнерго России от 23.07.2012 № 340 «Об утверждении перечня предоставляемой субъектами электроэнергетики информации, форм и порядка ее предоставления».

117. Приказ Минпромэнерго РФ от 04.07.2006 № 141 «Об утверждении Рекомендаций по проведению энергетических обследований (энергоаудита)».

118. Приказ Минпромэнерго РФ от 16.04.2008 № 189 «Об обеспечении Министерства промышленности и энергетики Российской Федерации документированной отчетной информацией субъектов электроэнергетики».

119. Приказ Минсельхоза России от 31.03.2020 № 167 «Об утверждении Методики исчисления размера вреда, причиненного водным биологическим ресурсам».

120. Приказ Минтруда России от 07.09.2020 № 569н «Об утверждении профессионального стандарта «Специалист по экологической безопасности (в промышленности)".

121. Приказ Минфина РФ от 06.07.1999 № 43н «Об утверждении Положения по бухгалтерскому учету «Бухгалтерская отчетность организации» (ПБУ 4/99)».

122. Приказ Минфина России от 09.01.2019 № 2н «О введении в действие международных стандартов аудита на территории Российской Федерации и о признании утратившими силу некоторых приказов Министерства финансов Российской Федерации».

123. Приказ Федерального агентства по рыболовству от 09.03.2010 № 158 "Об утверждении Административного регламента Федерального агентства по рыболовству по исполнению государственной функции по разработке и представлению на государственную экологическую экспертизу, а также определение и утверждение ежегодно общих допустимых уловов водных биологических ресурсов во внутренних водах Российской Федерации, в том числе во внутренних морских водах Российской Федерации, а также в территориальном море РоссийскойФедерации, на континентальном шельфе и в исключительной экономической зоне Российской Федерации, в Азовском и Каспийском морях».

124. Приказ Росгидромета от 03.07.2020 № 247 «О введении в действие руководящего документа РД 52.04.893-2020 «Массовая концентрация взвешенных веществ в пробах атмосферного воздуха. Методика измерений гравиметрическим методом».

125. Постановление «Об использовании методологии оценки риска для управления качеством окружающей среды и здоровья населения в Российской Федерации (утверждено Главным государственным санитарным врачом РФ 10.11.1997 № 25 и Главным государственным инспектором РФ по охране природы от 10.11.1997 № 03-19/24-3483.

126. Постановление Главного государственного санитарного врача РФ от 16.06.2003 № 144 «О введении в действие СП 2.1.7.1386-03» (вместе с «СП 2.1.7.1386-03. 2.1.7. Почва, очистка населенных мест, отходы производства и потребления. Санитарные правила по определению класса опасности токсичных отходов производства и потребления. Санитарные правила»). 
127. Р 2.1.10.1920-04 «Руководство по оценке риска для здоровья населения при воздействии химических веществ, загрязняющих окружающую среду» (утвержденоГлавным государственным санитарным врачом РФ 05.03.2004).

128. «Временные методические указания по проведению комплексной экологической оценки состояния атмосферного воздуха большого города» (введены письмом ДГЭК Минприроды России от 25.12.1995 № 11-02/02-594).

129. «Инструкция по проектированию, эксплуатации и рекультивации полигонов для твердых бытовых отходов» (утв. Минстроем России 02.11.1996).

130. Письмо Госкомэкологии РФ от 20.11.1997 № 02-13/29-3628 «O «Peкомендациях по оформлению документов при организации и проведении государственной экологической экспертизы намечаемой хозяйственной деятельности (примерное содержание)».

131. Письмо Минприроды РФ от 13.05.2011 № 05-12-44/7250 «О проведении государственной экологической экспертизы проектов технической документации на новые технику, технологию».

132. Письмо Минприроды России от 30.10.2012 № 12-50/4431-ОГ «О рассмотрении обращения».

133. Письмо Минприроды России от 19.05.2014 № 05-12-44/10285 «О разъяснении законодательства по вопросу размещения отходов организациями, производящими добычу полезных ископаемых».

134. Письмо Минприроды России от 02.06.2014 № 05-12-44/11342 «Об использовании отходов производства и потребления для рекультивации карьерных выемок и искусственно созданных полостей».

135. Письмо Минприроды России от 18.08.2014 № 05-12-44/18132 «По вопросу разъяснения применения природоохранного законодательства Российской Федерации при отнесении иловых осадков к отходам производства».

136. Письмо Минприроды России от 05.09.2014 № 05-12-44/20156 «0 ведении государственного реестра объектов размещения отходов».

137. Письмо Минприроды России от 29.07.2015 № 12-47/17563 «Об изменении требований ГЭЭ объектов размещения отходов».

138. Письмо Росприроднадзора от 15.11.2012 № BK-03-01-36/15437 «О направлении Методических рекомендаций по осуществлению государственного надзора за охраной атмосферного воздуха».

139. Письмо Росприроднадзора от 23.05.2013 № ВK-08-05-36/7104 «O государственной экологической экспертизе».

140. Письмо Росприроднадзора от 09.08.2013 № ВС-08-05-32/11409 «O рассмотрении обращения».

141. Письмо Росприроднадзора от 10.09.2014 № BK-03-03-36/13927 «О направлении позиции».

142. Письмо Росприроднадзора от 16.09.2014 № ОД-03-03-36/14249 «О направлении разъяснений».

143. Письмо Росприроднадзора от 22.09.2014 № ОД-02-00-36/14587 «О привлечении к административной ответственности». 
144. Письмо Госстроя России от 22.03.2013 № 1976-БМ/11/ГС «О направлении проектной документации объектов на государственную экологическую экспертизу».

145. Письмо Минрегиона России от 02.08.2012 № 20048-ИГ/17 «О направлении проектной документации для проведения государственной экспертизы и государственной экологической экспертизы».

146. Письмо Минфина РФ от 27.05.2011 № П3-7/2011 «0 бухгалтерском учете, формировании и раскрытии в бухгалтерской отчетности информации об экологической деятельности организации».

147. «ОНД 1-84. Инструкция о порядке рассмотрения, согласования и экспертизы воздухоохранных мероприятий и выдачи разрешений на выброс загрязняющих веществ в атмосферу по проектным решениям». (утв. Госкомгидрометом СССР 23.04.1984, Согласована Госстроем СССР 19.04.1984 № ВА 1878 20).

148. «Рекомендации по оформлению и содержанию проекта нормативов предельно допустимых выбросов в атмосферу (ПДВ) для предприятия» (утв. Госкомгидрометом СССР 28.08.1987).

149. «Инструкция по нормированию выбросов (сбросов) загрязняющих веществ в атмосферу и в водные объекты» (утв. Госкомприроды СССР 11.09.1989).

150. «ОНД-90. Общесоюзный нормативный документ. Руководство по контролю источников загрязнения атмосферы». (утв. Постановлением Госкомприроды СССР от 30.10.1990 № 8).

151. «Инструкция по инвентаризации выбросов загрязняющих веществ в атмосферу» (утв. Госкомприроды СССР, 1990).

152. «РД 51-1-96. Инструкция по охране окружающей среды при строительстве скважин на суше на месторождениях углеводородов поликомпонентного состава, в том числе сероводородсодержащих» (утв. Минтопэнерго России 25.01.96, Минприроды России 10.08.96).

153. «РД-17-86. Методические указания по расчету валовых выбросов вредных веществ в атмосферу для предприятий нефтепереработки и нефтехимии» (утв. Миннефтехимпромом СССР 17.02.1987).

154. «Предельное содержание токсичных соединений в промышленных отходах в накопителях, расположенных вне территории предприятия (организации)» (утв. Главным государственным санитарным врачом СССР 19.11.1985 № 4015-85, Госкомгидрометом СССР 19.11.1985, Минводхозом СССР 15.11.1985, Мингеологии СССР 18.07.1985, Минсельхозом СССР 19.06.1985).

\section{Акты органов государственной власти субъектов \\ Российской Федерации и иные акты}

155. Постановление Правительства Москвы от 27.08.2002 № 693-ПП «Об экологическом аудите».

156. Постановление Правительства Москвы от 22.07.2003 № 568-ПП «Об утверждении Временного положения о Системе экологического аудита в городе Москве, временного порядка проведения экологического аудита, крите- 
риев отнесения организаций города Москвы к числу рекомендованных для проведения экологического аудита».

157. Постановление Правительства Москвы от 20.04.2010 № 332-ПП "Об экологических требованиях к качеству и техническим характеристикам продукции, закупаемой по государственному заказу города Москвы, и направлениях совершенствования систем экологической сертификации и аудита.

158. Постановление Правительства Московской области от 24.10 .2002 № 487/42 «О проведении экологической оценки воздействия хозяйственной деятельности на окружающую среду (экологическом аудите) в Московской области.

159. Постановление Законодательного Собрания Нижегородской области от 25.03.1997 № 44 «Об утверждении Положения о государственной экологической экспертизе в Нижегородской области» (отменено).

160. Распоряжение главы муниципального образования «Балашихинский район» Московской области от 10.10.2003 № 962p «О проведении экологического аудита в Балашихинском районе».

161. Закон Амурской области от 10.11.2005 № 89-03 «Об охране окружающей среды в Амурской области».

162. Постановление Администрации Костромской области от 18.03.2011 № 81-а «Об экологическом аудите на территории Костромской области» (вместе с «Временным порядком проведения экологического аудита на территории Костромской области»).

163. Решение Государственной Думы Томской области от 29.02.1996 № 255 «О введении системы экологического аудита на территории Томской области» (вместе с «Временными правилами по проведению экологического аудита на территории Томской области»).

164. Закон Томской области от 09.10.1997 № 574 «Об экологическом аудите в Томской области».

165. Приказ Кировского областного комитета по охране природы от 05.12.1996 № 47 «Об утверждении «Временного положения об экологическом аудите в Кировской области».

166. Письмо Управления Федеральной налоговой службы по г. Москве от 15.01.2009 № 19-11/1861 «О порядке определения места реализации услуг по проведению экологического аудита».

\section{Внутренние акты российских коммерческих организаций}

167. РД 153-34.0-02.109-99 Рекомендации по проведению экологического аудита в электроэнергетике (утв. РАО «ЕС России» 05.05.1999).

168. Методика определения соответствия финансовых инструментов критериям финансирования зеленых проектов (утв. Методологическим комитетом ООО «Национальные Кредитные Рейтинги», протокол от 16.11.2020 № 25). 


\section{Международные и зарубежные правовые акты}

169. «Декларация ООН в Рио-де-Жанейро по окружающей среде и развитию» (Принята в г. Рио-де-Жанейро 14.06.1992). Ратифицирована Федеральным законом от 17.02.1995 № 16-Ф3.

170. Регламент 1221/2009 Европейского парламента и Совета ЕС о добровольном участии организаций в системе эко-менеджмента и аудита сообщества (EMAS) и об отмене Регламента (EC) 761/2001 и решений Европейской комиссии 2001/681/ЕС и 2006/193/ЕС. Страсбург, 25.11.2009.

171. Commission Implementing Decision of 09 December 2013. Establishing the best available techniques (BAT) conclusions, under Directive 2010/75/EU of the European Parliament and of the Council on industrial emissions, for the production of chlor-alkali (notified under document C(2013) 8589) (Text with EEA relevance) (2013/732/EU)

172. Commission Implementing Decision (EU) 2017/1442of 31 July 2017 establishing best available techniques (BAT) conclusions, under Directive 2010/ $75 / \mathrm{EU}$ of the European Parliament and of the Council, for large combustion plants (notified under document C(2017) 5225) (Text with EEA relevance).

173. Directive 2009/31/EU of the European Parliament and of the Council of 23 April 2009 on the geological storage of carbon dioxide and amending Council Directive 85/337/EEC, European Parliament and Council Directives 2000/60/EC, 2001/80/EC, 2004/35/EC, 2006/12/EC, 2008/1/EU and Regulation (EU) No 1013/ 2006 (Text with EEA relevance).

174. Directive 2010/75/EC of the European Parliament and of the Council of 24 November 2010 on industrial emissions (integrated pollution prevention and control) (Recast) (Text with EEA relevance) (OJ L 334 17.12.2010, p. 17).

175. Environmental Technology Verification pilot programme. Version 1.3. This document replace GVP Version 1.2 as of 1st April 2018.

176. Eco-Innovation in Finland. EIO Country Profile 2018-2019.

177. Экологический аудит в контексте финансового аудита и аудита соответствия. ИНТОСАИ - ИССАИ 5120. - 2016.

178. Handbook of International Quality Control Auditing, Review, Other Assurance, and Related Services Pronouncements. 2018 Edition. Volume 1. - International Auditingand Assurance Standard Board.: NY. - 2018. - 1146 C.

179. «Венская конвенция об охране озонового слоя» (Заключена в г. Вене 22.03.1985).

180. «Монреальский протокол по веществам, разрушающим озоновый слой» (Вместе с «Заявлениями, сделанными в момент принятия Заключительного акта Конференции полномочных представителей...", <Поправками и Корректировками к статьям 2 А, 2 В, 2 C, 2 D, 2 E, приложениям А, В, С, Е, принятыми в Лондоне 27 - 29 июня 1990 года, Копенгагене 23 - 25 ноября 1992 года, Вене 5 - 7 декабря 1995 года, Монреале 15 - 17 ноября 1997 года, Пекине 29 ноября - 3 декабря 1999 года>, <Приложением D «Список продуктов, содержащих регулируемые вещества...», принятым в Найроби 21 июня 1991 года>) (Подписан в г. Монреале 16.09.1987). 
181. «Протокол о борьбе с подкислением, эвтрофикацией и приземным озоном к Конвенции о трансграничном загрязнении воздуха на большие расстояния 1979 года» (Вместе с «Критическими нагрузками и уровнями», «Потолочными значениями выбросов», «Выделенным районом регулирования выбросов загрязнителей (РPВ3)", <Предельными значениями концентраций серы, оксидов азота, летучих органических соединений в выбросах из стационарных источников>, «Планом регулирования использования растворителей», «Схемой сокращения выбросов», «Сроками в соответствии со статьей 3», «Предельными значениями для топлив и новых мобильных источников", «Мерами по ограничению выбросов аммиака из сельскохозяйственных источников») (Подписан в г. Гетеборге 30.11.1999).

182. «Протокол об ограничении выбросов окислов азота или их трансграничных потоков к Конвенции 1979 года о трансграничном загрязнении воздуха на большие расстояния» (Подписан в г. Софии 31.10.1988).

183. «Конвенция об оценке воздействия на окружающую среду в трансграничном контексте» (Вместе с «Перечнем видов деятельности», "Содержанием документации об оценке воздействия на окружающую среду», «Общими критериями, помогающими в определении экологического значения видов деятельности...», «Процедурой запроса», «Послепроектным анализом», «Элементами... сотрудничества», «Арбитражем») (Заключена в г. Эспо 25.02.1991).

184. Соглашение стран СНГ о контроле за трансграничной перевозкой опасных и других отходов (заключено в г. Москве 12.04.1996). Утверждено постановлением Правительства РФ от 17.05.2002 № 318.

185. Модельный закон «О безопасном обращении с пестицидами и агрохимикатами" (принят в г. Санкт-Петербурге на 11-ом пленарном заседании Межпарламентской Ассамблеи государств-участников СНГ - постановление от 15.06.1998 № 11-10).

186. Модельный закон «Об отходах производства и потребления (новая редакция)» (принят в г. Санкт-Петербурге на 29-ом пленарном заседании Межпарламентской Ассамблеи государств-участников СНГ - постановлением от 31.10.2007 № 29-15).

187. Модельный закон «Об экологическом аудите» (принят на 39 пленарном заседании Межпарламентской Ассамблеи государств-участников СНГ постановление от 29.11.2013 № 39-5).

188. Экологический кодекс Республики Казахстан от 09.01.2007 № 212-III 3PK.

189. Экологический кодекс Республики Казахстан от 02.01.2021 № 400-VI 3PK.

190. Закон Республики Беларусь от 26 ноября 1992 № 1982-XII «Об охране окружающей среды».

191. Постановление Совета Министров Республики Беларусь от 26.05.2016 № 412 «Об утверждении положения о порядке проведения экологического аудита».

192. Закон Украины от 24 июня 2004 № 1862-IV «Об экологическом аудите». 


\section{Письма-разъяснения к процедуре прохождения государственной экологической экспертизы}

193. Письмо Росприроднадзора от 23.05.2013 № ВK-08-05-36/7104 «0 государственной экологической экспертизе».

194. Письмо Госстроя от 22.03.2013 № 1976-БМ/11/ГС «О направлении проектной документации объектов на государственную экологическую экспертизу».

195. Письмо Росприроднадзора от 16.04.2008 № ВK-02-30/3179 «О государственной экологической экспертизе по объектам животного мира».

196. Письмо Росприроднадзора от 21.02.2013 № ВK-03-03-36/2216 «О нарушении законодательства об экологической экспертизе при осуществлении рекультивации».

197. Письмо Минрегиона России от 02.08.2012 № 20048-ИГ/17 «О направлении проектной документации для проведения государственной экспертизы и государственной экологической экспертизы».

198. Письмо Минприроды России от 13.05.2011 № 05-12-44/7250 «0 проведении экологической экспертизы проектов технической документации на новые технику и технологию".

199. Письмо Минприроды России от 26.04.2010 № 12-47/5719 «Об оценке воздействия на окружающую среду».

200. Письмо Рослесхоза от 18.11.2009 № МГ-03-27/7219 «Об экологической экспертизе лесохозяйственных регламентов и лесного плана».

\section{Информационно-технические справочники по наилучшим доступным технологиям}

201. «ИТС 1-2015. Информационно-технический справочник по наилучшим доступным технологиям. Производство целлюлозы, древесной массы, бумаги, картона» (утв. Приказом Росстандарта от 15.12.2015 № 1571).

202. «ИТС 2-2019. Информационно-технический справочник по наилучшим доступным технологиям. Производство аммиака, минеральных удобрений и неорганических кислот» (утв. Приказом Росстандарта от 12.12.2019 № 2983).

203. «ИТС 3-2019. Информационно-технический справочник по наилучшим доступным технологиям. Производство меди» (утв. Приказом Росстандарта от 12.12.2019 № 2982).

204. «ИТС 4-2015. Производство керамических изделий».

205. «ИТС 5-2015. Производство стекла» (утв. Приказом Росстандарта от 15.12.2015 № 1575).

206. «ИТС 6-2015. Производство цемента» (утв. Приказом Росстандарта от 15.12.2015 № 1576).

207. «ИТС 7-2015. Производство извести».

208. «ИТС 8-2015. Информационно-технический справочник по наилучшим доступным технологиям. Очистка сточных вод при производстве продукции (товаров), выполнении работ и оказании услуг на крупных предприятиях» (утв. Приказом Росстандарта от 15.12.2015 № 1578). 
209. «ИТС 9-2020. Информационно-технический справочник по наилучшим доступным технологиям. Утилизация и обезвреживание отходов термическими способами» (утв. Приказом Росстандарта от 23.12.2020 № 2181).

210. «ИТС 10-2019. Очистка сточных вод с использованием централизованных систем водоотведения поселений, городских округов» (утв. Приказом Росстандарта от 12.12.2019 № 2981).

211. «ИТС 11-2019. Информационно-технический справочник по наилучшим доступным технологиям. Производство алюминия» (утв. Приказом Росстандарта от 12.12.2019 № 2980).

212. «ИТС 12-2019. Информационно-технический справочник по наилучшим доступным технологиям. Производство никеля и кобальта» (утв. Приказом Росстандарта от 12.12.2019 № 2978).

213. «ИТС 13-2016. Производство свинца, цинка и кадмия» (утв. Приказом Росстандарта от 15.12.2016 № 1889).

214. «ИТС 14-2020. Информационно-технический справочник по наилучшим доступным технологиям. Производство драгоценных металлов» (утв. Приказом Росстандарта от 23.12.2020 № 2183).

215. «ИТС 15-2016. Информационно-технический справочник по наилучшим доступным технологиям. Утилизация и обезвреживание отходов (кроме обезвреживания термическим способом (сжигание отходов)» (утв. Приказом Росстандарта от 15.12.2016 № 1887).

216. «ИТС 16-2016. Информационно-технический справочник по наилучшим доступным технологиям. Горнодобывающая промышленность. Общие процессы и методы» (утв. Приказом Росстандарта от 15.12.2016 № 1886).

217. «ИТС 17-2016. Информационно-технический справочник по наилучшим доступным технологиям. Размещение отходов производства и потребления» (утв. Приказом Росстандарта от 15.12.2016 № 1885).

218. «ИТС 18-2019. Информационно-технический справочник по наилучшим доступным технологиям. Производство основных органических химических веществ» (утв. Приказом Росстандарта от 12.12.2019 № 2979).

219. «ИТС 19-2016. Информационно-технический справочник по наилучшим доступным технологиям. Производство твердых и других неорганических химических веществ» (утв. Приказом Росстандарта от 15.12.2016 № 1883).

220. «ИТС 20-2016. Промышленные системы охлаждения» (утв. Приказом Росстандарта от 15.12.2016 № 1882).

221. «ИТС 21-2016. Информационно-технический справочник по наилучшим доступным технологиям. Производство оксида магния, гидроксида магния, хлорида магния» (утв. Приказом Росстандарта от 15.12.2016 № 1881).

222. «ИТС 22-2016. Информационно-технический справочник по наилучшим доступным технологиям. Очистка выбросов вредных (загрязняющих) веществ в атмосферный воздух при производстве продукции (товаров), а также при проведении работ и оказании услуг на крупных предприятиях» (утв. Приказом Росстандарта от 15.12.2016 № 1880). 
223. «ИТС 22.1-2016. Информационно-технический справочник по наилучшим доступным технологиям. Общие принципы производственного экологического контроля и его метрологического обеспечения» (утв. Приказом Росстандарта от 15.12.2016 № 1891).

224. «ИТС 23-2017. Информационно-технический справочник по наилучшим доступным технологиям. Добыча и обогащение руд цветных металлов» (утв. Приказом Росстандарта от 15.12.2017 № 2839).

225. «ИТС 24-2017. Информационно-технический справочник по наилучшим доступным технологиям. Производство редких и редкоземельных металлов» (утв. Приказом Росстандарта от 15.12.2017 № 2849).

226. «ИТС 25-2017. Информационно-технический справочник по наилучшим доступным технологиям. Добыча и обогащение железных руд» (утв. Приказом Росстандарта от 15.12.2017 № 2845).

227. «ИТС 26-2017. Информационно-технический справочник по наилучшим доступным технологиям. Производство чугуна, стали и ферросплавов» (утв. Приказом Росстандарта от 15.12.2017 № 2836).

228. «ИТС 27-2017. Информационно-технический справочник по наилучшим доступным технологиям. Производство изделий дальнейшего передела черных металлов» (утв. Приказом Росстандарта от 15.12.2017 № 2837).

229. «ИТС 28-2017. Информационно-технический справочник по наилучшим доступным технологиям. Добыча нефти» (утв. Приказом Росстандарта от 15.12.2017 № 2838).

230. «ИТС 29-2017. Информационно-технический справочник по наилучшим доступным технологиям. Добыча природного газа» (утв. Приказом Росстандарта от 15.12.2017 № 2844).

231. «ИТС 30-2017. Информационно-технический справочник по наилучшим доступным технологиям. Переработка нефти» (утв. Приказом Росстандарта от 14.11.2017 № 2424).

232. «ИТС 31-2017. Информационно-технический справочник по наилучшим доступным технологиям. Производство продукции тонкого органического синтеза» (утв. Приказом Росстандарта от 15.12.2017 № 2848).

233. «ИТС 32-2017. Информационно-технический справочник по наилучшим доступным технологиям. Производство полимеров, в том числе биоразлагаемых» (утв. Приказом Росстандарта от 15.12.2017 № 2843).

234. «ИТС 33-2017. Информационно-технический справочник по наилучшим доступным технологиям. Производство специальных неорганических химикатов» (утв. Приказом Росстандарта от 13.12.2017 № 2816).

235. «ИТС 34-2020. Информационно-технический справочник по наилучшим доступным технологиям. Производство прочих основных неорганических химических веществ» (утв. Приказом Росстандарта от 23.12.2020 № 2187).

236. «ИТС 35-2017. Обработка поверхностей, предметов или продукции органическими растворителями» (утв. Приказом Росстандарта от 13.12.2017 № 2817). 
237. «ИТС 36-2017. Информационно-технический справочник по наилучшим доступным технологиям. Обработка поверхностей металлов и пластмасс с использованием электролитических или химических процессов» (утв. Приказом Росстандарта от 15.12.2017 № 2842).

238. «ИТС 37-2017. Информационно-технический справочник по наилучшим доступным технологиям. Добыча и обогащение угля» (утв. Приказом Росстандарта от 15.12.2017 № 2841).

239. «ИТС 38-2017. Информационно-технический справочник по наилучшим доступным технологиям. Сжигание топлива на крупных установках в целях производства энергии» (утв. Приказом Росстандарта от 22.12.2017 № 2929).

240. «ИТС 39-2017. Информационно-технический справочник по наилучшим доступным технологиям. Производство текстильных изделий (промывка, отбеливание, мерсеризация, крашение текстильных волокон, отбеливание, крашение текстильной продукции)» (утв. Приказом Росстандарта от 15.12.2017 № 2835).

241. «ИТС 40-2017. Информационно-технический справочник по наилучшим доступным технологиям. Дубление, крашение, выделка шкур и кожи» (утв. Приказом Росстандарта от 13.12.2017 № 2818).

242. «ИТС 41-2017. Информационно-технический справочник по наилучшим доступным технологиям. Интенсивное разведение свиней» (утв. Приказом Росстандарта от 13.12.2017 № 2819).

243. «ИТС 42-2017. Информационно-технический справочник по наилучшим доступным технологиям. Интенсивное разведение сельскохозяйственной птицы» (утв. Приказом Росстандарта от 29.11.2017 № 2667).

244. «ИТС 43-2017. Информационно-технический справочник по наилучшим доступным технологиям. Убой животных на мясокомбинатах, мясохладобойнях, побочные продукты животноводства» (утв. Приказом Росстандарта от 13.12.2017 № 2820).

245. «ИТС 44-2017. Информационно-технический справочник по наилучшим доступным технологиям. Производство продуктов питания» (утв. Приказом Росстандарта от 11.12.2017 № 2784).

246. «ИТС 45-2017. Информационно-технический справочник по наилучшим доступным технологиям. Производство напитков, молока и молочной продукции» (утв. Приказом Росстандарта от 29.11.2017 № 2668).

247. «ИТС 46-2019. Информационно-технический справочник по наилучшим доступным технологиям. Сокращение выбросов загрязняющих веществ, сбросов загрязняющих веществ при хранении и складировании товаров (грузов)» (утв. Приказом Росстандарта от 17.04.2019 № 835).

248. «ИТС 47-2017. Информационно-технический справочник по наилучшим доступным технологиям. Системы обработки (обращения) со сточными водами и отходящими газами в химической промышленности" (утв. Приказом Росстандарта от 15.12.2017 № 2846).

249. «ИТС 48-2017. Информационно-технический справочник по наилучшим доступным технологиям. Повышение энергетической эффективности при 
осуществлении хозяйственной и (или) иной деятельности» (утв. Приказом Росстандарта от 29.09.2017 № 2060).

250. «ИТС 49-2017. Информационно-технический справочник по наилучшим доступным технологиям. Добыча драгоценных металлов» (утв. Приказом Росстандарта от 15.12.2017 № 2840).

251. «ИТС 50-2017. Информационно-технический справочник по наилучшим доступным технологиям. Переработка природного и попутного газа» (утв. Приказом Росстандарта от 14.11.2017 № 2423).

252. Приказ Росстандарта от 23.12.2020 № 2184 «Об утверждении информационно-технического справочника по наилучшим доступным технологиям «Производство твердых и других неорганических химических веществ».

253. Приказ Росстандарта от 23.12.2020 № 2185 «Об утверждении информационно-технического справочника по наилучшим доступным технологиям «Производство редких и редкоземельных металлов».

254. Приказ Росстандарта от 23.12.2020 № 2186 «Об утверждении информационно-технического справочника по наилучшим доступным технологиям «Производство специальных неорганических химикатов».

255. Kick-off meeting for the drawing up of the best available techniques (BAT) reference document for common waste gas treatment in the chemical sector Seville, 25 - 29 September 2017 and Interim meeting, SEVILLE 14 - 15 March 2018 Meeting report.

256. JRC science for policy report. Best Available Techniques (BAT) Reference Document for Common Waste Water and Waste Gas Treatment/Management Systems in the Chemical Sector Industrial Emissions Directive 2010/75/EU (Integrated Pollution Prevention and Control). Authors: Thomas Brinkmann German Giner Santonja Hande Yukseler Serge Roudier Luis Delgado Sancho. 2016.

257. Integrated Pollution Prevention and Control Reference Document on Economics and Cross-Media Effects July 2006.

258. Integrated Pollution Prevention and Control Reference Document on Best Available Techniques on Emissions from Storage July 2006.

259. JRC science for policy report. Best Available Techniques (BAT) Reference Document for Large Combustion Plants Industrial Emissions Directive 2010/75/ EU (Integrated Pollution Prevention and Control). Authors: Thierry Lecomte, Jose Felix Ferreria de la Fuente, Frederik Neuwahl, Michele Canova, Antoine Pinasseau, Ivan Jankov, Thomas Brinkmann, Serge Roudier, Luis Delgado Sancho. 2017.

260. JRC science for policy report. Best Available Techniques (BAT) Reference Document for Large Combustion Plants Industrial Emissions Directive 2010/75/EU (Integrated Pollution Prevention and Control). Authors: Thierry Lecomte, Jose Felix Ferreria de la Fuente, Frederik Neuwahl, Michele Canova, Antoine Pinasseau, Ivan Jankov, Thomas Brinkmann, Serge Roudier, Luis Delgado Sancho. 2017.

261. Integrated Pollution Prevention and Control Reference Document on Best Available Techniques for the Manufacture of Large Volume Inorganic Chemicals Solids and Others industry August 2007. 
262. Integrated Pollution Prevention and Control Reference Document on Best Available Techniques for the Manufacture of Organic Fine Chemicals August 2006.

263. JRC science for policy report. JRC Reference Report on Monitoring of Emissions to Air and Water from IED Installations Industrial Emissions Directive 2010/75/EU (Integrated Pollution Prevention and Control).Authors: Thomas Brinkmann, Ralf Both, Bianca Maria Scalet, Serge Roudier, Luis Delgado Sancho. 2018.

264. JRC science for policy report. Best Available Techniques (BAT) Reference Document for the Production of Large Volume Organic Chemicals Industrial Emissions Directive 2010/75/EU (Integrated Pollution Prevention and Control). Authors: HeinoFalcke, Simon Holbrook, lain Clenahan, Alfredo Lopez Carretero, TeomanSanalan, Thomas Brinkmann, Joze Roth, Benoit Zerger Serge Roudier, Luis Delgado Sancho. 2017.

265. Reference Document on Best Available Techniques in the Production of Polymers August 2007.

266. Integrated Pollution Prevention and Control Reference Document on Best Available Techniques for the Production of Speciality Inorganic Chemicals August 2007.

267. JRC science for policy report. Best Available Techniques (BAT) Reference Document for the Refining of Mineral Oil and Gas Industrial Emissions Directive 2010/75/EU (Integrated Pollution Prevention and Control). Authors: Pascal Barthe, Michel Chaugny, Serge Roudier, Luis Delgado Sancho. 2015.

268. Integrated Pollution Prevention and Control Reference Document on Best Available Techniques in the Smitheries and Foundries Industry May 2005.

269. JRC science for policy report. Best Available Techniques (BAT) Reference Document on Surface Treatment Using Organic Solvents including Preservation of Wood and Wood Products with Chemicals Industrial Emissions Directive 2010/ 75/EU (Integrated Pollution Prevention and Control). Authors: Georgios Chronopoulos, Gizem-EceCakmak, Paul Tempany, Gabriele Klein, Thomas Brinkmann, Benoit Zerger, Serge Roudier. 2020.

270. Best available technologies for manure treatment - for intensive rearing of pigs in Baltic Sea Region EU member states. Baltic Sea 2020.

\section{ГОСТы по экологии}

271. ГОСТ Р 8.589-2001 Государственная система обеспечения единства измерений. Контроль загрязнения окружающей природной среды. Метрологическое обеспечение. Основные положения.

272. ГОСТ Р 14.01-2005 Экологический менеджмент. Общие положения и объекты регулирования.

273. ГОСТ Р 14.03-2005 Экологический менеджмент. Воздействующие факторы. Классификация.

274. ГОСТ Р 14.07-2005 Экологический менеджмент. Руководство по включению аспектов безопасности окружающей среды в технические регламенты. 
275. ГОСТ P 14.08-2005 Экологический менеджмент. Порядок установления аспектов окружающей среды в стандартах на продукцию.

276. ГОСТ Р 14.11-2005 Экологический менеджмент. Общие требования к органам, проводящим оценку и сертификацию/регистрацию систем экологического менеджмента (ИСО/МЭК 66).

277. ГОСТ Р 14.12-2006 Экологический менеджмент. Интегрирование экологических аспектов в проектирование и разработку продукции.

278. ГОСТ Р 14.13-2007 Экологический менеджмент. Оценка интегрального воздействия объектов хозяйственной деятельности на окружающую среду в процессе производственного экологического контроля.

279. ГОСТ 17.0.0.01-76 Система стандартов в области охраны природы и улучшения использования природных ресурсов. Основные положения.

280. ГОСТ Р 17.0.0.06-2000 Охрана природы. Экологический паспорт природопользователя. Основные положения. Типовые формы.

281. ГОСТ 17.8.1.01-86 Охрана природы. Ландшафты. Термины и определения.

282. ГОСТ 17.8.1.02-88 Охрана природы. Ландшафты. Классификация.

283. ГОСТ Р ИСО/ТО 10217-2010 Энергия солнечная. Системы для подогрева воды. Руководство по выбору материалов с учетом внутренней коррозии.

284. ГОСТ Р ИСО 14020-99 Экологические этикетки и декларации. Основные принципы.

285. ГОСТ Р ИСО 14040-99 Управление окружающей средой. Оценка жизненного цикла. Принципы и структура.

286. ГОСТ Р ИСО 14001-2007 Системы экологического менеджмента. Требования и руководство по применению.

287. ГОСТ Р ИСО 14004-2007 Системы экологического менеджмента. Общее руководство по принципам, системам и методам обеспечения функционирования.

288. ГОСТ Р ИСО 14005-2013 Системы экологического менеджмента. Руководящие указания по поэтапному внедрению системы экологического менеджмента с использованием оценки экологической результативности.

289. ГОСТ Р ИСО 14006-2013 Системы экологического менеджмента. Руководящие указания по включению экологических норм при проектировании.

290. ГОСТ Р ИСО 14015-2007 Экологический менеджмент. Экологическая оценка участков и организаций.

291. ГОСТ Р ИСО 14020-2011 Этикетки и декларации экологические. Основные принципы.

292. ГОСТ Р ИСО 14021-2000 Этикетки и декларации экологические. Самодекларируемые экологические заявления (экологическая маркировка по типу II).

293. ГОСТ Р ИСО 14024-2000 Этикетки и декларации экологические. Экологическая маркировка типа І. Принципы и процедуры. 
294. ГОСТ Р ИСО 14025-2012 Этикетки и декларации экологические. Экологические декларации типа III. Принципы и процедуры.

295. ГОСТ Р ИСО 14040-2010 Экологический менеджмент. Оценка жизненного цикла. Принципы и структура.

296. ГОСТ Р ИСО 14042-2001 Управление окружающей средой. Оценка жизненного цикла. Оценка воздействия жизненного цикла.

297. ГОСТ Р ИСО 14043-2001 Управление окружающей средой. Оценка жизненного цикла. Интерпретация жизненного цикла.

298. ГОСТ Р ИСО 14044-2007 Экологический менеджмент. Оценка жизненного цикла. Требования и рекомендации.

299. ГОСТ Р ИСО/ТС 14048-2009 Экологический менеджмент. Оценка жизненного цикла. Формат документирования данных.

300. ГОСТ Р ИСО 14050-2009 Менеджмент окружающей среды. Словарь.

301. ГОСТ Р ИСО 14051-2014 Экологический менеджмент. Учет затрат на материальные потоки. Общие принципы.

302. ГОСТ Р ИСО 14063-2007 Экологический менеджмент. Обмен экологической информацией. Рекомендации и примеры.

303. ГОСТ Р ИСО 14065-2010 Газы парниковые. Требования к органам по валидации и верификации парниковых газов для их применения при аккредитации или других формах признания.

304. ГОСТ ИСО 14123-1-2000 Безопасность оборудования. Снижение риска для здоровья от опасных веществ, выделяемых оборудованием. Часть 1. Основные положения и технические требования.

305. ГОСТ ИСО 14123-2-2001 Безопасность оборудования. Снижение риска для здоровья от опасных веществ, выделяемых оборудованием. Часть 2. Методика выбора методов проверки.

306. ГОСТ Р ИСО 14644-2-2001 Чистые помещения и связанные с ними контролируемые среды. Часть 2. Требования к контролю и мониторингу для подтверждения постоянного соответствия ГОСТ Р ИСО 14644-1-2000.

307. ГОСТ Р ИСО 14644-4-2002 Чистые помещения и связанные с ними контролируемые среды. Часть 4. Проектирование, строительство и ввод в эксплуатацию.

308. ГОСТ Р ИСО 19011-2003 Руководящие указания по аудиту систем менеджмента качества и/или систем экологического менеджмента.

309. ГОСТ 32290-2013 Методы испытаний химической продукции, представляющей опасность для окружающей среды. Определение биоразлагаемости по угнетению потребления кислорода активным илом.

310. ГОСТ 32292-2013 Методы испытаний химической продукции, представляющей опасность для окружающей среды. Определение токсичности для мальков рыб.

311. ГОСТ 32293-2013 Методы испытаний химической продукции, представляющей опасность для окружающей среды. Испытание водорослей и цианобактерий на задержку роста. 
312. ГОСТ 32294-2013 Методы испытаний химической продукции, представляющей опасность для окружающей среды. Определение токсичности для рыб на ранних стадиях развития.

313. ГОСТ 32367-2013 Методы испытаний химической продукции, представляющей опасность для окружающей среды. Угнетение репродуктивной способности Дафнии магна.

314. ГОСТ 32368-2013 Методы испытаний химической продукции, представляющей опасность для окружающей среды. Оценка репродуктивной способности рыб.

315. ГОСТ 32369-2013 Методы испытаний химической продукции, представляющей опасность для окружающей среды. Оценка биоразлагаемости в аэробных условиях методом моделирования поверхностных вод.

316. ГОСТ 32370-2013 Методы испытаний химической продукции, представляющей опасность для окружающей среды. Оценка биоразлагаемости методом моделирования сточных вод.

317. ГОСТ 32424-2013 Классификация опасности химической продукции по воздействию на окружающую среду. Основные положения.

318. ГОСТ 32425-2013 Классификация опасности смесевой химической продукции по воздействию на окружающую среду.

319. ГОСТ 32426-2013 Методы испытаний химической продукции, представляющей опасность для окружающей среды. Испытание ряски на угнетение роста.

320. ГОСТ 32427-2013 Методы испытаний химической продукции, представляющей опасность для окружающей среды. Определение биоразлагаемости. 28-дневный тест.

321. ГОСТ 32428-2013 Методы испытаний химической продукции, представляющей опасность для окружающей среды. Определение хронической токсичности для рыб: 14-дневный тест.

322. ГОСТ 32432-2013 Методы испытаний химической продукции, представляющей опасность для окружающей среды. Аэробные и анаэробные трансформации в донных отложениях.

323. ГОСТ 32433-2013 Методы испытаний химической продукции, представляющей опасность для окружающей среды. Оценка биоразлагаемости органических соединений методом определения диоксида углерода в закрытом сосуде.

324. ГОСТ 32434-2013 Методы испытаний химической продукции, представляющей опасность для окружающей среды. Фотопревращение химических веществ в воде. Прямой фотолиз.

325. ГОСТ 32473-2013 Методы испытаний химической продукции, представляющей опасность для окружающей среды. Определение острой токсичности для рыб.

326. ГОСТ 32475-2013 Методы испытаний химической продукции, представляющей опасность для окружающей среды. Оценка биоразлагаемости органических соединений в сброженном осадке сточных вод в анаэробных условиях. 
327. ГОСТ 32477-2013 Методы испытаний химической продукции, представляющей опасность для окружающей среды. Определение биоаккумуляции на придонных малощетинковых червях.

328. ГОСТ 32536-2013 Методы испытаний химической продукции, представляющей опасность для окружающей среды. Определение острой токсичности для дафний.

329. ГОСТ 32537-2013 Методы испытаний химической продукции, представляющей опасность для окружающей среды. Определение биоразлагаемости при аэробных методах очистки.

330. ГОСТ 32538-2013 Методы испытаний химической продукции, представляющей опасность для окружающей среды. Определение биоконцентрации на рыбах в проточных аквариумах.

331. ГОСТ 32541-2013 Методы испытаний химической продукции, представляющей опасность для окружающей среды. Краткосрочное испытание токсичности на эмбрионах и предличинках рыб.

332. ГОСТ 33038-2014 Методы испытаний химической продукции, представляющей опасность для окружающей среды. Пчелы медоносные: тест на острую пероральную токсичность.

333. ГОСТ 33039-2014 Методы испытаний химической продукции, представляющей опасность для окружающей среды. Пчелы медоносные: тест на острую контактную токсичность.

334. ГОСТ 33061-2014 Методы испытаний химической продукции, представляющей опасность для окружающей среды. Наземные растения: тест на всхожесть семян и развитие проростков.

335. ГОСТ Р 51074-2003 Продукты пищевые. Информация для потребителя. Общие требования.

336. ГОСТ Р 51956-2002 Экологические этикетки и декларации. Экологические декларации типа III.

337. ГОСТ Р 52106-2003 Ресурсосбережение. Общие положения.

338. ГОСТ Р 52174-2003 Биологическая безопасность. Сырье и продукты пищевые. Метод идентификации генетически модифицированных источников (ГМИ) растительного происхождения с применением биологического микрочипа.

339. ГОСТ Р 52724-2007 Системы управления окружающей средой. Общие руководящие указания по созданию, внедрению и обеспечению функционирования на объектах по уничтожению химического оружия.

340. ГОСТ Р 52724-2010 Системы экологического менеджмента. Общие руководящие указания по созданию, внедрению и обеспечению функционирования на объектах по уничтожению химического оружия.

341. ГОСТ Р 52985-2008 Экологическая безопасность ракетно-космической техники. Общие технические требования.

342. ГОСТ Р 53009-2008 Системы экологического контроля и мониторинга. Общие руководящие указания по созданию, внедрению и обеспечению функционирования на объектах по уничтожению химического оружия. 
343. ГОСТ Р 53054-2008 Машинные технологии производства продукции растениеводства. Методы экологической оценки.

344. ГОСТ Р 53719-2009 (ЕН 14182:2002) Ресурсосбережение. Упаковка. Термины и определения.

345. ГОСТ P 53740-2009 (ЕН 13428:2004) Ресурсосбережение. Упаковка. Специальные требования к минимизации, составу, изготовлению упаковки.

346. ГОСТ Р 53741-2009 (ЕН 13431:2004) Ресурсосбережение. Упаковка. Требования к отработавшей упаковке для ее переработки в качестве вторичных энергетических ресурсов.

347. ГОСТ Р 53742-2009 (ЕН 13430:2004) Ресурсосбережение. Упаковка. Требования к отработавшей упаковке для ее переработки в качестве вторичных материальных ресурсов.

348. ГОСТ Р 53744-2009 (ЕН 13427:2004) Ресурсосбережение. Упаковка. Требования к применению европейских стандартов в области упаковки и упаковочных отходов.

349. ГОСТ Р 53754-2009 (ЕН 13440:2003) Ресурсосбережение. Упаковка. Показатели и методы расчета результативности переработки отработавшей упаковки в качестве вторичных материальных ресурсов.

350. ГОСТ P 53756-2009 (ЕН 13437:2003) Ресурсосбережение. Упаковка. Критерии выбора методов и процессов переработки отработавшей упаковки в качестве вторичных материальных ресурсов с учетом материальных потоков.

351. ГОСТ Р 53759-2009 (ЕН 13429:2004) Ресурсосбережение. Упаковка. Повторное использование.

352. ГОСТ P 53790-2010 Нетрадиционные технологии. Энергетика биоотходов. Общие технические требования к биогазовым установкам.

353. ГОСТ P 53791-2010 Ресурсосбережение. Стадии жизненного цикла изделий производственно-технического назначения. Общие положения.

354. ГОСТ Р 54003-2010 Экологический менеджмент. Оценка прошлого накопленного в местах дислокации организаций экологического ущерба. Общие положения.

355. ГОСТ Р 54097-2010 Ресурсосбережение. Наилучшие доступные технологии. Методология идентификации.

356. ГОСТ Р 54298-2010 Системы экологического менеджмента. Порядок сертификации систем экологического менеджмента на соответствие ГОСТ Р ИCO 14001-2007.

357. ГОСТ P 54318-2011 Порядок определения продолжительности сертификации систем менеджмента качества и систем экологического менеджмента. Общие требования.

358. ГОСТ P 54336-2011 Системы экологического менеджмента в организациях, выпускающих нанопродукцию. Требования.

359. ГОСТ Р 54906-2012 Системы безопасности комплексные. Экологически ориентированное проектирование. Общие технические требования.

360. ГОСТ Р 54964-2012 Оценка соответствия. Экологические требования к объектам недвижимости. 
361. ГОСТ Р 55267-2012 Системы экологического менеджмента. Рекомендации по применению при разработке и освоении инновационной продукции.

362. ГОСТ Р 55568-2013 Оценка соответствия. Порядок сертификации систем менеджмента качества и систем экологического менеджмента.

363. ГОСТ Р 55654-2013 (ИСО 16813:2006) Проектирование зданий с учетом экологических требований. Внутренняя среда. Общие принципы.

364. ГОСТ P 55833-2013 Ресурсосбережение. Требования к документированию при производстве продукции. Политика рационального использования и экономии материалов.

365. ГОСТ P 55834-2013 Ресурсосбережение. Требования к документированию при производстве продукции. Экологическая политика предприятия.

366. ГОСТ Р 56020-2014 Бережливое производство. Основные положения и словарь.

367. ГОСТ Р 56059-2014 Производственный экологический мониторинг. Общие положения.

368. ГОСТ Р 56061-2014 Производственный экологический контроль. Требования к программе производственного экологического контроля.

369. ГОСТ Р 56062-2014 Производственный экологический контроль. Общие положения.

370. ГОСТ Р 56063-2014 Производственный экологический мониторинг. Требования к программам производственного экологического мониторинга.

371. ГОСТ Р 56257-2014 Характеристика факторов внешнего природного воздействия. Общая классификация.

372. ГОСТ Р 56258-2014 Менеджмент загрязнений. Термины и определения.

373. ГОСТ Р 56259-2014 Надлежащая практика регулирования. Руководство по ограничению воздействия промышленных предприятий на окружающую среду.

374. ГОСТ Р 56260-2014 Стратегическое развитие. Надлежащая практика регулирования. Руководство по надлежащей практике в области экологического менеджмента.

375. ГОСТ P 56268-2014/ISO Guide 64:2008 Руководство по включению экологических аспектов в стандарты на продукцию.

376. ГОСТ P 56270-2014/ISO/TR 14049:2012 Экологический менеджмент. Оценка жизненного цикла. Примеры использования ИСО 14044 для определения цели, области исследования и инвентаризационных анализов.

377. ОСТ 153-34.0-02-021-99 Охрана природы. Атмосфера. Тепловая энергетика. Термины и определения.

378. Р 50-601-22-92 Рекомендации. Установление требований экологичности продукции в стандартах и технических условиях.

379. ГОСТ Р ИСО 14010-98 «Руководящие указания по экологическому аудиту. Основные принципы»(отменен). 
380. ГОСТ Р ИСО 14011-98 Руководящие указания по экологическому аудиту. Процедуры аудита. Проведение аудита систем управления окружающей средой (отменен).

381. ГОСТ Р ИСО 14012-98 Руководящие указания по экологическому аудиту. Квалификационные критерии для аудиторов в области экологии (отменен).

382. ГОСТ Р ИСО 14034-2016 Экологический менеджмент. Верификация технологий защиты окружающей среды (отменен).

383. ГОСТ Р ИСО 10011-1-93 «Руководящие указания по проверке систем качества. Часть 1. Проверка» (отменен).

384. ГОСТ Р ИСО 10011-2-93 «Руководящие указания по проверке систем качества. Часть 2. Квалификационные критерии для экспертов-аудиторов» (отменен).

385. ГОСТ Р ИСО 10011-3-93 «Руководящие указания по проверке систем качества. Часть 3. Руководство программой проверок» (отменен).

386. СДА-20-2010 Руководство по применению стандарта ГОСТ Р ИСО/ МЭК 17021-2012 «Оценка соответствия требованиям к органам, проводящим аудит и сертификацию систем менеджмента» в области промышленной, экологической безопасности, безопасности в энергетике и строительстве. Принято Наблюдательным советом, реш. от 25.01.2010 № 33-БНС.

\section{Судебные решения}

387. Решение Верховного Суда РФ от 15.10.2015 № АКПИ15-863.

388. Постановление Федерального арбитражного суда Уральского округа от 11.05.2010 № Ф09-3146/10-С3 по делу № А60-35758/2009.

389. Постановление Арбитражного суда Уральского округа от 26.08.2020 № Ф09-6943/06 по делу № А50-43610/2005.

\section{Литература}

390. Аналитическая записка «Система надзора и контроля за экологическими рисками в Российской Федерации». НИР 20 «Выявление, оценка и управление экологическими рисками при реализации инвестиционных проектов в Российской Федерации - текущее положение и перспективы». - Москва: ФГБОУ «НИФИ». - 2018. - 24 с.

391. Дерябин, В.А. Экология: учебное пособие / В.А. Дерябин, Е.П. Фарафонтова.- Екатеринбург: Изд-во Урал.ун-та, 2016.- 136 с.

392. Зеленые финансы: повестка дня для России. Диагностическая записка. // Экспертный совет по рынку долгосрочных инвестиций при Банке России. Рабочая группа по вопросам ответственного финансирования (ESG-finance), в т.ч. «зеленого» финансирования. - Москва, октябрь 2018. $-63 \mathrm{c}$.

393. Иутин И.Г. Экологический аудит: роль, сущность и вопросы, требующие правового регулирования // Журнал российского права. - 2008. - № 2. c. $94 \mathrm{a}-101$. 
394. Иутин И.Г. Экологический аудит: роль, сущность и проблемы правового регулирования // Государство и право. - 2008. - № 4. - с. 108-112.

395. Концепция организации в России методологической системы по развитию зеленых финансовых инструментов и проектов ответственного финансирования. // Экспертный совет по рынку долгосрочных инвестиций при Банке России. Рабочая группа по вопросам ответственного финансирования (ESGfinance). - Москва. - 2019. - 87 с.

396. Крассов О.И. Экологическое право: учебник / под ред. Лисицына О.А. - 4-е изд. - М.: издательство «Норма», 2018. - 528 с.

397. Международное экологическое право: учебник / под ред. Р.М. Валеева. -2-е изд. - М.: издательство Проспект, 2020. - 680 с.

398. Саркисов, О.Р. Экологическое право: учеб. пособие для студ. учреждений высшего проф. образования / О.Р.Саркисов, Е.Л. Любарский. -5-е изд. переработанное и доп - Казань: Центр инновационных технологий, 2014. $335 \mathrm{c}$.

399. Сергиенко О.И., Суворова Ю.С., Федюшина Т.А. Технологический банчмаркинг для идентификации наилучших доступных технологий: сравнительный анализ европейского и российского опыта // Научный журнал НИУ ИТМО. Серия «Экономика и экологический менеджмент». - 2015. - № 3. - с. 414428.

400. Струкова М.Н. Экологический менеджмент и аудит: учебное пособие / М.Н. Струкова, Л.В. Струкова. - Екатеринбург: Изд-во Урал. федер. ун-т, 2016. -80 c.

401. Тимошенко Ю.А. Ответственность за экологические преступления. Теория и практика. Научно-практический комментарий к постановлениям пленума ВС РФ. - М.: издательство Проспект, 2017. - 240 с.

402. Тюльпанов Ф.М. Экологическое право: учебник / Ф.М. Тюльпанов. Москва: ЮСТИЦИЯ, 2018. - 534 с.

403. Чуйкова Л.Ю. Экологический аудит (курс лекций) // Астраханский вестник экологического образования. - 2011. - № 1 (17). - с. 120-144.

404. Шевелева А.В., Тяглов С.Г. Практика внедрения наилучших доступных технологий в нефтегазовом комплексе России // Journal of Economic Regulation (Вопросы регулирования экономики). - 2018. -Vol. 9. - № 4. - с. 63-71

405. Экологическое право: учебник для бакалавриата и специалитета / C. А. Боголюбов [и др.]; под ред. С. А. Боголюбова. - 7-е изд., перераб. и доп. М.: Издательство Юрайт, 2019. - 304 с.

406. Экология: учебник / под ред. Е.В. Титова. - 7-е изд. - М.: Академия, 2019. - 208 c.

407. Environmental Auditing. Integrated Environmental Management Information Series. 14. Department of Environmental Affairs and Tourism. SouthAfrica. - $16 \mathrm{c}$. 


\section{Источники в сети Интернет}

408. http://www.eippcb.jrc.ec.europa.eu

409. http://www.equator-principles.com

410. http://www.ecopalata.ru

411. https://www.centrinvest.ru/files/en-reports/env-report-2019.pdf

412. https://www.surgutneftegas.ru/upload/iblock/06c/ECO\%202019\%20rus.pdf

413. http://sr2012.alrosa.ru/assets/files/al_a4_full_16_PRINT.pdf 


\section{ПРИЛОЖЕНИЯ}

Приложение № 1

Документ предоставлен КонсультантПлюс

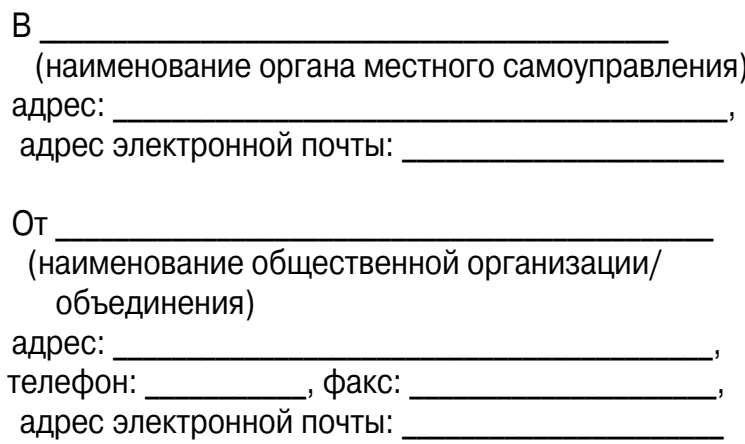

Заявление

о проведении общественной экологической экспертизы

Общественная организация (объединение) гистрированная по адресу: , зареправлению деятельности которой относится охрана окружающей среды ${ }^{1}$, в соответствии со ст. 20Федерального закона от 23.11.1995 № 174-Ф3 «Об экологической экспертизе ”² вносит предложение о проведении общественной экологической экспертизы, объектом которой является

\footnotetext{
${ }^{1}$ Согласно абз. 10 п. 1 ст. 12 Федерального закона от 10.01.2002 № 7-Ф3 «Об охране окружающей среды» общественные объединения и некоммерческие организации имеют право организовывать и проводить в установленном порядке общественную экологическую экспертизу.

${ }^{2}$ Согласно ст. 20 Федерального закона от 23.11.1995 № 174-ФЗ «Об экологической экспертизе» общественная экологическая экспертиза организуется и проводится по инициативе граждан и общественных организаций (объединений), а также по инициативе органов местного самоуправления общественными организациями (объединениями), основным направлением деятельности которых в соответствии с их уставами является охрана окружающей среды, в том числе организация и проведение экологической экспертизы, и которые зарегистрированы в порядке, установленном законодательством Российской Федерации.
} 
(указать сведения об объекте общественной эко-

логической экспертизы).

Состав экспертной комиссии общественной экологической экспертизы:

Сроки проведения общественной экологической экспертизы: с "г. по «"” $\Gamma$.

Приложение:

1. Копия устава заявителя и других документов, подтверждающих наличие оснований для проведения экологической экспертизы.

2. Копия документа, подтверждающего факт внесения сведений о заявителе в Единый государственный реестр юридических лиц.

3. Выписка из Единого государственного реестра юридических лиц или Единого государственного реестра индивидуальных предпринимателей с указанием сведений о месте нахождения заявителя или иной документ, подтверждающий указанные сведения или отсутствие таковых.

4. Доверенность представителя от “_” г. №

5. Иные документы, подтверждающие обстоятельства, на которых заявитель основывает свои предложения.

"- " $\Gamma$.

Заявитель (представитель): (подпись) / (Ф.И.О.) 
Приложение № 2

Документ предоставлен КонсультантПлюс

(наименование, юридический адрес, телефон, факс, адрес электронной почты общественного объединения)

\section{Извещение}

о начале проведения экологической экспертизы

ведущее деятельность по

(наименование общественного объединения)

(указать характер уставной деятельности)

организует общественную экологическую экспертизу, и в соответствии с п. 4 ст. 23, ст. 14 Федерального закона от 23.11.1995 № 174-Ф3 «Об экологической экспертизе» извещает жителей

(указать территорию, район)

о том, что с «— $\Gamma$.

начинается проведение общественной экологической экспертизы

$$
\text { (указать данные проекта/объекта) }
$$

в порядке, установленном ст. 22 Федерального закона от 23.11.1995 № 174-Ф3 «Об экологической экспертизе».

С описанием проекта (объекта), а также с представленными на экспертизу материалами и документами можно ознакомиться по адресу: и в сети Интернет по адресу:

В состав экспертной комиссии общественной экологической экспертизы входят:

Срок проведения указанной общественной экологической экспертизы составляет месяцев.

Обоснованные мнения, предложения, замечания принимаются по электронной почте: и по адресу:

$\ll$ $\Gamma$.

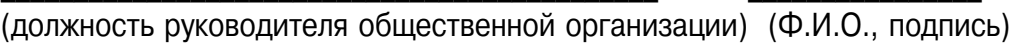


Приложение № 3

Документ предоставлен КонсультантПлюс

(бланк и (или) наименование, адрес, телефон, факс, адрес электроннойпочты общественного объединения)

ИЗВЕЩЕНИЕ ${ }^{1}$

о результатах проведения экологической экспертизы

(наименование общественной организации (объединения)

в период с “ Г.п० « г. проводилась общественная экологическая экспертиза

$$
\text { (указать объект) }
$$

Общественная экологическая экспертиза проводилась в порядке, установленном ст. 22 Федерального закона от 23.11.1995 № 174-ФЗ «Об экологической экспертизе».

С описанием проекта (объекта), с представленными на экспертизу материалами и документами, а также с результатами экспертизы можно ознакомиться по адресу: и на сайте в сети «Интернет» по адресу:

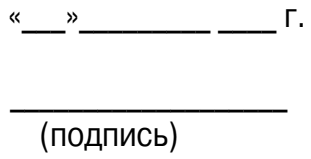

${ }^{1}$ В соответствии с п. 4 ст. 23 Федерального закона от 23.11.1995 № 174Ф3 «Об экологической экспертизе» общественные организации (объединения), организующие общественную экологическую экспертизу, обязаны известить население о начале и результатах ее проведения. 
Приложение № 4

Проект

\title{
РОССИЙСКАЯ ФЕДЕРАЦИЯ
}

\author{
ФЕДЕРАЛЬНЫЙ ЗАКОН
}

\section{ОБ ЭКОЛОГИЧЕСКОМ АУДИТЕ И ЭКОЛОГИЧЕСКОЙ АУДИТОРСКОЙ ДЕЯТЕЛЬНОСТИ}

\section{Статья 1. Основные понятия}

Для целей настоящего Федерального закона используются следующие понятия:

экологическая аудиторская деятельность - деятельность по проведению экологического аудита, осуществляемая экологическими аудиторскими организациями, индивидуальными экологическими аудиторами, имеющими лицензию на осуществление экологической аудиторской деятельности;

экологический аудит - независимая, комплексная, документированная оценка соблюдения юридическим лицом или индивидуальным предпринимателем требований, в том числе нормативов и нормативных документов, федеральных норм и правил, в области охраны окружающей среды и подготовка рекомендаций по улучшению такой деятельности;

экологический аудитор - физическое лицо, получившее квалификационный аттестат экологического аудитора и являющееся членом одной из экологической аудиторской организации или физическое лицо, получившее квалификационный аттестат аудитора и осуществляющее экологическую аудиторскую деятельность в качестве индивидуального экологического аудитора;

экологическая аудиторская организация - юридическое лицо, имеющее лицензию на осуществление экологической аудиторской деятельности;

индивидуальный экологический аудитор - индивидуальный предприниматель, получивший квалификационный аттестат экологического аудитора и имеющий лицензию на осуществление экологической аудиторской деятельности;

аудируемое лицо - юридическое лицо или индивидуальный предприниматель, в отношении которого проводится экологический аудит;

заказчик экологического аудита - аудируемое лицо, юридическое или физическое лицо, являющееся его учредителем, собственник иму216 
щества аудируемого лица, арбитражный управляющий, органы государственной власти или местного самоуправления, уполномоченные на приватизацию государственного или муниципального имущества, заключившие договор на оказание услуг по проведению экологического аудита;

документы в области охраны окружающей среды - разрешительные, отчетные, проектные и иные нормативные документы в области охраны окружающей среды, на основании которых допускается осуществление хозяйственной и (или) иной деятельности, наличие которых является обязательным в соответствии с законодательством в области охраны окружающей среды;

заключение экологического аудита - официальный документ, содержащий мнение экологической аудиторской организации, индивидуального экологического аудитора о соответствии/несоответствии объекта экологического аудита требованиям в области охраны окружающей среды, составленный и оформленный в соответствии с требованиями, установленными настоящим Федеральным законом и федеральными правилами экологической аудиторской деятельности;

заведомо ложное заключение экологического аудита - заключение экологического аудита, составленное без проведения экологического аудита или составленное по результатам экологического аудита, но явно противоречащее документам в области охраны окружающей среды, рассматриваемых экологической аудиторской организацией, индивидуальным экологическим аудитором в ходе экологического аудита. Заведомо ложным заключение экологического аудита признается по решению суда.

\section{Статья 2. Правовое регулирование отношений в области экологической аудиторской деятельности}

1. Отношения в области экологической аудиторской деятельности регулируются настоящим Федеральным законом, законодательством в области охраны окружающей среды, другими федеральными законами, а также принимаемыми в соответствии с ними иными нормативными правовыми актами Российской Федерации, законами и иными нормативными правовыми актами субъектов Российской Федерации не противоречащими Федеральным законам.

2. Требования к порядку осуществления экологической аудиторской деятельности и процедурам проведения экологического аудита определяются федеральными правилами экологической аудиторской деятельности, утверждаемыми Правительством Российской Федерации.

3. Отношения между индивидуальным экологическим аудитором, экологической аудиторской организацией и аудируемым лицом регулиру- 
ются договором на оказание услуг по проведению экологического аудита, заключаемым в соответствии с Гражданским кодексом Российской Федерации.

\section{Статья 3. Цели и принципы экологического аудита}

1. Экологический аудит осуществляется в целях выявления и предотвращения нарушения требований в области охраны окружающей среды, обеспечения выполнения мероприятий по снижению негативного воздействия хозяйственной и (или) иной деятельности на окружающую среду и ликвидации последствий негативного воздействия на окружающую среду.

2. Экологический аудит осуществляется в соответствии со следующими принципами:

независимость экологических аудиторских организаций, индивидуальных экологических аудиторов;

беспристрастность экологических аудиторов, что подразумевает объективное и непредвзятое выполнение действий по оценке соблюдения требований в области охраны окружающей среды, а также не допущение любого коммерческого, финансового и иного давления;

обеспечение конфиденциальности сведений, полученных в процессе осуществления экологического аудита и составляющих государственную, коммерческую, иную охраняемую законом тайну, и использование таких сведений только в целях, для которых они предоставлены;

недопустимость ограничения конкуренции и создания препятствий для пользования услугами экологических аудиторских организаций, индивидуальных экологических аудиторов.

3. Проведение лабораторных исследований и испытаний в рамках экологического аудита осуществляется государственными учреждениями, подведомственными федеральному органу исполнительной власти, уполномоченному на осуществление федерального государственного экологического надзора, аккредитованными в соответствии с законодательством Российской Федерации об аккредитации в национальной системе аккредитации.

\section{Статья 4. Объекты, субъекты экологического аудита}

1. Объектами экологического аудита являются:

1) хозяйственная и (или) иная деятельность юридических лиц и индивидуальных предпринимателей, оказывающая негативное воздействие на окружающую среду;

2) документы в области охраны окружающей среды;

3) имущество, используемое юридическими лицами или индивидуальными предпринимателями в целях осуществления хозяйственной и 
(или) иной деятельности юридических лиц и индивидуальных предпринимателей, на объекте, оказывающем негативное воздействие на окружающую среду.

2. Субъектами экологического аудита являются:

экологический аудитор;

аудируемое лицо;

заказчик экологического аудита.

3. Положения настоящего Федерального закона, регулирующие деятельность экологических аудиторских организаций, применяются также к индивидуальным экологическим аудиторам, если иное не предусмотрено настоящим Федеральным законом.

\section{Статья 5. Обязательный экологический аудит}

1. Обязательный экологический аудит проводится в случаях:

1) осуществления лицензируемых видов деятельности по обращению с отходами I - III классов опасности;

2) осуществления деятельности по утилизации, размещению и обезвреживанию отходов IV - V классов опасности на объектах, оказывающих негативное воздействие на окружающую среду, I и II категории;

3) реализации проекта восстановительных работ в целях возмещения вреда окружающей среде, причиненного нарушением законодательства в области охраны окружающей среды, на основании решения суда;

4) выполнения мероприятий специальных экологических программ реабилитации радиационно загрязненных участков территории;

5) принятия решения о признании должника банкротом и об открытии конкурсного производства в отношении должника, признанного банкротом и осуществлявшего деятельность на объектах, оказывающих негативное воздействие на окружающую среду, I и II категории;

6) принятия решения о приватизации объектов, оказывающих негативное воздействие на окружающую среду, I и II категории.

2. Обязательный экологический аудит проводится:

1) в случае, предусмотренном пунктами 1 и 2 части 1 настоящей статьи, - один раз в три года;

2) в случае, предусмотренном пунктом 3 части 1 настоящей статьи, - не позднее шести месяцев после окончания реализации проекта восстановительных работ в целях возмещения вреда окружающей среде, причиненного нарушением законодательства в области охраны окружающей среды;

3) в случае, предусмотренном пунктом 4 части 1 настоящей статьи, - не позднее шести месяцев после выполнения мероприятия специальной экологической программы реабилитации радиационно загрязненных участков территории; 
4) в случае, предусмотренном пунктом 5 части 1 настоящей статьи, - на этапе открытия конкурсного производства, в соответствии с требованиями, установленными Федеральным законом от 26.10.2002 N 127Ф3 (ред. от 31.07.2020) «О несостоятельности (банкротстве)» (с изм. и доп., вступ. в силу с 01.09.2020);

5) в случае, предусмотренном пунктом 6 части 1 настоящей статьи, - на этапе информационного обеспечения приватизации государственного или муниципального имущества, в соответствии с требованиями, установленными Федеральным законом от 21.12.2001 N 178-ФЗ (ред. от 31.07.2020) «О приватизации государственного и муниципального имущества».

3. В рамках обязательного экологического аудита:

1) в случае, предусмотренном пунктом 1 части первой настоящей статьи, - проводится оценка соответствия хозяйственной и (или) иной деятельности, документов в области охраны окружающей среды аудируемого лица требованиям в области охраны окружающей среды в части обращения с отходами I - III классов опасности;

2) в случае, предусмотренном пунктом 2 части первой настоящей статьи, - проводится оценка соответствия хозяйственной и (или) иной деятельности, документов в области охраны окружающей среды аудируемого лица требованиям в области охраны окружающей среды в части утилизации, размещения и обезвреживания отходов IV - V классов опасности;

3) в случае, предусмотренном пунктом 3 части первой настоящей статьи, - проводится оценка соответствия отчета о выполнении проекта восстановительных работ и результатов выполнения мероприятий указанного проекта требованиям в области охраны окружающей среды в части возмещения вреда окружающей среде;

4) в случае, предусмотренном пунктом 4 части первой настоящей статьи, - проводится оценка соответствия отчета о выполнении мероприятий специальных экологических программ радиационно загрязненных участков территории и результатов выполнения мероприятий указанных программ требованиям в области охраны окружающей среды, включая радиационного воздействия, в части реабилитации радиационно загрязненных участков территории;

5) в случае, предусмотренном пунктом 5 части первой настоящей статьи, - проводится оценка соответствия имущества и документов в области охраны окружающей среды должника требованиям в области в охраны окружающей среды в части наличия задолженностей по плате за негативное воздействие на окружающую среду, обязанности восстановления нарушенного состояния окружающей среды в результате деятельности указанного объекта; 
6) в случае, предусмотренном пунктом 6 части первой настоящей статьи, - проводится оценка имущества, подлежащего приватизации, и документов в области охраны окружающей среды требованиям в области охраны окружающей среды в части наличия задолженностей по плате за негативное воздействие на окружающую среду, обязанности восстановления нарушенного состояния окружающей среды в результате деятельности указанного объекта.

4. Копия заключения экологического аудита по результатам проведения обязательного экологического аудита направляется заказчиком экологического аудита в соответствии с законодательством Российской Федерации в течение 10 календарных дней со дня утверждения заключения экологического аудита:

1) в случаях, предусмотренных пунктами 1 - 4 части 1 настоящей статьи, - в уполномоченные федеральные органы исполнительной власти Российской Федерации или органы исполнительной власти субъекта Российской Федерации;

2) в случае, предусмотренном пунктом 5 части 1 настоящей статьи, - арбитражному управляющему;

3) в случае, предусмотренном пунктом 6 части 1 настоящей статьи, - в федеральные органы исполнительной власти Российской Федерации, органы исполнительной власти субъекта Российской Федерации, органы местного самоуправления, уполномоченные на принятие решения о приватизации государственного или муниципального имущества.

5. Юридические лица, индивидуальные предприниматели несут ответственность за невыполнение требований об обязательном экологическом аудите в соответствии с законодательством Российской Федерации.

\section{Статья 6. Добровольный экологический аудит}

1. Добровольный экологический аудит проводится по инициативе заказчика экологического аудита.

2. Добровольный экологический аудит может быть:

комплексным аудитом;

технологическим аудитом.

3. При проведении комплексного аудита осуществляется оценка соответствия хозяйственной и (или) иной деятельности, документов в области охраны окружающей среды, иных объектов аудируемого лица требованиям в области охраны окружающей среды в части рационального использования и охраны недр, использования и охраны земель, обращения с отходами, охраны атмосферного воздуха, использования и охраны водных объектов, особо охраняемых природных территорий, государственной экологической экспертизы. 
Заключение комплексного аудита рассматривается в качестве заключения обязательного экологического аудита в случае осуществления деятельности, предусмотренном частями 1 и 2 статьи 5 настоящего Федерального закона.

4. Наряду с установленными частью 3 настоящей статьи требованиями может проводиться оценка соответствия хозяйственной и (или) иной деятельности, документов в области охраны окружающей среды, иных объектов аудируемого лица требованиям, определенным в договоре на проведение добровольного экологического аудита, в том числе международным стандартам.

5. При проведении технологического аудита осуществляется оценка соответствия хозяйственной и (или) иной деятельности на объекте, оказывающем негативное воздействие на окружающую среду, обязательным для выполнения требованиям в области охраны окружающей среды, установленных комплексным экологическим разрешением.

6. В целях обеспечения стимулирования юридических лиц и индивидуальных предпринимателей, осуществляющих хозяйственную и (или) иную деятельность, к проведению добровольного экологического аудита копия заключения экологического аудита по результатам добровольного экологического аудита о соответствии объекта добровольного экологического аудита требованиям в области охраны окружающей среды применяется заказчиком экологического аудита в соответствии с законодательством Российской Федерации:

1) при проведении комплексного аудита - для переноса срока проведения плановой проверки объектов, оказывающих негативное воздействие, значительного, среднего или умеренного категорий риска на три года;

2) при проведении комплексного аудита - в целях снижения категории риска объекта, оказывающего негативного воздействие на окружающую среду, до следующей категории риска. Решение о снижении категории риска принимается по результатам комплексного экологического аудита и не чаще чем один раз в три года;

3) при проведении технологического аудита - для продления комплексного экологического разрешения в упрощенном порядке.

7. Законодательством субъектов Российской Федерации могут устанавливаться дополнительные не противоречащие настоящему закону механизмы стимулирования юридических лиц и индивидуальных предпринимателей, осуществляющих хозяйственную и (или) иную деятельность, к проведению добровольного экологического аудита.

\section{Статья 7. Заключение экологического аудита}

1. По результатам проведения экологического аудита составляется заключение экологического аудита. 
2. Заключение экологического аудита должно содержать:

1) наименование «Заключение экологического аудита»;

2) указание на вид экологического аудита (обязательный, добровольный комплексный, добровольный технологический) и случай его проведения (для обязательного экологического аудита);

3) дату начала и окончания проведения экологического аудита;

4) сведения об аудируемом лице: наименование, основной государственный регистрационный номер, организационно-правовую форму, адрес (место нахождения) юридического лица или фамилию, имя, отчество (при наличии), место жительства, дату государственной регистрации индивидуального предпринимателя;

5) сведения об экологической аудиторской организации, индивидуальном экологическом аудиторе, экологическом аудиторе, участвующих в проведении экологического аудита: наименование организации, фамилия, имя, отчество индивидуального экологического аудитора, экологического аудитора, государственный регистрационный номер, место нахождения, регистрационный номер лицензии на осуществление экологической аудиторской деятельности, номера квалификационных аттестатов экологических аудиторов, участвовавших в проведении экологического аудита;

6) описание объектов экологического аудита, в том числе код объекта, оказывающего негативное воздействие на окружающую среду, сведения о его фактическом месте нахождения и категории;

7) сведения о составе и объеме работ, выполненных экологической аудиторской организацией, индивидуальным экологическим аудитором для выражения мнения о соответствии объектов экологического аудита требованиям в области охраны окружающей среды;

8) описание выявленных несоответствий соблюдения юридическим лицом или индивидуальным предпринимателем требований, в том числе нормативам и нормативным документам, федеральным нормам и правилам, в области охраны окружающей среды (при наличии);

9) мнение экологической аудиторской организации, индивидуального экологического аудитора о соответствии/несоответсвии объекта экологического аудита требованиям в области охраны окружающей среды;

10) личные подписи экологических аудиторов, участвовавших в проведении экологического аудита;

11) дату утверждения заключения экологического аудита.

3. Требования к составлению и оформлению заключения экологического аудита устанавливаются уполномоченным Правительством Российской Федерации федеральным органом исполнительной власти.

4. Заключение экологического аудита утверждается руководителем экологической аудиторской организации, индивидуальным экологическим аудитором. 
5. Заключение экологического аудита представляется экологической аудиторской организацией или индивидуальным экологическим аудитором заказчику экологического аудита.

6. Дача заведомо ложного заключения экологического аудита влечет административную и уголовную ответственность.

7. Копии заключений экологического аудита, направленные в уполномоченные органы в случаях, предусмотренных частью 1 статьи 5, частью 6 статьи 6 настоящего Федерального закона, включаются в Государственный реестр заключений экологического аудита.

8. Государственный реестр заключений экологического аудита состоит из федерального государственного реестра заключений экологического аудита и региональных государственных реестров заключений экологического аудита, ведение которого осуществляется в порядке, установленном Правительством Российской Федерации.

9. Ведение федерального государственного реестра заключений экологического аудита осуществляется уполномоченным Правительством Российской Федерации федеральным органом исполнительной власти в отношении объектов, подлежащих федеральному государственному экологическому надзору.

Ведение региональных государственных реестров заключений экологического аудита в отношении объектов регионального государственного экологического надзора осуществляется органами исполнительной власти субъектов Российской Федерации.

10. Данные федерального государственного реестра заключений экологического аудита, содержащие сведения, предусмотренные в пунктах 4, 5, 9 части 2 настоящей статьи, размещаются на официальном сайте уполномоченного Правительством Российской Федерации федерального органа исполнительной власти в информационно-телекоммуникационной сети «Интернет».

Данные региональных государственных реестров заключений экологического аудита, содержащие сведения, предусмотренные в пунктах 4, 5, 9 части 2 настоящей статьи, размещаются на официальных сайтах органов исполнительной власти субъектов Российской Федерации, уполномоченных на осуществление государственного экологического надзора, в информационно-телекоммуникационной сети «Интернет».

\section{Статья 8. Права и обязанности экологических аудиторских организаций и индивидуальных экологических аудиторов}

1. При проведении экологического аудита экологические аудиторские организации и индивидуальные экологические аудиторы вправе: 
самостоятельно определять формы и методы проведения экологического аудита, руководствуясь федеральными правилами экологической аудиторской деятельности;

требовать и получать у аудируемого лица документы в области охраны окружающей среды;

получать у должностных лиц аудируемого лица разъяснения в устной и письменной формах по возникшим в ходе экологического аудита вопросам;

получать у третьих лиц сведения в устной и письменной формах по возникшим в ходе экологического аудита вопросам;

проводить необходимые для экологического аудита исследования и измерения (отбор и анализ проб воды, воздуха, почв);

отказаться от проведения экологического аудита или от выражения своего мнения о соответствии объектов экологического аудита требованиям в области охраны окружающей среды в случае:

а) непредставления аудируемым лицом всех необходимых документов в области охраны окружающей среды, документов, связанных с осуществляемой аудируемым лицом хозяйственной и (или) иной деятельностью;

б) создания препятствий изучению деятельности и обследованию территории аудируемого лица, необходимому для проведения экологического аудита;

в) выявления в ходе экологического аудита обстоятельств, оказывающих либо способных оказать существенное влияние на мнение экологической аудиторской организации, индивидуального экологического аудитора о соответствии объектов экологического аудита требованиям в области охраны окружающей среды;

осуществлять иные права, вытекающие из существа правоотношений, определенных договором на оказание услуг по проведению экологического аудита, и не противоречащие законодательству Российской Федерации.

2. При проведении экологического аудита экологические аудиторские организации, индивидуальные экологические аудиторы обязаны:

предоставлять по требованию аудируемого лица, заказчика экологического аудита необходимую информацию о требованиях законодательства Российской Федерации, касающихся проведения экологического аудита, а также о нормативных правовых актах Российской Федерации, требования которых использованы при подготовке заключения экологического аудита;

предоставлять по требованию аудируемого лица, заказчика экологического аудита информацию о ходе проведения аудита;

обеспечивать сохранность сведений, документов, получаемых и (или) составляемых ими при осуществлении экологического аудита; 
не передавать получаемые и (или) составляемые при осуществлении экологического аудита сведения, документы или их копии третьим лицам либо разглашать их содержание без письменного согласия аудируемого лица, за исключением случаев, предусмотренных законодательством Российской Федерации;

обеспечивать объективность и обоснованность выводов, сделанных ими в заключении экологического аудита;

соблюдать федеральные правила экологической аудиторской деятельности;

обеспечивать внутренний контроль качества экологической аудиторской деятельности в соответствии с утвержденными ими правилами внутреннего контроля качества экологической аудиторской деятельности, требования к организации которого устанавливаются федеральными правилами экологической аудиторской деятельности;

исполнять иные обязанности, предусмотренные договором на оказание услуг по проведению экологического аудита, и не противоречащие законодательству Российской Федерации.

3. Экологический аудит в отношении аудируемых лиц, деятельность которых составляет государственную тайну, в документах которых содержатся сведения, составляющие государственную тайну, осуществляется в соответствии с законодательством Российской Федерации о государственной тайне.

4. За неисполнение и (или) ненадлежащее исполнение своих обязанностей, составление заведомо ложного заключения экологического аудита должностные лица экологических аудиторских организаций и экологические аудиторы, в том числе индивидуальные экологические аудиторы несут дисциплинарную, гражданско-правовую, административную и уголовную ответственность, предусмотренную законодательством Российской Федерации.

5. Экологические аудиторские организации, индивидуальные экологические аудиторы вправе заниматься любой не запрещенной законодательством Российской Федерации деятельностью с учетом положений статьи 9 настоящего Федерального закона.

\section{Статья 9. Ограничения на проведение экологического аудита экологическими аудиторскими организациями, индивидуальными экологическими аудиторами}

Экологический аудит не может осуществляться:

1) экологическими аудиторскими организациями, руководители и иные должностные лица которых являются учредителями (участниками) аудируемых лиц, их должностными лицами; 
2) экологическими аудиторскими организациями, руководители и иные должностные лица которых состоят в близком родстве (родители, супруги, братья, сестры, дети, а также братья, сестры, родители, дети супругов и супруги детей) с учредителями (участниками) аудируемых лиц, их должностными лицами, несущими ответственность за организацию и осуществление производственного экологического контроля, подготовку отчетов о его результатах, подготовку документации, необходимой для получения лицензий (разрешений, экспертиз), предусмотренных законодательством в области охраны окружающей среды, проведение расчетов платы за негативное воздействие на окружающую среду;

3) экологическими аудиторскими организациями в отношении аудируемых лиц, являющихся их учредителями (участниками), в отношении аудируемых лиц, для которых эти экологические аудиторские организации являются учредителями (участниками), в отношении дочерних обществ, филиалов и представительств указанных аудируемых лиц, а также в отношении организаций, имеющих общих с этой экологической аудиторской организацией учредителей (участников);

4) экологическими аудиторскими организациями, работники которых состоят в близком родстве (родители, супруги, братья, сестры, дети, а также братья, сестры, родители, дети супругов и супруги детей) с должностными лицами, осуществляющими государственный экологический надзор;

5) экологическими аудиторскими организациями, оказывавшими аудируемым лицам в течение трех лет, непосредственно предшествовавших проведению экологического аудита, услуги по подготовке документов, которые являются объектами данного экологического аудита;

6) индивидуальными экологическими аудиторами, являющимися учредителями (участниками) аудируемых лиц, их руководителями и иными должностными лицами, несущими ответственность за организацию и осуществление производственного экологического контроля, подготовку отчетов о его результатах, подготовку документации, необходимой для получения лицензий (разрешений, экспертиз), предусмотренных законодательством в области охраны окружающей среды, проведение расчетов платы за негативное воздействие на окружающую среду;

7) индивидуальными экологическими аудиторами, состоящими в близком родстве (родители, супруги, братья, сестры, дети, а также братья, сестры, родители, дети супругов и супруги детей) с учредителями (участниками) аудируемых лиц, их должностными лицами, несущими ответственность за организацию и осуществление производственного экологического контроля, подготовку отчетов о его результатах, подготовку документации, необходимой для получения лицензий (раз- 
решений, экспертиз), предусмотренных законодательством в области охраны окружающей среды, проведение расчетов платы за негативное воздействие на окружающую среду;

8) индивидуальными экологическими аудиторами, состоящими в близком родстве (родители, супруги, братья, сестры, дети, а также братья, сестры, родители, дети супругов и супруги детей) с должностными лицами органов государственного экологического надзора.

\section{Статья 10. Права и обязанности заказчика экологического аудита}

1. При проведении экологического аудита заказчик экологического аудита вправе:

получать информацию о ходе проведения экологического аудита;

получать от экологических аудиторских организаций и индивидуального экологического аудитора информацию о требованиях законодательства Российской Федерации, на которых основывается заключение экологического аудита;

осуществлять иные права, предусмотренные договором на оказание услуг по проведению экологического аудита и не противоречащие законодательству Российской Федерации.

2. При проведении экологического аудита заказчик экологического аудита обязан:

осуществлять содействие экологическим аудиторским организациям и индивидуальным экологическим аудиторам для своевременного и полного проведения экологического аудита, предоставлять сведения, в том числе документы и документацию, необходимые для осуществления экологического аудита, давать по устному или письменному запросу экологических аудиторских организаций и индивидуального экологического аудитора исчерпывающие разъяснения и подтверждения в устной и письменной формах;

не осуществлять действий, препятствующих проведению экологического аудита;

своевременно оплачивать услуги экологической аудиторской организации и индивидуального экологического аудитора в соответствии с договором на оказание услуг по проведению экологического аудита, в том числе в случае, когда заключение экологического аудита не согласуется с позицией аудируемого лица;

исполнять иные обязанности, вытекающие из существа правоотношений, определенных договором на проведение экологического аудита, и не противоречащие законодательству Российской Федерации. 


\section{Статья 11. Лицензирование экологической аудиторской деятельности}

1. Экологическая аудиторская деятельность подлежит лицензированию в соответствии с законодательством Российской Федерации о лицензировании отдельных видов деятельности.

2. Лицензия на осуществление экологической аудиторской деятельности (далее - лицензия) выдается уполномоченным Правительством Российской Федерации федеральным органом исполнительной власти.

3. Соискателями лицензии являются юридические лица или индивидуальные предприниматели.

4. Порядок лицензирования экологической аудиторской деятельности, в том числе порядок выдачи, прекращения, переоформления и аннулирования лицензий, лицензионные требования и условия устанавливаются Правительством Российской Федерации.

\section{Статья 12. Порядок аттестации экологического аудитора}

1. Квалификационный аттестат экологического аудитора выдается уполномоченным Правительством Российской Федерации федеральным органом исполнительной власти при условии, что лицо, претендующее на его получение (далее - претендент):

1) сдало квалификационный экзамен;

2) имеет на дату подачи заявления о выдаче квалификационного аттестата экологического аудитора стаж работы в области охраны окружающей среды не менее пяти лет;

3) имеет высшее образование в области охраны окружающей среды (экологии и рационального природопользования) или высшее образование и дополнительное профессиональное образование по программе профессиональной переподготовки в области охраны окружающей среды (экологии и рационального природопользования).

2. Порядок проведения квалификационного экзамена, а также перечень вопросов, предлагаемых претенденту на квалификационном экзамене, устанавливаются уполномоченным Правительством Российской Федерации федеральным органом исполнительной власти.

3. За прием квалификационного экзамена с претендента взимается плата, размер и порядок взимания которой определяется уполномоченным Правительством Российской Федерации федеральным органом исполнительной власти.

4. Экологический аудитор обязан раз в два года начиная с года, следующего за годом получения квалификационного аттестата экологического аудитора, проходить обучение по программам повышения квалификации в области экологического аудита. 
Примерные дополнительные профессиональные программы в области экологического аудита разрабатываются и утверждаются уполномоченным Правительством Российской Федерации федеральным органом исполнительной власти в соответствии с Федеральным законом «Об образовании в Российской Федерации».

5. Правительство Российской Федерации утверждает порядок аттестации и переаттестации экологических аудиторов.

6. Решение об отказе в выдаче квалификационного аттестата экологического аудитора принимается в случае, если претендент не соответствует хотя бы одному из требований части 1 настоящей статьи.

7. Квалификационный аттестат экологического аудитора выдается на пять лет без ограничения территории его действия.

8. Экологический аудитор обязан раз в пять лет, начиная с года, следующего за годом получения квалификационного аттестата экологического аудитора, проходить переаттестацию.

К переаттестации допускается экологический аудитор при условии:

1) наличия копий удостоверений о повышении квалификации в области экологического аудита в соответствии с частью 4 настоящей статьи;

2) наличия копии квалификационного аттестата экологического аудитора.

9. Квалификационный аттестат экологического аудитора аннулируется уполномоченным Правительством Российской Федерации федеральным органом исполнительной власти в случаях:

1) получения квалификационного аттестата экологического аудитора на основании ложных сведений и подложных документов;

2) получения квалификационного аттестата экологического аудитора лицом, не соответствующим требованиям к претенденту, установленным частями 1 и 8 настоящей статьи;

3) несоблюдения экологическим аудитором требований статьи 9 настоящего Федерального закона;

4) систематического нарушения экологическим аудитором при проведении экологического аудита требований настоящего Федерального закона или федеральных правил аудиторской деятельности, подтвержденных лицензирующим органом;

5) подписания экологическим аудитором заключения, признанного в установленном порядке заведомо ложным;

6) вступления в законную силу приговора суда, предусматривающего наказание в виде лишения права заниматься экологической аудиторской деятельностью;

7) несоблюдения экологическим аудитором требования, установленного частью 4 настоящей статьи; 
8) уклонения экологического аудитора от прохождения внутреннего контроля качества работы со стороны экологической аудиторской организации, с которой экологический аудитор состоит в трудовых отношениях, подтвержденные указанной экологической аудиторской организации.

9. Уполномоченный Правительством Российской Федерации федеральный орган исполнительной власти ведет реестр выданных, а также аннулированных квалификационных аттестатов экологического аудитора в порядке, установленном Правительством Российской Федерации.

10. Решение об отказе в выдаче квалификационного аттестата экологического аудитора и об аннулировании квалификационного аттестата экологического аудитора может быть оспорено в порядке, установленном законодательством Российской Федерации.

\section{Статья 13. Порядок вступления в силу настоящего Федерального закона}

1. Настоящий Федеральный закон вступает в силу с 1 января 2021 года.

Президент

Российской Федерации 


\section{ПОЯСНИТЕЛЬНАЯ ЗАПИСКА \\ К ПРОЕКТУ ФЕДЕРАЛЬНОГО ЗАКОНА «ОБ ЭКОЛОГИЧЕСКОМ АУДИТЕ И ЭКОЛОГИЧЕСКОЙ АУДИТОРСКОЙ ДЕЯТЕЛЬНОСТИ»}

Проект федерального закона «Об экологическом аудите и экологической аудиторской деятельности» (далее - законопроект) разработан Министерством природных ресурсов и экологии Российской Федерации во исполнение пункта 112 плана законопроектной деятельности Правительства Российской Федерации на 2020 год, утвержденного распоряжением Правительства Российской Федерации от 26.12.2019 N 3205-р, а также во исполнение пункта 4 плана мероприятий по реализации Стратегии экологической безопасности Российской Федерации на период до 2025 года, утвержденной распоряжением Правительства Российской Федерации от 29.05.2019 N 1124-р.

Развитие законодательной базы в области экологического аудита предусмотрено в Классификаторе правовых актов под кодовым номером 110.010.100, введенном в действие указом Президента Российской Федерации от 15 марта 2000 г. N 511.

В соответствии с Концепцией долгосрочного социально-экономического развития Российской Федерации на период до 2020 года, утвержденной распоряжением Правительства Российской Федерации от 17 ноября 2008 года N 1662-р, развитие экологического бизнеса является одним из направлений обеспечения экологической безопасности экономического развития и улучшения экологической среды жизни человека, которое включает в себя конкурентоспособный бизнес в области экологического консалтинга.

Роль государства состоит в формировании правил осуществления экологического аудита, создании условий для широкого внедрения экологического менеджмента, повышения информационной открытости промышленных предприятий в части их воздействия на окружающую среду и предпринимаемых мер по снижению негативного воздействия, организации мониторинга динамики экологических показателей экономики.

В соответствии с Экологической доктриной Российской Федерации, одобренной распоряжением Правительства Российской Федерации от 31 августа 2002 г. N 1225-р, содействие развитию экологического аудита, предпринимательству в сфере охраны окружающей среды определено в качестве необходимого элемента развития экономических и финансовых механизмов, являющихся средствами реализации государственной политики в области экологии. 
Важным направлением реализации стратегии устойчивого развития России, направленной на сбалансированное решение социальноэкономических задач на перспективу и сохранение благоприятного качества окружающей среды, является применение экологического аудита как инструмента обеспечения благоприятного экологического климата. Данное обстоятельство связано с необходимостью интеграции России в систему мировой экономики и международной экологической безопасности, а также с усилением требований законодательства в области охраны окружающей среды.

В контексте присоединения Российской Федерации к Организации экономического сотрудничества и развития (далее - ОЭСР) планы деятельности Правительства Российской Федерации предусматривают гармонизацию российского законодательства и законодательства стран - членов ОЭСР.

В частности в отношении обращения с отходами рекомендациями ОЭСР предусмотрено введение странами - членами ОЭСР обязательного периодического экологического аудита в отношении деятельности по переработке отходов (Рекомендации ОЭСР от 9 июня 2004 г. C(2004) 100).

В настоящее время роль и место экологического аудита в системе государственного управления в области охраны окружающей среды законодательно не установлены.

Вместе с тем, в России наметился подъем промышленного производства и роста благосостояния населения страны. Однако улучшения состояния окружающей среды не происходит.

Это обусловлено, прежде всего, использованием на многих предприятиях физически и морально устаревшего оборудования, применением экологически «грязных» технологий, недостаточным вниманием к природоохранным проблемам со стороны руководства предприятий и организаций, а также отсутствием у многих из них реальных возможностей самостоятельно решать указанные проблемы.

Основными экологическими проблемами по-прежнему являются:

загрязнение атмосферного воздуха;

загрязнение водных объектов;

загрязнение почв;

возрастающее количество образования отходов производства и потребления.

Многие из перечисленных современных экологических проблем связаны с отсутствием эффективного экологического управления на конкретном хозяйствующем субъекте. Одним из элементов экологического управления является экологический аудит. 
Экологический аудит позволит проводить независимую оценку природоохранной деятельности организаций, выявлять факты и причины нарушений законодательства в области охраны окружающей среды предприятиями, предотвращать наложение штрафных санкций.

Однако достоверность результатов проведения экологического аудита, качество проведения экологического аудита зависят от наличия правовых актов, регламентирующих эту деятельность.

В настоящее время в Российской Федерации утвержден национальный стандарт ГОСТ Р ИСО 19011-2012 «Руководящие указания по аудиту систем менеджмента». Однако, международные экологические стандарты (как и национальные) являются добровольными и не заменяют законодательных требований.

В абзаце 33 статьи 1 Федерального закона от 10 января 2002 г. N 7-ФЗ «Об охране окружающей среды» дано определение экологического аудита, под которым понимается независимая, комплексная, документированная оценка соблюдения субъектом хозяйственной и иной деятельности требований, в том числе нормативов и нормативных документов, в области охраны окружающей среды, требований международных стандартов и подготовка рекомендаций по улучшению такой деятельности.

Федеральным законом от 30 декабря 2008 г. N 307-Ф3 «Об аудиторской деятельности» определены правовые основы регулирования аудиторской деятельности. Согласно статье 1 указанного Федерального закона аудитом является независимая проверка бухгалтерской (финансовой) отчетности аудируемого лица в целях выражения мнения о достоверности такой отчетности, что не относится к предмету экологического аудита.

Изложенное выше свидетельствует об отсутствии единой государственной политики в данной области, единых требований к процедуре проведения экологического аудита, единого подхода к определению содержания и сущности экологического аудита как особого вида предпринимательской деятельности по оказанию природоохранных услуг, место и роль заключения, выдаваемого по результатам экологического аудита, в системе природоохранных мероприятий не определены.

Кроме того, в настоящее время экологический аудит проводится на добровольной основе по инициативе хозяйствующих субъектов и исключительно в их интересах, и может быть связан с сокрытием имеющихся нарушений природоохранных требований от органов государственной власти и общества, а не с объективной оценкой деятельности предприятия. Ответственность за результаты проведения экологического аудита исполнитель несет только перед его заказчиком. 
Одновременно, добровольное проведение хозяйствующим субъектом экологического аудита не влияет на формы и методы государственного регулирования в отношении него и негативного воздействия, оказываемого в результате осуществления им хозяйственной и иной деятельности.

На сегодняшний день в России существуют саморегулируемые аудиторские организации, оказывающие услуги по проведению экологического аудита. В их числе:

Некоммерческое партнерство «Экологическое международное аудиторское сообщество», реестр членов которой насчитывает 33 экологические аудиторские организации и 460 экологических аудиторов;

Некоммерческое партнерство «Экологическая аудиторская палата», объединяющая 27 экологических аудиторских организаций и 367 экологических аудиторов;

Национальная экологическая аудиторская палата, включающая в себя 52 экологические аудиторские организации и 690 экологических аудиторов.

При этом, порядка 2500 экологических организаций, численность работников которых составляет около 30000 человек, потенциально являются участниками экологической аудиторской деятельности.

Количество обученных экологических аудиторов - около 3000 человек. Однако многие из них работают экологами на больших предприятиях, то есть практически не будут выполнять внешний экологический аудит.

Требования к экологическим аудиторам, их квалификации, к экологическим аудиторским организациям, индивидуальным экологическим аудиторам, ответственность за качество проведения экологического аудита и достоверность заключения экологического аудита законодательно не определены.

Данные, полученные в результате проведения экологического аудита, важны для обеспечения всестороннего обоснования управленческих решений в сфере охраны и рационального использования природных ресурсов, повышения качества окружающей среды и экологической безопасности экономического развития.

Вместе с тем, сложившиеся гражданско-правовые отношения в области экологического аудита «хозяйствующий субъект - экологический аудитор, экологическая аудиторская организация», не связанные с взаимодействием хозяйствующего субъекта с государством, не позволяют рассматривать экологический аудит как элемент перехода на экологически эффективное управление в области охраны окружающей среды. 
Законопроектом ликвидируются существующие правовые пробелы в сфере регулирования деятельности по проведению экологического аудита.

Основными целями законопроектаопределены:

предотвращение и снижение негативного воздействия хозяйственной и иной деятельности на окружающую среду и ликвидация ее последствий;

создание рынка высококачественных услуг в сфере экологического аудита;

гармонизация законодательства Российской Федерации с актами ОЭСР в части проведения обязательного экологического аудита.

Законопроект направлен на решение следующих задач:

закрепление случаев обязательного экологического аудита для субъектов хозяйственной и иной деятельности, оказывающей негативное воздействие на окружающую среду, определение периодичности проведения обязательного экологического аудита;

определение механизмов, стимулирующих хозяйствующих субъектов к проведению экологического аудита, в том числе установление особенностей государственного регулирования хозяйственной деятельности в условиях готовности бизнеса к открытому экологическому диалогу;

определение организационной структуры осуществления экологической аудиторской деятельности, определение необходимых требований, обеспечивающих высокий уровень качества проведения экологического аудита.

Законопроектом вводится новое понятие экологического аудита, которое позволяет более четко определить предмет экологического аудита и отделить экологический аудит от государственного экологического надзора. Под экологическим аудитом понимается независимая, документированная оценка соответствия объектов экологического аудита требованиям в области охраны окружающей среды.

Под объектами экологического аудита понимаются: хозяйственная и иная деятельность аудируемого лица, документы в области охраны окружающей среды, имущество, иные объекты, заявленные заказчиком добровольного экологического аудита.

Также законопроектом определяются основные понятия: экологическая аудиторская деятельность, субъекты экологического аудита, устанавливаются цели и принципы экологического аудита.

Предусмотрены два вида экологического аудита: добровольный и обязательный.

Добровольный экологический аудит проводится по инициативе субъекта хозяйственной и иной деятельности и может быть комплекс- 
ным и специальным. В целях обеспечения стимулирования субъектов хозяйственной и иной деятельности к проведению добровольного экологического аудита заключение экологического аудита по результатам добровольного экологического аудита может использоваться заказчиком экологического аудита:

1) при проведении комплексного экологического аудита - для переноса срока проведения плановой проверки регионального государственного экологического надзора на три года;

2) при проведении экологического аудита комплексного экологического разрешения - для продления комплексного экологического разрешения в упрощенном порядке.

Необходимость проведения обязательного экологического аудита хозяйственной и иной деятельности устанавливается в следующих случаях:

1) осуществления лицензируемых видов деятельности по обращению с отходами I - III классов опасности;

2) осуществления деятельности по утилизации, размещению и обезвреживанию отходов IV - V классов опасности на объектах, оказывающих негативное воздействие на окружающую среду, I и II категории.

В соответствии с Федеральным законом от 24 июня 1998 г. N 89Ф3 «Об отходах производства и потребления» утилизация отходов это использование отходов для производства товаров (продукции), выполнения работ, оказания услуг, включая повторное применение отходов, в том числе повторное применение отходов по прямому назначению (рециклинг), их возврат в производственный цикл после соответствующей подготовки (регенерация), а также извлечение полезных компонентов дляих повторного применения (рекуперация).

Поскольку утилизация отходов наиболее близко по смыслу соответствует понятию «переработка отходов» и данный вид деятельности в соответствии с Федеральным законом от 4 мая 2011 г. N 99Ф3 «О лицензировании отдельных видов деятельности» подлежит лицензированию, этот вид деятельности включен в перечень случаев необходимости проведения обязательного экологического аудита, что соответствует положениям Рекомендации ОЭСР от 9 июня 2004 г. N C(2004) 100 по экологически обоснованному обращению с отходами, которыми предусмотрено, что на объектах по переработке отходов, обладающих лицензиями/согласованиями/разрешениями должны проводиться периодические аудиты. В этом случае обязательный экологический аудит вводится с периодичностью не реже одного раза в три года;

3) реализации проекта восстановительных работ в целях возмещения вреда окружающей среде, причиненного нарушением законода- 
тельства в области охраны окружающей среды, на основании решения суда.

В соответствии со статьей 78 Федерального закона от 10 января 2002 г. N 7-Ф3 «Об охране окружающей среды» определение размера вреда окружающей среде, причиненного нарушением законодательства в области охраны окружающей среды, осуществляется исходя из фактических затрат на восстановление нарушенного состояния окружающей среды, с учетом понесенных убытков, в том числе упущенной выгоды, а также в соответствии с проектами рекультивационных и иных восстановительных работ, а при их отсутствии в соответствии с таксами и методиками исчисления размера вреда окружающей среде, утвержденными органами исполнительной власти, осуществляющими государственное управление в области охраны окружающей среды. На основании решения суда вред окружающей среде, причиненный нарушением законодательства в области охраны окружающей среды, может быть возмещен посредством возложения на ответчика обязанности по восстановлению нарушенного состояния окружающей среды за счет его средств в соответствии с проектом восстановительных работ.

При этом проверка органами государственного экологического надзора факта проведения восстановительных работ часто не объективна.

В этом случае обязательный экологический аудит вводится в целях обеспечения полноценной оценки эффективности и реальности выполнения мероприятий восстановительных работ;

3) выполнения мероприятий специальных экологических программ реабилитации радиационно загрязненных участков территории.

В соответствии с частью 2 статьи 5 Федерального закона от 10 июля 2001 г. N 92-Ф3 «О специальных экологических программах реабилитации радиационно загрязненных участков территории» специальные экологические программы работ по реабилитации радиационно загрязненных участков территории, финансируемые за счет валютных средств, поступающих от внешнеторговых операций с облученными тепловыделяющими сборками ядерных реакторов на специальный счет целевого бюджетного фонда федерального органа исполнительной власти, осуществляющего государственное управление использованием атомной энергии, подлежат государственной экологической экспертизе.

При этом ни подтверждение реализации программ, ни оценка их эффективности указанным федеральным законом не предусмотрена, что может вызывать злоупотребления в данной сфере деятельности.

В этом случае обязательный экологический аудит вводится в целях обеспечения полноценной экологической оценки эффективности 
выполнения мероприятий специальных экологических программ реабилитациирадиационно загрязненных участков территории;

4) принятия решения о признании должника банкротом и об открытии конкурсного производства в отношении должника, признанного банкротом и осуществлявшего деятельность на объектах, оказывающих негативное воздействие на окружающую среду, I и II категории проведение экологического аудита позволит оценить имущество и документы в области охраны окружающей среды должника, имущественные комплексы, используемые для промышленного производства, подлежащие приватизации, требованиям в области охраны окружающей среды в части наличия задолженностей по плате за негативное воздействие на окружающую среду, обязательств по восстановлению нарушенного состояния окружающей среды в результате деятельности указанного объекта.

Иных случаев необходимости проведения обязательного экологического аудита законопроект не устанавливает.

Периодичность проведения обязательного экологического аудита также устанавливается в законопроекте.

В качестве механизма обеспечения государственного регулирования экологической аудиторской деятельности законопроектом предусмотрено лицензирование экологической аудиторской деятельности уполномоченным Правительством Российской Федерации федеральным органом исполнительной власти Российской Федерации - Росприроднадзором.

Принятие законопроекта будет способствовать обеспечению:

полноценной оценки эффективности и реальности выполнения планов снижения объемов негативного воздействия, декларируемых хозяйствующими субъектами;

полноценной оценки эффективности реализации восстановительных работ по возмещению вреда, причиненного окружающей среде, и по реабилитации радиационно загрязненных участков территории;

созданию эффективного сектора экономики в области природоохранных услуг.

Законопроект в полной мере соответствует приоритетным направлениям деятельности Правительства Российской Федерации и является одним из компонентов совершенствования государственного управления в области охраны окружающей среды. 


\section{ФИНАНСОВО-ЭКОНОМИЧЕСКОЕ ОБОСНОВАНИЕ К ПРОЕКТУ ФЕДЕРАЛЬНОГО ЗАКОНА «ОБ ЭКОЛОГИЧЕСКОМ АУДИТЕ И ЭКОЛОГИЧЕСКОЙ АУДИТОРСКОЙ ДЕЯТЕЛЬНОСТИ»}

Принятие и реализация проекта федерального закона «Об экологическом аудите и экологической аудиторской деятельности» потребует увеличения штатной численности центрального аппарата Росприроднадзора не менее, чем на 15 штатных единиц (предполагая, что осуществление лицензирования экологической аудиторской деятельности, а также организация ведения федерального государственного реестра заключений экологического аудита и реестра выданных и аннулированных квалификационных аттестатов будет осуществляться центральным аппаратом Росприроднадзора), а также на 160 штатных единиц в территориальных органах (учитывая необходимость проведения квалификационных экзаменов, аттестации и переаттестации экологических аудиторов, а также проведения проверочных мероприятий в рамках лицензирования при установлении соответствующего порядка лицензирования).

Фонд оплаты труда и предельная численность федеральных государственных гражданских служащих центрального аппарата и территориальных органов Росприроднадзора установлены постановлением Правительства Российской Федерации от 30.12.2017 N 1724 «О предельной численности и фонде оплаты труда федеральных государственных гражданских служащих и работников, замещающих должности, не являющиеся должностями федеральной государственной гражданской службы, центральных аппаратов и территориальных органов федеральных органов исполнительной власти, а также о признанииутратившими силу некоторых актов Правительства Российской Федерации» (далее - постановление N 1724).

В соответствии с постановлением N 1724 оплата труда 1 работника территориального органа Росприроднадзора (без учета персонала по охране и обслуживанию зданий) составляет 343,9 тыс. рублей в расчете на год, центрального аппарата - 491,9 тыс. рублей в расчете на год.

Дополнительные расходы на содержание дополнительных штатных единиц (центральный аппарат и территориальные органы) составят 113 054,5 тыс. рублей ежегодно, из них:

оплата труда федеральных государственных гражданских служащих центрального аппарата - 7 378,5 тыс. рублей (491,9 x 15), без учета индексации; 
начисления на оплату труда (центральный аппарат) - 2 229,0 тыс. рублей (7 378,5 * 30,2\%), без учета индексации;

оплата труда федеральных государственных гражданских служащих территориальных органов - 55 024,0 тыс. рублей (343,9 x 160) без учета индексации;

начисления на оплату труда (территориальные органы) - 16 608,0 тыс. рублей (55 024,0 × 30,2\%), без учета индексации;

командировочные расходы - 3 727,5 тыс. рублей;

расходы на содержание - 23 362,5 тыс. рублей;

расходы на аренду площадей (исходя из установленной постановлением Правительства Российской Федерации от 05.01.1998 N 3 нормы 9 кв. м на 1 сотрудника и средней стоимости аренды 1 кв. м площади в размере 3 тыс. рублей в год) 4 725,0 тыс. рублей $(3,0 \times 9$ × 175). При определении дополнительного финансирования из средств федерального бюджета полагаем необходимым, помимо расходов на оплату труда и содержания дополнительной численности, предусмотреть расходы на ведение федерального государственного реестра заключений экологического аудита и реестра выданных и аннулированных квалификационных аттестатов (на создание и поддержание функционирования соответствующего информационного ресурса). 


\section{ПЕРЕЧЕНЬ \\ ФЕДЕРАЛЬНЫХ ЗАКОНОВ, ПОДЛЕЖАЩИХ ПРИЗНАНИЮ УТРАТИВШИМИ СИЛУ, ПРИОСТАНОВЛЕНИЮ, ИЗМЕНЕНИЮ ИЛИ ПРИНЯТИЮ В СВЯЗИ С ПРИНЯТИЕМ ФЕДЕРАЛЬНОГО ЗАКОНА «ОБ ЭКОЛОГИЧЕСКОМ АУДИТЕ И ЭКОЛОГИЧЕСКОЙ АУДИТОРСКОЙ ДЕЯТЕЛЬНОСТИ»}

Принятие предлагаемого проекта федерального закона «Об экологическом аудите и экологической аудиторской деятельности» (далее законопроект) потребует внесения изменений в следующие федеральные законы: Федеральный закон от 24 июня 1998 года N 89-Ф3 «Об отходах производства и потребления», Федеральный закон от 10 июля 2001 года N 92-Ф3 «О специальных экологических программах реабилитации радиационно загрязненных участков территории", Федеральный закон от 10 января 2002 года N 7-Ф3 «Об охране окружающей среды», Федеральный закон от 26 октября 2002 года N 127-Ф3 «О несостоятельности (банкротстве)», Федеральный закон от 21 декабря 2001 года N 178-Ф3 «О приватизации государственного и муниципального имущества».

Необходимо будет дополнить нормы указанных федеральных законов в связи с введением законопроектом случаев обязательного экологического аудита.

Федеральные органы исполнительной власти, ответственные за подготовку: головной - Минприроды России, соисполнители - Минэкономразвития России, Росприроднадзор, заинтересованные федеральные органы исполнительной власти.

Кроме того, потребуется внесение изменений в Федеральный закон от 4 мая 2011 года N 99-Ф3 «О лицензировании отдельных видов деятельности».

Необходимо будет дополнить нормы указанного федерального закона в части включения в перечень видов деятельности, на которые требуются лицензии, экологическую аудиторскую деятельность.

Федеральные органы исполнительной власти, ответственные за подготовку: головной - Минприроды России, соисполнители - Минфин России, Росприроднадзор, заинтересованные федеральные органы исполнительной власти.

В связи с введением мер стимулирования юридических лиц и индивидуальных предпринимателей, осуществляющих хозяйственную и иную деятельность, к проведению добровольного экологического аудита, потребуется внесение изменений в Федеральный закон от 26 декабря 2008 года N 294-Ф3 «О защите прав юридических лиц и индивидуальных пред- 
принимателей при осуществлении государственного контроля (надзора) и муниципального контроля», Федеральный закон от 21 июля 2014 года N 219-Ф3 «Овнесении изменений в Федеральный закон «Об охране окружающей среды» и отдельные законодательные акты Российской Федерации".

Необходимо будет дополнить нормы указанных федеральных законов в части переноса срока проведения плановой проверки регионального государственного экологического надзора на три года в случае проведения комплексного экологического аудита и в части продления комплексного экологического разрешения в упрощенном порядке в случае проведения экологического аудита комплексного экологического разрешения.

Федеральные органы исполнительной власти, ответственные за подготовку: головной - Минприроды России, соисполнители - Росприроднадзор, заинтересованные федеральные органы исполнительной власти.

Также, потребует внесение изменений Федеральный закон от 29 декабря 2012 года N 273-Ф3 «Об образовании в Российской Федерации».

Необходимо будет дополнить нормы указанного федерального закона в части установления особенностей реализации образовательных программ в области экологического аудита.

Федеральные органы исполнительной власти, ответственные за подготовку: головной - Минприроды России, соисполнители - Минобрнауки России, Росприроднадзор, заинтересованные федеральные органы исполнительной власти.

Кроме того, потребует внесения изменений в Кодекс Российской Федерации об административных правонарушениях.

Необходимо будет дополнить нормы указанного Кодекса в части введения установления административной ответственности за невыполнение требований законодательства об обязательном проведении экологического аудита, за дачу заведомо ложного заключения экологического аудита.

Федеральные органы исполнительной власти, ответственные за подготовку: головной - Минприроды России, соисполнители - Росприроднадзор, заинтересованные федеральные органы исполнительной власти.

Потребует внесение изменений Уголовный кодекс Российской Федерации.

Необходимо будет дополнить нормы указанного Кодекса в части введения уголовной ответственности экологического аудитора за дачу заведомо ложного заключения экологического аудита. 
Федеральные органы исполнительной власти, ответственные за подготовку: головной - Минприроды России, соисполнители - Росприроднадзор, заинтересованные федеральные органы исполнительной власти.

Внесение изменений в указанные проекты федеральных законов предполагается единым нормативным актом, сроки подготовки которого определены пунктом 26 Плана законопроектной деятельности Правительства Российской Федерации на 2015 год, утвержденного распоряжением Правительства Российской Федерации от 27.12.2014 N 2736-p. 


\section{ПЕРЕЧЕНЬ \\ НОРМАТИВНЫХ ПРАВОВЫХ АКТОВ ПРЕЗИДЕНТА \\ РОССИЙСКОЙ ФЕДЕРАЦИИ,ПРАВИТЕЛЬСТВА \\ РОССИЙСКОЙ ФЕДЕРАЦИИ И ФЕДЕРАЛЬНЫХ ОРГАНОВ ИСПОЛНИТЕЛЬНОЙ ВЛАСТИ, ПОДЛЕЖАЩИХ ПРИЗНАНИЮ УТРАТИВШИМИ СИЛУ, ИЗМЕНЕНИЮ ИЛИ ПРИНЯТИЮ \\ В СВЯЗИ С ПРИНЯТИЕМ ФЕДЕРАЛЬНОГО ЗАКОНА «ОБ ЭКОЛОГИЧЕСКОМ АУДИТЕ И ЭКОЛОГИЧЕСКОЙ АУДИТОРСКОЙ ДЕЯТЕЛЬНОСТИ»}

Принятие проекта федерального закона «Об экологическом аудите и экологической аудиторской деятельности» (далее - законопроект) потребует принятия следующих постановлений Правительства Российской Федерации:

1. «О внесении изменений в некоторые акты Правительства Российской Федерации в связи с принятием федерального закона «Об экологическом аудите и экологической аудиторской деятельности».

Принятие акта Правительства Российской Федерации необходимо в целях приведения некоторых актов Правительства Российской Федерации в соответствие с законопроектом. В частности, потребуется внесение изменений в постановление Правительства Российской Федерации от 30 июля 2004 г. N 400 «Об утверждении Положения о Федеральной службе по надзору в сфере природопользования и внесении изменений в Постановление Правительства Российской Федерации от 22 июля 2004 г. N 370", постановление Правительства Российской Федерации от 27 января 2009 г. N 53 «Об осуществлении государственного контроля в области охраны окружающей среды (государственного экологического контроля)».

Федеральные органы исполнительной власти, ответственные за подготовку: головной - Минприроды России, соисполнители - Минэкономразвития России, Минфин России, Росприроднадзор.

Примерный срок подготовки проекта: в течение 3 месяцев с момента принятия законопроекта.

2. «О полномочиях федеральных органов исполнительной власти, связанных с регулированием организации и осуществления экологической аудиторской деятельности».

Обоснованием необходимости подготовки проекта акта Правительства Российской Федерации являются положения законопроекта, предусматривающие, что уполномоченный Правительством Российской Федерации федеральный орган исполнительной власти осуществляет 
полномочия по утверждению порядка проведения квалификационного экзамена (часть 2 статьи 12 законопроекта), согласованию перечня вопросов, предлагаемых претенденту на квалификационном экзамене (часть 2 статьи 12законопроекта), установлению размера и порядка взимания платы с претендента за квалификационный экзамен (часть 3 статьи 12 законопроекта), установлению порядка по ведению реестра выданных, а также аннулированных квалификационных аттестатов экологического аудитора (часть 10 статьи 12 законопроекта), утверждению требований к минимальному содержанию программ повышения квалификации экологических аудиторов (часть 4 статьи 12 законопроекта).

Федеральные органы исполнительной власти, ответственные за подготовку проекта акта: головной - Минприроды России, соисполнители - Минэкономразвития России, Минфин России, Минобрнауки России, Росприроднадзор.

Срок подготовки проекта акта: до рассмотрения законопроекта в третьем чтении Государственной Думой Федерального Собрания Российской Федерации.

3. «Федеральные правила экологической аудиторской деятельносТИ».

Обоснованием необходимости подготовки проекта акта Правительства Российской Федерации является положение части 2 статьи 3 законопроекта о том, что федеральные правила экологической аудиторской деятельности утверждаются Правительством Российской Федерации.

Федеральные органы исполнительной власти, ответственные за подготовку проекта акта: головной - Минприроды России, соисполнители - Минэкономразвития России, Росприроднадзор, Российская академия наук.

Примерный срок подготовки проекта акта: до рассмотрения законопроекта в третьем чтении Государственной Думой Федерального Собрания Российской Федерации.

4. «О порядке ведения государственного реестра заключений экологического аудита».

Обоснованием необходимости подготовки проекта акта Правительства Российской Федерации является положение части 8 статьи 7 законопроекта, предусматривающей, что ведение государственного реестра заключений экологического аудита осуществляется в порядке, установленном Правительством Российской Федерации.

Федеральные органы исполнительной власти, ответственные за подготовку проекта акта: головной - Минприроды России, соисполнители - Минэкономразвития России, Росприроднадзор. 
Примерный срок подготовки проекта акта: до рассмотрения законопроекта в третьем чтении Государственной Думой Федерального Собрания Российской Федерации.

5. «О порядке лицензирования экологической аудиторской деятельности».

Обоснованием необходимости подготовки проекта акта Правительства Российской Федерации является положение части 4 статьи 11 законопроекта о том, что порядок лицензирования экологической аудиторской деятельности, в том числе порядок выдачи, прекращения, переоформления и аннулирования лицензий, лицензионные требования и условия устанавливаются Правительством Российской Федерации.

Федеральные органы исполнительной власти, ответственные за подготовку проекта акта: головной - Минприроды России, соисполнители - Минэкономразвития России, Росприроднадзор.

Примерный срок подготовки проекта акта: до рассмотрения законопроекта в третьем чтении Государственной Думой Федерального Собрания Российской Федерации.

6. «О порядке аттестации и переаттестации экологических аудитоpoB».

Обоснованием необходимости подготовки проекта акта Правительства Российской Федерации является положение части 5 статьи 12 законопроекта о том, что Правительство Российской Федерации утверждает порядок аттестации и переаттестации экологических аудиторов.

Федеральные органы исполнительной власти, ответственные за подготовку проекта акта: головной - Минприроды России, соисполнители - Минэкономразвития России, Росприроднадзор.

Примерный срок подготовки проекта акта: до рассмотрения законопроекта в третьем чтении Государственной Думой Федерального Собрания Российской Федерации.

7. «О порядке ведения реестра выданных, а также аннулированных квалификационных аттестатов экологического аудитора».

Обоснованием необходимости подготовки проекта акта является положение части 9 статьи 12 законопроекта о том, что уполномоченный Правительством Российской Федерации федеральный орган исполнительной власти ведет реестр выданных, а также аннулированных квалификационных аттестатов экологического аудитора в порядке, установленном Правительством Российской Федерации.

Федеральные органы исполнительной власти, ответственные за подготовку проекта акта: головной - Минприроды России, соисполнители - Минэкономразвития России, Росприроднадзор. 
Примерный срок подготовки проекта акта: до рассмотрения законопроекта в третьем чтении Государственной Думой Федерального Собрания Российской Федерации.

Кроме того, потребуется издание приказов уполномоченного Правительством Российской Федерации федерального органа исполнительной власти:

1. «Об утверждении Порядка ведения федерального государственного реестра заключений экологического аудита в отношении объектов, подлежащих федеральному государственному экологическому над3ору».

Обоснованием необходимости подготовки проекта акта является положение части 9 статьи 7 законопроекта о том, что ведение федерального государственного реестра заключений экологического аудита осуществляется уполномоченным Правительством Российской Федерации федеральным органом исполнительной власти в отношении объектов, подлежащих федеральному государственному экологическому надзору.

Федеральные органы исполнительной власти, ответственные за подготовку проекта акта: головной - Минприроды России, соисполнители - Минэкономразвития России, Росприроднадзор.

Примерный срок подготовки проекта акта: до рассмотрения законопроекта в третьем чтении Государственной Думой Федерального Собрания Российской Федерации.

2. «Об утверждении Порядка проведения квалификационного экзамена на получение квалификационного аттестата экологического аудитора».

Обоснованием необходимости подготовки проекта акта является положение части 2 статьи 12 законопроекта о том, что проверка квалификации претендента осуществляется в форме квалификационного экзамена, порядок проведения которого, устанавливается уполномоченным Правительством Российской Федерации федеральным органом исполнительной власти.

Федеральные органы исполнительной власти, ответственные за подготовку проекта акта: головной - Минприроды России, соисполнители - Минэкономразвития России, Минфин России, Росприроднадзор.

Примерный срок подготовки проекта акта: до рассмотрения законопроекта в третьем чтении Государственной Думой Федерального Собрания Российской Федерации.

3. «Об утверждении размера и Порядка взимания платы за прием квалификационного экзамена с лица, претендующего на получение квалификационного аттестата экологического аудитора». 
Обоснованием необходимости подготовки проекта акта является положение части 3 статьи 12 законопроекта о том, что за прием квалификационного экзамена с претендента взимается плата, размер и порядок взимания которой определяется уполномоченным Правительством Российской Федерации федеральным органом исполнительной власти.

Федеральные органы исполнительной власти, ответственные за подготовку проекта акта: головной - Минприроды России, соисполнители - Минэкономразвития России, Минфин России, Росприроднадзор.

Примерный срок подготовки проекта акта: до рассмотрения законопроекта в третьем чтении Государственной Думой Федерального Собрания Российской Федерации.

4. «Об утверждении требований к минимальному содержанию примерных дополнительных профессиональных программ в области экологического аудита».

Обоснованием необходимости подготовки проекта акта является положение части 4 статьи 12 законопроекта о том, что примерные дополнительные профессиональные программы в области экологического аудита разрабатываются и утверждаются уполномоченным Правительством Российской Федерации федеральным органом исполнительной власти в соответствии с Федеральным законом «Об образовании в Российской Федерации».

Федеральные органы исполнительной власти, ответственные за подготовку проекта акта: головной - Минприроды России, соисполнители - Минобрнауки России, Росприроднадзор.

Примерный срок подготовки проекта акта: до рассмотрения законопроекта в третьем чтении Государственной Думой Федерального Собрания Российской Федерации. 
ФОРМА

\title{
сводного отчета о проведении оценки регулирующего воздействия проекта акта с высокой степенью регулирующего воздействия
}

\author{
ЗАКЛЮЧЕНИЕ \\ от 5 ноября 2020 г. N 36766-АХ/Д26и
}

\section{ОБ ОЦЕНКЕ РЕГУЛИРУЮЩЕГО ВОЗДЕЙСТВИЯ НА ПРОЕКТ ФЕДЕРАЛЬНОГО ЗАКОНА «ОБ ЭКОЛОГИЧЕСКОМ АУДИТЕ И ЭКОЛОГИЧЕСКОЙ АУДИТОРСКОЙ ДЕЯТЕЛЬНОСТИ»}

Минэкономразвития России в соответствии с разделом IV Правил проведения федеральными органами исполнительной власти оценки регулирующего воздействия проектов нормативных правовых актов и проектов решений Евразийской экономической комиссии, утвержденных постановлением Правительства Российской Федерации от 17 декабря 2012 г. N 1318 (далее - Правила), рассмотрело проект федерального закона «Об экологическом аудите и экологической аудиторской деятельности» (далее - проект акта), разработанный и направленный для подготовки настоящего заключения Минприроды России (далее разработчик), и сообщает следующее.

Согласно сводному отчету и пояснительной записке проект акта подготовлен во исполнение пункта 112 плана законопроектной деятельности Правительства Российской Федерации на 2020 год, утвержденного распоряжением Правительства Российской Федерации от 26 декабря 2019 г. N 3205-р, а также во исполнение пункта 4 плана мероприятий по реализации Стратегии экологической безопасности Российской Федерации на период до 2025 года, утвержденной распоряжением Правительства Российской Федерации от 29 мая 2019 г. N 1124-p.

Согласно позиции разработчика ввиду того, что в настоящее время законодательно не установлены роль и место экологического аудита в системе государственного управления в области охраны окружающей среды, необходимо нормативно урегулировать данную деятельность.

В качестве основных целей предлагаемого введения экологического аудита разработчиком предлагается считать предотвращение и снижение негативного воздействия хозяйственной и иной деятельности на окружающую среду и ликвидацию его последствий, создание рынка высококачественных услуг в сфере экологического аудита, гармонизацию законодательства Российской Федерации с актами Организации 
экономического сотрудничества и развития (далее - ОЭСР) в части проведения обязательного экологического аудита.

Разработчиком проведены публичные обсуждения проекта акта и сводного отчета о проведении оценки регулирующего воздействия (далее - сводный отчет) в срок с 22 июля по 18 августа 2020 года. Информация об оценке регулирующего воздействия проекта акта размещена разработчиком на официальном сайте в информационно-телекоммуникационной сети «Интернет» по адресу: regulation.gov.ru (ID проекта акта: 02/04/07-20/00106155). Замечания и предложения, поступившие в ходе публичных обсуждений, прокомментированы разработчиком в сводке предложений.

По результатам рассмотрения представленных разработчиком проекта акта и сводного отчета установлено, что при подготовке проекта акта процедуры, предусмотренные пунктами 9 - 23 Правил, разработчиком соблюдены.

В целях подготовки настоящего заключения в соответствии с пунктом 28 Правил Минэкономразвития России проведены дополнительные публичные консультации по проекту акта в период с 13 по 21 октября 2020 года.

В рамках проведенных публичных консультаций поступили позиции от Российского союза промышленников и предпринимателей, ПАО «Газпром нефть», $\mathrm{AO}$ «HXC», $\mathrm{AO}$ «Мосинжпроект», $\mathrm{AO}$ «Омскоблгаз», Госкорпорации «Росатом», АО «Холдинговая Компания «Сибирский цемент», АО «Сибирская угольная энергетическая компания», ПАО «ЛУКОЙЛ», ООО «Байкальская энергетическая компания», ПАО АНК «Башнефть», ООО «Иркутская нефтяная компания», Ассоциации «Совет производителей энергии», АО «Атомэнергопроект», ПАО «Газпром нефть», ПАО «Россети», АО «КонцернРосэнергоатом», Ассоциации РАТЭК, ПАО «Группа Компаний ПИК», ПАО «НОВАТЭК», ПАО «Татнефть» им. В.Д. Шашина, ЕМУП «Спецавтобаза», Союза «Тамбовская областная торгово-промышленная палата", Департамента экономического развития Белгородской области, Управления экономического развития Липецкой области, Департамента экономики Ямало-Ненецкого автономного округа, Департамента природных ресурсов и экологии Чукотского автономного округа, Министерства экономического развития Приморского края, Министерства экономики Республики Татарстан, Министерства экономического развития и поддержки предпринимательства Кировской области, Министерства природных ресурсов, экологии и охраны окружающей среды Республики Марий Эл, Правительства Хабаровского края, замечания которых были частично учтены, а также прилагаются к настоящему заключению в целях рассмотрения и возможного учета при доработке проекта акта. 
Проект акта не поступал на рассмотрение профильной рабочей группе по реализации механизма «регуляторной гильотины» в сфере экологии и природопользования.

В связи с этим, а также учитывая, что предлагаемое регулирование является новым, считаем необходимым направление проекта акта на рассмотрение рабочей группе и его доработку по замечаниям рабочей группы в случае их поступления.

Отдельно следует отметить, что проект акта направлен на заключение об оценке регулирующего воздействия повторно. Ранее Минэкономразвития России в рамках оценки регулирующего воздействия трижды рассматривало проект акта в разных редакциях. При этом на все ранее представленные редакции были подготовлены отрицательные заключения об оценке регулирующего воздействия (далее - Заключения) <1>, в которых в том числе были изложены замечания концептуального характера, связанные с необходимостью уточнения вопроса целесообразности введения предлагаемого регулирования.

С учетом информации, представленной разработчиком по проекту акта, Минэкономразвития России в рамках оценки регулирующего воздействия обращает внимание на следующее.

1. Замечания, ранее представленные в Заключениях, сохраняют свою актуальность, в том числе и в первую очередь в отношении отсутствия достаточной фактологической обоснованности разработки проекта акта, а также в части нецелесообразности вменения дополнительных расходов хозяйствующим субъектам в отсутствие таких обоснований и анализа эффектов от введения в действие предлагаемого регулирования, а также оценки расходов хозяйствующих субъектов.

В этой связи обращаем внимание разработчика на положения статьи 6 Федерального закона от 31 июля 2020 г. N 247-Ф3 «Об обязательных требованиях в Российской Федерации» (далее - Закон об обязательных требованиях), который в этой части вступил в силу 1 ноября 2020 года.

Указанной статьей в том числе установлен принцип обоснованности обязательных требований. В частности, данной статьей предусмотрено, что оценка наличия риска причинения вреда (ущерба) охраняемым законом ценностям, проводимая федеральным органом исполнительной власти или уполномоченной организацией при разработке проекта нормативного правового акта, устанавливающего обязатель-

$<1>$ Заключения об оценке регулирующего воздействия от 5 декабря 2013 г. N 26971-ОФ/Д26и, от 30 декабря 2014 г. N 33145-ОФ/Д26и, от 23 июня 2015 г. N 16449-АВ/Д26и. 
ные требования, должна основываться на анализе объективной и регулярно собираемой информации об уровне причиненного охраняемым законом ценностям вреда (ущерба) и (или) иной информации применительно к отношениям, при регулировании которых предполагается установление обязательных требований. Необходимыми условиями установления обязательных требований являются наличие риска причинения вреда (ущерба) охраняемым законом ценностям, на устранение которого направлено установление обязательных требований, и возможность и достаточность установления обязательных требований в качестве мер защиты охраняемых законом ценностей.

Также статьей 9 Закона об обязательных требованиях установлен принцип исполнимости обязательных требований. В частности, при установлении обязательных требований оцениваются затраты лиц, в отношении которых они устанавливаются, на их исполнение.

Кроме того, ключевым замечанием к проекту акту являлась и является недопустимость подмены и дублирования отдельных функций государственного экологического надзора $<2>$, являющегося полномочием и обязанностью уполномоченного государственного органа и осуществляемого за счет бюджетных средств, обязательным экологическим аудитом, который предлагается осуществлять коммерческим организациям за счет средств хозяйствующих субъектов.

Подтверждая ранее представленную позицию, в отношении рассматриваемой редакции проекта акта отдельно отмечаем следующее.

1.1. В представленной редакции сводный отчет (пункт 11) и иные пояснительные материалы также не содержат оценки расходов субъектов предпринимательской и иной экономической деятельности, связанных с необходимостью проведения обязательного экологического аудита. При этом в пункте 10 сводного отчета указано, что новые обязанности для хозяйствующих субъектов проектом акта не вводятся, что не соответствует содержанию проекта акта.

При этом в части предполагаемых расходов на проведение экологического аудита в отношении случаев, указанных в подпунктах 1 и 2 пункта 1 статьи 5 проекта акта - случаев осуществления лицензируемых видов деятельности по обращению с отходами I - III классов опасности и осуществления деятельности по утилизации, размещению и обезвреживанию отходов IV - V классов опасности на объектах, оказывающих негативное воздействие на окружающую среду (далее - НBOC), I и |l категории, отмечаем следующее.

Если исходить из того, что в настоящее время количество действующих лицензий на осуществление лицензируемых видов деятельнос-

<2> Постановление Правительства Российской Федерации от 8 мая 2014г. N 426 «О федеральном государственном экологическом надзоре». 
ти по обращению с отходами составляет около 18 тыс. <3>, а минимальная стоимость экологического аудита, рассчитанная по данным открытых источников <4>, в среднем составляет 89 тыс. рублей, тогда расходы таких организаций в целом составят более 1,6 млрд рублей, причем каждые 3 года (согласно пункту 2 статьи 5 проекта акта).

Однако, учитывая, что проектом акта предлагается вводить лицензирование экологической аудиторской деятельности, а также сложную систему аттестации экологических аудиторов, очевидно, что вышеуказанные расходы увеличатся.

Отдельно следует отметить, что актуальная редакция проекта акта лишь незначительно отличается от ранее направляемых редакций, на которые были подготовлены отрицательные Заключения, в частности, от последней предшествующей редакции 2015 года. Одним из таких отличий можно назвать расширение случаев, в которых должен проводиться обязательный экологический аудит. При этом оценка количества участников отношений (7 500) в актуальной версии сводного отчета не отличается от данных сводного отчета пятилетней давности, что представляется некорректным.

Кроме того, как было отмечено выше в настоящем заключении, указанная оценка не совпадает с количеством действующих лицензий на осуществление лицензируемых видов деятельности по обращению с отходами.

Также сводный отчет не содержит информации о новых функциях, полномочиях, обязанностях федеральных органов исполнительной власти, органов государственной власти субъектов Российской Федерации, а также оценки соответствующих расходов бюджетов бюджетной системы Российской Федерации.

При этом в финансово-экономическом обосновании приведены предполагаемые расходы в связи с необходимостью увеличения штатной численности центрального аппарата Росприроднадзора и его территориальных органов, составляющие, по оценке разработчика, 113 млн рублей ежегодно.

Однако не представлено данных о необходимости увеличения штатной численности органов исполнительной власти субъектов Российс-

<3> По данным Росприроднадзора по состоянию на 20 июля 2020 г., представленным в Минэкономразвития России письмом от 20 июля 2020 г. N AA-10-01-29/23088.

$<4>$ https://sud-expertiza.ru/ekologicheskiy-audit/

https://mosekologiya.ru/ekologicheskiy-audit-predpriyatiya.php

https://r-holding.ru/services/ekologicheskij_audit/

https://moskva.econsalt.ru/ekologicheskij-audit

https://ecosafelab.ru/uslugi/ekologicheskij-audit.html. 
кой Федерации, которые в соответствии с проектируемыми положениями обязаны будут обеспечивать прием копий заключений экологического аудита, а также ведение региональных государственных реестров заключений экологического аудита в отношении объектов регионального государственного экологического надзора.

Принимая во внимание значительное количество объектов, подлежащих региональному экологическому надзору, по информации участников публичных консультаций, для этих целей потребуется выделение не менее 3 штатных единиц, что в денежном эквиваленте для 85 субъектов Российской Федерации составит более 200 млн рублей бюджетных средств ежегодно. Одновременно потребуется финансирование внедрения и обеспечения функционирования региональных государственных реестров заключений экологического аудита, необходимый объем которого разработчиком также не проанализирован и/или не представлен.

Таким образом, прогнозируемый объем только бюджетного финансирования может составлять свыше 313 млн рублей ежегодно.

Кроме того, разработчиком, как указано выше, не представлены оценки затрат субъектов предпринимательской деятельности на реализацию обсуждаемого регулирования и стоимостные оценки его возможных положительных эффектов. Таким образом, в отсутствие оценки выгод/издержек предлагаемого регулирования не представляется возможным сделать вывод о его обоснованности.

1.2. Проект акта, как было указано выше, представляет собой новое регулирование, в связи с чем имеет высокую степень регулирующего воздействия.

Обращаем внимание разработчика на пункт 8(1) Правил, согласно которому в случае если проекты актов, регулирующих отношения, указанные в пункте 60(1) Регламента Правительства Российской Федерации, утвержденного постановлением Правительства Российской Федерации от 1 июня 2004 г. N 260, имеют высокую степень регулирующего воздействия, такие проекты актов должны предусматривать положения об отмене соразмерных требований в той же области правового регулирования.

В этой связи, учитывая ранее изложенную позицию Минэкономразвития России, что предлагаемый экологический аудит ничем по сути не отличается от государственного экологического надзора и лицензионного контроля, то есть относится к той же области правового регулирования, требуются либо иные обоснования для разработки такого регулирования и изменение его конструкции и концепции, либо исключение объектов экологического аудита из объектов государственного экологического надзора и лицензионного контроля. 
1.3. Разработчиком в пояснительной записке в общем виде упоминается сложившаяся практика проведения экологического аудита на добровольной основе по инициативе хозяйствующих субъектов.

Вместе с тем отсутствует информация об эффективности либо неэффективности добровольного экологического аудита. Разработчиком подобный анализ правоприменительной практики в рассматриваемой сфере проведен не был.

В связи с этим утверждение, что внедряемый экологический аудит позволит, например, снизить НВОС, не подкреплено конкретными данными об успешных итогах ранее проведенных экологических аудитов, благодаря которым аудируемое лицо могло самостоятельно предпринять меры по снижению HBOC, что было бы подтверждено, например, в рамках осуществления государственного экологического надзора.

Учитывая изложенное, не представляется возможным соотнести цели предлагаемого регулирования с его заявленными ожидаемыми эффектами.

1.4. Разработчик с момента первоначальной разработки проекта акта в качестве одного из оснований для введения экологического аудита приводит необходимость гармонизации российского законодательства и законодательства стран-членов ОЭСР, ссылаясь на Рекомендацию ОЭСР от 9 июня 2004 г. С(200) 100.

Обращаем внимание, что, во-первых, разработчиком не заполнен раздел сводного отчета, посвященный анализу международного опыта в рассматриваемой сфере.

Во-вторых, как таковой анализ международного опыта разработчиком проведен не был, имея в виду, что не была изучена практика внедрения экологического аудита, причем обязательного, в странах-участницах ОЭСР.

В связи с этим данное обоснование для разработки проекта акта представляется не вполне состоятельным.

2. Поскольку при разработке проекта акта не учитывалась правоприменительная практика проведения добровольного экологического аудита, полагаем необходимым первоначально обеспечить содействие развитию данной сферы в условиях добровольного применения без установления обязательного экологического аудита и введения государственного регулирования одномоментно на всей территории Российской Федерации.

С этой целью, а также ввиду изложенной в пункте 1 настоящего заключения позиции об отсутствии данных правоприменительной практики в данной сфере для принятия однозначного решения о его необходимости, полагаем целесообразным рекомендовать разработчику в соответствии со статьей 13 Закона об обязательных требованиях про- 
работать вопрос установления экспериментального правового режима на определенной территории.

Установление такого экспериментального правового режима позволит проанализировать эффективность предлагаемой процедуры, в том числе посредством проведения сравнительного анализа нарушений, выявленных по итогам проведения экологического аудита и в рамках государственного экологического надзора или лицензионного контроля.

Разработчиком в пояснительной записке указано, что проверки, проводимые органами государственного экологического надзора, характеризуются как зачастую необъективные. При этом данное утверждение не конкретизировано и не подкреплено практическими примерами. Таким образом, в представленных материалах отсутствуют конкретные обоснования введения дополнительной меры контроля, а также неэффективности или недостаточности действующей системы регулирования.

Предположительно указанная необъективность проверок в рамках государственного надзора, по мнению разработчика, может быть связана с тем, что хозяйствующий субъект, ожидая предстоящую плановую проверку, имеет возможность к ней подготовиться, чтобы на момент проверки не могли быть выявлены нарушения природоохранного законодательства.

Однако в этой связи обращаем внимание, что экологический аудит также будет являться запланированной проверкой, в связи с чем хозяйствующий субъект имеет аналогичные возможности.

3. В качестве одного из объектов экологического аудита согласно пункту 1 статьи 4 проекта акта предлагается считать хозяйственную и (или) иную деятельность юридических лиц и индивидуальных предпринимателей, оказывающую НВОС.

При этом далее в статье 5 проекта акта перечисляется перечень случаев, в которых проводится обязательный экологический аудит. Например, указывается осуществление лицензируемых видов деятельности по обращению с отходами I - III классов опасности.

Обращаем внимание, что несмотря на отнесение деятельности по обращению с отходами к I и II категориям НBOC, по факту при соблюдении всех необходимых требований законодательства, проведении природоохранных мероприятий, использовании очистных сооружений негативное воздействие может отсутствовать.

В связи с этим требует уточнения круг субъектов, на которые будут распространяться требования рассматриваемого регулирования.

4. В целях обеспечения стимулирования хозяйствующих субъектов к проведению добровольного экологического аудита в случае выявле- 
ния соответствия объекта требованиям в области охраны окружающей среды пунктом 6 статьи 6 проекта акта предусматривается ряд стимулирующих мер.

Однако при этом в случае положительных итогов обязательного экологического аудита подобных мер не предусмотрено. Одновременно не предусмотрены действия ни хозяйствующих субъектов, ни уполномоченных органов в случае выявления по итогам аудита нарушений законодательства.

Таким образом, в проекте акта не устанавливается статус заключения обязательного экологического аудита.

При этом в пояснительной записке указывается, что данные, полученные в результате проведения экологического аудита, важны для обеспечения всестороннего обоснования управленческих решений в сфере охраны и рационального использования природных ресурсов, повышения качества окружающей среды и экологической безопасности экономического развития, что можно трактовать, например, таким образом, что заключение обязательного экологического аудита будет положено в основу принятия надзорным органом управленческого решения. Это отчасти подтверждает изложенную ранее в настоящем заключении позицию о пересечении с государственным экологическим надзором.

Вместе с тем итоги аудита предлагается включать в Государственный реестр заключений экологического аудита, данные которого необходимо будет размещать на официальном сайте уполномоченного Правительством Российской Федерации федерального органа исполнительной власти и на официальных сайтах органов исполнительной власти субъектов Российской Федерации в информационно-телекоммуникационной сети «Интернет».

Между тем практический смысл создания и ведения данного реестра, как и статус самих заключений, в нем размещаемых, в проекте акта не раскрываются. Таким образом, исходя из проектируемых положений можно сделать вывод о недостаточном обосновании создания реестра.

Учитывая изложенное, проект акта нуждается в детализации дальнейших действий сторон после подготовки заключения экологического аудита (как положительного, так и отрицательного). Также считаем необходимым предусмотреть в проекте акта соразмерные мероприятия по стимулированию как в случае добровольного экологического аудита, так и обязательного.

Полагаем, что заключение экологического аудита должно рассматриваться органами государственной власти как документ, подтверждающий соблюдение лицом, в отношении которого проведен аудит, требований законодательства в области охраны окружающей среды. 
5. Другой стороной проектируемых отношений являются экологические аудиторские организации и индивидуальные экологические аудиторы, которым проектом акта предписывается сложная многоступенчатая процедура подтверждения их соответствия статусу аудитора.

Статьей 11 проекта акта предполагается введение лицензирования экологической аудиторской деятельности.

Одновременно статьей 12 проекта акта предусматривается порядок аттестации экологического аудитора, который включает в себя сдачу квалификационного экзамена, стаж работы в области охраны окружающей среды не менее 5 лет, обучение по программам повышения квалификации в области экологического аудита раз в 2 года после получения квалификационного аттестата, переаттестацию раз в 5 лет.

Повторно обращаем внимание, что необходимость прохождения всех вышеперечисленных процедур может привести к существенному росту стоимости услуг экологических аудиторов. В конечном счете существует риск, что расходы хозяйствующих субъектов на проведение экологического аудита, осуществляющих деятельность, например, в сфере предоставления услуг населению (электроэнергетика, теплоснабжение, отходы), приведут к увеличению тарифов.

При этом считаем, что введение лицензирования экологической аудиторской деятельности требует дополнительной проработки.

Необходимо отметить, что аудиторская деятельность в целом с 2010 года не является лицензируемой с учетом возможности вступления аудиторских организаций, индивидуальных аудиторов в ассоциации, целью которых является саморегулирование их деятельности $<5>$.

Кроме того, с учетом специфики лицензируемых видов деятельности в положениях о лицензировании, как правило, указывается, например, необходимость наличия соответствующих установленным требованиям объектов (зданий, строений, сооружений), оборудования, работников определенной квалификации и необходимым стажем работы. Указанные требования сопряжены с материальными затратами, которые в том числе институционально направлены на предотвращение неправомерной деятельности лицензиата, поскольку такая деятельность будет сопряжена со значительными материальными убытками.

Однако представляется неопределенным, какие именно объекты должны принадлежать соискателю лицензии (экологическому аудитору) на праве собственности или на ином законном основании, и каким установленным требованиям они должны соответствовать.

Пунктом 1 статьи 8 проекта акта устанавливается право экологических аудиторских организаций и индивидуальных экологических ауди-

<5> Например, НП «Экологическая Аудиторская Палата» (http:// www.ecologyauditpalata.ru/). 
торов проводить необходимые для экологического аудита исследования и измерения (отбор и анализ проб воды, воздуха, почв).

При этом согласно пункту 3 статьи 3 проекта акта проведение лабораторных исследований и испытаний в рамках экологического аудита осуществляется государственными учреждениями, подведомственными федеральному органу исполнительной власти, уполномоченному на осуществление федерального государственного экологического надзора, аккредитованными в соответствии с законодательством Российской Федерации об аккредитации в национальной системе аккредитации.

Во-первых, данные положения, по сути, являются взаимоисключающими и в этой связи требуют уточнения.

Во-вторых, если руководствоваться пунктом 3 статьи 3 проекта акта, необходимость наличия лаборатории для проведения исследований и измерений у экологических аудиторских организаций исключается.

Вместе с тем полагаем данное решение необоснованным и ограничивающим, с одной стороны, возможность выбора субъектами регулирования иной лаборатории, с другой стороны, возможность участия в экологическом аудите аккредитованных в соответствии с законодательством Российской Федерации об аккредитации в национальной системе аккредитации испытательных лабораторий, имеющих необходимую область аккредитации.

Относительно иных вышеперечисленных возможных требованиях к соискателям лицензии, связанных с квалификацией работников, отмечаем, что данные вопросы уже урегулированы рассматриваемым проектом акта.

Учитывая изложенное, считаем необходимым исключить положения, обязывающие экологические аудиторские организации и индивидуальных экологических аудиторов получать лицензии.

Кроме того, следует учитывать, что проектируемая деятельность по проведению экологического аудита может рассматриваться в качестве инспекционной деятельности, которая может осуществляться организациями, аккредитованными в соответствии со стандартом ГОСТ Р ИСО/ МЭК 17020-2012. Национальный стандарт Российской Федерации. Оценка соответствия. Требования к работе различных типов органов инспекции. Системы экологического менеджмента предприятий при этом сертифицируются на соответствие стандарту ГОСТ Р ИСО 140012016. Национальный стандарт Российской Федерации. Системы экологического менеджмента. Требования и руководство по применению.

6. В целом отмечаем, что экологический аудит должен базироваться на добровольной основе. Его проведение должно иметь стимулирующий, а не принудительный характер, способствовать повышению кон- 
курентоспособности и рентабельности оказываемых аудиторских услуг с позиции роста экономической эффективности хозяйственной и природоохранной деятельности с целью формирования системы, способствующей эффективному решению проблематики по соблюдению норм экологического законодательства и предотвращению возможных нарушений в указанной сфере.

Полагаем, что при доработке проекта акта необходимо сконцентрироваться именно на развитии указанного механизма экологического аудита и внедрении в связи с этим дополнительных мер по стимулированию в форме, например, установления льготных тарифов платы за НВОС, кроме уже предусмотренных проектом акта.

Кроме того, введение дополнительных требований к хозяйствующим субъектам по проведению обязательного экологического аудита противоречит целям и принципам «регуляторной гильотины». Необходимо учитывать текущую экономическую и эпидемиологическую обстановку при введении требований, влекущих дополнительные, ранее не предусмотренные непроизводственные расходы.

7. Более того, учитывая многолетнюю разработку проекта акта (первое отрицательное Заключение было подготовлено в 2013 году) без каких-либо подтвержденных отрицательных последствий отсутствия предлагаемого регулирования в этот период, а также произошедшие изменения нормативной базы, целесообразность его разработки в текущей редакции требует соответствующего обоснования в сводном отчете.

На основе проведенной оценки регулирующего воздействия проекта акта Минэкономразвития России сделан вывод об отсутствии достаточного обоснования решения проблемы предложенным способом регулирования.

В проекте акта выявлены положения, вводящие избыточные обязанности, запреты и ограничения для физических и юридических лиц в сфере предпринимательской и иной экономической деятельности и способствующие их введению, а также положения, приводящие к возникновению необоснованных расходов физических и юридических лиц в сфере предпринимательской и иной экономической деятельности, а также бюджетов всех уровней бюджетной системы Российской Федерации.

Приложение: на 5 л. в 1 экз. 


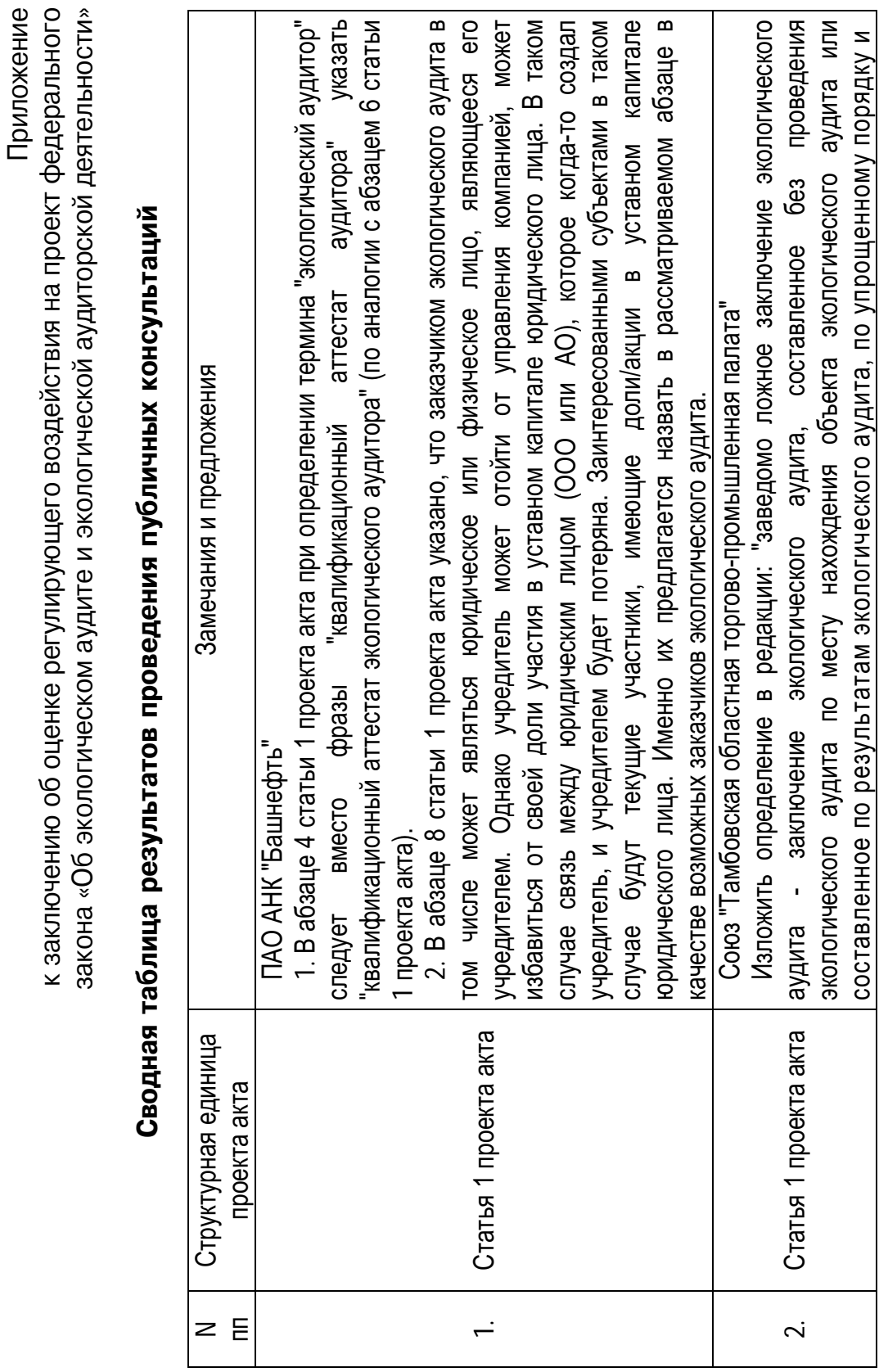




\begin{tabular}{|c|c|c|c|c|}
\hline 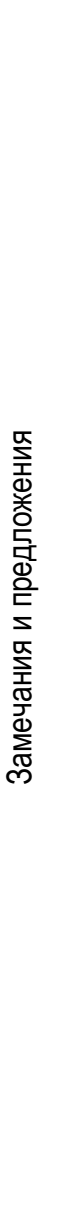 & 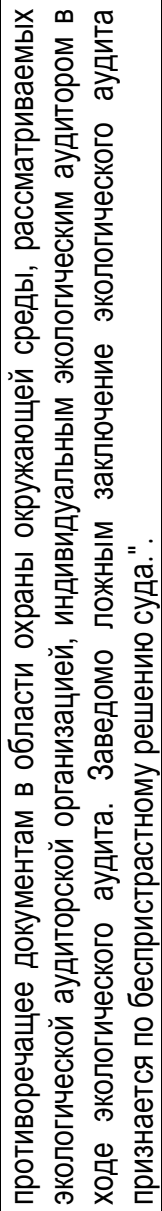 & 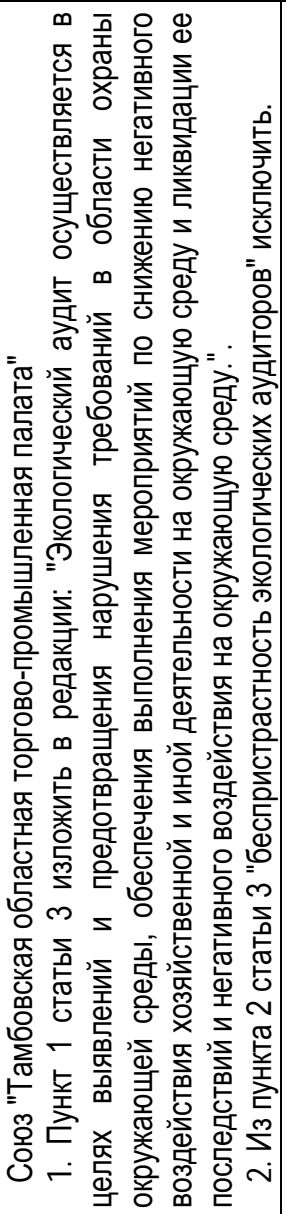 & 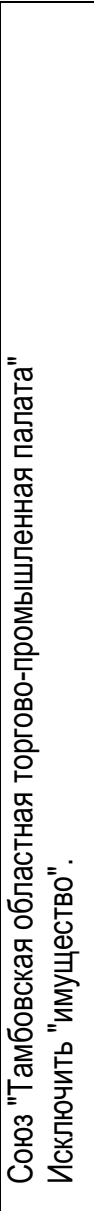 & 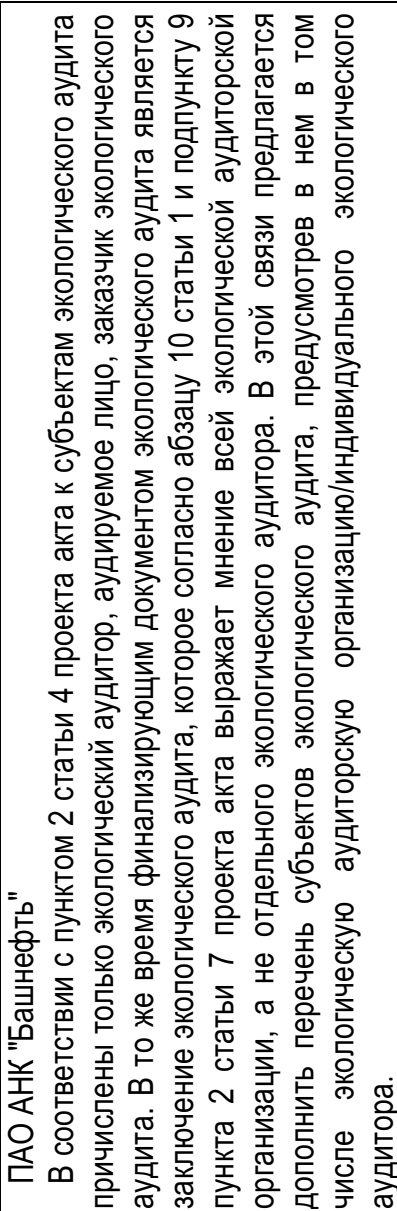 \\
\hline 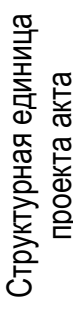 & & 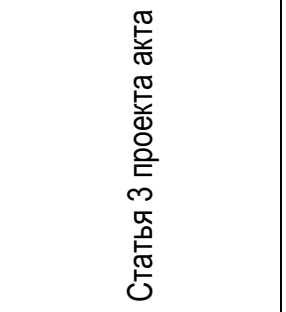 & 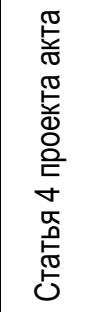 & 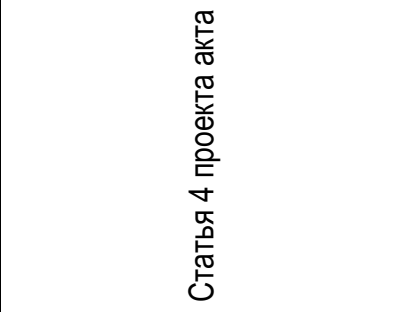 \\
\hline$z$ 듣 & & ம் & $\dot{\nabla}$ & 10 \\
\hline
\end{tabular}




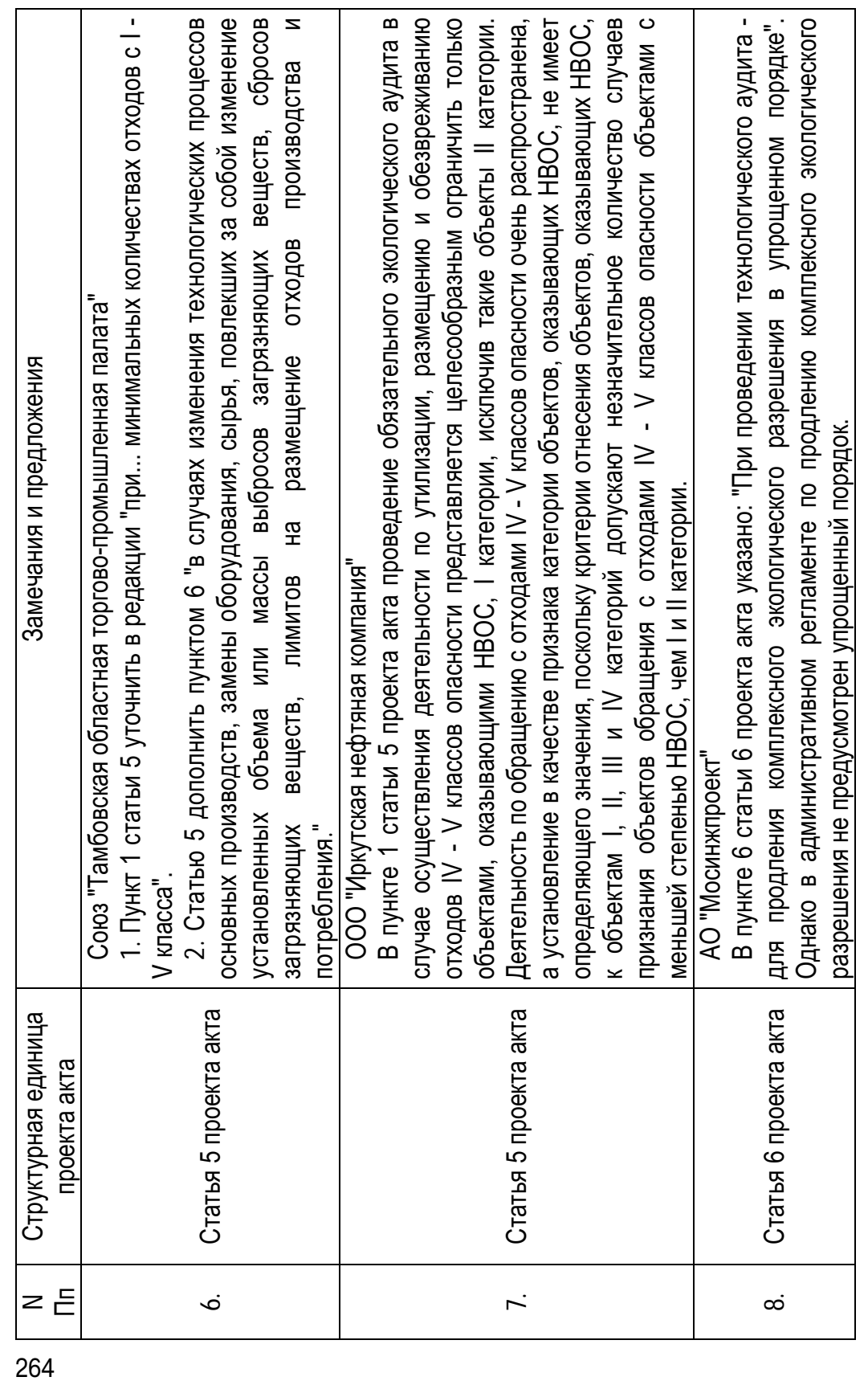




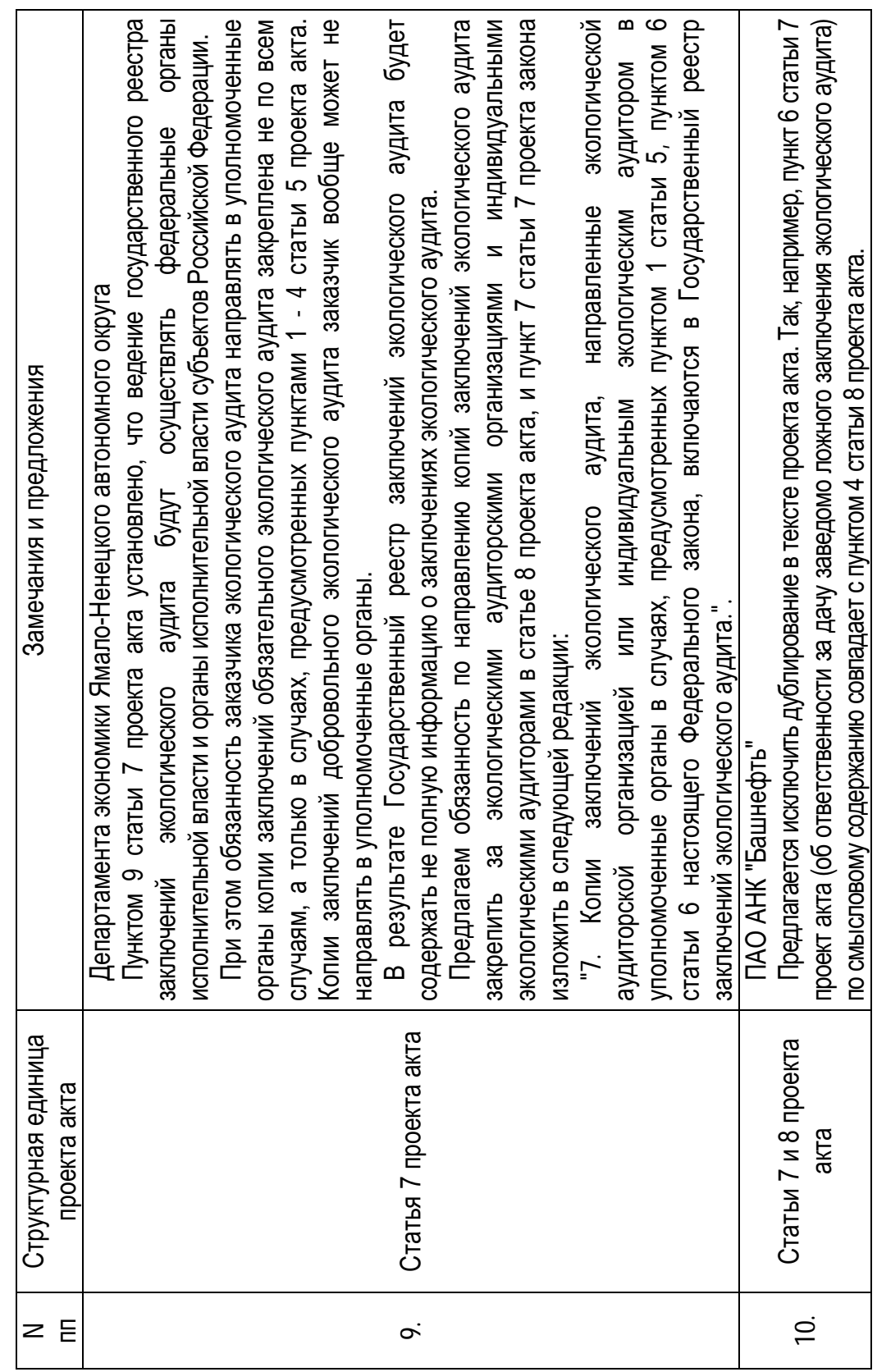




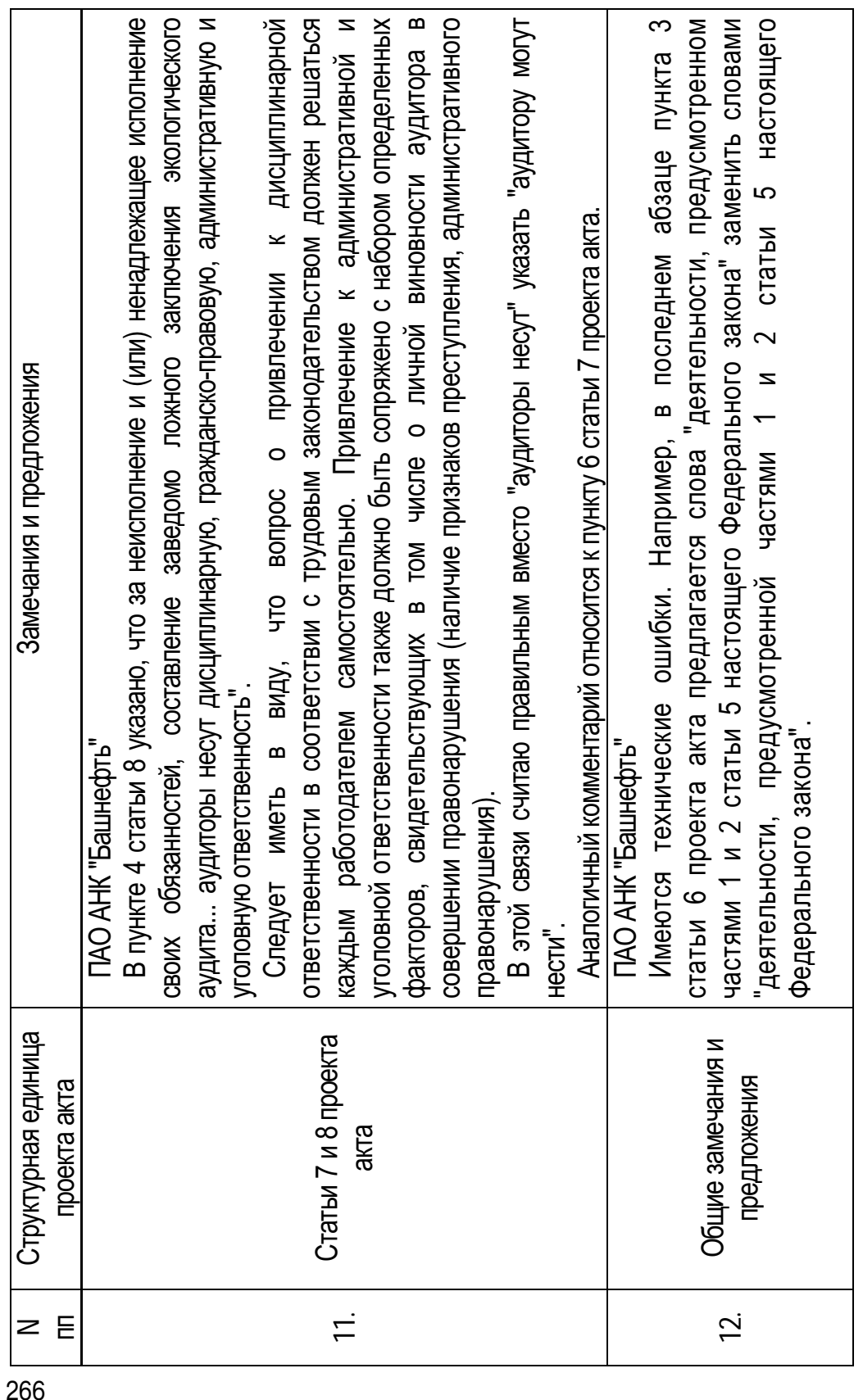




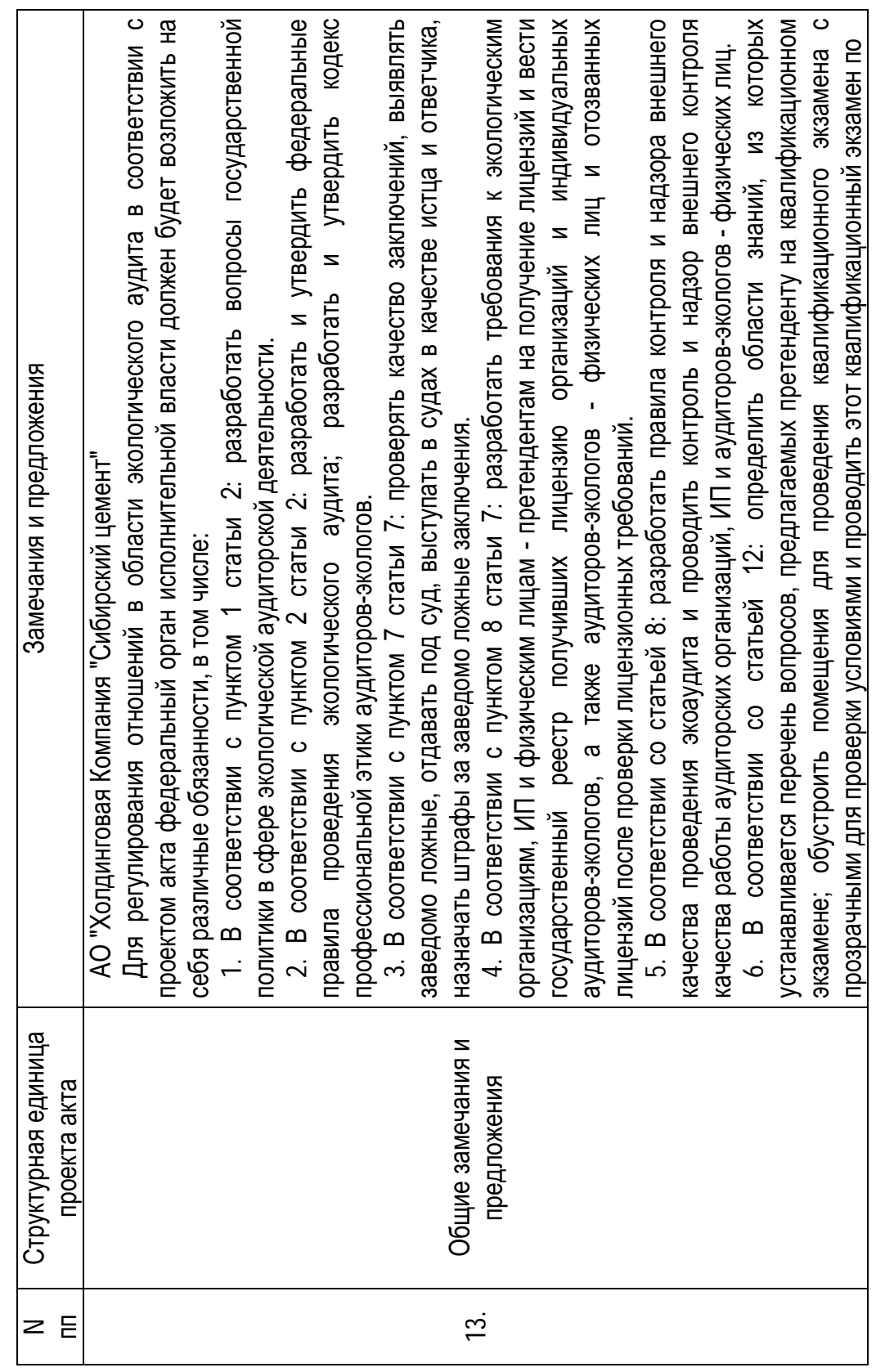




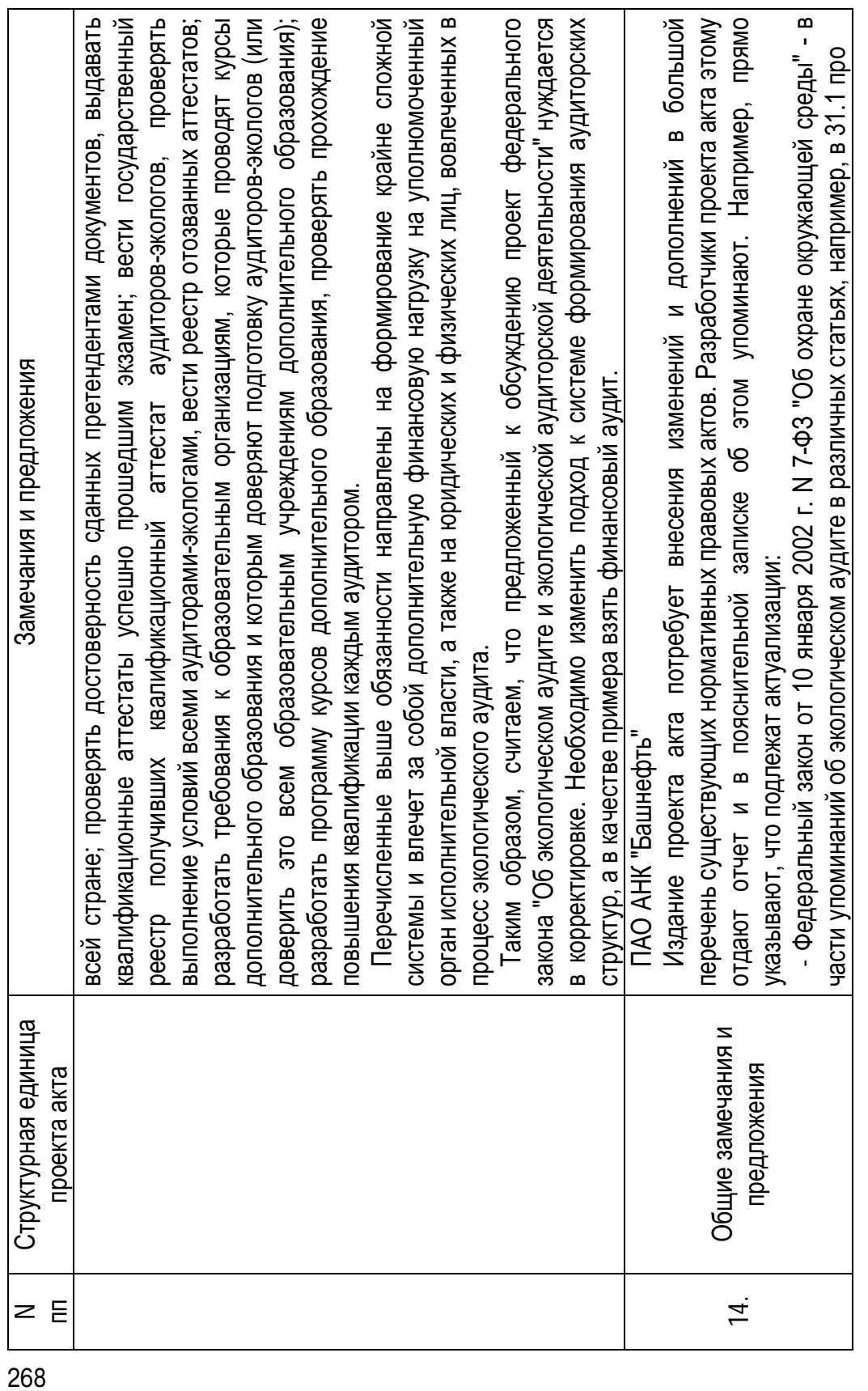




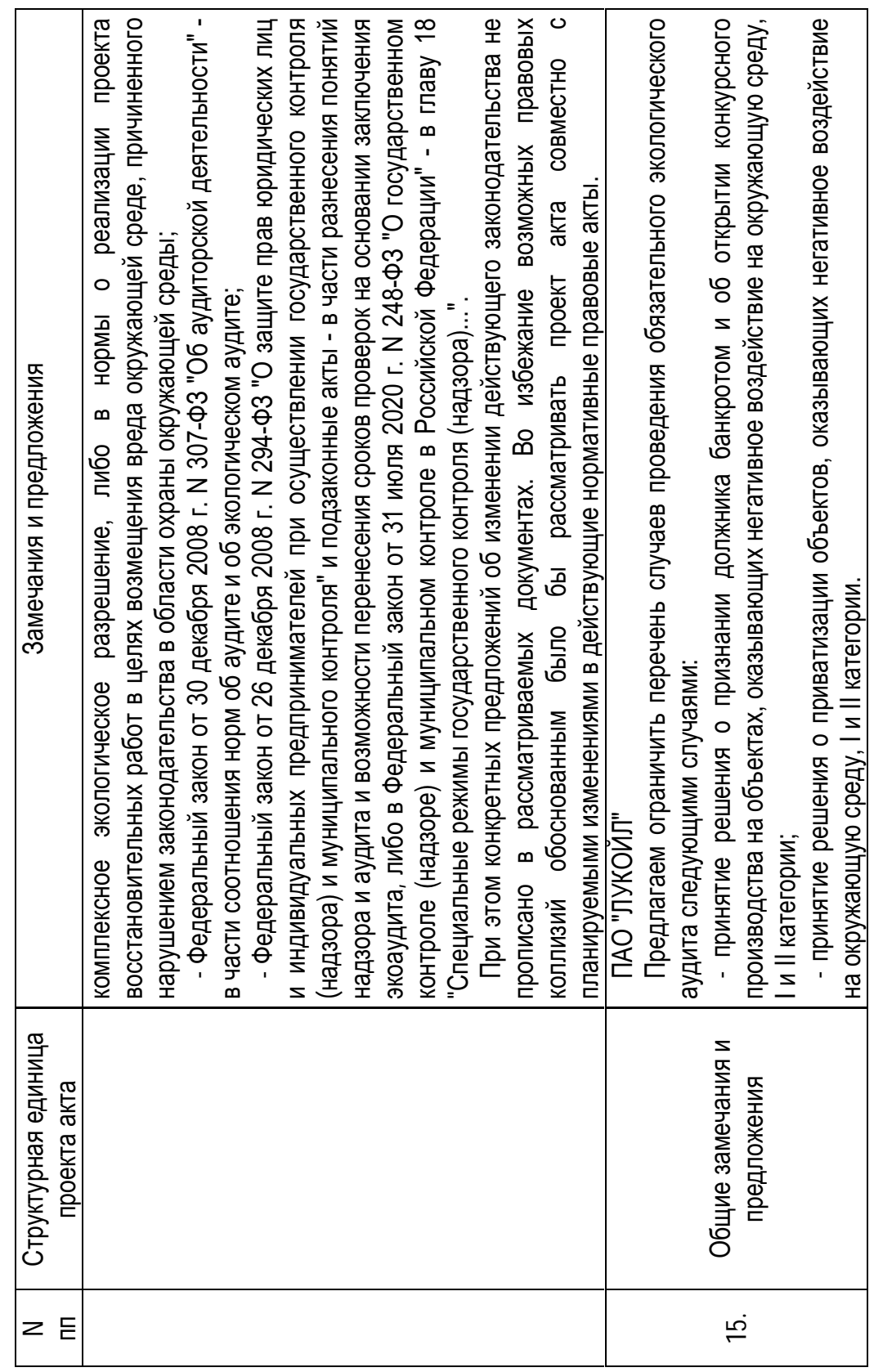




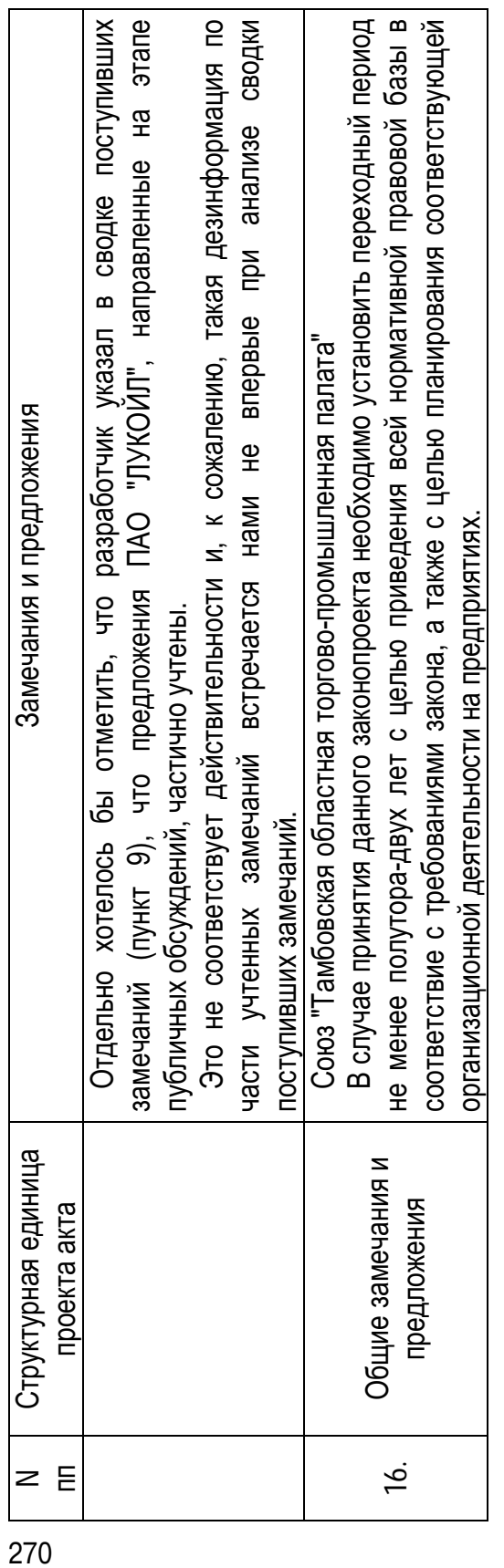


Приложение № 5

Утверждены распоряжением Правительства Российской Федерации OT №

(проект)

\title{
ПОДХОДЫ К ОЦЕНКЕ ВОЗДЕЙСТВИЯ ПРОЕКТОВ УСТОЙЧИВОГО (В ТОМ ЧИСЛЕ ЗЕЛЕНОГО) РАЗВИТИЯ В РОССИЙСКОЙ ФЕДЕРАЦИИ НА ОКРУЖАЮЩУЮ СРЕДУ И КЛИМАТ
}

\author{
Москва
}

2021

\section{Оглавление}

№ Наименование раздела Стр.

I. Общие положения

II. Основные направления оценки воздействия проектов развития на окружающую среду и климат

III. Порядок организации работ при проведении оценки проектов развития на окружающую среду и климат 6

IV. Заключение Верификатора 13

V Рекомендации по ведению реестров проектов развития 13

\section{I. Общие положения}

Настоящие подходы устанавливают подходы к оценке воздействия проектов устойчивого (в том числе зеленого) развития в Российской Федерации на окружающую среду и климат (далее соответственно - Модельные подходы, проекты развития).

1.1. Определения терминов «зеленый проект», «адаптационный проект», «зеленый финансовый инструмент», «адаптационный финансовый инструмент», «Инициатор», «верификация», «Верификатор», «Методологический центр ВЭБ.РФ» в Модельных подходах употребляются в значениях, определенных в Методических рекомендациям по отнесению финансовых инструментов к финансовым инструментам, направленным на финансирование «зеленых» или адаптационных проектов (далее - Методические рекомендации). 
1.2. Подходы к оценке воздействия проектов развития на окружающую среду и климат предназначены для Инициаторов проектов развития, консультантов, разработчиков проектной документации и ее разделов, верификаторов и иных участников, связанных с проектами развития.

1.3. Модельные подходы определяют базовые критерии и требования для верификации. Верификаторы на основании Модельных подходов разрабатывают собственные Подходы (далее - Подходы Верификатора), исходя из специфики заявленных Инициатором проектов развития. Подходы Верификатора с учетом всех вносимых в них изменений должны соответствовать положениям Модельных подходов и не противоречить им.

ПодходыВерификатора подлежат обязательной публикации на сайте Методологического центра ВЭБ.РФ в информационно-телекоммуникационной сети «Интернет».

1.4. Модельные подходы применяются для проведения верификации всех проектов развития, вне зависимости от планируемых мер поддержки проектов развития (включая финансовые и нефинансовые механизмы, меры государственной поддержки и иные меры).

1.5. Для целей применения Модельных подходовпонятие «проект развития» включает в себя «зеленые» и адаптационные проекты.

1.6. Верификаторы обязаны обеспечивать:

независимость своей деятельности по верификации от любого политического и (или) экономического влияния;

предотвращение, выявление в ходе своей деятельности по верификации конфликтов интересов, управление ими и раскрытие информации о них;

профессионализм и объективность при проведении верификации.

Верификатор обязан принимать меры по недопущению влияния на его суждение существующего или потенциального конфликта интересов Верификатора, его учредителей (акционеров, участников), работников и лиц, осуществляющих над ним контроль или оказывающих на него влияние. Верификатор обеспечивает выявление существующего или потенциального конфликта интересов, управление им и раскрытие информации о нем в случаях, если конфликт интересов может повлиять на суждения Верификатора.

1.7. Модельные подходы могут быть впоследствии пересмотрены по мере появления и распространения новых технологий, изменения критериев согласно ведущим российским и мировым практикам, изменения нормативно-правовой базы Российской Федерации, а также по результатам правоприменительной практики и результатам работы Верификаторов, исходя из специфики заявляемых Инициаторами проектов развития. 


\section{II. Основные направления оценки воздействия проектов развития на окружающую среду и климат}

2.1. Основные критерии отнесения проектов развития к «зеленым» проектам и адаптационным проектам.

2.1.1. К «зеленым» проектам относятсяпроекты, которые соответствуют целям и основным направлениям реализации «зеленых» проектов в Российской Федерации (Таксономии»зеленых» проектов) при условии достижения указанных в Таксономии «зеленых» проектов критериев по соответствующему направлению.

Таксономия «зеленых» проектов должна соответствовать:

а) Указу Президента Российской Федерации от 07.05.2018 № 204

«О национальных целях и стратегических задачах развития Российской Федерации на период до 2024 года», Указу Президента Российской Федерации от 21.07.2020 № 474 «О национальных целях развития Российской Федерации на период до 2030 года» В части национальной цели развития «Комфортная и безопасная среда для жизни», предусматривающей следующие целевые показатели:

ликвидация наиболее опасных объектов накопленного вреда окружающей среде и экологическое оздоровление водных объектов, включая реку Волгу, озёра Байкал и Телецкое;

снижение выбросов опасных загрязняющих веществ, оказывающих наибольшее негативное воздействие на окружающую среду и здоровье человека, в два раза;

создание устойчивой системы обращения с твердыми коммунальными отходами, обеспечивающей сортировку отходов в объеме 100 процентов и снижение объема отходов, направляемых на полигоны, в два раза;

повышение качества питьевой воды для населения, в том числе для жителей населенных пунктов, не оборудованных современными системами централизованного водоснабжения (при условии соблюдения критериев, установленных Верификатором);

сохранение биологического разнообразия (при условии соблюдения критериев, установленных Верификатором);

б) общественно значимым результатам, указанным в паспорте Национального проекта «Экология».

2.1.2. Допускается включение в Таксономию «зеленых» проектов иных направлений и критериев, не противоречащих пункту 2.1.1. настоящих подходов.

2.1.3. К адаптационным проектам относятся проекты, которые соответствуют целям и основным направлениям реализации адаптационных проектов в Российской Федерации (Таксономииадаптационных проектов) при условии достижения указанных в Таксономии адаптационных проектов критериев по соответствующему направлению. 
2.2. Основные экологические эффекты, на достижение которых направлен проект развития в результате своего внедрения и своей реализации.

Наименования основных экологических эффектов:

а) снижение выбросов загрязняющих веществ, включенных в перечень загрязняющих веществ, в отношении которых применяются меры государственного регулирования в области охраны окружающей среды, утвержденный распоряжением Правительства Российской Федерации от 08.07.2015 № 1316-р (далее - Перечень загрязняющих веществ),в атмосферный воздух стационарными источниками;

б) снижение выбросов парниковых газов (в пересчете на $\mathrm{CO}_{2}$-эквивалент);

в) снижение удельных выбросов загрязняющих веществ в атмосферный воздух от передвижных источников негативного воздействия на окружающую среду (например, в расчете на кВт/ч, тонно-километр, пассажирокилометр и другие);

г) повышение уровня использования исходных сырья и материалов

и снижение потребления материальных и энергетических ресурсов (электроэнергии, теплоэнергии, топлива и другие);

д) снижение потребления природных ресурсов;

е) сокращение удельных показателей образования отходов производства и потребления, в том числе за счет внедрения малоотходных и безотходных технологий (например, в расчете на м2 жилья, на единицу производимой продукции и другие) и снижение класса опасности отходов в источниках их образования;

ж) увеличение показателей утилизации отходов;

з) увеличение доли нормативно очищенных сточных вод в объеме сбрасываемых в поверхностные водные объекты сточных вод, требующих очистки, и снижение концентраций загрязняющих веществ, включенных в Перечень загрязняющих веществ, в воде водного объекта до предельно допустимого уровня,соответствующего назначению объекта, и ниже;

к) увеличениеплощади/протяженности восстановленных водных объектов;

л) увеличениепротяженности очищенной прибрежной полосы водных объектов;

м) увеличение площади лесовосстановления и лесоразведения;

н) увеличениеплощади территории, на которой восстановлено нарушенное состояние окружающей среды;

о) увеличениепоказателей сохранения биологического разнообразия. 


\section{III. Порядок организации работ при проведении оценки}

воздействия проектов развития на окружающую среду и климат

3. Порядок проведения Инициатором оценкивоздействия проектов развития на окружающую среду и климат.

3.1. Оценка воздействия проектов развития на окружающую среду и климат Инициатором состоит из следующих этапов:

\subsection{1. Определение экологического эффекта Инициатором.}

3.1.1.1. Экологический эффект определяется как разница между положительным и отрицательным экологическим эффектом, возникающими от реализации проекта развития.

3.1.1.2. Оценивается только экологический эффект напрямую связанный с реализацией проекта развития.

3.1.1.3. При определении экологического эффекта оценивается возможность его соответствия Таксономии «зеленых» проектов и Таксономии адаптационных проектов.

Неотъемлемым условием оценки является оценка экологического эффекта в отношении всех компонентов природной среды, при которой экологический эффект должен быть выше по сравнению со сценарием, при котором проект развития не будет реализован.

3.1.1.4. При определении экологического эффекта оцениваются:

а) целевые показатели достижения экологического эффекта (далее целевые показатели) - количественное значение показателей достижения экологического эффекта, которые планируется достичь в результате реализации проекта развития;

б) промежуточные показатели достижения экологического эффекта(далее - промежуточные показатели) - количественное значение показателя достижения экологического эффекта, который планируется достигнуть к определенному этапу реализации проекта развития.

в) фактический показатель достижения экологического эффекта(далее - фактический показатель) - количественное значение показателя достижения экологического эффекта, который достигнут к определенному этапу реализации проекта развития, а также количественное значение показателя достижения экологического эффекта, который достигнут после завершения периода реализации проекта развития (с учетом сроков достижения экологического эффекта, предусмотренных проектом развития).

3.1.1.5. Целевые и промежуточные показатели устанавливаются для каждого выбранного Инициатором наименования экологического эффекта, определенных в пункте 2.2 настоящих подходов. По проекту развития для каждого наименования экологического эффекта может быть определено несколько экологических эффектов.

3.1.1.6. Оценка обоснованности целевых, промежуточных и фактичес- 
кихпоказателей является составляющей процесса определения соответствия проекта развития предъявляемым требованиям.

3.1.1.7. Недостижение целевых показателей или промежуточныхпоказателей является основанием для пересмотра решения о соответствии проекта развития предъявляемым требованиям. При этом может допускаться отклонениев части достигнутых фактических показателей, не приводящее к пересмотру решения о соответствии проекта развития предьявляемым требованиям. Рекомендуемый допустимый размер такого отклонения (в меньшую сторону):5 \% от значения промежуточных показателей и $3 \%$ от значения целевых показателей.

В случае установления несоответствий целевых или промежуточных показателям на этапе реализации проекта развития Верификатор и Инициатор проекта развития могут разработать и согласовать план корректирующих мероприятий и провести повторную верификацию экологического эффекта проекта развития.

\subsection{2. Оценка экологического эффекта Инициатором.}

3.1.2.1. Целевыепоказатели определяется Инициатором на этапе подготовки проекта развития и подачи заявки на проведение верификации соответствия проекта развития предъявляемым требованиям с приложением обоснованного расчета.

Результаты расчета целевыхпоказателей проекта развития

с обосновывающими материалами перед началом реализации проекта развития направляются Верификатору.

3.1.2.2. Фактические показатели определяются Инициатором после окончания этапа проекта развития или завершения реализации проекта развития. Сведения о достижении фактических показателей представляется Верификатору в виде экологической отчетности, включающей расчетыи обосновывающие материалы, включая финансовую отчетность о реализации проекта развития (далее - экологическая отчетность).

3.1.2.3. Экологическая отчетность основываются на анализе прямого и косвенного экологического эффекта от реализации проекта развития.

Формы экологической отчетности определяются Верификатором.

4. Порядок проведения Верификатором оценкивоздействия проекта развитияна окружающую среду и климат.

\section{1. Порядок проведения Верификатором предварительной оцен- ки заявленного проекта развития. \\ С учетом специфики проекта развития Верификатор должен проверить наличие, а также оценить заявленные Инициатором (в случае, если это при- менимо к конкретному проекту развития): \\ а) ключевые параметры и результаты проекта развития; \\ б) параметры производимого, приобретаемого или внедряемого в рам- ках проекта развития оборудования и технологий;}


в) параметры технологических процессов и производства;

г) отраслевые методы и методики, которые были использованы

при расчете экологического эффекта; методологии и допущения, используемыепри определении целевых экологическихэффектов;

д) оценить соответствие данных измерений и учета показателей выбросов загрязняющих веществ, парниковых газов, сбросов загрязняющих веществ, концентраций загрязняющих веществ, объемов (массы) образования и утилизации отходов, учета природных и иных ресурсов. Удостовериться, что измерения проведены сертифицированным оборудованием, аккредитованными и аттестованными лабораториями;

е) достаточность предоставленных Инициатором документов для оценки экологического эффекта от реализации проекта развития, включая выявление потенциальных негативных факторов,влияющих на достижение экологического эффекта от реализации проекта развития;

ж) комплект разрешительной документации в области охраны окружающей среды,результат проведения государственной экологической экспертизы (в случае, если необходимость проведения такой экспертизы предусмотрено действующим законодательством);

3) локальные акты Инициатора в сфере охраны окружающей среды, экологические документы, экологическую отчетность, включая финансовую отчетность и информацию в области экологической ответственности в рамках публичной нефинансовой отчетности, выпускаемой Инициатором в целях определения соответствия проекта развития предъявляемым требованиям;

и) обоснованность и достаточность выбранного экологического эффекта, по которомубудет оцениваться проект развития;

к) обоснованность и достаточность выбранных промежуточных, фактических и целевых показателей, а также правильность их расчетов;

л) отчет «Оценка воздействия заявляемого проекта развития

на окружающую среду и климат» (далее - Отчет), который должен содержать в себе прогнозную оценку потенциально значимых воздействий на окружающую среду и климат в проекте планируемой или осуществляемой хозяйственной и (или) иной деятельности, а также содержать рекомендации по мероприятиям, которые предотвращают и/или смягчают выявленные негативные воздействия на окружающую среду и климат.

В Отчет рекомендуется включить следующие разделы:

- общие сведения о проекте планируемой или осуществляемой хозяйственной

и (или) иной деятельности;

- оценка текущего состояния компонентов окружающей среды в предполагаемом месте реализации проектапланируемой или осуществляемой хозяйственной и (или) иной деятельности, включая состояние атмосферно- 
го воздуха, почвенных, земельныхи водных ресурсов, а также растительности, животного мира, особо охраняемых природных территорий;

- описание климатических, геологических, гидрологических, ландшафтных условий на территории предполагаемой зоны влияния проектапланируемой или осуществляемой хозяйственной и (или) иной деятельности;

- оценкатекущего состояния здоровья населенияс учетом воздействия экологических факторов, социально-экономическая характеристика территории;

- анализ законодательных требований по охране окружающей среды

к строительству и эксплуатации в рамках заявляемого Инициатором проекта развития;

- информация о характере и масштабах потенциального воздействия

на окружающую среду и климатпланируемой или осуществляемой хозяйственной и (или) иной деятельности, оценке экологическихи связанных с ними социально-экономических и иных последствий этого воздействия и их значимости, возможности минимизации воздействий;

- рекомендации по предотвращению или минимизации выявленного негативного воздействия на окружающую среду и климат. Составление предложений по проведению экологического мониторинга и производственного экологического контроля;

- анализ неопределенностей и ограничений в определении воздействия на окружающую среду, рекомендации по их устранению;

- информация овыявленныхнегативныхфакторах,влияющих

надостижениеэкологическогоэффектаот реализации проекта развития,и мерах поихсмягчению или компенсации:

- эколого-экономическоеобоснование целевыхи промежуточных показателей;

- эколого-экономическая оценка реализации проекта развития;

- выводы.

4.1.1. Обоснованность и достаточность выбранного экологического эффекта, по которому будет оцениваться проект развития, а также правильностьего расчета:

4.1.1.1. Проводится Верификатором:

а) на этапе перед принятием решения о признании проекта развития, заявленного Инициатором, соответствующим предъявляемым требованиям (соответствует этапу «а» и/или этапу «б» пункта 17 Методических рекомендаций);

б) на этапе промежуточных верификаций при достижении Инициатором промежуточных экологических эффектов (соответствует этапу «б» или этапу «в»пункта 17 Методических рекомендаций);

в) на заключительном этапе проекта развития (соответствует этапу «в» пункта 17 Методических рекомендаций). 
4.1.1.2. Определяется Верификатором на основе оценки обоснованности представленных расчетов и прилагаемых к ним материалов.

Для оценки обоснованности расчетов Верификатор вправе запросить дополнительные расчеты и документы, обосновывающие представленные расчеты соответствующих показателей.

Указанные запросы формируются Верификатором исходя из необходимости оценки соблюдения Инициатором требований действующего законодательства при реализации проекта развития, в том числе в части соблюдения требований об оценке воздействия на окружающую среду в отношении планируемой и осуществляемой хозяйственной и иной деятельности, которая может оказать прямой или косвенный эффект на окружающую среду, а также проведения государственной экологической экспертизы, отсутствия аварий и катастроф при реализации проектов развития, воздействия на население и иных требований.

4.1.1.3. Может быть оценена посредством выезда Верификатора на место реализации проекта развития, а также посредством направления в контрольно-надзорные органы в соответствии с их компетенцией и (или) отраслевые научные и экспертные организации, запросов в рамках межведомственного информационного взаимодействия или запросов на бумажном носителе (далее - Запросы).

4.1.2. После проведения верификации Верификатор формирует Раздел Заключения (в соответствии с разделом V Модельных подходов).

В случае если Верификатором при проведении оценки экологического эффекта выявлены несоответствия сведений, представленных Инициатором в представленных расчетах и обосновывающих материалах к ним, сведениям, имеющимся у Верификатора и (или) полученным им путем направления Запросов, в частности, полученным сведениям о том, что при реализации проекта развития Инициатором допущены нарушения требований законодательства в области охраны окружающей среды, то Верификатор направляет Инициатору Заключение онесоответствиипроекта развития предъявляемым требованиям.

\section{2. Порядок проведения Верификатором оценки достижения промежуточных экологических эффектов в ходе реализации про- екта развития.}

Верификатор должен проверить наличие и оценить предоставленные Инициатором:

а) экологическую отчетность о достижении заявленных промежуточных экологических эффектов;

б) результаты (акты, заключения, предписания, представления)контрольно-надзорных мероприятий в сфере охраны окружающей среды, проведенных в период реализации проекта развития. 
4.2.1. По результатам проведения верификации Верификатор формирует Заключение (в соответствии с разделом V Модельных подходов).

В случае если Верификатором при проведении оценки экологического эффекта выявлены несоответствия сведений, представленных Инициатором в представленных расчетах и обосновывающих материалах к ним, сведениям, имеющимся у Верификатора и (или) полученным им путем направления Запросов, в частности, полученным сведениям о том, что при реализации проекта развития Инициатором допущены нарушения требований законодательства в области охраны окружающей среды, то Верификатор направляет Инициатору Заключение онесоответствиипроекта развития предъявляемым требованиям.

Недостижение промежуточных показателей (с учетом допустимых отклонений, указанных в п. 3.1.1.7 Модельных подходов) является основаниемдля пересмотра решения о соответствии проекта развития предъявляемым требованиям.

\section{3. Порядок проведения Верификатором оценки достижения- фактических экологических эффектов после завершения реализа- ции проекта развития.}

4.3.1. Врамкахопределениясоответствияпроекта развития предъявляемым требованиям,на заключительном этапе проекта развития Верификатороценивает:

а) заключения уполномоченных контрольно-надзорных органов

о выполнении Инициатором мероприятий по охране окружающей среды (при наличии);

б) заключения уполномоченных контрольно-надзорных органов

о соответствии проекта развития проектной документации;

в) обоснование и расчет достижения Инициатором фактических показателей и их соответствие заявленным целевым показателям.

4.3.2. По результатам проведения верификации Верификатор формируетитоговое Заключение (в соответствии с разделом V Модельных подходов).

В случае если Верификатором при проведении оценки экологического эффекта выявлены несоответствия сведений, представленных Инициатором в представленных расчетах и обосновывающих материалах к ним, сведениям, имеющимся у Верификатора и (или) полученным им путем направления Запросов, в частности, полученным сведениям о том, что при реализации проекта развития Инициатором допущены нарушения требований законодательства в области охраны окружающей среды, то Верификатор направляет Инициатору Заключение онесоответствиипроекта развития предьявляемым требованиям.

Недостижение целевых показателей (с учетом допустимых отклонений, указанных в п. 3.1.1.7 Модельных подходов) и/или нарушение обязательных требований Федерального закона от 10.01.2002 № 7-Ф3 «Об охране 
окружающей среды» являются основанием для пересмотра решения о соответствии проекта развития предъявляемым требованиям.

В таком случае Верификатор направляет Инициатору Заключение о несоответствии проекта развития предъявляемым требованиям.

4.4. При оценке воздействия проектов развития на окружающую среду и климат в своей работе Верификатор должен руководствоваться перечнем нормативных правовых актов, публикуемым Минприроды России на своем официальном сайте в информационно-телекоммуникационной сети «Интернет».

4.5. Оценка климатических факторов и расчет выбросов парниковых газов осуществляется с учетом требований законодательства Российской Федерации и институтов Рамочной конвенции по изменению климата ООН.

Расчет выбросов парниковых газов ведется в соответствии с Методическими указаниями и руководством по количественному определению объема выбросов парниковых газов организациями, осуществляющими хозяйственную и иную деятельность в Российской Федерации.

\section{V. Заключение Верификаторав части оценки воздействия проектов развития на окружающую среду и климат}

5.1. При формировании ЗаключенияпоитогампроведенияверификацииВерификаторвключает в него раздел по оценке воздействия проекта развития на окружающую среду и климат (далее- Раздел Заключения) с указанием выводово соответствии или несоответствиипроекта развития предъявляемым требованиям.

Заключение не выдается в случае непредставления или неполного представления Верификатору документов и сведений, предусмотренных Модельными подходами и необходимых для проведения оценки воздействия проекта развитияна окружающую среду и климат.

5.2. Приложение кРазделу ЗаключенияВерификаторадолжно содержать документы и материалы, обосновывающие вывод Верификаторао соответствии проекта развития предъявляемым требованиям с учетом положений настоящих подходов.

Без указанного приложения Заключение считается недействительным.

5.3. Верификаторы направляют все выпущенныеЗаключения в Минприроды России.

5.4. Минприроды России ведет реестр Разделов Заключений и публикует Разделы Заключений (при выдачеположительного Заключения)на своем официальном сайте в информационно-телекоммуникационной сети «Интернет».

5.5. Ответственность за достоверность данных, предоставленных Инициатором Верификатору, несет Инициатор.

Ответственность за выводы, включенные в Раздел Заключения, несет Верификатор. 


\section{Все книги серии «Административная и бюджетная реформы на современном этапе"}

\section{Яковенко Д.А.}

Некоторые проблемы реформирования бухгалтерского учета в общественном (государственном и муниципальном) секторе: конвергенция с международными стандартами. Построение комплексной системы учета в органе исполнительной власти и подведомственных учреждениях / Д.А.Яковенко. - Самара, Самар. территориальный ин-т проф. бухгалтеров, 2006. - 387 с. - (Серия «Административная и бюджетная реформы на современном этапе»; Вып.1)

ISBN 5-94928-010-5

Предлагаемое издание открывает серию публикаций и знакомит читателя с результатами научно-исследовательских работ и методическими разработками в рамках реализации ключевых положений административной и бюджетной реформ. Монография обращается к проблемам реформирования бухгалтерского учета в общественном (государственном и муниципальном) секторе с учетом провозглашенного Минфином РФ сближения с Международными стандартами отчетности в общественном секторе (IPSAS). В монографии даются рекомендации по организации учета при наличии последующей консолидации отчетности, по разработке принципов учетной политики (в т.ч. по нетиповым формам учета), по проблемам квалификации бухгалтерских кадров и др.

Монография рассчитана на руководителей органов государственной власти и местного самоуправления.

Yakovenko D.A. Some problems of accounting reforming in public (state and municipal) sector: convergence with international standards. Construction of account complex system in executive authority and subordinated establishments

Series: Administrative and budget reforms at the present stage. Issue 1. - Samara, The Institute of Professional Accountants of Samara Region, 2006, page 387.

The offered edition opens a series of publications and acquaints the reader with results of research works and methodical workings out within the limits of realisation of key positions of administrative reform. The monography is prepared as the practical grant on transformation of the state (municipal) budgetary establishments to the state (municipal) independent establishments. The monography is calculated on heads of public authorities and local government. The monograph addresses the issues of budget accounting reforming, and in particular to the implementation of IPSASs in Russia. The monograph provides recommendations on particular aspects of accounting policies of budget organisation, on forms of initial accounting recognition and schedules of accounting departments work.

The monography is made for heads of public authorities and local government. 


\section{Яковенко Д.А.}

Регламентация государственных функций и услуг на примере спортивной отрасли / Д.А.Яковенко; Самар. территориальный ин-т проф.бухгалтеров, Гильдия финансистов, Поволжск. ин-т повышения квалификации финансовых работников. Самара, Самар. территориальный ин-т проф. бухгалтеров, 2008. - 271 с. - (Серия «Административная и бюджетная реформы на современном этапе»; Вып.2)

ISBN 978-5-94928-011-9

Предлагаемое издание продолжает серию публикаций и знакомит читателя с результатами научно-исследовательских работ и методическими разработками в рамках реализации ключевых положений административной реформы. Монография подготовлена как практическое пособие по реализации положений административной реформы в части порядка подготовки, утверждения и внедрения административных регламентов исполнения государственных функций и государственных услуг на примере органов власти, регулирующих правоотношения в спортивной отрасли. Монография рассчитана на руководителей органов государственной власти и местного самоуправления.

\section{Dmitry A. Yakovenko. Regulation of governmental functions on example of sports segment.}

Series: Administrative and budget reforms at the present stage. Issue 2. Samara, The Institute of Professional Accountants of Samara Region, 2008, page 271.

This issue is a continuation of the series and provides the reader with the results of scientific and research work and methodological developments obtained from the accomplishment of the key aspects of administrative reform. The monograph is made as a practical workbook for administrative reform accomplishment; in particular it will be useful for preparation, approval and implementation of administrative normative for governmental functions and provision of services by the government. As an example the governmental bodies responsible for sports were taken.

Target group of this monograph are top officials of the state, regional and local governments. 


\section{Яковенко Д.А.}

Методические рекомендации по преобразованию государственных (муниципальных) бюджетных учреждений в государственные (муниципальные) автономные учреждения (на примере города Москвы) / Д.А.Яковенко; Самар. территориальный ин-т проф.бухгалтеров, Гильдия финансистов, Поволжск. ин-т повышения квалификации финансовых работников. - Самара, Самар. территориальный ин-т проф. бухгалтеров, 2009. - 219 с. (Серия «Административная и бюджетная реформы на современном этапе»; Вып.3)

ISBN 978-5-94928-012-6

Предлагаемое издание продолжает серию публикаций и знакомит читателя с результатами научно-исследовательских работ и методическими разработками в рамках реализации ключевых положений административной реформы. Монография подготовлена как практическое пособие по преобразованию государственных (муниципальных) бюджетных учреждений в государственные (муниципальные) автономные учреждения. Монография рассчитана на руководителей органов государственной власти и местного самоуправления.

Dmitry A. Yakovenko. Methodical recommendations about transformation of the state (municipal) budgetary establishments in the state (municipal) budgetary independent establishments (on an example of a city of Moscow).

Series: Administrative and budget reforms at the present stage. Issue 3. Samara, The Institute of Professional Accountants of Samara Region, 2009, page 219.

The offered edition continues a series of publications and acquaints the reader with results of research works and methodical workings out within the limits of realisation of key positions of administrative reform. The monography is prepared as the practical grant on transformation of the state (municipal) budgetary establishments to the state (municipal) independent establishments. The monography is calculated on heads of public authorities and local government. 


\section{Яковенко Д.А.}

Бюджетирование и управление, ориентированные на результат, на примере органов исполнительной власти и бюджетных учреждений спортивной отрасли / Д.А.Яковенко; Самар. ин-т проф.бухгалтеров, аудиторов, финансовых менеджеров и экономистов, Гильдия финансистов, Поволжск. ин-т повышения квалификации финансовых работников. - Самара, Самар. ин-т проф.бухгалтеров, аудиторов, финансовых менеджеров и экономистов, 2009. - 383 с. - (Серия «Административная и бюджетная реформы на современном этапе»; Вып.4)

ISBN 978-5-94928-013-3

Настоящее методическое пособие подготовлено в рамках реализации бюджетной и административной реформ, проводимых в Российской Федерации в части внедрения бюджетирования и управления, ориентированных на результат.

Пособие может быть использовано для разработки комплексных показателей (индикаторов) оценки деятельности, повышения результативности и эффективности, внедрения методов результативного управления в отраслевых и функциональных органах государственной власти и местного самоуправления и (или) в подведомственной сети бюджетных учреждений, оказывающих услуги населению и юридическим лицам.

\section{Yakovenko D.A. Budgeting and management focused on result an example of enforcement authorities and budgetary establishments of sports branch.}

Series: Administrative and budgetary reforms at the present stage. Issue 4. Samara, The Institute of Professional Accountants of Samara Region, 2009, page 383.

The present methodical grant is prepared within the limits of realisation budgetary and administrative reforms spent in the Russian Federation regarding introduction of budgeting and management, focused on result.

The grant can be used for working out of complex indicators of an estimation activity, increase of productivity and efficiency, introduction of methods of productive management in branch both functional public authorities and local government and (or) in a subordinated network of the budgetary establishments rendering services to the population and legal bodies. 


\section{Яковенко Д.А.}

Спортивно-образовательные государственные услуги: классификация, паспортизация и стандартизация. Государственное (муниципальное) задание на исполнение услуг. / Д.А. Яковенко. - Самара, Самар. ин-т проф. бухгалтеров, аудиторов, финансовых менеджеров и экономистов, 2009. - 299 с. - (Серия «Административная и бюджетная реформы на современном этапе»; Вып.5)

ISBN 978-5-94928-014-0

Ориентация деятельности органов исполнительной власти на интересы пользователей являются основной целью административной реформы. Отсутствие стандартов на многие государственные услуги, не позволяет упорядочить и конкретизировать обязательства органов исполнительной власти перед обществом, внедрить объективные процедуры контроля и оценки их деятельности, то есть препятствует повышению качества деятельности органов исполнительной власти. На сегодня нормативно-правовая база стандартизации услуг органов исполнительной власти разработана недостаточно. Крайне неэффективна существующая система обратной связи с потребителями государственных услуг. Необходимо осуществить внедрение стандартов государственных услуг и обеспечивающих их соблюдение, а также эффективное исполнение иных полномочий органов исполнительной власти. Стандарты услуг позволят упорядочить и конкретизировать обязательства органов исполнительной власти перед гражданами и организациями, внедрить объективные процедуры контроля и оценки их деятельности, снизить дефицитность услуг, значимых для граждан. Стандарты создаются для государственных услуг, закрепленных в реестрах государственных услуг, согласованных с требованиями законодательства и реестрами расходных обязательств бюджетов. Только по стандартизованным услугам возможно разрабатывать государственное задание, и, самое главное, эффективно контролировать его исполнение.

В настоящих методических рекомендациях определен порядок действий органов исполнительной власти по созданию реестров, паспортов и стандартов государственных услуг и разработке на их основе государственного задания.

\section{Yakovenko D.A. Sport and Educational Public Services: Classification, Certification and Standardization. Sport and Educational Public Services: Classification, Certification and Standardization. State (municipal) order for service provision}

Series:" "Administrative and budgetary reforms at the present stage»; Vol. 5Samara: National Institute of Professional Accountants, Financial Managers and Economists, 2009, p. 299.

Executive authorities focusing on public services users is the main objective of administrative reform. Lack of standards for many public services does not allow to streamline and specify the obligations of executive authorities to the public, as well as to introduce the procedures of objective control and assessment of their activities, i.e. it impedes the improvement of executive authorities' performance. At the moment, the regulatory and legal framework for the standardization of the executive authorities' services is insufficiently developed. The existing system of feedback from consumers of public services is extremely inefficient. It is necessary to implement standards of public services and ensure their compliance, along with the effective execution of other powers of executive authorities. Standards of public services will streamline and specify obligations of executive authorities to citizens and organizations, introduce objective procedures of control and assessment of their performance, reduce the scarcity of services that are important to citizens. Standards are created for public services fixed in the registers of public services, agreed with the requirements of legislation and registers of budget expenditure commitments. It is only possible to develop the state order for standardized services, and, most importantly, to effectively monitor its performance.

The present methodological recommendations define the procedure for executive authorities to create registers, certificates and standards for public services, and development of the state order based on them. 


\section{Яковенко Д.А.}

Методические рекомендации по оптимизации сети учреждений бюджетной сферы и смене типа бюджетных учреждений (на примере учреждений Самарской области) / Д.А. Яковенко, М.Д. Яковенко ; Национальный ин-т проф. бухгалтеров, финансовых менеджеров и экономистов. - Самара, Самар. территориальный ин-т проф. бухгалтеров, 2010. - 259 с. - (Серия «Административная и бюджетная реформы на современном этапе»; Вып.6)

ISBN 978-5-94928-015-7

Предлагаемое издание продолжает серию публикаций и знакомит читателя с результатами научно-исследовательских работ и методическими разработками в рамках реализации ключевых положений административной и бюджетной реформ. Монография подготовлена как практическое пособие по смене типа государственных (муниципальных) учреждений в рамках реализации положений федерального закона № 83-Ф3 от 08.05.2010 г. «О внесении изменений в отдельные законодательные акты Российской Федерации в связи с совершенствованием правового положения государственных (муниципальных) учреждений». Монография рассчитана на руководителей органов государственной власти и местного самоуправления и руководителей учреждений бюджетной сферы.

\section{Dmitry A. Yakovenko, Mstislav Yakovenko}

Guidelines for optimizing the network of public sector and changing the type of public institutions (for example, institutions of the Samara Region, Russia).

Series: Administrative and budget reforms at the present stage. Issue 6. Samara, The Institute of Professional Accountants of Samara Region, 2010, page 259.

This monograph continues the series of publications on the results of research and methodological developments in the implementation of administrative and fiscal reforms. The monograph was prepared as a practical guide on change of the type of state (municipal) institutions in the implementation of the Federal Law № 83-FZ from 08.05.2010 «On Amendments to Certain Legislative Acts of the Russian Federation in connection withthe improvement of the legal status of state (municipal) institutions". The monograph is intended for heads of state bodies and local self-government and the leaders of public sector institutions. 


\section{Яковенко Д.А.}

Особенности формирования государственного (муниципального) задания для функциональных учреждений (на примере учреждений спортивной отрасли) / Д.А. Яковенко, П.А. Лыков. - Самара, Национальный ин-т проф. бухгалтеров, финансовых менеджеров и экономистов, 2010. - 88 с. (Серия «Административная и бюджетная реформы на современном этапе»; Вып.7)

Настоящее методическое пособие подготовлено в рамках реализации бюджетной и административной реформ, проводимых в Российской Федерации в части внедрения бюджетирования и управления, ориентированных на результат.

Целевая направленность работы: повышение эффективности и результативности бюджетных расходов за счет совершенствования системы финансового планирования и внедрения новых механизмов бюджетного финансирования, обеспечения трансформации «планирования расходов» в «планирование результатов» деятельности функциональных учреждений.

Yakovenko D.A., Lykov V.A. Features of State (municipal) Order for Functional Organizations (by the example of sports organizations) / Yakovenko D.A., Lykov V.A.

Series "Administrative and budgetary reforms at the present stage»; Vol. 7Samara: National Institute of Professional Accountants, Financial Managers and Economists, 2010, p. 88 .

This methodological guide has been developed within the framework of the budgetary and administrative reforms carried out in the Russian Federation with regard to the implementation of budgeting and result-oriented management.

Purpose of the work: increasing efficiency and performance of budget expenditures by improving the system of financial planning and implementation of new mechanisms of budget financing, ensuring the transformation of "expenditure planning" into "results planning" in functional organizations. 


\section{Яковенко Д.А.}

Механизмы контроля внебюджетной деятельности (на примере функциональных учреждений спортивной отрасли) / Д.А. Яковенко, В.А. Лыков, М.Д. Яковенко. - Самара, Национальный ин-т проф. бухгалтеров, финансовых менеджеров и экономистов, 2010. - 55 с. - (Серия «Административная и бюджетная реформы на современном этапе»; Вып.8)

Настоящее методическое пособие подготовлено в рамках реализации бюджетной и административной реформ, проводимых в Российской Федерации в части внедрения бюджетирования и управления, ориентированных на результат.

Внедрение предложенных Авторами методологических подходов позволит:

- повысить эффективности управленческой деятельности Москомспорта в сфере контроля внебюджетной деятельности центров физической культуры и спорта административных округов;

- повысить контроль планирования и исполнения сметы доходов и расходов по внебюджетным средствам.

Монография рассчитана на руководителей органов государственной власти и местного самоуправления, преподавателей и студентов вузов.

Yakovenko D.A., Lykov V.A., Yakovenko M.D. Mechanisms of Control of Extrabudgetary Activities (by the example of functional organizations in the sports industry) / Yakovenko D.A., Lykov V.A., Yakovenko M.D.

Series "Administrative and budgetary reforms at the present stage"; Vol. 8 Samara: National Institute of Professional Accountants, Financial Managers and Economists, 2010, p. 55.

This methodological guide has been developed within the framework of the budgetary and administrative reforms carried out in the Russian Federation with regard to the implementation of budgeting and result-oriented management.

The implementation of the methodological approaches proposed by the Authors will allow achieving the following goals:

- Increase of management performance efficiency of the Moscow Sports Committee in control of non-budgetary activities of the centers of physical culture and sports in administrative districts;

- Improved control over planning and execution of the profit and loss estimate for extrabudgetary funds.

The monograph is designed for the heads of state authorities and local governments, teachers and students of universities. 


\section{Яковенко Д.А.}

Контроль за эффективным использованием бюджетных ресурсов в федеральных органах исполнительной власти / Д.А. Яковенко - Самара, Национальный ин-т проф. бухгалтеров, финансовых менеджеров и экономистов, 2021. - 285 с. (Серия «Административная и бюджетная реформы на современном этапе»; Вып.9) ISBN 978-5-94928-018-8

Ведомственный контроль является составной частью системы финансового менеджмента. Совершенствованием системы финансового менеджмента - системы управления государственными (общественными) финансами неизбежно ставит задачу совершенствования системы ведомственного финансового контроля. В результате проведенного исследования, выделены следующие особенности ведомственного финансового контроля в федеральных органах государственной власти:

- вектор контроля смещается с контроля за расходами на контроль за результатами, составной частью контроля при этом становится контроль за эффективностью расходования бюджетных средств.

В работе исследованы полномочия ФОИВ по осуществлению ведомственного финансового контроля и проблемы, связанные с законодательным регулированием процесса исполнения полномочий, исследованы специфические объекты контроля и особенности осуществления контроля в отношении различных объектов.

Проведенное исследование показывает, что имеющиеся недостатки в области нормативно-правового, методического и информационного обеспечения ведомственного финансового контроля снижают его эффективность. Результаты анализа показывают низкое качество правового обеспечения ведомственного финансового контроля.

Автором:

- уточнены методологические подходы к оценке эффективности ведомственного контроля за расходами бюджета. Это создает основу для повышения эффективности ведомственного финансового контроля.

- определены направления развития ведомственного контроля за расходами бюджета. Разработаны модельные нормативные акты по организации и функционированию системы ведомственного контроля.

\section{Yakovenko D.A. Control over the effective use of budgetary resources in federal executive bodies}

Series "Administrative and budgetary reforms at the present stage»; Vol. 9 Samara: National Institute of Professional Accountants, Financial Managers and Economists, 2021, p. 285.

Departmental control is an integral part of the financial management system.

Improvement of the financial management system - the system of management of state (public) finances inevitably brings the task of improving the system of departmental financial control. As a result of the study, the following features of departmental financial control in the federal government bodies are highlighted:

- The direction of control is shifting from expenditure control to results control, the control over the spending efficiency of budgetary funding becomes an integral part of the control.

The paper studies the powers of federal executive bodies in the implementation of departmental financial control and the problems associated with the legislative regulation of the process of exercising powers, the specific objects of control and features of control with respect to the various objects are investigated.

The study shows that the existing shortcomings of regulatory legislation, methodological and data support of departmental financial control reduce its effectiveness. The results of the analysis indicate the low quality of legal support of departmental financial control.

The author also carried out work in the following areas:

- The methodological approaches to assessing the effectiveness of departmental control over budget expenditures have been refined. This provides a basis for improving the effectiveness of departmental financial control.

- The directions of development of departmental control over budget expenditures have been determined. Model regulations on the organization and functioning of the 290 system of departmental control have been developed. 


\section{Яковенко Д.А.}

Контроль за эффективным использованием бюджетных ресурсов в федеральных органах исполнительной власти / Д.А. Яковенко - Самара, Национальный инт проф. бухгалтеров, финансовых менеджеров и экономистов, 2021. - 207 с. - Изд. второе, дополненное (Серия «Административная и бюджетная реформы на современном этапе»; Вып.9)

ISBN 978-5-94928-019-5

Yakovenko D.A. Control over the effective use of budgetary resources in federal executive bodies

Series "Administrative and budgetary reforms at the present stage»; Vol. 9 - Samara: National Institute of Professional Accountants, Financial Managers and Economists, second edition, revised, 2021, p. 207. 
Научное издание

Серия «Административная и бюджетная реформы на современном этапе» Выпуск 10

Яковенко Дмитрий Анатольевич

\title{
ОТДЕЛЬНЫЕ ВОПРОСЫ КОНТРОЛЯ В ЭКОЛОГИИ: ОПЫТ, ПРОБЛЕМЫ И ПЕРСПЕКТИВЫ
}

\author{
В авторской редакции
}

Ответственный за выпуск В.В.Хомутов

Компьютерная верстка В.В.Телегин

Сдано в набор 05.06.2021. Подписано в печать 15.07.2021.

Бумага офсетная. Формат 60х84/16. Гарнитура «Прагматика». Печать оперативная.

Усл.печ.л. 16,97. Уч. -изд.л. 17,34. Тираж 800 экз. Заказ № 98 Национальный институт профессиональных бухгалтеров, финансовых менеджеров и экономистов 443041, г.Самара, ул. Рабочая, д. 21а, оф. 2 